Silvia Regina Dowgan Tesseroli de Siqueira

\title{
Avaliação sensitiva quantitativa de doentes com dor orofacial
}

Tese apresentada ao Departamento de Neurologia da Faculdade de Medicina da Universidade de São Paulo para a obtenção do título de Livre Docente

São Paulo

2011 


\section{Dedicatória}

À minha família, em especial ao meu esposo Rogério, meu querido companheiro 


\section{Agradecimentos}

Ao Prof. Manoel Jacobsen Teixeira, por ser esse grande mestre que proporcionou inúmeras oportunidades para a realização dos meus projetos e publicações, em especial este trabalho;

Ao meu marido Rogério, grande incentivador de minha carreira, por todo o seu amor e pela família maravilhosa que nós temos;

Á minha filha Natália, mesmo que tão pequena, pela compreensão nas minhas ausências para dedicar-me ao meu trabalho;

Ao meu pai e professor, José Tadeu, que me ensinou o gosto pela Odontologia e pela pesquisa, e acima de tudo, valores éticos não só na minha profissão mas, também em minha vida pessoal;

À minha mãe, Irene, por seus conhecimentos em educação e pela base que me proporcionou ao longo de minha vida;

Ao meu irmão Márcio, mesmo que distante, sempre presente nos grandes acontecimentos familiares e profissionais;

Ao Dr. Senlis Landre Diogo pelo desenvolvimento da metodologia aqui utilizada, e que foi o início do laboratório de sensibilidade;

Ao Prof. Dr. Wilson Jacob Filho, por ter nos apoiado participando de parte desta pesquisa, relativa ao envelhecimento; 
Aos colegas da Equipe de Dor Orofacial e do Centro Interdisciplinar de Dor que contribuíram direta ou indiretamente para este trabalho, em especial Cláudio Marinho, Astrid Arap, Fábio Kurogi Alvarez, Mariana Siviero, Luciana Alvarenga da Silva, Maíra Caracas, Helena Kazyiama, Gerson Ballester, Rogério Adas;

A todos os funcionários e docentes da Divisão de Neurologia e Divisão de Odontologia do Instituto Central, da Divisão de Neurocirurgia do Instituto de Psiquiatria do Hospital das Clínicas e do Departamento de Neurologia da Faculdade de Medicina da Universidade de São Paulo, pois sem a sua participação nada disso poderia ter sido realizado;

A todos os indivíduos doentes e saudáveis que contribuíram para este trabalho, e também a todos aqueles que poderão se beneficiar dos conhecimentos aqui gerados;

À Fundação de Amparo à Pesquisa do Estado de São Paulo (FAPESP), pois através de seu apoio foi possível montar esse laboratório de pesquisa;

A Deus, por sua presença nos momentos difíceis e nas conquistas. 
Esta tese está de acordo com:

Referências: adaptado de International Comittee of Medical Journals Editors (Vancouver)

Universidade de São Paulo. Faculdade de Medicina. Serviço de Biblioteca e Documentação. Guia de apresentação de dissertações, teses e monografias. Elaborado por Anneliese Carneiro da Cunha, Maria Júlia de A. L. Freddi, Maria F. Crestana, Marinalva de Souza Aragão, Suely Campos Cardoso, Valéria Vilhena. São Paulo: Serviço de Biblioteca e Documentação: 2004.

Abreviaturas dos títulos dos periódicos de acordo com List of Journals Indexed in Index Medicus. 


\section{LISTA DE SIGLAS}

\begin{tabular}{|c|c|c|}
\hline AMPA & - & ácido alfa-amino-3-hidroxi-S-metil-4-isoxazole propiônico \\
\hline AMPc & - & adenosina monofosfato cíclico \\
\hline ATM & - & Articulação temporomandibular \\
\hline CAPPesq & - & $\begin{array}{l}\text { Comissão de Ética em Pesquisa do Hospital das Clínicas } \\
\text { da Faculdade de Medicina da Universidade de São Paulo }\end{array}$ \\
\hline $\mathrm{CC}$ & - & Cefaleia cervicogênica \\
\hline CGRP & - & peptídeo relacionado ao gene da calcitonina \\
\hline DFA & - & dor facial atípica \\
\hline DFIP & - & dor facial idiopática persistente \\
\hline DTM & - & disfunção temporomandibular \\
\hline EDOF-HC & - & Equipe de Dor Orofacial do Hospital das Clínicas da \\
\hline & & Faculdade de Medicina da Universidade de São Paulo \\
\hline EUA & - & Estados Unidos da América \\
\hline EVA & - & Escala visual analógica \\
\hline FAPESP & - & Fundação de Amparo à Pesquisa do Estado de São Paulo \\
\hline FMUSP & - & Faculdade de Medicina da Universidade de São Paulo \\
\hline GABA & - & ácido gama-aminobutírico \\
\hline GAMIA & - & Grupo de Assistência Multidisciplinar ao Idoso Ambulatorial \\
\hline GTP & - & guanosina trifosfato \\
\hline IASP & - & International Association for the Study of Pain \\
\hline $\mathrm{IP}_{3}$ & - & inositol trifosfato \\
\hline ND & - & neuropatia diabética \\
\hline NIT & - & neuralgia idiopática do trigêmeo \\
\hline NMDA & - & $\mathrm{N}$-metil-D-aspartato \\
\hline $\mathrm{NPH}$ & - & neuralgia pós-herpética \\
\hline NPT & - & neuropatia pós-traumática \\
\hline OMS & - & Organização Mundial de Saúde \\
\hline$S A B$ & - & Síndrome da ardência bucal \\
\hline S-I & - & córtex somatossensitivo primário \\
\hline S-II & - & córtex somatossensitivo secundário \\
\hline TSQ & - & Testes sensitivos quantitativos \\
\hline
\end{tabular}




\section{LISTA DE TABELAS}

Tabela 1 -

Tabela 2 -

Tabela 3 -

Tabela 4 -

Tabela 5 -

Tabela 6 -

Tabela 7 -

Tabela 8 -

Tabela 9 -

Tabela 10

Tabela 11 .

Tabela 12

Tabela 13 -

Tabela 14 -

Tabela 15

Tabela 16 -

Tabela 17 -

Características da amostra 1 de acordo com o diagnóstico $(\mathrm{N}=336)$

Características gerais da amostra 2 de acordo com o diagnóstico $(\mathrm{N}=123)$

Diferenças entre as amostras quanto às características gerais para cada diagnóstico $(\mathrm{N}=459)$

Características subjetivas faciais de sensibilidade: freqüências e intensidades de dormência e disestesia de acordo com a amostra estudada $(\mathrm{N}=459)$

Características subjetivas de sensibilidade: freqüências e intensidades de dormência e disestesia na região facial de acordo com os diagnósticos $(\mathrm{N}=459)$.

Avaliação do reflexo córneo-palpebral nos lados direito/afetado e esquerdo/controle: comparação entre os diagnósticos $(\mathrm{N}=459)$

Características de dor orofacial da amostra (queixa principal, períodos de dor, intensidade e duração): comparação entre os diagnósticos $(\mathrm{N}=123)$.

Características de dor orofacial da amostra (descritores espontâneos, fatores de melhora e de piora): comparação entre os diagnósticos $(\mathrm{N}=123)$.

Queixas de cefaleia, dor generalizada e qualidade do sono: comparação entre os diagnósticos $(\mathrm{N}=123)$.

Morbidades associadas: comparação entre os diagnósticos $(\mathrm{N}=123)$.

Características mandibulares e de mastigação (incômodo e lateralidade): comparação entre os diagnósticos $(\mathrm{N}=123)$.

Características mandibulares e de mastigação (qualidfade, abertura bucal e hábitos): comparação entre os diagnósticos $(\mathrm{N}=123)$

Queixas mandibulares da amostra: comparação entre os diagnósticos $(\mathrm{N}=123)$.

Queixas de mastigação da amostra: comparação entre os diagnósticos $(\mathrm{N}=123)$.

Características dentais ao exame clínico: comparação entre os diagnósticos $(\mathrm{N}=123)$.

Características mandibulares ao exame clínico: comparação entre os diagnósticos $(\mathrm{N}=123)$ 
Tabela 18 Queixas subjetivas de xerostomia (boca seca e dificuldade de mastigar ou falar): comparação entre os diagnósticos ( $\mathrm{N}=123)$

Tabela 19 - $\quad$ Fatores associados às queixas subjetivas de xerostomia (sede, beber líquidos e evitar alimentos): comparação entre os diagnósticos $(\mathrm{N}=123)$

Tabela 20 -

Queixas subjetivas de xerostomia e fatores associados (uso de balas/chicletes, mau hálito, mucosas e pele seca, ardor e copos diários de água): comparação entre os diagnósticos ( $\mathrm{N}=123)$

Tabela 21 -

Queixas subjetivas de xerostomia e fatores associados relacionados ao sistema digestivo: comparação entre os diagnósticos $(\mathrm{N}=123)$

Tabela 22 - Queixas subjetivas de xerostomia e fatores associados (saliva e paladar): comparação entre os diagnósticos $(\mathrm{N}=123)$. 


\section{LISTA DE FIGURAS}

Figura 1 -

Figura 2 -

Figura 3 -

Figura 4 -

Figura 5 -

Figura 6 -

Figura 7 -

Figura 8 -

Figura 9 -

Figura 10 -

Figura 11 -

Figura 12 -

Figura 13 -

Figura 14 -

Figura 15 -

Figura 16 -

Figura 17 -
Avaliação sensitiva quantitativa térmica (frio): comparação entre as amostras para cada ramo trigeminal $(\mathrm{N}=459)$.

Avaliação sensitiva quantitativa térmica (calor): comparação entre as amostras para cada ramo trigeminal $(\mathrm{N}=459)$

Avaliação sensitiva quantitativa mecânica táctil: comparação entre as amostras para cada ramo trigeminal $(\mathrm{N}=459)$....

Avaliação sensitiva quantitativa mecânica dolorosa: comparação entre as amostras para cada ramo trigeminal $(\mathrm{N}=459)$

Avaliação sensitiva quantitativa dolorosa de superfície: comparação entre as amostras para cada ramo trigeminal $(\mathrm{N}=459)$

Avaliação sensitiva quantitativa térmica (frio): comparação entre os diagnósticos para o ramo oftálmico $(\mathrm{N}=459)$

Avaliação sensitiva quantitativa térmica (frio): comparação entre os diagnósticos para o ramo maxilar $(\mathrm{N}=459)$

Avaliação sensitiva quantitativa térmica (frio): comparação entre os diagnósticos para o ramo mandibular $(\mathrm{N}=459)$

Avaliação sensitiva quantitativa térmica (calor): comparação entre os diagnósticos para o ramo oftálmico $(\mathrm{N}=459)$

Avaliação sensitiva quantitativa térmica (calor): comparação entre os diagnósticos para o ramo maxilar $(\mathrm{N}=459)$.

Avaliação sensitiva quantitativa térmica (calor): comparação entre os diagnósticos para o ramo mandibular $(\mathrm{N}=459)$

Avaliação sensitiva quantitativa mecânica táctil: comparação entre os diagnósticos para o ramo oftálmico $(\mathrm{N}=459)$

Avaliação sensitiva quantitativa mecânica táctil: comparação entre os diagnósticos para o ramo maxilar $(\mathrm{N}=459)$.

Avaliação sensitiva quantitativa mecânica táctil: comparação entre os diagnósticos para o ramo mandibular $(\mathrm{N}=459)$

Avaliação sensitiva quantitativa mecânica dolorosa: comparação entre os diagnósticos para o ramo oftálmico $(\mathrm{N}=459)$

Avaliação sensitiva quantitativa mecânica dolorosa: comparação entre os diagnósticos para o ramo maxilar $(\mathrm{N}=459)$.

Avaliação sensitiva quantitativa mecânica dolorosa: comparação entre os diagnósticos para o ramo mandibular $(\mathrm{N}=459)$ 
Figura 18 -

Avaliação sensitiva quantitativa dolorosa de superfície: comparação entre os diagnósticos para o ramo oftálmico $(\mathrm{N}=459)$

Figura 19 - Avaliação sensitiva quantitativa dolorosa de superfície: comparação entre os diagnósticos para o ramo maxilar $(\mathrm{N}=459)$.

Figura 20 -

Avaliação sensitiva quantitativa dolorosa de superfície: comparação entre os diagnósticos para o ramo mandibular $(\mathrm{N}=459)$

Figura 21 - $\quad$ Avaliação quantitativa gustativa (doce e salgado): comparação entre os diagnósticos $(\mathrm{N}=123)$.......

Figura 22 - $\quad$ Avaliação quantitativa gustativa (azedo e amargo): comparação entre os diagnósticos $(\mathrm{N}=123)$. .

Figura 23 -

Avaliação quantitativa olfativa: comparação entre os diagnósticos $(\mathrm{N}=123)$

Figura 24 -

Avaliação quantitativa gustativa: comparação entre as médias dos limiares gustativos (doce, salgado, azedo e amargo) entre os diagnósticos $(\mathrm{N}=123)$

Figura 25 - $\quad$ Avaliação sensitiva quantitativa térmica (frio): valores médios e comparação entre os diagnósticos $(\mathrm{N}=123)$.

Figura 26 - $\quad$ Avaliação sensitiva quantitativa térmica (calor): valores médios e comparação entre os diagnósticos $(\mathrm{N}=123)$....

Figura 27 - $\quad$ Avaliação sensitiva quantitativa mecânica táctil: valores médios e comparação entre os diagnósticos $(\mathrm{N}=123)$.....

Figura 28 - $\quad$ Avaliação sensitiva quantitativa mecânica vibratória: valores médios e comparação entre os diagnósticos $(\mathrm{N}=123)$

Figura 29 - Avaliação sensitiva quantitativa mecânica elétrica: valores médios e comparação entre os diagnósticos $(\mathrm{N}=123)$

Figura 30 - $\quad$ Avaliação sensitiva quantitativa dolorosa de profundidade: valores médios e comparação entre os diagnósticos $(\mathrm{N}=123)$. 100

Figura 31 - $\quad$ Avaliação sensitiva quantitativa dolorosa de superfície: valores médios e comparação entre os diagnósticos $(\mathrm{N}=123)$ 101

Figura 32 - $\quad$ Avaliação sensitiva quantitativa elétrica dental: valores médios e comparação entre os diagnósticos $(\mathrm{N}=123)$.....

Figura 33 - $\quad$ Avaliação sensitiva quantitativa térmica (frio): comparação entre os lados de acordo com o ramo trigeminal $(\mathrm{N}=123)$.

Figura 34 - $\quad$ Avaliação sensitiva quantitativa térmica (calor): comparação entre os lados de acordo com o ramo trigeminal $(N=123)$..... 105

Figura 35 - $\quad$ Avaliação sensitiva quantitativa mecânica táctil: comparação entre os lados de acordo com o ramo trigeminal $(\mathrm{N}=123)$. 106 
Figura 36 - $\quad$ Avaliação sensitiva quantitativa mecânica vibratória: comparação entre os lados de acordo com o ramo trigeminal $(\mathrm{N}=123)$.

Figura 37 - $\quad$ Avaliação sensitiva quantitativa mecânica elétrica: comparação entre os lados de acordo com o ramo trigeminal $(\mathrm{N}=123)$... 108

Figura 38 - $\quad$ Avaliação sensitiva quantitativa dolorosa de profundidade: comparação entre os lados de acordo com o local em face $(\mathrm{N}=123)$

Figura 39 - Avaliação sensitiva quantitativa dolorosa de superfície: comparação entre os lados de acordo com o ramo trigeminal $(\mathrm{N}=123)$

Figura 40 - $\quad$ Avaliação sensitiva quantitativa térmica (frio): comparação entre os lados de acordo com o local (mãos ou tíbia) $(\mathrm{N}=123)$

Figura 41 - $\quad$ Avaliação sensitiva quantitativa térmica (calor): comparação entre os lados de acordo com o local (mãos ou tíbia) $(\mathrm{N}=123)$.

Figura 42 - $\quad$ Avaliação sensitiva quantitativa mecânica táctil: comparação entre os lados de acordo com o local (mãos ou tíbia) $(\mathrm{N}=123)$.

Figura 43 - $\quad$ Avaliação sensitiva quantitativa mecânica vibratória: comparação entre os lados de acordo com o local (mãos ou tíbia) $(\mathrm{N}=123)$.

Figura 44 - $\quad$ Avaliação sensitiva quantitativa mecânica elétrica: comparação entre os lados de acordo com o local (mãos ou tíbia) $(\mathrm{N}=123)$.

Figura 45 -

Avaliação sensitiva quantitativa dolorosa de profundidade: comparação entre os lados de acordo com o local (mãos ou tíbia) $(\mathrm{N}=123)$

Figura 46 - Avaliação sensitiva quantitativa dolorosa de superfície: comparação entre os lados de acordo com o local (mãos ou tíbia) $(\mathrm{N}=123)$

Figura 47 - $\quad$ quantitativa de fluxo salivar: comparação entre os diagnósticos $(\mathrm{N}=123)$ 


\section{RESUMO}

Siqueira SRDT. Avaliação sensitiva quantitativa de doentes com dor orofacial. [Tese]. São Paulo: Faculdade de Medicina, Universidade São Paulo; 2011.

A dor orofacial é predominantemente mediada pelo sistema trigeminal, e pode levar a anormalidades sensitivas somestésicas, gustativas e olfativas. Este estudo teve por objetivos apresentar e comparar duas metodologias de avaliação de sensibilidade orofacial, avaliar uma amostra de doentes quanto à sensibilidade e correlacionar os achados com as características de dor orofacial, fluxo salivar e queixas de boca seca. Foram avaliados 459 indivíduos consecutivos, no período de Março de 2003 a Dezembro de 2009, sendo que 364 apresentavam dor orofacial e 95 eram indivíduos saudáveis. Desses, 336 foram avaliados através de metodologia desenvolvida pela Divisão de Neurocirurgia Funcional do Instituto de Psiquiatria do Hospital das Clínicas e Departamento de Neurologia da Faculdade de Medicina da Universidade de São Paulo (Amostra 1), e 123 foram avaliados através de metodologia internacionalmente utilizada (Amostra 2). Os exames incluíram a avaliação térmica (frio e calor), mecânica táctil, vibratória, elétrica, dolorosa de profundidade, dolorosa de superfície, gustativa e olfativa; a amostra 2 foi também avaliada através do questionário de dor da Equipe de Dor Orofacial, questionário de xerostomia e avaliação de fluxo salivar. Os dados foram tabulados e analisados estatisticamente. Dormência esteve presente inclusive nos controles $(48,4 \%)$ e em doentes com diagnóstico não neuropático, como disfunção temporomandibular (86,6\%); anormalidades sensitivas foram comuns principalmente na neuralgia pós-herpética e síndrome da ardência bucal ( $p<0,001)$; na neuralgia idiopática do trigêmeo, houve maior frequência de anormalidades tácteis no ramo mandibular $(p=0,009)$; os doentes apresentaram limiares gustativos menores do que os controles, exceto na fibromialgia, onde os limiares foram maiores $(p<0,001)$. As variáveis de boca seca, cefaleia, e intensidades de dor, de dormência e de disestesia estiveram relacionadas com anormalidades sensitivas como redução de paladar $(p=0,028)$, paladar alterado $(p=0,003)$, gosto fantasma $(p<0,001)$ e queimação oral $(p<0,001)$, sendo que quanto mais queixas subjetivas de paladar alterado ou gosto fantasma, maiores foram os limiares dolorosos de profundidade $(p=0,002)$. Não houve diferença estatística no fluxo salivar ou nos limiares olfativos. Este foi um dos primeiros estudos que investigou uma grande amostra de dor orofacial com testes sensitivos quantitativos; concluiu-se que a metodologia desenvolvida pode ser uma ferramenta importante para a avaliação da sensibilidade orofacial. Os limiares sensitivos foram variáveis entre as doenças e associados às características da dor orofacial e queixas de boca seca.

Descritores: dor orofacial, neuralgia do trigêmeo, síndrome da disfunção da articulação temporomandibular, sensibilidade térmica, percepção gustatória, olfação, xerostomia. 


\section{SUMMARY}

Siqueira SRDT. Quantitative sensory testing of patients with orofacial pain. [Thesis]. São Paulo: Faculdade de Medicina, Universidade São Paulo; 2011.

Orofacial pain is predominately mediated by the trigeminal system, and can produce somatosensory, gustative and olfactory abnormalities. The objectives of this study were to present and compare two methodologies of quantitative sensory testing, to evaluate a sample of patients in regard to the sensory findings and to correlate these findings with orofacial pain characteristics, salivary flow and dry mouth complaints. Four hundred and fifty nine consecutive patients were evaluated in the period from March 2003 to December 2009; among them, 364 had orofacial pain and 95 were healthy subjects; 336 were evaluated by the methodology developed in the Functional Neurosurgery Division of the Psychiatry Institute, Hospital das Clinicas and Neurology Department, Medical School, University of Sao Paulo (Sample 1) and 123 were evaluated by an international methodology (Sample 2). The thermal (cold and warm), tactile, vibratory, electric, gustative, olfactory and deep and superficial pain thresholds were investigated; sample 2 was also evaluated through the pain questionnaire of the Orofacial Pain Team, xerostomia questionnaire and salivary flow measurement. Data were tabled and statistically analyzed. Numbness was also reported by controls $(48.4 \%)$ and in patients with non neuropathic disorder diagnosis, such as temporomandibular disorder (86.6\%); sensory abnormalities were more frequent in post herpetic neuralgia and burning mouth syndrome $(p<0.001)$; idiopathic trigeminal neuralgia patients had the highest thresholds in the mandibular branch $(p=0.009)$. The patients had lower gustative thresholds than the controls, except for fibromyalgia $(p<0.001)$, and xerostomia, headache, pain intensity, numbness and dysesthesia were associated to loss of taste $(p=0.028)$, abnormal taste $(p=0.003)$, phantom taste $(p<0.001)$ and burning mouth $(p<0.001)$. There were no statistical differences in salivary flow and olfactory thresholds. In conclusion, this was one of the first studies to investigate a large sample of orofacial pain with quantitative sensory testing; the methodology developed can be an important tool for the orofacial sensitivity evaluation; the sensory thresholds of the evaluated disorders were not homogeneous, and the characteristics of orofacial pain and dry mouth complaints were associated with the sensory testing.

Descriptors: Orofacial pain, Trigeminal neuralgia, temporomandibular joint dysfunction syndrome, Temperature sense, taste perception. Olfaction. Xerostomia. 


\section{SUMÁRIO}

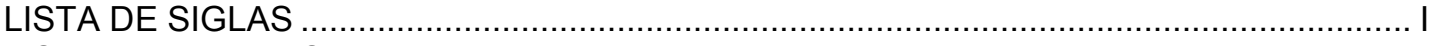

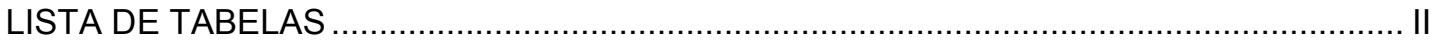

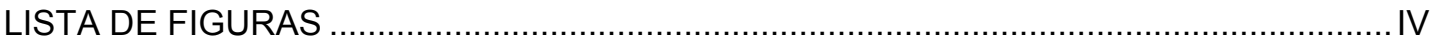

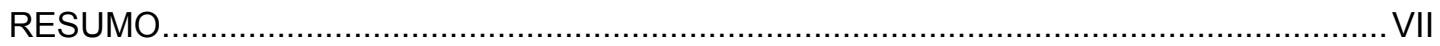

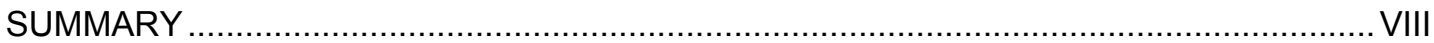

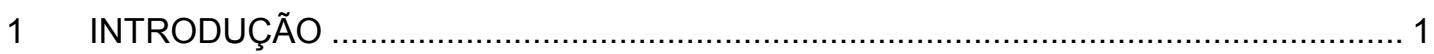

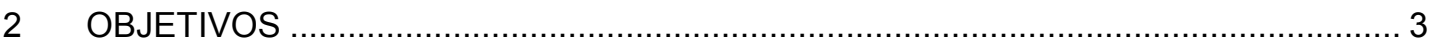

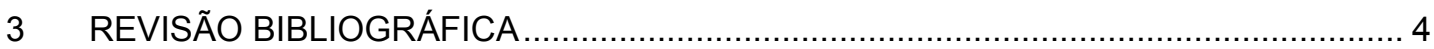

3.1 Dor orofacial: classificação, epidemiologia e fisiopatologia ............................... 4

3.2 Percepção sensitiva craniana: da transdução à consciência ............................ 11

3.3 Sistema somestésico trigeminal: tato, temperatura e dor .............................. 16

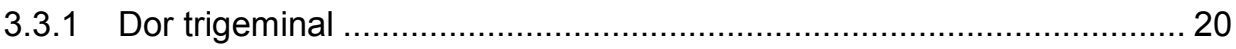

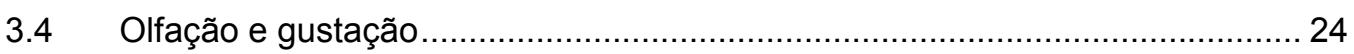

3.5 Integração da informação sensitiva orofacial .............................................. 31

3.6 Metodologia de avaliação sensitiva em dor orofacial..................................... 38

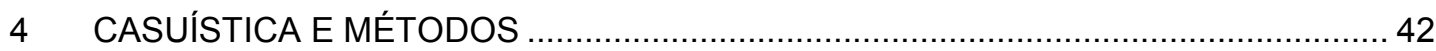

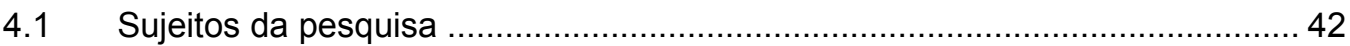

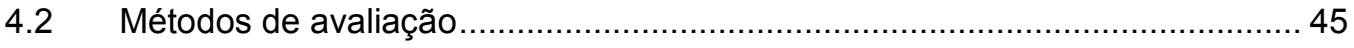

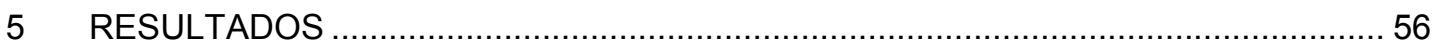

5.1 Comparação demográfica e sensitiva entre as amostras, de

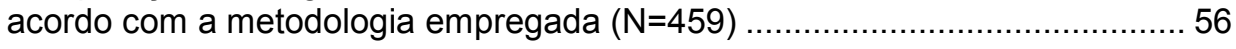

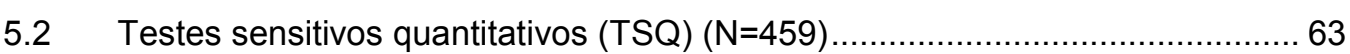

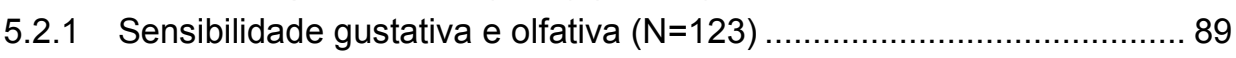

5.2.2 Sensibilidade somestésica trigeminal em doentes com dor orofacial comparados a controles: limiares

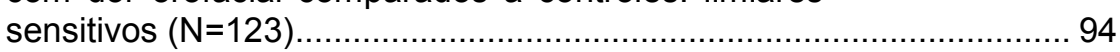

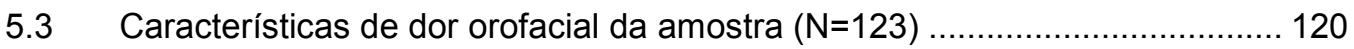

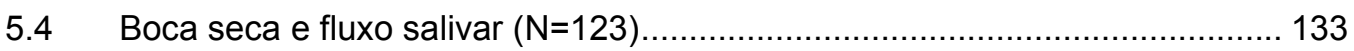

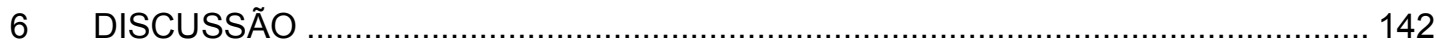

6.1 Testes sensitivos quantitativos (TSQ): avaliação
somestésica térmica, táctil e dolorosa ( $N=459)$

6.2 Testes sensitivos quantitativos (TSQ): avaliação somestésica vibratória e elétrica, gustativa e olfativa:

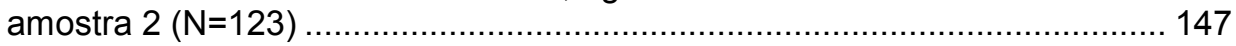

6.3 Avaliação de sensibilidade e correlações com a dor orofacial, queixas de boca seca e fluxo salivar. 


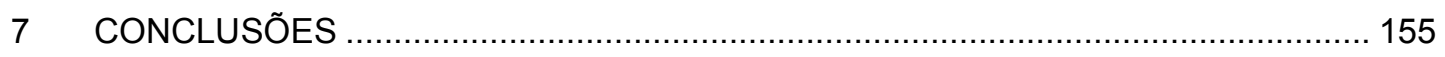

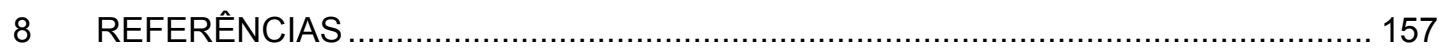

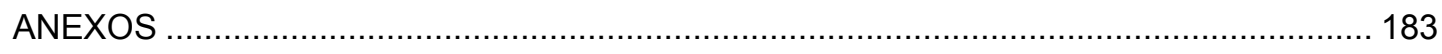

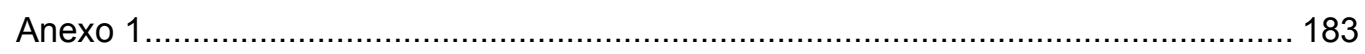

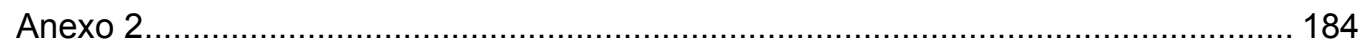

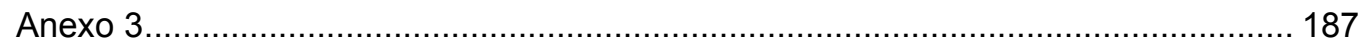




\section{INTRODUÇÃO}

A dor orofacial é mediada predominantemente pelo sistema trigeminal, que corresponde à maior área de integração de informações do corpo humano. Além de ser o maior nervo sensitivo, sua localização no segmento cefálico faz com que haja interações com outras sensações, provenientes dos mesmos tecidos por ele inervados, como a língua, parte do conduto auditivo, a cavidade nasal e a superfície ocular. Essas regiões são também inervadas por outros nervos cranianos e apresentam sensibilidades especiais: o paladar, a audição, o olfato e a visão, respectivamente.

A alimentação pode exemplificar a interação que ocorre nas percepções orofaciais. Ao visualizar o alimento, em conjunto ou não com a percepção do odor, há a estimulação da produção de saliva assim como ativação das musculaturas facial e mastigatória. Por outro lado, são os membros superiores os responsáveis pelos movimentos de levar o alimento à boca, e esta pode ser a razão da proximidade das áreas de representação nos córtex sensitivo e motor dessas duas regiões. É a percepção proprioceptiva e táctil do terço inferior da face que coordena os movimentos mastigatórios, entrando em um estado de automatização. Além disso, a saliva apresenta um papel importante na transdução nervosa intraoral. Nesse momento, a consciência se prende na percepção mista de textura, temperatura, paladar e olfato, que geram o sabor final do alimento. $\mathrm{O}$ paladar não pode ser restringido apenas à percepção isolada da língua quanto aos quatro sabores. A variação na proporção de intensidade de 
temperatura, concentração de íons sódio, cloro, hidrogênio, moléculas de açúcares, mais de 300 tipos de possibilidades de percepção olfativa, além da viscosidade, textura e outras características tácteis é o que se percebe como paladar.

Sendo assim, dada a complexidade do sistema trigeminal, não é incomum a região por ele inervada apresentar condições álgicas, e anormalidades sensitivas, como as dolorosas, que podem causar alterações em outras percepções sensitivas cefálicas. Sabe-se que essas alterações são mais comuns na dor neuropática, porém pouco se sabe sobre doentes com dor de outras etiologias, e poucas são as metodologias disponíveis para a investigação dessa região. Essas informações podem contribuir para a compreensão da fisiopatologia dessas doenças além de melhorar o entendimento de como ocorre a interação sensitiva neste complexo segmento. 


\section{OBJETIVOS}

Este estudo teve por objetivos:

1. Apresentar e comparar duas metodologias de avaliação sensitiva quantitativa (TSQ) para a região orofacial;

2. Avaliar uma amostra de doentes com dor orofacial quanto à sensibilidade somestésica trigeminal, gustativa e olfativa através desses testes;

3. Apresentar as características de dor orofacial, fluxo salivar e queixas de boca seca desses indivíduos, associá-las e correlacioná-las aos resultados de sensibilidade obtidos. 


\section{REVISÃO BIBLIOGRÁFICA}

\subsection{Dor orofacial: classificação, epidemiologia e fisiopatologia}

A dor tem importante função de alerta, e quando ausente, como no caso da insensibilidade congênita, leva a lesões graves e até à morte (Siqueira et al., 2006b). Trata-se de uma das sensações mais primitivas de caráter protetor (Teixeira et al., 2003), e suas sensações incluem formigamento, queimadura, dor, picada e irritação (Teixeira, 1995), geralmente acompanhadas de uma emoção desagradável, o que leva a um comportamento de evitação. Ela é definida pela Associação Internacional para o Estudo da Dor (International Association for the Study of Pain - IASP) como: "uma experiência emocional e sensitiva desagradável, associada à lesão real, em potencial ou descrita em tais termos". É importante diferenciar dor de nocicepção, já que a dor inclui a experiência e as emoções envolvidas na nocicepção. Sua natureza subjetiva é o que dificulta a sua definição e seu tratamento. Sabe-se que não há estímulos estritamente dolorosos e que um mesmo estímulo pode ou não desencadear dor em um determinado indivíduo (Basbaum e Jessell, 2003). A dor pode ser principalmente nociceptiva, resultado da ativação direta de nociceptores nos tecidos em resposta à lesão tecidual e geralmente acompanhada de inflamação, ou neuropática, ou seja, resultante de lesão direta ou disfunção 
do tecido nervoso periférico ou central (Teixeira, 1995; Basbaum e Jessell, 2003).

Além de ser uma das modalidades sensitivas somestésicas, a dor é uma queixa importante e motivo frequente de procura por atendimento médico e odontológico. Dor aguda é aquela com duração menor do que um mês, a subaguda dura de um a seis meses, e a crônica dura mais de seis meses (Merskey e Bogduk, 1994). Dor crônica também pode ser conceituada como a que persiste além da resolução da lesão que a causou (Bonica, 1953). A dor crônica é bastante prevalente na população mundial em geral, acometendo de $9 \%$ a $63,5 \%$ dos adultos e idosos (Von Korff et al., 1988; Nickel e Raspe, 2001; Watkins et al., 2008). No Brasil, há evidências de que a lombalgia é a afecção dolorosa mais prevalente $(65,9 \%)$, sendo seguida pela cefaleia tipo tensão $(60,2 \%)$ (Teixeira et al., 1994; Dellaroza et al., 2007).

Os indivíduos com dor crônica acarretam elevados custos diretos e indiretos, já que levam um grande período para concluir o diagnóstico e o tratamento, resultando em um elevado impacto econômico à sociedade (Chen et al., 2007; Ferreira et al., 2006; Ferreira et al., 2008). Este impacto é caracterizado por perdas de dias de trabalho, aposentadorias precoces, frequente procura por atendimento em serviços de saúde e gastos com tratamentos (Fortner et al., 2003; Mcdermott et al., 2006; Stewart et al., 2007). No Brasil, mais de $1 / 3$ da população julga que a dor crônica compromete as atividades habituais e mais de $3 / 4$ considera que a dor 
crônica é limitante para as atividades recreacionais e relações sociais e familiares (Teixeira, 1995; Teixeira e Pimenta, 1994; Ferreira et al., 2008).

Dez a $40 \%$ dos indivíduos apresentam dor com duração superior a um dia, pelo menos uma vez por ano (Von Korff et al., 1988; Von Korff et al., 1990; James et al., 1991). Na população brasileira, 2,7\% apresentaram sete ou mais dias de dor incapacitante para a execução de atividades habituais, durante os seis meses que precederam as entrevistas (Teixeira et al., 1999). Em até $2 / 3$ dos casos, a dor crônica geralmente localiza-se na região lombar e nas articulações e, 1/4 dos indivíduos no segmento cefálico (Croft et al., 1993). Dor é o sintoma mais frequentemente reportado pelos idosos, presente em mais de $50 \%$ de suas queixas, sendo que $19 \%$ dos idosos internados apresentam dor moderada a grave (IASP, 2006).

Dor no segmento cefálico ocorre, em algum momento da vida, em mais de 70\% das pessoas (Teixeira et al., 1994; Siqueira e Teixeira, 2001). Na Divisão de Neurologia do Hospital das Clínicas 97,1\% dos indivíduos apresentaram cefaleia (Rabello, 2000), porém no Brasil, são frequentemente mal diagnosticadas (Teixeira et al., 1999). Também são comuns as cefaleias secundárias como as dores orofaciais, e dentre elas as de origem dentária e as disfunções temporomandibulares (DTM) são as mais frequentes (Dworkin e LeResche, 1992; Siqueira et al., 2008). A dor de dente pode ser caracterizada como a dor que emana dos dentes e suas estruturas de suporte. É resultado de doenças como: cárie dentária, trauma ou doença periodontal (Siqueira e Ching, 1997; Siqueira, 2001). Quanto à sua origem, podem ser classificadas como odontogênicas e não-odontogênicas (Doreyat 
e Jaafar, 1998). A dor de dente odontogênica é frequentemente inflamatória e causa intensa sensibilização secundária (Sessle, 2000; Siqueira e Ching, 2001; Siqueira et al., 2004a); sua prevalência em escolares brasileiros com 14 a 15 anos foi descrita como $33,6 \%$ e 12,8\%, respectivamente (Goes, 2001). Dentre as dores não-odontogênicas, destacam-se as de caráter neuropático. As DTM representam um termo coletivo relacionado a vários problemas clínicos envolvendo a musculatura mastigatória, a articulação temporomandibular (ATM) ou ambas as estruturas (Dworkin e LeReshe, 1992; Oliveira et al., 2008; de Leeww, 2008). As DTM raramente apresentam-se como entidade única; frequentemente há superposição de sintomas e as etiologias são multifatoriais. Elas, na maior parte, encontramse associadas a outras síndromes álgicas faciais, inclusive de origem neuropática (Siqueira et al., 2007). Entre estas, a neuralgia idiopática do trigêmeo (NIT), neuralgia pós-herpética (NPH), síndrome da ardência bucal (SAB), neuropatias pós-traumáticas (NPT) entre outras, são frequentemente diagnosticadas.

A NIT é caracterizada por dor paroxística descrita frequentemente em choque, excruciante, acompanhada de intervalos entre as crises, e que apresenta comumente uma zona de gatilho responsável pelo disparo da dor (Teixeira, 1984). Acomete cerca de 4 a 5 indivíduos em cada 100.000, mais frequentemente mulheres, com média de idade de 60 anos (Katusic et al., 1990). Sua fisiopatologia ainda não se encontra totalmente esclarecida. Sabe-se que boa parte dos casos apresenta compressão da raiz trigeminal por um vaso sanguíneo (Teixeira, 1984; Teixeira, 1998). Canais de sódio 
voltagem dependentes parecem estar envolvidos (Siqueira et al., 2009). Seu tratamento inicial é através de anticonvulsivantes, mas com o tempo, neurocirurgia é necessária para o controle das crises (Teixeira et al., 2006; Siqueira e Teixeira, 2003; Siqueira e Siqueira, 2003, Siqueira et al., 2004b, Teixeira, 1991; Teixeira, 1998). Muitas anormalidades sensitivas e motoras mastigatórias podem ocorrer devido à cirurgia (Teixeira, 1984; Siqueira et al., 2006a; Siqueira et al., 2007).

A SAB é a queixa de queimação ou ardor bucal, geralmente constante, na ausência de causas primárias que justifiquem o desconforto (Nasri et al., 2000; Nasri et al, 2007). Sua prevalência é de $0,7 \%$ a $18 \%$ da população adulta (Hakeberg et al., 1997), sendo que os indivíduos mais afetados apresentam idade entre 45 e 60 anos. A SAB afeta mais comumente as mulheres, quando comparadas aos homens, em proporções que vão desde 3:1 até 16:1 (Lamey, 1996). Sua etiologia é idiopática, e as evidências atuais classificam-na como uma doença neuropática. Acredita-se que ocorra uma desinibição do sistema trigeminal através de anormalidades primárias gustativas mediadas pelo nervo corda do tímpano (Grushka e Sessle, 1988; Grushka et al., 2006), ou ainda, que haja lesão neuropática trigeminal primária, gerando anormalidades gustativas e olfativas no sistema nervoso central (Siviero et al., 2011a).

A NPH é caracterizada pela persistência da dor no território de acometimento da infecção pelo vírus Herpes zoster, por um período maior do que três meses, sendo que o ramo oftálmico do nervo trigêmeo, responsável por $15 \%$ a $20 \%$ dos casos, é o segundo local mais afetado, 
depois da região torácica (Peterson e Rowbotham, 2010; Teixeira e Okada, 1999). A dor crônica característica da NPH pode ser acompanhada por parestesia, hiperestesia, alodínia e alterações sensitivas. Acredita-se que anormalidades subclínicas possam ocorrer em regiões do lado contralateral e, também, em ramos adjacentes não afetados visualmente pela infecção (Alvarez et al., 2007).

Outras dores neuropáticas que frequentemente ocorrem no segmento cefalico são a NPT, decorrente de lesão nervosa, caracterizadas por dor devido à desaferentação, e neuropatias relacionadas a doenças sistêmicas, como a neuropatia diabética (ND), em que anormalidades subclínicas sensitivas trigeminais podem estar presentes (Arap et al., 2010). A fibromialgia também é condição sistêmica que pode causar alterações sensitivas, porém, não há estudos da região orofacial, e anormalidades neurológicas, como a Síndrome de Wallemberg (SW) ou a paralisia facial (PF), também podem resultar em dor neuropática (Siqueira e Teixeira, 2001).

Independentemente da etiologia da dor orofacial, o sistema mastigatório frequentemente é afetado e, assim, pode haver sobreposição de sintomas (Siqueira et al., 2007). Além disso, pode haver síndrome dolorosa miofascial na região cervical associada, e dor referida à região orofacial e / ou craniana pode estar presente, caracterizando a cefaleia cervicogênica (CC) (Siqueira e Teixeira, 2001; International Headache Society Classification, 2004). 
$\mathrm{Na}$ avaliação do doente, o comportamento e características emocionais devem também ser considerados. Sabe-se que doentes com NIT apresentam comportamento menos catastrófico do que doentes com DTM, mesmo tendo uma dor mais intensa, podendo ser, porém, mais manejável (Castro et al., 2008; Oliveira et al., 2008; Castro et al., 2009). Dores dentárias como as cáries e doença periodontal podem associar-se a outras causas, determinando maior complexidade e dificultando o diagnóstico (Fabri et al., 2009). Por estas razões, muitos deles acabam por ser identificados como condições de exclusão, como a dor facial atípica (DFA) (Prado, 2002; Nóbrega et al., 2007), diagnóstico atualmente denominado por dor facial idiopática persistente (DFIP) (International Headache Society Classification, 2004). Sendo assim, a avaliação completa da região orofacial e a análise da história do doente são cruciais para o diagnóstico correto. Diante do fato de que muito da fisiopatologia necessita ainda de esclarecimentos, a investigação sensitiva não só somestésica mas, também, gustativa e olfativa pode contribuir para a identificação dos fatores envolvidos (Siqueira et al., 2006a). A avaliação sensitiva permite observar a presença de dor de caráter neuropático, hiperalgesia secundária e sensibilização central, fenômenos relacionados intimamente com neuroplasticidade (Teixeira, 1995; Sessle, 2000). 


\subsection{Percepção sensitiva craniana: da transdução à consciência}

A percepção sensitiva craniana envolve informações mediadas pelos nervos: olfatório (I par), óptico (II par), trigêmeo (V par), facial (VII par), vestibulococlear (VIII par), glossofaríngeo (IX par) e vago (X par) (Gottlieb, 1970). Todas as informações percebidas do ambiente compartilham princípios básicos de processamento, que passa pela transformação do estímulo em impulso elétrico, pela modulação e pela percepção consciente, o que gera uma resposta. Há quatro características sensitivas que são: modalidade, localização, intensidade e duração (Valbo et al., 1979; Dudel, 1983). A modalidade foi proposta em Muller em 1826 e é a classe do estímulo (ex: paladar e seus subtipos: doce, azedo, salgado, amargo; tato e seus subtipos: discriminativo, pressão, rigidez, textura), determinada geralmente por um receptor específico; a localização é a habilidade do receptor em reconhecer a parte do corpo onde ocorreu o estímulo; a intensidade e duração estão relacionadas à amplitude do estímulo e ao tempo de aplicação (Gardner e Martin, 2003). A sensibilidade a um estímulo é específica para o tipo de informação, seja ela táctil, térmica, dolorosa, etc., e obedece a um código de identificação linear. Toda sensibilidade depende de experiência prévia que é aprendida de forma única, dependendo da contextualização. Cores, sons e sabores são apenas criações mentais produzidas no encéfalo pela experiência sensitiva e não são registros diretos do mundo exterior (Sherrington, 1947; Savage, 1970). 
Existem quatro classes de receptores, sensíveis primariamente a uma forma diferente de energia: mecânicos, químicos, térmicos ou eletromagnéticos. Os estímulos mecânicos estão relacionados ao tato, propriocepção, audição e dor; os quimoceptores à dor, prurido, gustação, olfação; os termoceptores à dor e temperatura; e os eletromagnéticos à visão (Valbo et al., 1979; Corey e Roper, 1992). Os mecanoceptores ativam fisicamente canais de cátions transmembranares ligados ao citoesqueleto neuronal, que abrem canais voltagem dependentes que desencadeiam despolarização (Montcastle et al., 1966; Hensel, 1973; Gardner e Martin, 2003). Os quimioceptores e fotoceptores agem pela ativação de segundos mensageiros através de proteína G, que produzem despolarização (quimioceptores) ou hiperpolarização (visão) (Tanner e Swets, 1954).

estímulo inicial é amplificado e, assim, pequenas quantidades de estímulo podem ser percebidas (Gardner e Martin, 2003).

A distribuição dos receptores ativados fornece informações importantes e específicas sobre a localização espacial, tamanho e forma, e resolução de detalhes; essas habilidades estão ligadas ao campo receptor, ou seja, que determina a localização topográfica específica da informação sensitiva (Dudel, 1983; Corey e Roper, 1992). A densidade de receptores em cada região do corpo determina a quantidade de detalhes; quanto maior a densidade, como no caso das mãos e da boca, maior essa definição. Já os receptores de olfato e paladar estão distribuídos de acordo com o espectro de energia da modalidade, e no caso da audição, de acordo com a frequência. A percepção de diferentes intensidades é importante para 
diferenciar dois estímulos em que a magnitude é a diferença entre eles (Gardner e Martin, 2003). Essa responde segundo a Lei de Weber, $\Delta S=K x$ $\mathrm{S}$, onde $\Delta \mathrm{S}$ é a diferença mínima na força entre um estímulo de referência $\mathrm{S}$ e um segundo estímulo que pode ser discriminado, e K é uma constante chamada de diferença notável. Fechner expandiu a Lei de Weber em 1860 para descrever a relação entre a força do estímulo ou intensidade (S) e a intensidade da sensação propriamente dita experimentada pelo indivíduo: I=K log $\mathrm{S} / \mathrm{S}_{0}$ (sendo $\mathrm{S}_{0}$ a amplitude limiar do estímulo). Em 1953, Stanley Stevens percebeu que numa extensa faixa de estimulação a intensidade é melhor descrita por uma função exponencial do que logarítmica, e chegou à formula: I=K (S- S $)^{\mathrm{n}}($ Dudel, 1983).

A menor força de um estímulo que o indivíduo é capaz de perceber é chamada de limiar sensitivo. Os limiares podem ser alterados devido a problemas no receptor, nos aferentes primários ou no processamento central (Valbo et al., 1979). Também, podem ser modulados por aspectos emocionais ou ambientais. Identificar um estímulo depende da percepção propriamente dita e do julgamento do indivíduo de ter realmente percebido este estímulo (Gardner e Martin, 2003). Em 1920, Edgar Adrian e Yngve Zotterman notaram que a frequência de descarga de uma fibra aferente cresce conforme o aumento de intensidade do estímulo. Imediatamente após um potencial de ação existe um período refratário de 0,8 a 1,0 ms. Com a inatividade dos canais de sódio nesse período, não é possível desencadear potenciais de ação. Quanto maior o estímulo, mais disparos ocorrerão pela maior amplitude do impulso e, também, neurônios 
vizinhos serão ativados. Assim, a quantidade de neurônios ativados também está relacionada com a percepção de intensidade. Se o estímulo persistir na mesma intensidade por um período de minutos, a percepção irá diminuir e ocorrerá o fenômeno de adaptação. A adaptação por receptores lentos ocorre pela lenta inativação de canais de sódio e cálcio ou como resultado da ativação de canais de potássio dependentes de cálcio (Dudel, 1983; Gardner e Martin, 2003). Receptores de adaptação rápida respondem a alterações cinéticas de velocidade e movimento, ou seja, disparam quando o estímulo muda de posição. Estes apresentam longa inativação dos canais e longo período de refração e / ou filtram a manutenção estável do estímulo (Corey e Roper, 1992).

É importante salientar que as mensagens dos receptores individuais são integradas e não meramente somadas quando chegam aos centros de processamento. As informações são inicialmente processadas em vias paralelas e posteriormente integradas e centros superiores (Sherrington, 1947). Cada neurônio de primeira ordem recebe uma porção de conexões de diversos receptores, o mesmo ocorre entre os neurônios de segunda ordem e os de terceira ordem. Os primeiros, próximos ao local de processamento, definem quais as informações serão transmitidas ao córtex e separam o ruído esporádico de fibras individuais. Existem interneurônios inibitórios nos sistemas superiores que colaboram na seleção da informação de maneira integrada (Sherrington, 1947; Savage, 1970). Neurônios menos ativos são inibidos frente a neurônios mais ativos e, assim, a informação mais constante é a que passa; as vias superiores podem também enviar 
sinais inibit órios descendentes e controlar o impulso da sensação (Gardner e Martin, 2003).

Os aferentes primários sensitivos convergem para os núcleos no tronco encefálico de onde sai um segundo neurônio em direção ao tálamo, e posteriormente ao córtex onde então o sinal passa a ser percebido conscientemente. As informações sensitivas dos nervos cranianos penetram no sistema nervoso central e distribuem-se basicamente em três regiões: nos núcleos trigeminais (informações somestésicas da face), no núcleo solitário (informações gustativas) e no núcleo coclear (informações auditivas). As informações visuais e olfativas seguem através de outras vias que não as do tronco encefálico. Também, nesta região, encontra-se a formação reticular, que parece controlar a informação aferente sensitiva que deve atingir ou não níveis mais altos do sistema nervoso central, como é o caso da percepção do contato das roupas ao corpo, participando do sistema supressor descendente de dor (Melzack e Wall, 1965; Crossman e Neary, 2002). Sabe-se que as células da glia, também, estão envolvidas em fenômenos relacionados com a condução nervosa, como na neuroplasticidade e formação de memória e comportamentos (Sherrington, 1947; Gardner e Martin, 2003).

O mapa cortical que corresponde aos dermatômeros espinais definidos por vias ascendentes apresenta a representação trigeminal em sua porção mais lateral (Montcastle, 1995). A resolução espacial no córtex está relacionada à densidade de inervação da pele; as áreas mais inervadas e, portanto, mais representadas, são a mão, o pé e a boca. Essas áreas de 
representatividade não são fixas e podem se modificar de acordo com a experiência (Mountcastle, 1997). A resolução espacial de uma informação sensitiva ocorre devido à inibição periférica de informações, evitando a sua propagação para áreas adjacentes. Essa mesma inibição é responsável pela diferenciação entre dois pontos distintos (Gardner e Kandel. 2003).

\subsection{Sistema somestésico trigeminal: tato, temperatura e dor}

Dentre os sistemas sensitivos, o sistema somestésico foi o primeiro a ser investigado quanto à percepção e integração da informação. Dentre suas funções, além da percepção táctil, térmica e dolorosa isoladas, há funções integradas complexas como a estereognosia, que é a capacidade de identificação de um objeto envolvendo, além das aferências, processos cognitivos cerebrais (Gardner e Kandel, 2003). As diversas partes de um objeto são percebidas por muitos campos receptores distintos, porém é o encéfalo que reconstitui e integra todas as informações recebidas na identificação desse objeto (Favorov e Kelly, 1994). Até informações distantes, como a postura do corpo com relação ao objeto analisado, participam do compartilhamento de dados para determinação da posição que o objeto se encontra (Gardner et al., 1989).

A sensibilidade somestésica facial é principalmente mediada pelo nervo trigêmeo, V par craniano, dividido em seus três ramos: oftálmico, maxilar e mandibular. Este nervo é responsável pela percepção somestésica da face, mucosa oral, mucosa nasal, córnea, dentes, gengivas, duramáter, e 
suas informações convergem para os núcleos trigeminais localizados no tronco encefálico (Sessle, 2000). Trata-se do maior complexo nuclear sensitivo do corpo, sendo que a porção mais caudal destes núcleos estendese em continuidade com o corno posterior da medula espinal, que recebe a informação sensitiva das outras partes do corpo humano (Crossman e Neary, 2002). Além deste nervo, também possuem aferências somestésicas os nervos glossofaríngeo (porção posterior da língua, faringe), vago (porção caudal da faringe, laringe) e alguns ramos do nervo facial relacionados à percepção somestésica do conduto auditivo (Sessle, 2000).

Dentre as modalidades de percepção, a sensibilidade somestésica inclui a percepção mecânica (tato, textura, pressão, vibração, estereognosia), dolorosa e térmica (frio e calor). A percepção mecânica está relacionada às fibras mais grossas, principalmente do tipo $A \beta$, e a percepção térmica e dolorosa relacionadas às fibras mais finas (tipo $A \delta$ e tipo $C$ ) (Gardner et al., 1989; Mountcastle, 1995). A percepção táctil envolve a despolarização do aferente primário que leva informações ao corno posterior da medula e núcleos trigeminais, onde fazem sinapse com neurônios de segunda ordem, que se projetam ao tálamo contralateral, de onde partem neurônios de terceira ordem, que se conectam ao córtex somatosensitivo primário (S-I) localizado no giro pós-central do lobo parietal (Sessle, 2000; Gardner e Kandel, 2003). O córtex somatosensitivo primário contém quatro áreas distintas (Brodmann 3a, 3b, 1 e 2). As áreas $3 b$ e 1 recebem informações da pele e as outras informações proprioceptivas de músculos e articulações. Entretanto, há inúmeras interconexões o que é importante na 
elaboração das informações. O córtex somatosensitivo secundário (S-II), localizado na parte superior da fissura lateral, refere aferências das quatro áreas de S-I. Já S-II projeta-se ao córtex insular, que inerva áreas do lobo temporal, importantes para a percepção táctil (Mountcastle, 1995). Áreas mais posteriores (córtex parietal posterior - áreas 5 e 7 de Brodmann) têm função associativa e se comunicam bilateralmente pelo corpo caloso. A área 5 integra informações tácteis exteroceptivas e proprioceptivas dos dois lados e a área 7 recebe informações visuais, tácteis e proprioceptivas integrando estereognosia com visão. Essas áreas projetam-se para áreas motoras no lobo frontal e orientam o movimento através de percepções sensitivas (Gardner e Kandel, 2003). A sensibilidade somestésica não é estável ao longo da vida e diminui com a idade, principalmente em mulheres depois da menopausa (Storey e Kenny, 1989; Ryhammer et al., 1997; Petersen et al., 2001)

Há sempre pelo menos três neurônios entre o receptor periférico e S-I (Teixeira, 2001). Os neurônios corticais que recebem a informação mecânica são de adaptação lenta ou rápida, e sinalizam a amplitude e a frequência da deformação cutânea periférica. Cada neurônio cortical representa um campo receptivo externo e, quanto mais externa a camada de neurônios corticais piramidais, maior o campo receptivo (Favorov e Kelly, 1994). Sendo assim, os campos receptivos dos neurônios corticais são muito maiores do que o campo receptivo de neurônios primários sensitivos. A sensibilidade periférica apresenta então uma grande convergência e é importante ressaltar que essas áreas não são fixas e podem se modificar de 
acordo com a experiência sensitiva ou por lesões (Mountcastle, 1997). Os campos receptivos parecem ser formados durante o desenvolvimento e mantidos de acordo com ativação simultânea de aferências. Embora os campos receptivos cubram grandes áreas da pele, uma informação pode ser bem discriminada porque a área central do campo receptivo é a que mais recebe a informação. Essa amplificação do campo receptivo, quanto mais cortical for o neurônio, se deve por conta da circuitaria dentro dos núcleos de retransmissão ou de projeção e de neurônios inibitórios relacionados a eles (Gardner et al., 1989). Dessa maneira, simultânea à convergência de informações está uma divergência ampla pela circuitaria de retransmissão. As conexões pós-sinápticas são convergentes, porém as pré-sinápticas são divergentes por conta desse padrão (Gardner e Kandel, 2003).

Além da distribuição por campo receptivo, a informação também é segregada por modalidade. O córtex é organizado em colunas de cerca de 300-600 $\mu \mathrm{m}$ de largura, cujo centro é a camada IV dentre as seis camadas e que recebe a informação de um campo receptor relativo a uma modalidade sensitiva (Mountcastle, 1997). Essa organização é consequência direta de projeções talâmicas perpendiculares ao córtex que terminam em neurônios estrelados da camada IV dentro de cada coluna. A camada IV projeta-se de volta ao tálamo; II e III projetam-se para outras áreas corticais e V para estruturas subcorticais (Gardner e Kandel, 2003). 


\subsubsection{Dor trigeminal}

A sensação álgica é percebida através de terminações nervosas livres, que podem ser de três classes distintas: térmicas, mecânicas e polimodais. Nociceptores térmicos são fibras de pequeno calibre e pouco mielinizadas (Aס) ativadas por temperaturas extremas $\left(>45^{\circ} \mathrm{C}\right.$ ou $\left.<5^{\circ} \mathrm{C}\right)$; nociceptores mecânicos são também fibras Aঠ̃ ativadas através de pressão intensa e nociceptores polimodais são aqueles do tipo C (pequeno calibre e amielinizados) capazes de traduzir sinais diversos (químicos, térmicos, mecânicos) como dor (Dubner e Ruda, 1992; McMahon e Koltzenburg, 1990). Geralmente, a percepção dolorosa inicia-se pelas fibras tipo $A \delta$, seguidas de ativação de fibras do tipo C. Alguns nociceptores são silenciosos e têm seus limiares reduzidos na inflamação; estes estão muito envolvidos em fenômenos como hiperalgesia secundária e sensibilização central (Teixeira, 1995; Basbaum e Jessell, 2003).

Os aferentes primários nociceptivos terminam no corno dorsal da medula espinal, e no caso do sistema trigeminal, principalmente no subnúcleo caudado do complexo trigeminal (Sessle, 2000). Existe uma distribuição da informação sensitiva dolorosa principalmente nas camadas I, II e V de Rexed. Na camada I, chegam muitas aferências nociceptivas tipo Aঠ் e C que fazem sinapse com neurônios nociceptivos específicos, e também com neurônios de amplo espectro dinâmico; estes recebem aferências tanto de nociceptores como de mecanoceptores. A camada II é basicamente composta de interneurônios excitatórios e inibitórios, as camadas III e IV recebem aferências não-nocivas e apresentam 
monossinapses de fibras $A \beta$ e a camada $V$ contém, principalmente, neurônios de amplo espectro dinâmico que são monossinápticos e recebem aferências de fibras $A \beta$ e $A \delta$, além de informações nociceptivas viscerais (Talbot et al., 1991; Sessle, 2000). A convergência de informações somáticas e viscerais nessa região é responsável pela "dor referida", em que uma víscera lesionada apresenta sintomas em estruturas da superfície corporal (Sessle, 2000; Teixeira et al., 2003). A camada VI recebe informações proprioceptivas de músculos e articulações, e as camadas VII e VIII apresentam neurônios polissinápticos, e assim, suas propriedades são muito mais complexas, além de receberem informações dos dois lados do corpo. Suas comunicações com a formação reticular podem contribuir com muitas formas de dor difusas (Basbaum e Jessell, 2003). As fibras trigeminais competem por um território alvo no tronco encefálico, e isso ocorre não só na infância, mas também, na vida adulta, especialmente em situações de lesão nervosa, através do aumento da arborização dos terminais (Renehan et al., 1994).

O principal neurotransmissor excitatório relacionado à condução dolorosa é o glutamato, que atua diretamente em receptores ácido a-amino3-hidroxi-5-metil-4-isoxazolepropiônico (AMPA) ligados a canais de sódio. Também há a liberação de neuropeptídeos pelos aferentes primários como a substância $P$, que resultam em estimulação lenta de fibras pós-sinápticas, e assim, prolongam os potenciais de ação gerados pelo glutamato (Baumann et al., 1991). Após uma lesão inicial, há modificações locais nos tecidos principalmente do tipo inflamatórias relacionadas aos eventos de 
sensibilização primária observados, ou seja, existe uma diminuição nos limiares de percepção dolorosa e ativação de fibras silenciosas resultando consequentemente em hiperalgesia primária. Os axônios estimulados por dor, por si só, passam a responder mais rapidamente a um novo estímulo álgico. Na inflamação, diversas substâncias sensibilizam os nociceptores, como bradicinina, histamina, prostaglandinas, leucotrienos, acetilcolina, serotonina (Anbar e Gratt, 1997); neuropeptídeos são liberados pelos terminais nervosos como a substância $\mathrm{P}$ e o peptídeo relacionado ao gene da calcitonina (CGRP) e prolongam a sensibilização que lá ocorre, além de induzirem liberação de peptídeos vasoativos (inflamação neurogênica) (Baumann et al., 1991). No caso de dano persistente, fibras C disparam repetidamente nos neurônios secundários aumentando progressivamente sua resposta, amplificando a sensação, por abertura de canais de cálcio relacionados ao receptor glutamatérgico N-Metil-D-aspartato (NMDA) (Teixeira, 1995; Teixeira et al., 2003). Este, está envolvido na potencialização de longo prazo e em fenômenos neuroplásticos, sensibilizando centralmente e gerando hiperalgesia secundária (Baumann et al., 1991). Assim, perifericamente, uma área mais ampla do que a área efetivamente alterada passa a ser percebida como dor.

A informação nociceptiva é conduzida ao sistema nervoso central através de cinco vias: trato espinotalâmico, espinorreticular, espinomesencefálico, cervicotalâmico e espino-hipotalâmico (Teixeira, 1995; Teixeira, 2001). O trato espinotalâmico é composto de fibras das camadas I, V-VII, é o mais proeminente e suas fibras se projetam ao lado contralateral; 
o trato espinorreticular mantém a maioria de suas fibras (das camadas VII e VIII) no mesmo lado de origem; o tratoespinomesencefálico se projeta através da formação reticular mesencefálica aos núcleos parabranquiais e amígdala e suas fibras são procedentes das camadas I e V; o trato cervicotalâmico se origina do núcleo cervical lateral e recebe aferências de camadas III e IV que cruzam a linha média; e o trato espino-hipotalâmico apresenta neurônios das camadas I, V e VIII para centros supra-espinais de controle neurovegetativo (Teixeira, 1990; Basbaum e Jessell, 2003).

Núcleos talâmicos processam a informação nociceptiva (principalmente medial e lateral), e a conduzem para centros corticais. Seu processamento está relacionado à localização e aspectos discriminativos da dor. Além disso, há projeções diretas a regiões do sistema límbico envolvidas nas emoções e no comportamento da dor (Teixeira, 2004; Wachholtz, 2007).

É importante salientar que, além dessas estruturas ascendentes, uma das mais importantes descobertas foram os circuitos modulatórios descendentes que regulam a percepção de dor. Na medula espinal ocorre o fenômeno de inibição da informação nociceptiva através da ativação de interneurônios ativados por fibras mais grossas, relacionadas à informação não-nociceptiva. Este mecanismo ficou conhecido como "Teoria da Comporta" descrita por Melzack e Wall, na década de 60 (Melzack e Wall, 1965). Também é possível haver inibição da informação dolorosa através da estimulação de regiões como a substância cinzenta periaquedutal ou áreas 
do córtex motor; vias serotoninérgicas, noradrenérgicas e opioides descendentes estão envolvidas neste processo (Basbaum e Jessell, 2003).

\subsection{Olfação e gustação}

Os sentidos químicos, representados pelo olfato e gustação, são altamente integrados e compõem a sensação de paladar, juntamente com outras informações trigeminais somestésicas da mucosa oral (Bartoshuk, 1988). Neurônios químicos diferentes são específicos para substâncias químicas diferentes, mas cada neurônio pode reconhecer uma variedade delas. Isso pode ocorrer devido a múltiplas cascatas de sinalização no mesmo neurônio correspondentes com a percepção de cada estímulo (Bartoshuk e Beauchamp, 1994; Buck, 2003).

A percepção sensitiva olfatória depende do reconhecimento da estrutura molecular do agente odorífero, variando de acordo com a sua concentração, e ocorre através de cerca de seis milhões de neurônios sensitivos bipolares especializados, localizados na porção posterior da cavidade nasal em uma área com cerca de $5 \mathrm{~cm}^{2}$, capazes de perceber mais de 300 tipos de estímulos diferentes (Doty, 2009), através de mais de 1000 receptores distintos (Axel, 1995); tratam-se de células epiteliais ciliadas cercadas por células do tipo glia, localizadas acima da camada basal de células germinativas. Esses neurônios são distintos dos outros porque têm vida curta (cerca de 30 a 60 dias) e são repostos continuamente por essas células germinativas basais (Axel, 1990). Os cílios destas células têm 
receptores específicos para agentes odoríferos, e realizam a transdução e amplificação de potenciais de ação no axônio neuronal. As células de suporte e as glândulas de Bowman secretam muco, cuja propriedade é fornecer o ambiente molecular e iônico apropriado para a detecção de odores. Algumas de suas proteínas contribuem ligando-se aos agentes odoríferos e facilitando sua concentração para detecção ou sua remoção (Buck, 2003).

A transdução de sinais ocorre através de sete regiões hidrofóbicas transmembranares que sinalizam por meio de guanosina trifosfato (GTP); há a indução de aumento da atividade de adenilato ciclase e adenosina monofosfato cíclico (AMPc) o que promove a abertura de canais iônicos catiônicos gerando despolarização de membrana e potenciais de ação (Sullivan et al., 1005). Quando permanecem ativos perante uma mesma concentração, há a breve adaptação desses receptores, o que se deve à inativação ou dessensibilização por fosforilação por uma proteína quinase ou, ainda, por um ajuste de sensibilidade dos canais iônicos ativados por $\mathrm{AMPc}$, condição análoga à adaptação visual à quantidade de luz do ambiente (Buck, 2003).

Cada gene de receptor odorífero é expresso em apenas $0,1 \%$ dos neurônios olfatórios, o que sugere que cada neurônio expressa somente um tipo de receptor. Os neurônios que expressam alguns tipos de receptor se localizam em quatro grandes zonas distintas, porém cada receptor é distribuído de maneira dispersa, o que faz com que mesmo que haja perdas de áreas epiteliais a percepção da informação é mantida, desde que a perda 
não seja muito extensa (Axel, 1995). A informação é organizada e enviada ao encéfalo através destas quatro zonas. Cada neurônio olfatório envia sua informação para um glomérulo (unidade sináptica do bulbo olfatório) (Vassar et al., 1994; Sullivan et al., 1995). O axônio sensitivo olfatório faz conexões com três tipos de neurônios em cada glomérulo: neurônios de retransmissão mitral e em tufo (projetam axônios ao córtex olfatório), e interneurônios poliglomerulares (circundam o glomérulo). Milhares de neurônios olfatórios convergem para um glomérulo em cerca de 20-50 neurônios de retransmissão ou tufo (Vassar et al., 1994). Aparentemente, os glomérulos funcionam como unidades funcionais e cada um deles recebe informação de somente um receptor. Quando um agente odorífero estimula muitos glomérulos, significa que ele é percebido por vários tipos de receptores. A informação é altamente processada no bulbo antes de prosseguir ao córtex olfatório; existem interneurônios inibitórios e há, também, aferências para o bulbo provenientes do córtex que modulam sua função, por exemplo intensificando os cheiros no momento em que há fome (Doty, 2009).

A informação proveniente do bulbo olfatório é transmitida ao córtex através do trato olfatório lateral. Há cinco áreas do córtex que recebem a informação (córtex piriforme, parte da amígdala, tubérculo olfatório e parte do córtex entorrinal) (Vassar et al., 1994). As últimas quatro áreas retransmitem a informação ao córtex através do tálamo. Há também conexões diretas do córtex olfatório com o córtex frontal. Acredita-se que as vias aferentes que passam pelo tálamo em direção ao córtex orbitofrontal sejam responsáveis pela percepção e discriminação de odores; as vias 
relacionadas à amígdala e hipotálamo parecem relacionadas aos aspectos emocionais e motivacionais (Sullivan et al., 1005; Buck, 2003).

A anormalidade olfativa mais comum é a anosmia específica a um odor, devido à falta de um determinado receptor, e que é comum na população geral (Buck, 2003). Muitas doenças afetam a sensibilidade olfativa, como neoplasias, infecções virais, doenças renais, epilepsia e doenças neurodegenerativas. As mulheres têm limiares menores do que os homens. Com a idade, a sensibilidade olfativa diminui (Doty, 2009). É importante observar que a perda de sensibilidade olfativa pode preceder a instalação de doenças neurodegenerativas com Doença de Parkinson e Doença de Alzheimer (Doty, 2009).

A sensibilidade gustativa ocorre através de células agrupadas em botões gustativos capazes de detectar quatro tipos básicos de estímulos (amargo, doce, salgado e azedo) (Bartoshuk e Beauchamp, 1994). Uma quinta categoria discutível é o glutamato monossódico (umami) (Bartoshuk, 1988). Existem três tipos distintos de papilas (fungiformes, nos dois terços anteriores; circunvaladas no terço posterior; e foliadas, na borda posterior da língua). Cada papila fungiforme contém de um a cinco botões gustativos, enquanto que cada papila circunvalada ou foliada contém centenas de botões gustativos. Cada botão gustativo contém quatro tipos de células: basais, escuras, claras e intermediárias. Acredita-se que as basais sejam as germinativas, que constantemente repõem as células gustativas de vida muito curta (Buck, 2003). Todas as outras três são gustativas, de forma alongada e estendem-se da abertura epitelial do botão até sua base; 
representam estágios de diferenciação da mesma célula basal, sendo as claras as mais diferenciadas. A abertura epitelial é chamada de poro gustativo (Bartoshuk, 1988; Bartoshuk e Beauchamp, 1994). As cem ou mais células gustativas em cada botão estendem microvilosidades no poro, onde se expõem à cavidade oral e realizam a transdução sensitiva. Essas células são inervadas por neurônios primários sensitivos no seu polo basal, onde fazem uma espécie de sinapse química. As células gustativas são excitáveis através de substâncias iônicas e são capazes de gerar potenciais de ação (Buck, 2003; Bartoshuk et al., 2005).

Em geral, os agentes químicos agem em receptores específicos da membrana apical das células gustativas gerando, segundo mensageiros ou diretamente através de canais iônicos despolarizando a membrana. Secundariamente, há um influxo de cálcio por canais dependentes de voltagem e a liberação de neurotransmissores na sinapse com o aferente primário. O cálcio também pode ser proveniente de estoques intracelulares. Os sabores salgado e azedo estão relacionados com atividade direta iônica na membrana da célula gustativa (íons de sódio e de hidrogênio respectivamente) e os sabores doce e amargo dependem de sinalização através de proteína G e de GTP, após ativação de receptor na membrana, causando aumento de AMPc ou de inositol trifosfato $\left(\mathrm{IP}_{3}\right)$ citoplasmáticos (Akabas, 1990; Buck, 2003). É interessante observar que apesar do sódio ser o mais importante elemento na percepção do gosto salgado, foi evidenciado que o cloro apresenta papel complementar nesta percepção e, em outros sais onde o sódio não faz parte, ele determina o gosto salgado 
(Ye et al., 1994). O sistema gustativo de transdução do sódio envolve dois mecanismos, transcelular e paracelular, e ambos são necessários para a percepção normal, não dependendo do tamanho do ânion (Roitman e Bernstein, 1999; Geran e Spector, 2000; St John e Smith, 2000). Para o sabor doce, parece haver dois mecanismos distintos: o fechamento de canais de potássio basolaterais dependentes de AMPc, o que gera uma despolarização porque, geralmente, eles ficam abertos na condição de repouso ou a liberação de cálcio de estoques intracelulares por aumento citoplásmatico de $\mathrm{IP}_{3}$, mecanismo mais comumente relacionado aos adoçantes artificiais (Bartoshuk e Beauchamp, 1994). O sabor amargo está relacionado frequentemente com venenos e substâncias tóxicas, e sua percepção está relacionada à proteção. Essas substâncias incluem cátions divalentes, alguns aminoácidos, alcalóides e denatônio, a substância mais amarga que existe. Algumas são permeáveis à membrana (ex. quinino) e bloqueiam diretamente canais de potássio, e outras (ex: denatônio) estão relacionadas a receptores acoplados a proteína G, que geram aumento intracelular de AMPc e $\mathrm{IP}_{3}$ da mesma maneira que as substâncias doces (Buck, 2003).

Células gustativas distintas podem responder a estímulos diferentes e agir em isolado ou combinadas. Sua atividade elétrica é percebida por ramificações de um único aferente primário, que leva a informação através dos gânglios geniculado (nervo corda do tímpano, VII par craniano), petroso (IX par craniano) e / ou nodoso (X par craniano) até o núcleo do trato solitário no bulbo (tronco encefálico), mais especificamente 
em sua área gustativa (parte rostral e lateral desse núcleo) (Bradley e Grabauskas, 1998). No núcleo do trato solitário, as células que analisam o sabor são agrupadas separadamente de outras modalidades somestésicas da língua. Através da região parvocelular do núcleo ventroposteromedial do tálamo, a informação segue a uma porção do córtex que é rostral ao córtex somatosensitivo da língua, onde ocorre a consciência e discriminação de estímulos gustativos. É importante lembrar que cada sabor apresenta-se distribuído em várias regiões linguais, e que a segregação espacial do sabor ocorre somente no núcleo, tálamo e córtex. Na percepção gustativa, a saliva tem um papel de destaque concentrando ou diluindo as substâncias, na mesma forma que o muco nasal (Buck, 2003). O núcleo do trato solitário apresenta projeções para o complexo parabraquial e para a formação reticular do tronco encefálico, e fatores como o apetite, o açúcar sanguíneo e níveis de insulina podem contribuir para a aversão a um tipo de sabor (Reilly, 1998; Small, 2006). Dentre os neurotransmissores envolvidos na facilitação e na inibição, estão a substância $P$ e o ácido gama-aminobutírico (GABA) (Smith et al., 1998). Aparentemente, há uma via gustativa secundária rostral ao trato solitário sem cruzar a linha média (Shikama et al., 1996). A sensibilidade gustativa pode ser investigada de diversas formas, entre elas através de testes elétricos (Tomita et al., 1986).

Foi descoberto que uma única fibra gustativa, apesar de específica a um estímulo, também responde a outros sabores em graus variados. Fibras relacionadas ao sal podem, também, responder ao ácido, e fibras de ácido podem, também, responder ao amargo. Isso sugere que a 
percepção do sabor depende da atividade da população inteira de fibras ou da ativação de grupos diferentes de fibras, porém sobrepostos. E para a percepção é necessária a exclusão de outros sabores (Buck, 2003). Isso justifica porque nas avaliações de sabor é necessária a distribuição do produto em toda a língua para sua detecção. Não se sabe se as quatro zonas olfatórias apresentam alguma relação com os quatro sabores básicos gustativos. Estudos em epilépticos com aura gustativa mostraram que as áreas gustativas corticais primária e secundária são, respectivamente, a insula e o lobo temporal anteromedial (Sanchez-Juan e Combarros, 2001).

Pacientes com infecções virais do nervo facial frequentemente apresentam anormalidades gustativas devido à lesão direta do nervo corda do tímpano. Também na PF, anormalidades gustativas são comuns (Kohjitani et al., 2002).

\subsection{Integração da informação sensitiva orofacial}

Os receptores sensitivos estão conectados a uma maquinaria altamente flexível, capaz de discriminar uma variedade de informações do ambiente que se apresentam em fluxo contínuo. Essas informações geram comportamentos precisos determinados por circuitos anatômicos reforçados de acordo com a exposição ao estímulo, armazenados na forma de memória (Kandel, 2003). Para a percepção coerente, a integração sensitiva é essencial, e depende do tamanho do campo receptivo dos neurônios envolvidos, da correta inibição de estímulos desnecessários, e da 
convergência de informações em áreas corticais de associação (Favorov e Kelly, 1994; Gardner e Kandel, 2003). São detectadas regularidades diante da aparente confusão de informações sensitivas, confrontadas com dados guardados na memória (Gardner et al., 1989). As áreas de associação apresentam uma organização mais funcional do que topográfica (Gardner e Kandel, 2003).

No caso da percepção oral, é essencial compreender-se que esta depende de uma integração somestésica, gustativa e olfativa (Sherrington, 1947). Boa parte da percepção gustativa é olfatória e ocorre durante o movimento de mastigação através da liberação de substâncias voláteis pela porção retronasal e comunicação faringeana (Bartoshuk, 1988; CerfDucastel e Murphy, 2001). Acredita-se que a participação somatosensitiva seja a responsável por localizar a sensação olfativa do paladar como na língua (Savage, 1970). A sensação gustativa em si tem um componente somatosensitivo que inclui a textura do alimento, sensações picantes (fibras de dor e calor), mentoladas (fibras de frio) e grau de carbonatação (além da acidez, que pode causar estímulos em fibras finas de dor) (Bartoshuk e Beauchamp, 1994). Neste contexto, a saliva tem um papel devido a suas características protetoras do epitélio bucal e gastrointestinal, e como mediadora da transdução (Coelho et al., 2002). Sua ausência, caracterizada pela sensação subjetiva de boca seca (xerostomia), pode comprometer a sensibilidade oral (Thomson, 2005). Sua propriedade lubrificante auxilia na formação e deglutição do bolo alimentar, facilita a fonação, é essencial na retenção de próteses totais e previne contra danos nos tecidos por agentes 
mecânicos ou por estímulos nocivos provocados por microorganismos (Buzalaf et al., 2006). Os componentes salivares também interferem facilitando ou dificultando a percepção gustativa, e incluem uma grande variedade de eletrólitos, peptídeos, glicoproteínas (Song et al., 2000), lipídeos, lisozima, lactoferrina, sistemas de peroxidase, imunoglobulina A (Rivera et al., 2001), histamina, mucina, fator de crescimento epidermal (Eckley e Costa, 2003) e leucócitos fagocitários (Coelho et al., 2002).

Diversos estudos em animais têm elucidado os mecanismos de funcionamento e interação sensitiva entre os sistemas somestésico, gustativo e olfativo. Neurotomia do nervo corda do tímpano gera aumento no limiar salgado em roedores (Kopka et al., 2000) e neurotomia do glossofaríngeo aumenta o limiar amargo (Travers et al., 1987; Grill et al., 1991; King et al., 1999; King et al., 2000). Quando a interrupção desses nervos é simultânea, mesmo na regeneração de um deles não há normalização das sensações, o que demonstra que um depende do outro para a percepção (Spector et al., 2005). Recentemente, demonstrou-se que o subnúcleo oralis do complexo trigeminal também media informações gustativas (Dallel et al., 2004). Em casos de lesão nervosa do ramo corda do tímpano, do trigêmeo ou do glossofaríngeo, quanto mais próxima da periferia, maior é a perda sensitiva gustativa (Hendricks et al., 2002). A sensação gustativa percebida é uma mistura de efeitos excitatórios e inibitórios que ocorrem no tronco encefálico e no tálamo, sendo que os excitatórios provém dos aferentes que liberam glutamato, e os inibitórios estão relacionados à interneurônios via sinapses GABA-A (Bradley et al., 
1996). Há uma convergência complexa de estímulos que provém do nervo corda do tímpano e do glossofaríngeo no tronco encefálico, o que mostra que boa parte do processamento das informações ocorre nesse primeiro nível (Grabauskas e Bradley, 1996). Em sapos, dependendo do estímulo gustativo químico utilizado na língua, ocorre aumento ou diminuição da atividade antidrômica; já a alteração do potencial de membrana através de corrente elétrica não é capaz de gerar estas anormalidades. Esses achados reforçam mecanismos periféricos de interação entre gustação e somestesia na língua de sapos (Kutynal e Bernard, 1977).

O núcleo rostral do trato solitário é o primeiro centro de informações gustativas e tem uma função muito importante na modulação e processamento da gustação, seguido do núcleo parabraquial. Evidências mostram que receptores delta-opioides estão envolvidos neste processo (Zhu et al., 2009). A circuitaria de percepção sensitiva gustativa da língua envolve conhecidas áreas gustativas (subdivisão rostral central do núcleo do trato solitário, sinapses principais de axônios geniculados, projeções para o núcleo parabraquial da ponte) mas, também, a subdivisão rostral lateral do núcleo do trato solitário, que recebe informações trigeminais e geniculadas (Krout e Loewy, 2000), e a área ventral do núcleo do trato solitário e formação reticular medular, responsáveis pela interação com reflexos oromotores. Esses reflexos estão relacionados ao sistema trigeminal para a mastigação e deglutição (Monroe e DiLorenzo, 1995; Travers e Hu, 2000; Zaidi et al., 2008). As evidências apontam também para uma modulação de origem visceral e, também, de experiência anterior na percepção gustativa, 
que envolve vias descendentes provenientes do córtex anterior. A estimulação elétrica do núcleo central da amígdala modula a intensidade e tipo de informação gustativa que é transmitida pelo núcleo parabraquial (Lundy e Norgren, 2001). Após estimulação gustativa através de substância doce na língua, ocorre ativação de células do epitélio nasal quimioreceptoras e também de vias trigeminais (Ohmoto et al., 2008). É evidente que neurônios do trato solitário não só se projetam para mas recebem estímulos descendentes dos núcleos parabranquiais bilateralmente e que ambos os núcleos se comunicam com o lado contralateral (Cho e Li, 2008).

No caminho ascendente da informação gustativa entre o núcleo parabraquial e o córtex gustativo via tálamo, a parte parvicelular do núcleo ventroposteromedial talâmico é a peça chave. Células do núcleo parabraquial se projetam para este núcleo talâmico bilateralmente, e dele retornam potenciais inibitórios que modulam as sensações gustativas (Mao et al., 2008). A distribuição axonal de fibras descendentes provenientes do hipocampo, relacionadas à memória, em direção ao tálamo e hipotálamo, também se projetam para os córtexes visual, auditivo, somatosensitivo, olfativo, gustativo, além de áreas límbicas, e podem estar relacionadas a efeitos funcionais sensitivos e anormalidades clínicamente observadas decorrentes de potenciação de longo tempo de estímulos sensitivos diversos (Cenquizca e Swanson, 2007). As evidências apontam também para uma modulação de origem visceral e também de experiência anterior na percepção gustativa, que envolve vias descendentes provenientes do córtex anterior. A estimulação elétrica do núcleo central da amígdala modula a 
intensidade e tipo de informação gustativa que é transmitida pelo núcleo parabraquial (Lundy e Norgren, 2001).

Durante a alimentação, nos tecidos periféricos orais aparentemente cada neurônio é específico a um estímulo, porém, no sistema nervoso central grupos de neurônios de sensações análogas determinam a magnitude do mesmo, o que se torna complexo dada a convergência de qualidades diferentes de informação a áreas centrais. Foi observado em estudos animais que quaisquer misturas de sabores geram uma resposta ambígua (Ganchrow e Erickson, 2000), e que amostras misturadas geralmente geram resposta aproximada ao sabor mais presente na mistura. Alguns neurônios inclusive respondem melhor a uma mistura do que a um único sabor. Eles recebem convergências de neurônios que percebem só um sabor e tem um poder de amplificação do sabor mais frequentemente sentido naquela mistura (Chen e DiLorenzo, 2008). Sabe-se que doce e amargo utilizam circuitarias segregadas no sistema nervoso central, mas apresentam modulação periférica. Mesmo essa circuitaria segregada leva a áreas corticais que, apesar de distintas para cada tipo de sabor, apresentam-se totalmente sobrepostas para salgado, azedo, amargo e doce (Accolla et al., 2007).

O padrão de ativação cortical depende da característica emocional do sabor (agradável ou desagradável), mesmo em composições de sabores, para ativar áreas corticais (Accolla et al., 2007). O modelo mais comumente utilizado de pesquisa dessas interações de supressão de sabor é a inibição do sabor doce pela presença do amargo. Isso acontece porque o 
canal catiônico TRPM5 envolvido na transdução do doce é inibido por componente amargo como quinina, pois acelera o fechamento deste canal (Tavalera et al., 2008). Esta modulação é totalmente periférica. As papilas gustativas são distribuídas de maneira não uniforme de acordo com o nervo (corda do tímpano, vago ou glossofaríngeo), o que pode também contribuir para variações na percepção gustativa determinando provavelmente a qualidade nutricional do alimento (Eram e Michel, 2006). A analgesia observada pelos açúcares presentes no aleitamento materno pode dever-se à inativação de vias centrais que mediam a dor, como substância cinzenta periaquidutal e nucleo magno da rafe, além da estimulação própria das vias gustativas (Anseloni et al., 2005).

A simples lesão de fibras trigeminais em animais altera a palatabilidade e reforça a necessidade de integridade trigeminal para a sensibilidade gustativa (Berridge e Fentress, 1985). A percepção do sabor depende de uma integração neural de estímulos olfativos, gustativos e trigeminais, porém ainda não se sabe em qual localização cerebral essas sensibilidades efetivamente se integram (Shipley e Geinisman, 1984). Existem inclusive evidências da interação química (gustação e olfato) com a visual (Alkon et al., 1978). A modulação gustativa depende também da variação térmica, ou seja, quanto mais quente melhor a percepção (Bajec e Pickering, 2008).

Também o sistema trigeminal está intimamente conectado com o sistema olfativo (Frasnelli e Hummel, 2007; Frasnelli et al., 2007), e mecanismos adaptativos periféricos parecem reduzir a responsividade 
trigeminal em situações de hiposmia ou anosmia (Frasnelli et al., 2007). Essa interação ocorre de maneira direta, ou seja, muitos odorantes não só estimulam o nervo olfativo, mas também diretamente receptores trigeminais. A sensibilidade anterior da mucosa nasal parece ser mais acurada e a sensibilidade da porção mais posterior ser mais sensível a estimulação mecânica. Isto pode estar relacionado com a sensibilidade retronasal olfativa do paladar, na alimentação (Frasnelli et al., 2004).

\subsection{Metodologia de avaliação sensitiva em dor orofacial}

Nas últimas décadas, foram desenvolvidas metodologias de TSQ com o intuito de avaliar a sensibilidade de forma quantitativa em humanos, o que têm contribuído para a elucidação dos mecanismos envolvidos no processamento sensitivo orofacial (Eliav et al., 2004; Pigg et al., 2009). Doentes com DFIP não apresentaram diferenças marcantes quando comparados a controles (Lang et al., 2005; Forssell et al., 2007); já doentes com história prévia de trauma facial apresentaram processamento anormal da informação sensitiva trigeminal (List et al., 2008; Sardella et al., 2009). É importante lembrar que medicamentos utilizados no tratamento da dor podem, também, contribuir para as anormalidades observadas.

Nos exames, é frequente encontrar a sensibilidade somestésica alterada gerando queixa subjetiva gustativa (Heckmann e Lang, 2007). Foi observado que pacientes com disestesia oral com ou sem disgeusia apresentaram limiares de percepção de sabor semelhantes; à 
carbamazepina afetou subjetivamente a percepção de gosto, mas não houve diferença de limiar. As queixas de gustação observadas em pacientes com disestesia se devem mais a anormalidades somatosensitivas do que gustativas propriamente ditas (Etoh et al., 2008). A estimulação unilateral com cloreto de sódio na língua, em indivíduos que apresentavam o nervo corda do tímpano contralateral lesionado, gerou ativação bilateral (Onoda et al., 2005). A perda da sensibilidade gustativa em pacientes após cirurgia trigeminal apoia a existência de uma via gustativa acessória pela raiz trigeminal e gânglio trigeminal (Sanchez-Juan e Combarros, 2001). Também, há evidências dessa interrelação no sistema nervoso periférico; suportada por estudos em animais que mostram interações importantes gustativas e olfativas na formação do gânglio trigeminal (Shiau et al., 2008). Nos casos de lesão nervosa lingual, envolvendo ramos do nervo corda do tímpano e do lingual trigeminal, é comum observar rápida regeneração de fibras mais grossas relacionadas a mecanoceptores e tardia recuperação de fibras finas, inclusive aquelas relacionadas à sensibilidade gustativa (Holland, 1996).

A linha de pesquisa em dor trigeminal realizada pela Equipe de Dor Orofacial da Divisão de Odontologia do Hospital das Clínicas da Faculdade de Medicina da Universidade de São Paulo (FMUSP) e pelo Centro Interdisciplinar de Dor do Departamento de Neurologia da FMUSP, também apresenta resultados consistentes com esses achados internacionais. Em 1984, Teixeira observou queixas gustativas em doentes com NIT que haviam sido submetidos a cirurgias percutâneas como tratamento (Teixeira et al., 2006), o que levou ao estudo quantitativo 
sensitivo dessas anormalidades realizado por Siqueira em 2006. Neste estudo, observou-se que as queixas eram transitórias e que envolviam anormalidades somatosensitivas, gustativas e olfativas (Siqueira et al., 2006a; Siqueira et al., 2006c).

Outros doentes com dor orofacial (NPH e SAB) também foram estudados posteriormente. Anormalidades sensitivas somestésicas foram encontradas além do ramo afetado na NPH trigeminal (Alvarez et al., 2007) e limiares olfativos aumentados foram frequentes nesses doentes e na SAB, quando comparados a controles (Siviero et al., 2010; Siviero et al., 2011a; Siviero et al., 2011b). Limiares gustativos salgados e doces foram encontrados aumentados nesses doentes, porém, os limiares ao azedo foram encontrados reduzidos (Siviero et al., 2010). Não se sabe exatamente as razões para isso, mas acredita-se que a mediação de radicais de hidrogênio, tanto no sabor azedo como na dor, pode ser a causa em potencial. No caso da SAB, outros autores já haviam observado anormalidades gustativas, além de alterações quantitativas e qualitativas salivares (Grushka e Sessle, 1998; Formaker e Frank, 2000; Forssell et al, 2002; Femiano et al., 2008, Eliav et al., 2007), porém em nosso grupo foi a primeira vez que a percepção olfativa foi avaliada. Anormalidades sensitivas trigeminais podem indicar alterações como glicemia aumentada em doentes com Diabetes mellitus (Arap et al., 2010). Além dessas queixas, foram identificadas anormalidades subjetivas visuais e auditivas nos doentes com NIT tratados com microcompressão do gânglio trigeminal (Siqueira et al., 2006d). 
Com a idade, ocorre um aumento nos limiares somestésicos, gustativos e olfativos (Heckmann e Lang, 2007), possivelmente relacionado ao comprometimento das respostas imunes locais e regulação da neurogênese. Esta se dá em parte pelo ácido retinóico, que é menos consumido pelos idosos (Rawson e LaMantia, 2007). Outros fatores envolvidos são o consumo de medicamentos, doenças, variação da densidade e distribuição de receptores específicos e canais iônicos, e ainda a composição do muco nasal e saliva (Rawson, 2006).

Portanto, dadas as evidências, o sistema trigeminal parece mediar as sensações gustativas e olfativas em centros associativos cerebrais, e assim, determinar a localização e outras características relacionadas ao estímulo tendo, com isso, um papel crucial que pode ser fragilizado perante lesões ou anormalidades como dor crônica orofacial (Siviero et al., 2010). 


\section{CASUÍSTICA E MÉTOdOS}

\subsection{Sujeitos da pesquisa}

Para este estudo foram avaliados os bancos de dados relativos a todas as avaliações de sensibilidade de doentes com dor orofacial realizadas no período de Março de 2003 a Dezembro de 2009, compondo um número total de amostra de 459 indivíduos, sendo 364 doentes e 95 controles; estes corresponderam a todos os indivíduos em acompanhamento na Equipe de Dor Orofacial da Divisão de Odontologia e do Ambulatório de Algias Craniofaciais da Divisão de Neurologia do Hospital das Clínicas da FMUSP que foram encaminhados para a avaliação, e a 95 indivíduos controles recrutados entre funcionários das Divisões, voluntários externos e idosos frequentadores do Grupo de Assistência Multidisciplinar ao Idoso Ambulatorial (GAMIA) do Serviço de Geriatria da Clínica Médica do Hospital das Clínicas da FMUSP. Todos os sujeitos da pesquisa foram informados a respeito dos propósitos e assinaram o termo de consentimento. Este estudo foi aprovado pela Comissão de Ética em Pesquisa do Hospital das Clínicas da FMUSP (CAPPesq) sob o número 0751/10 (ANEXO 1). Foram utilizados dados compilados de projetos anteriormente realizados, de forma retrospectiva.

Critérios de inclusão: Doentes: Todos os doentes apresentavam dor por um período maior do que seis meses anterior à avaliação. NIT, NPH, 
NPT, SAB, e CC foram diagnosticados segundo os critérios da IASP (Merskey e Bogduk, 1994); NIT é caracterizada como dor repentina, geralmente unilateral, paroxística e recorrente na distribuição de um ou mais ramos do nervo trigêmeo, frequentemente associada a uma zona de gatilho, e que foi diferenciada da neuralgia trigeminal sintomática através de exames de imagem (ressonância magnética e/ou tomografia computadorizada); NPH trigeminal é descrita como dor crônica em um ou mais territórios do nervo trigêmeo e que persiste após três meses da infecção pelo vírus do Herpes zoster; NPT é caracterizada por dor crônica em queimação ou latejante podendo ser acompanhada por paroxismos na distribuição de um nervo periférico trigeminal, após uma lesão que ocorreu no período de três meses anteriores ao início da dor; SAB é descrita como dor oral em queimação sem sinais clínicos ou evidência de etiologia primária; CC é caracterizada por dor crônica moderada a grave unilateral em região frontotemporal geralmente irradiada de áreas cervicais ou occipitais que pode ser precipitada por movimentos do pescoço. Diabetes mellitus e ND foram diagnosticados por um endocrinologista treinado do Centro Interdisciplinar de Dor do Hospital das Clínicas da FMUSP, segundo os critérios da Organização Mundial de Saúde (OMS) (1999) e recomendações de San Antonio (1988) e fibromialgia foi diagnosticada por um fisiatra treinado da Divisão de Medicina Física do Instituto de Ortopedia e Traumatologia do Hospital das Clínicas da FMUSP, de acordo com os critérios da Academia Americana de Reumatologia (Wolfe et al., 1990), ou seja, dor crônica generalizada com duração maior de seis meses e 11 de 18 possíveis pontos de gatilho (dor generalizada é definida como dor nos segmentos superior, inferior e direito e esquerdo). DTM foi 
diagnosticada segundo os critérios da Academia Americana de Dor Orofacial (Okeson, 1996), ou seja, dor músculo-esquelética do aparelho mastigatório geralmente de leve a moderada, associada às funções mandibulares. SW e PF foram diagnosticadas por um neurologista que realizou o encaminhamento para a avaliação e, por fim, DFIP foi diagnosticada segundo os critérios da Associação Internacional de Cefaléias (International Headache Society Classification, 2004), ou seja, dor facial persistente que não apresenta as características das neuralgias clássicas e não é atribuída a outra causa. A dor é profunda e pobremente localizada, tipicamente descrita como contínua e de intensidade flutuante, sem história de trauma dentário

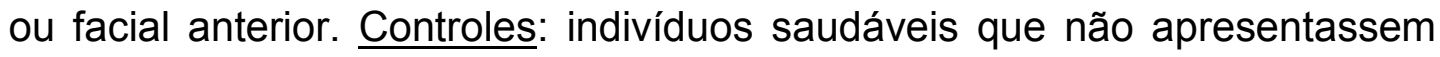
nenhum dos diagnósticos descritos e sem queixas de dor orofacial ou generalizada.

Critérios de exclusão: Doentes e controles: Histórico de trauma ou cirurgia na face ou crânio (exceto para os doentes com NPT), dor generalizada (exceto para os doentes com fibromialgia), doenças sistêmicas que causem neuropatias, doenças neurodegenerativas, neuroendócrinas (Diabetes mellitus - exceto no grupo de neuropatia diabética), reumáticas (lúpus eritematoso sistêmico, artrite reumatoide), neuroinfecciosas (hanseníase). Nenhum sujeito avaliado foi excluído por algum dos critérios acima.

Os doentes que apresentavam SAB, NPT, CC, DTM e DFIP não estavam em uso de nenhuma medicação nos últimos seis meses anteriores ao período de avaliação neste estudo. Os doentes que apresentavam ND 
estavam todos em uso de hipoglicemiantes apenas, os doentes com NIT utilizavam carbamazepina (doses de 400 a 1200 mg diárias), os doentes com NPH e fibromialgia estavam em uso de amitriptilina (25 a 150 mg diárias). Não houve variação de doses nos seis meses anteriores que antecederam a avaliação e os doentes receberam orientação de manter as doses durante o período dos exames. Nenhum controle estava em uso de medicação analgésica em um período de seis meses anterior ao da avaliação.

As características demográficas dos sujeitos avaliados foram comparadas utilizando-se o teste Qui-quadrado de Pearson (SPSS 17.0; SPSS Inc., Illinois, EUA).

\subsection{Métodos de avaliação}

A amostra total de 459 indivíduos foi avaliada através de duas metodologias distintas, de acordo com os equipamentos disponíveis e protocolo desenvolvido para a avaliação de sensibilidade, em cada período abaixo. Em Abril de 2009, o protocolo foi atualizado e novos equipamentos foram adquiridos, sendo estes validados internacionalmente para uso na região orofacial (Pigg et al., 2009). Os sujeitos foram então divididos em Amostras 1 e 2 .

1. Amostra 1. Entre Março de 2003 e Marco de 2009, os 336 sujeitos recrutados foram avaliados através do seguinte protocolo de TSQ: 
Avaliação subjetiva facial de sensibilidade: Todos os doentes e controles foram entrevistados quanto à percepção de anormalidades sensitivas faciais, que incluíam dormência e disestesia. A frequência das anormalidades sensitivas (ausente, eventual, frequente ou constante) e a intensidade da sensação (através da Escala Visual Analógica - EVA - que consiste de uma linha que vai de 0 a $10 \mathrm{~cm}$ sendo que 0 corresponde a 'nenhuma dor' e 10 corresponde a 'pior dor imaginável') foram coletadas.

\section{$\underline{\text { Testes sensitivos quantitativos (TSQ) }}$}

Todos os sujeitos foram submetidos a um protocolo padronizado de TSQ que consistiu em seis testes, desenvolvido pela Divisão de Neurocirurgia Funcional do Hospital das Clínicas e Departamento de Neurologia da FMUSP, agrupados conforme se segue:

- percepção térmica: frio e calor

- percepção mecânica: táctil e mecânica dolorosa

- percepção dolorosa: limiares de dor de superfície

- reflexo córneo-palpebral

As áreas faciais avaliadas incluíram os três ramos trigeminais (2 $\mathrm{cm}$ acima do centro da pupila, $2 \mathrm{~cm}$ abaixo do centro da pupila e $1 \mathrm{~cm}$ abaixo da comissura labial) bilateralmente. A percepção mecânica dolorosa foi também realizada nas regiões intraorais maxilar e mandibular (gengiva vestibular de pré-molares) (Siqueira et al., 2006a; Siqueira et al., 2006b; Alvarez et al., 2007; Siviero et al., 2010) . 
Todos os sujeitos foram avaliados na posição sentada, com a cabeça repousando em uma superfície lisa, em uma sala silenciosa com proteção acústica nas paredes e a porta fechada. Apenas o sujeito e o pesquisador encontravam-se na sala. Os doentes e controles foram orientados a permanecer com os olhos fechados durante todo o exame e estarem concentrados, e deveriam informar quando percebessem o estímulo e qual havia sido o estímulo aplicado. Apenas o pesquisador sabia a ordem dos estímulos. Os sujeitos foram avaliados por quatro pesquisadores distintos que haviam sido devidamente calibrados no período anterior ao do estudo.

(1) Percepção térmica. Testes térmicos foram realizados através do equipamento Thermosensi II (Divisão de Neurocirurgia Funcional do Instituto de Psiquiatria do Hospital das Clínicas e Departamento de Neurologia da FMUSP, Brasil). A temperatura de base era $32^{\circ} \mathrm{C}$ e a área de contato do termodo era de $10 \times 10 \mathrm{~mm}$. Estímulos de frio e calor foram aplicados em uma amplitude de 0 a $45^{\circ} \mathrm{C}$; o equipamento apresenta capacidade de mudança de temperatura de $1^{\circ} \mathrm{C} / \mathrm{s}$.

(2) Percepção mecânica: táctil e mecânica dolorosa: testes tácteis foram realizados através de um conjunto padronizado de filamentos de vonFrey com pontas arredondadas de $0,5 \mathrm{~mm}$ de diâmetro (IITC, WoodlandHills, EUA). Agulhas descartáveis padronizadas de $24 \mathrm{~mm}$ de comprimento e 0,40 $\mathrm{mm}$ de diâmetro foram aplicadas manualmente e perpendicularmente 
ao local avaliado para a mercepção mecânica dolorosa. As medidas foram coletadas em $\mathrm{g} / \mathrm{mm}^{2}$.

(3) Percepção dolorosa (algiometria de superfície): limiares de dor de superfície foram testados através de agulhas descartáveis de $30 \mathrm{~mm}$ de comprimento por $0,7 \mathrm{~mm}$ de diâmetro, aplicadas perpendicularmente com o auxílio de um algiômetro de superfície mecânico (Micromar®, Diadema, São Paulo, Brasil). As medidas foram coletadas em $\mathrm{g} / \mathrm{mm}^{2}$.

(4) Reflexo córneo-palpebral: utilizando-se um filamento de vonFrey padronizado de $0,05 \mathrm{~g} / \mathrm{mm}^{2}$, ambos os olhos foram testados com relação à presença do reflexo córneo-palpebral.

2. Amostra 2. A partir de Abril de 2009, os 123 doentes recrutados foram avaliados através do seguinte protocolo:

Avaliação subjetiva facial de sensibilidade: Todos os doentes e controles foram entrevistados quanto à percepção de anormalidades sensitivas faciais, que incluíam dormência e disestesia. A freqüência das anormalidades sensitivas (ausente, eventual, freqüente ou constante) e a intensidade da sensação (através da EVA) foram coletadas. Foram também incluídas queixas de anormalidades olfativas e gustativas neste protocolo.

\section{$\underline{\text { Testes sensitivos quantitativos (TSQ) }}$}

Todos os sujeitos foram submetidos a um protocolo padronizado de TSQ que consistiu em 11 testes, segundo protocolo internacional (Pigg et al., 2009), agrupados conforme se segue: 
- limiares gustativos e olfativos

- limiares de percepção térmica: frio e calor

- limiares de percepção mecânica: táctil, vibratória e elétrica

- percepção dolorosa: limiares de dor de profundidade e de superfície

- reflexo córneo-palpebral

- fluxo salivar

As áreas faciais avaliadas incluíram os três ramos trigeminais (2 $\mathrm{cm}$ acima do centro da pupila, $2 \mathrm{~cm}$ abaixo do centro da pupila e $1 \mathrm{~cm}$ abaixo da comissura labial) bilateralmente. Foram também avaliadas as áreas das palmas das mãos e região anterior da tíbia. A percepção elétrica foi também realizada nos dentes incisivos centrais e primeiros pré-molares, nos quatro quadrantes.

Todos os sujeitos foram avaliados na posição sentada, com a cabeça repousando em uma superfície lisa, em uma sala silenciosa com proteção acústica nas paredes e a porta fechada. Apenas o sujeito e o pesquisador encontravam-se na sala. Os doentes e controles foram orientados a permanecer com os olhos fechados durante todo o exame e estarem concentrados, e deveriam informar quando percebessem o estímulo e qual havia sido o estímulo aplicado.. Apenas o pesquisador sabia a ordem dos estímulos. Os sujeitos foram avaliados por dois pesquisadores distintos que haviam sido devidamente calibrados no período anterior ao do estudo. 
(1) Limiares gustativos (Siqueira et al., 2006c; Siviero et al., 2010): as seguintes quatro substâncias, correspondentes aos quatro sabores básicos, foram testadas. Para cada teste, uma gota da substância foi aplicada à língua iniciando-se na menor concentração, intercalada com uma gota de água destilada; as concentrações eram aumentadas até que o sujeito identificasse o estímulo.

- Doce: glicose: 0,01M; 0,032M; 0,1M; 0,32M; 1,0M;

- Salgado: cloreto de sódio: 0,01M; 0,032M; 0,1M; 0,32M; 1,0M;

- Azedo: ácido cítrico: 0,00032M; 0,001M; 0,0032M; 0,01M; 0,032M;

- Amargo: uréia: 0,1M; 0,32M; 1,0M; 3,2M; 10,0M.

(2)Limiares olfativos (Siqueira et al., 2006c; Siviero et al., 2010): os sujeitos foram avaliados através de solução de isopropanol em garrafas de polietileno intercaladas com garrafas de água destilada, iniciando-se com a menor concentração até o indivíduo detectar o estímulo: 0,09\%, 13,0\%, 23,0\%, 35,0\%, $53,0 \%, 70,0 \%$

(3)Percepção térmica: testes térmicos foram realizados utilizandose o equipamento MSA (Somedic, Suécia). A temperatura de base era $32^{\circ} \mathrm{C}$ e a área de contato do termodo de $9 \times 9 \mathrm{~mm}$. Os limiares de detecção de frio e calor foram obtidos através 
da variação de temperatura em uma velocidade de $1^{\circ} \mathrm{C} / \mathrm{s}$. Foram realizadas 5 medidas para cada limiar e as médias e desvios padrões foram consideradas na análise.

(2)Percepção mecânica táctil: limiares tácteis foram obtidos através de um conjunto padronizado de filamentos de vonFrey com pontas arredondadas de $0,5 \mathrm{~mm}$ de diâmetro aplicados através de um equipamento eletrônico (IITC, WoodlandHills, EUA). Três medidas em $\mathrm{g} / \mathrm{mm}^{2}$ foram realizadas em e as médias consideradas nas análises.

(3)Percepção mecânica vibratória: limiares vibratórios foram testados através do equipamento eletrônico Vibrometer (Somedic, Suécia) com um vibrador pesando $650 \mathrm{~g}$ e uma área redonda de contato de $1 \mathrm{~cm}^{2}$ utilizada perpendicularmente nos pontos avaliados, com uma variação de estímulo de $1 \mathrm{~Hz} / \mathrm{s}$. 0 método de cálculo consiste na média entre os limiares de aparecimento e desaparecimento detectados pelo sujeito.

(4)Percepção mecânica elétrica: limiares de detecção elétrica foram realizados com o equipamento eletrônico Pulpotest (Sybronendo, EUA) que apresenta uma área de contato de 1 $\mathrm{cm}^{2}$ para o estímulo e uma superfície metálica posicionada a 2 cm de distância para fechamento do circuito elétrico. O estímulo iniciava em $0 \mathrm{~A}$ e era aumentado em uma velocidade de $1 \mathrm{~A} / \mathrm{s}$ até a percepção mecânica elétrica pelo sujeito. Para a avaliação dentária, a superfície de estímulo foi posicionada na 
área vestibular do dente em avaliação, até que o sujeito percebe-se o estímulo (sensação dolorosa).

(5)Percepção dolorosa: limiares de dor de profundidade foram avaliados com um algiômetro de pressão eletrônico (Somedic, Suécia) que apresenta uma área de contato de $1 \mathrm{~cm}^{2}$ pressionada na pele com um aumento de intensidade de $50 \mathrm{kPa} / \mathrm{s}$.

(6)Percepção dolorosa (algiometria de superfície): limiares de dor de superfície foram testados com agulhas descartáveis de 30 $\mathrm{mm}$ de comprimento por $0,7 \mathrm{~mm}$ de diâmetro aplicadas através de um equipamento eletrônico (IITC, WoodlandHills, EUA) e as medidas coletadas em $\mathrm{g} / \mathrm{mm}^{2}$.

(7)Reflexo córneo-palpebral: utilizando-se um filamento de vonFrey padronizado de $0,05 \mathrm{~g} / \mathrm{mm}^{2}$, ambos os olhos foram testados com relação à presença do reflexo córneo-palpebral.

(8)Fluxo salivar: os sujeitos foram orientados a não se alimentar, mascar chicletes ou balas ou fumar nas duas horas que antecederam o teste; dois chumaços de algodão foram depositados em um pote plástico do tipo coletor universal (80 $\mathrm{mL}$ ) e pesados em uma balança de precisão (Acculab $\left.{ }^{\circledR} \mathrm{V} 1200\right)$. Após a deglutição de toda saliva pelo participante, os chumaços foram depositados no assoalho bucal, bilateralmente. $\mathrm{O}$ algodão permaneceu por cinco minutos e o 
doente ou controle não deveria deglutir nesse período. Decorrido o tempo estipulado, o conjunto de chumaços foi removido, devolvido ao pote plástico e pesado novamente. Os valores obtidos pré e pós sialometria foram anotados, sendo a diferença dividida por cinco para obterem-se as medidas em g/min (Pupo et al. 2002).

Avaliação de dor orofacial e de xerostomia: Todos os sujeitos da Amostra 2 foram avaliados através da Ficha clínica EDOF-HC (Equipe de Dor Orofacial do Hospital das Clínicas da FMUSP), para o diagnóstico de dor orofacial, que inclui: queixa principal, características principais de dor (localização, qualidade, duração, fatores de alívio, fatores de piora, intensidade EVA), cefaléia, dor generalizada, comorbidades e história médica (Siqueira e Teixeira, 2001; Siqueira et al., 2004); posteriormente, foi aplicado o Questionário para Xerostomia (Korn et al., 2002) (ANEXOS 2 e 3).

\section{Fomento}

Esta pesquisa foi apoiada pela Fundação de Amparo à Pesquisa do Estado de São Paulo (FAPESP) através dos seguintes processos: 2007/04156-4; 2008/05078-0; 2009/08697-5; 2009/13239-6; 2010/01203-4.

\section{Análise estatística}

Todos os dados foram tabulados e as freqüências, percentagens, médias, desvios e erros padrão e variações foram analisadas e comparadas. Após a avaliação descritiva inicial, as variáveis foram testadas quanto à 
distribuição através dos testes Kolmogorov-Smirnoff e gráficos Q-Q. Para as variáveis quantitativas com distribuição normal, foram utilizados os testes T de Student e ANOVA 1 fator e, quando significante, teste PostHoc de Tukey. Testes não paramétricos incluíram o teste Qui-quadrado de Pearson e o teste exato de Fisher. $\mathrm{O}$ teste $\mathrm{Z}$ foi utilizado para identificar as categorias relacionadas a diferenças estatísticas em Qui-quadrado. Correlações foram testadas entre as variáveis com o coeficiente de Pearson. O coeficiente de correlação intraclasse não foi utilizado devido aos testes não terem sido realizados nos mesmos sujeitos (Pigg et al., 2010). As duas amostras (Amostra 1 e 2) foram comparadas para verificar diferenças de resultados que poderiam se relacionar com as diferenças metodológicas empregadas. Posteriormente, a análise dos dados foi realizada através de comparações entre os grupos de doentes e controles, entre as áreas estudadas e lados do corpo. Foram calculadas as médias de cada modalidade sensitiva e comparações entre as regiões faciais e corpóreas foram realizadas. Para doentes com diagnósticos unilaterais, o lado doente foi considerado na análise no lugar de lados direito e esquerdo. Para a comparação entre as amostras, as variáveis de sensibilidade da amostra 2 correspondentes à amostra 1 foram categorizadas, exceto algiometria de supefície (por ser continua em ambas as amostras), sendo que os mesmos valores foram utilizados (0: sensibilidade normal; -1: sensibidade diminuída; -2: nenhuma sensibilidade). Para as categorias, foram utilizados os valores médios do grupo controle, sendo que o quartil de maior limiar foi dividido para os valores -1 e -2 . Todas as análises foram realizadas através do programa 
SPSS 17.0 (SPSS Inc., Illinois, EUA), considerando-se o grau de significância de $5 \%$. 


\section{RESULTADOS}

\subsection{Comparação demográfica e sensitiva entre as amostras, de acordo com a metodologia empregada $(\mathrm{N}=459)$}

Os dados relativos às características demográficas das amostras estudadas e as comparações estatísticas podem ser observados nas Tabelas 1, 2 e 3. Houve diferenças entre as amostras quanto aos diagnósticos $(p<0,001)$, lado $(p<0,001)$ e ramo trigeminal afetado $(p=0,004)$, porém idades $(p=0,846)$ e gênero $(p=0,128)$ foram semelhantes entre elas (Tabela 1).

A Tabela 2 apresenta os dados correspondentes a cada diagnóstico da Amostra 1 e a Tabela 3 apresenta os dados correspondentes a cada diagnóstico da Amostra 2. Pode-se observar que em ambas as amostras houve diferenças nas características de idade $(p=0,020$ e $p=0,007$ respectivamente), gênero $(p<0,001$ e $p=0,005$ respectivamente), lado $(p<0,001)$ e ramo trigeminal afetado $(p<0,001)$ entre os diagnósticos. 
Tabela 1 - Características demográficas das amostras estudadas $(\mathrm{N}=459)$

\begin{tabular}{|c|c|c|c|c|}
\hline & $\begin{array}{c}\text { Amostra } 1 \\
(\mathrm{~N}=336)\end{array}$ & $\begin{array}{c}\text { Amostra } 2 \\
(\mathrm{~N}=123)\end{array}$ & $\begin{array}{l}\text { TOTAL } \\
(\mathrm{N}=459)\end{array}$ & $\mathbf{p}^{*}$ \\
\hline $\begin{array}{l}\text { Idades } \\
\text { (anos) }\end{array}$ & $\begin{array}{c}56,19 \pm 14,53 \\
(16 \text { a } 85)\end{array}$ & $\begin{array}{c}57,93 \pm 19,38 \\
(14 \text { a } 88)\end{array}$ & $\begin{array}{c}56,70 \pm 16,09 \\
(14 \text { a } 88)\end{array}$ & 0,846 \\
\hline \multirow[t]{6}{*}{ Gênero (\%) } & $\begin{array}{c}206(61,3) \\
\text { mulheres }\end{array}$ & $\begin{array}{l}88(71,5) \\
\text { Mulheres }\end{array}$ & $\begin{array}{l}293(63,8) \\
\text { Mulheres }\end{array}$ & \multirow[t]{6}{*}{0,128} \\
\hline & $162(48,2) \mathrm{NIT}^{* *}$ & $29(23,6)$ NIT & $191(41,6)$ NIT & \\
\hline & $5(1,5)$ DTM & $11(8,9)$ DTM & $15(32,7)$ DTM & \\
\hline & $11(3,3) \mathrm{SAB}$ & $8(6,5) S A B$ & $19(4,1) \mathrm{SAB}$ & \\
\hline & $30(8,9)$ DFIP & $8(6,5)$ DFIP & $38(8,3)$ DFIP & \\
\hline & $5(1,5)$ fibromialgia & $8(6,5)$ fibromialgia & $13(2,8)$ fibromialgia & \\
\hline \multirow{7}{*}{$\begin{array}{l}\text { Diagnósticos } \\
\text { (\%) }\end{array}$} & $18(5,4) \mathrm{NPH}$ & $6(4,9) \mathrm{NPH}$ & $24(5,2) \mathrm{NPH}$ & \multirow{7}{*}{$<0,001$} \\
\hline & $19(5,7) \mathrm{NPT}$ & $5(4,1) \mathrm{NPT}$ & $24(5,2) \mathrm{NPT}$ & \\
\hline & $2(0,6) \mathrm{CC}$ & $2(1,6) \mathrm{CC}$ & $4(0,8) \mathrm{CC}$ & \\
\hline & $30(8,9) \mathrm{ND}$ & $0(0,0) \mathrm{ND}$ & $30(6,5) \mathrm{ND}$ & \\
\hline & $0(0,0) \mathrm{PF}$ & $3(2,4)$ PF & $3(0,6) \mathrm{PF}$ & \\
\hline & $0(0,0) \mathrm{SW}$ & $2(1,6) \mathrm{SW}$ & $2(0,4) S W$ & \\
\hline & $54(16,1)$ controles & $41(33,3)$ controles & $95(20,7)$ controles & \\
\hline \multirow{6}{*}{$\begin{array}{l}\text { Lado da dor } \\
(\%)\end{array}$} & $139(41,4)$ direito & $34(27,6)$ direito & $177(38,6)$ direito & \multirow{6}{*}{$<0,001$} \\
\hline & $89(26,5)$ esquerdo & $29(23,6)$ esquerdo & $118(25,7)$ esquerdo & \\
\hline & $54(16,1)$ bilateral & $19(15,4)$ bilateral & $69(15,0)$ bilateral & \\
\hline & $18(5,4) \vee 1^{* * *}$ & $6(4,9) \vee 1$ & $24(5,2) \mathrm{V} 1$ & \\
\hline & $52(15,5) \vee 2$ & $10(8,1) \mathrm{V} 2$ & $62(13,5) \mathrm{V} 2$ & \\
\hline & $44(13,1) \vee 3$ & $13(10,6) \vee 3$ & $57(12,4) \vee 3$ & \\
\hline Ramo & $15(4,5) \vee 1-2$ & $1(0,8) \vee 1-2$ & $16(3,5) \vee 1-2$ & \multirow{5}{*}{0,004} \\
\hline \multirow[t]{4}{*}{ afetado (\%) } & $42(12,5)$ V2-3 & $9(7,3) \vee 2-3$ & $52(11,3)$ V2-3 & \\
\hline & $8(2,4)$ V1-2-3 & $2(1,6) \vee 1-2-3$ & $10(2,2) \vee 1-2-3$ & \\
\hline & $1(0,3) \vee 1-3$ & $0(0,0) \vee 1-3$ & $1(0,2) \vee 1-3$ & \\
\hline & $102(30,3)$ nenhum & $39(31,7)$ nenhum & $140(30,5)$ nenhum & \\
\hline
\end{tabular}

$\left(^{*}\right) \quad$ Testes Qui-quadrado de Pearson e exato de Fisher.

${ }^{* *}$ NIT: Neuralgia Idiopática do Trigêmeo; DTM: Disfunção Temporomandibular; SAB: Síndrome da Ardência Bucal; DFIP: Dor Facial Idiopática Persistente; NPH: Neuralgia Pós-herpética; NPT: Neuropatia Pós-traumática; PF: Paralisia Facial; CC: Cefaléia Cervicogênica; SW: Síndrome de Wallemberg; ND: Neuropatia Diabética

${ }^{* * *}$ V1: ramo oftálmico; V2: ramo maxilar; V3: ramo mandibular; V1-2: ramos oftálmico e maxilar; V2-3: ramos maxilar e mandibular; V1-2-3: ramos oftálmico, maxilar e mandibular; V1-3: ramos oftálmico e mandibular 
Tabela 2 - $\quad$ Características da amostra 1 de acordo com o diagnóstico $(\mathrm{N}=336)$

\begin{tabular}{|c|c|c|c|c|}
\hline & $\begin{array}{l}\text { Idades } \\
\text { (Anos) }\end{array}$ & Gênero (\%) & $\begin{array}{c}\text { Lado afetado } \\
(\%)\end{array}$ & $\begin{array}{c}\text { Ramo } \\
\text { afetado (\%) }\end{array}$ \\
\hline $\begin{array}{l}\text { NIT } \\
(\mathrm{N}=162)^{\star *}\end{array}$ & $\begin{array}{c}60,51 \pm 11,91 \\
(34-85)\end{array}$ & $\begin{array}{l}88(54,3) \\
\text { mulheres }\end{array}$ & $\begin{array}{c}101(62,3) \text { direito } \\
60(37,0) \\
\text { esquerdo } \\
01(0,6) \text { bilateral }\end{array}$ & $\begin{array}{c}6(3,7) \vee 1^{* * *} \\
50(30,9) \vee 2 \\
44(27,2) \vee 3 \\
14(8,6) \bigvee 1-2 \\
40(24,7) \vee 2-3 \\
7(4,3) \vee 1-2-3 \\
1(0,6) \vee 1-3\end{array}$ \\
\hline DTM $(N=5)$ & $\begin{array}{l}47,50 \pm 6,84 \\
\quad(41-56)\end{array}$ & 5 (100) mulheres & $\begin{array}{c}3(60,0) \text { direito } \\
2(40,0) \text { esquerdo }\end{array}$ & - \\
\hline $\mathrm{SAB}(\mathrm{N}=11)$ & $\begin{array}{l}54,25 \pm 8,63 \\
\quad(35-61)\end{array}$ & $11(100)$ mulheres & $\begin{array}{c}11(100,0) \\
\text { bilateral }\end{array}$ & - \\
\hline $\mathrm{DFIP}(\mathrm{N}=30)$ & $\begin{array}{c}43,80 \pm 17,46 \\
(23-76)\end{array}$ & $\begin{array}{l}29(96,7) \\
\text { mulheres }\end{array}$ & $\begin{array}{c}14(46,7) \text { direito } \\
10(33,3) \\
\text { esquerdo } \\
6(20,0) \text { bilateral }\end{array}$ & - \\
\hline $\begin{array}{l}\text { Fibromialgia } \\
(\mathrm{N}=5)\end{array}$ & $\begin{array}{c}43,50 \pm 12,02 \\
(35-52)\end{array}$ & $4(80,0)$ mulheres & $\begin{array}{c}5(100,00) \\
\text { bilateral }\end{array}$ & - \\
\hline $\mathrm{NPH}(\mathrm{N}=18)$ & $\begin{array}{l}71,33 \pm 8,16 \\
\quad(55-82)\end{array}$ & $\begin{array}{l}12(66,7) \\
\text { mulheres }\end{array}$ & $\begin{array}{c}14(77,8) \text { direito } \\
4(22,2) \text { esquerdo }\end{array}$ & $\begin{array}{l}12(66,7) \vee 1 \\
2(11,1) \vee 2 \\
1(5,6) \vee 1-2 \\
2(11,1) \vee 2-3 \\
1(5,6) \vee 1-2-3\end{array}$ \\
\hline NPT (N=19) & $\begin{array}{c}47,94 \pm 14,74 \\
(32-83)\end{array}$ & $\begin{array}{l}14(73,7) \\
\text { mulheres }\end{array}$ & $\begin{array}{c}5(26,3) \text { direito } \\
13(68,4) \\
\text { esquerdo } \\
1(5,3) \text { bilateral }\end{array}$ & - \\
\hline $\mathrm{CC}(\mathrm{N}=2)$ & $\begin{array}{l}40,00 \pm 0,00 \\
(40)\end{array}$ & $1(50,0)$ mulher & $2(100)$ direito & - \\
\hline $\mathrm{ND}(\mathrm{N}=30)$ & $\begin{array}{l}57,67 \pm 9,26 \\
\quad(37-77)\end{array}$ & $\begin{array}{l}12(40,0) \\
\text { mulheres }\end{array}$ & $\begin{array}{c}30(100,0) \\
\text { bilateral }\end{array}$ & - \\
\hline $\begin{array}{l}\text { Controle } \\
(\mathrm{N}=54)\end{array}$ & $\begin{array}{c}45,67 \pm 15,07 \\
(16-75)\end{array}$ & $\begin{array}{l}30(55,6) \\
\text { mulheres }\end{array}$ & - & - \\
\hline $\mathbf{p}^{*}$ & 0,020 & $<0,001$ & $<0,001$ & $<0,001$ \\
\hline \multicolumn{5}{|c|}{$\begin{array}{l}\text { Testes Qui-quadrado de Pearson e exato de Fisher } \\
\text { NIT: Neuralgia Idiopática do Trigêmeo; DTM: Disfunção Temporomandibular; SAB: } \\
\text { Síndrome da Ardência Bucal; DFIP: Dor Facial Idiopática Persistente; NPH: } \\
\text { Neuralgia Pós-herpética; NPT: Neuropatia Pós-traumática; CC: Cefaléia } \\
\text { Cervicogênica; ND: Neuropatia diabética }\end{array}$} \\
\hline $\begin{array}{l}\text { V1: ra } \\
\text { maxil } \\
\text { mand }\end{array}$ & $\begin{array}{l}\text { oftálmico; V2 } \\
\text { V2-3-: ramos } \\
\text { ular; V1-3: ramc }\end{array}$ & $\begin{array}{l}\text { ramo maxilar; V3: ra } \\
\text { maxilar e mandibul } \\
\text { oftálmico e mandib }\end{array}$ & no mandibular; V1-2 & $\begin{array}{l}\text { amos oftálmico e } \\
\text { almico, maxilar e }\end{array}$ \\
\hline
\end{tabular}


Tabela 3 - Características gerais da amostra 2 de acordo com 0 diagnóstico $(\mathrm{N}=123)$

\begin{tabular}{|c|c|c|c|c|}
\hline & $\begin{array}{l}\text { Idades } \\
\text { (Anos) }\end{array}$ & Gênero (\%) & $\begin{array}{c}\text { Lado afetado } \\
(\%)\end{array}$ & $\begin{array}{c}\text { Ramo } \\
\text { afetado (\%) }\end{array}$ \\
\hline NIT $(\mathrm{N}=29)$ & $\begin{array}{c}60,69 \pm 14,83 \\
(29-87)\end{array}$ & $22(75,9)$ mulheres & $\begin{array}{l}18(62,1) \text { direito } \\
11(37,9) \\
\text { esquerdo }\end{array}$ & $\begin{array}{c}1(3,4) \vee 1 \\
9(31,0) \vee 2 \\
9(31,0) \vee 3 \\
8(27,6) \bigvee 2-3 \\
2(6,9) \vee 1-2-3\end{array}$ \\
\hline DTM $(N=11)$ & $\begin{array}{c}43,64 \pm 17,82 \\
(23-69)\end{array}$ & $\begin{array}{l}11(100,0) \\
\text { mulheres }\end{array}$ & $\begin{array}{c}2(18,2) \text { direito } \\
6(54,5) \text { esquerdo } \\
3(27,3) \text { bilateral }\end{array}$ & - \\
\hline $\mathrm{SAB}(\mathrm{N}=8)$ & $\begin{array}{c}67,00 \pm 16,69 \\
(37-88)\end{array}$ & $8(100,0)$ mulheres & $8(100,0)$ bilateral & - \\
\hline DFIP $(N=8)$ & $\begin{array}{c}44,63 \pm 19,09 \\
(14-73)\end{array}$ & $7(87,5)$ mulheres & $\begin{array}{c}5(62,5) \text { direito } \\
3(37,5) \text { esquerdo }\end{array}$ & \\
\hline $\begin{array}{l}\text { Fibromialgia } \\
(\mathrm{N}=8)\end{array}$ & $\begin{array}{l}47,00 \pm 1,16 \\
(31-73)\end{array}$ & $8(100,0)$ mulheres & $8(100,0)$ bilateral & - \\
\hline $\mathrm{NPH}(\mathrm{N}=6)$ & $\begin{array}{c}72,17 \pm 10,80 \\
(56-84)\end{array}$ & $4(66,7)$ mulheres & $\begin{array}{c}2(33,3) \text { direito } \\
4(66,7) \text { esquerdo }\end{array}$ & $\begin{array}{c}5(83,4) \vee 1 \\
1(16,7) \vee 1-2\end{array}$ \\
\hline $\mathrm{NPT}(\mathrm{N}=5)$ & $\begin{array}{c}35,00 \pm 20,84 \\
(15-58)\end{array}$ & $5(100,0)$ mulheres & $\begin{array}{c}2(40,0) \text { direito } \\
3(60,0) \text { esquerdo }\end{array}$ & $\begin{array}{c}1(20,0) \text { V2 } \\
4(80,0) \text { V3 } \\
1(20,0) \text { V2-3 }\end{array}$ \\
\hline $\mathrm{CC}(\mathrm{N}=2)$ & $\begin{array}{c}70,50 \pm 10,61 \\
(63-78)\end{array}$ & $1(50,0)$ mulher & $\begin{array}{c}1(50,0) \text { direito } \\
1(50,0) \text { esquerdo }\end{array}$ & - \\
\hline$P F(N=2)$ & $\begin{array}{c}51,33 \pm 12,22 \\
(38-62)\end{array}$ & $2(66,7)$ mulheres & $3(100,0)$ direito & - \\
\hline $\mathrm{SW}(\mathrm{N}=2)$ & $\begin{array}{c}46,50 \pm 6(44- \\
49)\end{array}$ & $1(50,0)$ mulher & $\begin{array}{c}1(50,0) \text { direito } \\
1(50,0) \text { esquerdo }\end{array}$ & - \\
\hline $\begin{array}{l}\text { Controle } \\
(\mathrm{N}=41)\end{array}$ & $\begin{array}{c}63,90 \pm 20,33 \\
(15-87)\end{array}$ & $19(46,3)$ mulheres & - & - \\
\hline$p^{*}$ & 0,007 & 0,005 & $<0,001$ & $<0,001$ \\
\hline \multicolumn{5}{|c|}{$\begin{array}{l}\text { Testes Qui-quadrado de Pearson e exato de Fisher } \\
\text { NIT: Neuralgia Idiopática do Trigêmeo; DTM: Disfunção Temporomandibular; SAB: } \\
\text { Síndrome da Ardência Bucal; DFIP: Dor Facial Idiopática Persistente; NPH: } \\
\text { Neuralgia Pós-herpética; NPT: Neuropatia Pós-traumática; PF: Paralisia Facial; CC: } \\
\text { Cefaléia Cervicogênica; SW: Síndrome de Wallemberg }\end{array}$} \\
\hline $\begin{array}{l}\mathrm{V} 1: \mathrm{ra} \\
\text { maxil } \\
\text { mand }\end{array}$ & $\begin{array}{l}\text { oftálmico; V2: } \\
\text { V2-3-: ramos } \\
\text { lar }\end{array}$ & $\begin{array}{l}\text { amo maxilar; V3: ram } \\
\text { naxilar e mandibular }\end{array}$ & $\begin{array}{l}\text { mandibular; } \mathrm{V} 1-2 \text { : } \\
\text { V1-2-3: ramos oftá }\end{array}$ & $\begin{array}{l}\text { mos oftálmico e } \\
\text { mico, maxilar e }\end{array}$ \\
\hline
\end{tabular}


As amostras 1 e 2 foram comparadas quanto às mesmas características (idade, gênero, lado e ramo trigeminal afetado) entre os subgrupos de diagnóstico (Tabela 4). Houve diferença quanto ao gênero dos doentes com NIT $(p=0,023)$ e de lado afetado dos doentes com NPH $(P=0,015)$ entre as amostras estudadas.

Tabela 4 - Diferenças entre as amostras quanto às características gerais para cada diagnóstico $(\mathrm{N}=459)$

\begin{tabular}{lcccc}
\hline & Idades $\left(\mathbf{p}^{*}\right)$ & Gênero $(\mathbf{p})$ & $\begin{array}{c}\text { Lado afetado } \\
(\mathbf{p})\end{array}$ & $\begin{array}{c}\text { Ramo afetado } \\
(\mathbf{p})\end{array}$ \\
\hline NIT & 0,135 & $\mathbf{0 , 0 2 3}$ & 0,912 & 0,777 \\
DTM & 0,411 & $* * *$ & 0,089 & 0,259 \\
SAB & 0,301 & 0,421 & 0,421 & - \\
DFIP & 0,190 & 0,381 & 0,723 & 0,211 \\
Fibromialgia & $* * *$ & $* * *$ & - & - \\
NPH & 0,242 & 0,698 & $\mathbf{0 , 0 1 5}$ & 0,377 \\
NPT & $* * *$ & $* * *$ & - & - \\
CC & $* * *$ & $* * *$ & $* * *$ & $*$ \\
Controle & 0,280 & 0,208 & - & -
\end{tabular}

$\left(^{*}\right) \quad$ Testes Qui-quadrado de Pearson e exato de Fisher

${ }^{* *}$ NIT: Neuralgia Idiopática do Trigêmeo; DTM: Disfunção Temporomandibular; SAB: Síndrome da Ardência Bucal; DFIP: Dor Facial Idiopática Persistente; NPH: Neuralgia Pós-herpética; NPT: Neuropatia Pós-traumática; CC: Cefaléia Cervicogênica

${ }^{* * *}$ Estatística não pode ser realizada por haver uma constância da variável na amostra

Houve diferença significante entre as amostras estudadas quanto à prevalência e frequência de dormência $(p<0,001)$, porém intensidade de dormência e disestesia foram semelhantes (Tabela 5). A Tabela 6 mostra as diferenças entre os sujeitos avaliados de acordo com os diagnósticos. Os doentes com NPH apresentaram maior prevalência de dormência $(p<0,001)$; a freqüência foi maior em NPH, NPT e DTM $(p<0,001)$. A intensidade de 
dormência foi maior em SAB $(p=0,034)$ e disestesia foi mais intensa em SAB e DFIP $(p=0,020)$.

Tabela 5 - Características subjetivas faciais de sensibilidade: freqüências e intensidades de dormência e disestesia de acordo com a amostra estudada $(\mathrm{N}=459)$

\begin{tabular}{lcccc}
\hline & $\begin{array}{c}\text { Amostra 1 } \\
(\mathbf{N}=336)\end{array}$ & $\begin{array}{c}\text { Amostra 2 } \\
(\mathbf{N}=123)\end{array}$ & $\begin{array}{c}\text { TOTAL } \\
(\mathbf{N}=459)\end{array}$ & $\mathbf{p}^{*}$ \\
\hline $\begin{array}{l}\text { Prevalência } \\
\text { de dormência } \\
\text { (\%) }\end{array}$ & $179(52,3)$ & $102(82,9)$ & $281(61,2)$ & $<\mathbf{0 , 0 0 1}$ \\
Freqüência & $128(38,1)$ & $3(2,4)$ constante & $131(28,5)$ & $<0,001$ \\
de dormência & constante & $17(13,8)$ & constante & \\
(\%) & $29(8,6)$ freqüente & freqüente & $46(10,0)$ & \\
& $22(6,5)$ eventual & $82(66,7)$ & freqüente & \\
& & eventual & $104(22,7)$ & \\
& & & eventual & \\
IMDO & $6,14 \pm 2,42(1-10)$ & $6,60 \pm 2,71(1-10)$ & $6,26 \pm 2,50(1-10)$ & 0,314 \\
IMDI & $6,81 \pm 2,50(1-10)$ & $7,75 \pm 2,76(1-10)$ & $7,07 \pm 2,60(1-10)$ & 0,065
\end{tabular}

$\left(^{*}\right)$ Testes Qui-quadrado de Pearson, exato de Fisher e teste T de Student.

$\left.{ }^{* *}\right) \quad$ IMDO: Intensidade média de dormência; IMDI: Intensidade média de disestesia 
Tabela 6 - Características subjetivas de sensibilidade: freqüências e intensidades de dormência e disestesia na região facial de acordo com os diagnósticos ( $\mathrm{N}=459)$

\begin{tabular}{|c|c|c|c|c|}
\hline & $\begin{array}{l}\text { Prevalência de } \\
\text { dormência (\%) }\end{array}$ & $\begin{array}{l}\text { Freqüência de } \\
\text { dormência (\%) }\end{array}$ & $\begin{array}{l}\text { Intensidade } \\
\text { média de } \\
\text { dormência }\end{array}$ & $\begin{array}{l}\text { Intensidade } \\
\text { média de } \\
\text { disestesia }\end{array}$ \\
\hline NIT & $123(64,4)$ & $\begin{array}{l}77(40,3) \text { constante } \\
24(12,6) \text { freqüente } \\
22(11,5) \text { eventual }\end{array}$ & $\begin{array}{c}5,47 \pm, 60 \\
(1-10)\end{array}$ & $\begin{array}{c}6,63 \pm 2,80 \\
(1-10)\end{array}$ \\
\hline DTM & $13(86,6)$ & $\begin{array}{c}1(6,3) \text { constante } \\
6(37,5) \text { freqüente } \\
6(37,5) \text { eventual }\end{array}$ & $\begin{array}{c}7,00 \pm 1,60 \\
(5-10)\end{array}$ & $\begin{array}{c}8,75 \pm 1,58 \\
(6-10)\end{array}$ \\
\hline$S A B$ & $11(57,9)$ & $\begin{array}{l}3(15,8) \text { constante } \\
8(42,1) \text { eventual }\end{array}$ & $\begin{array}{c}8,43 \pm 1,90 \\
(5-10)\end{array}$ & $\begin{array}{c}8,43 \pm 2,37 \\
\quad(5-10)\end{array}$ \\
\hline DFIP & $20(52,6)$ & $\begin{array}{c}12(31,6) \text { constante } \\
2(5,3) \text { freqüente } \\
6(15,8) \text { eventual }\end{array}$ & $\begin{array}{c}7,16 \pm 2,41 \\
(2-10)\end{array}$ & $\begin{array}{c}8,31 \pm 1,66 \\
(4-10)\end{array}$ \\
\hline ND & $7(23,3)$ & $\begin{array}{l}1(3,3) \text { constante } \\
1(3,3) \text { freqüente } \\
5(16,7) \text { eventual }\end{array}$ & $\begin{array}{c}5,75 \pm 2,98 \\
(3-10)\end{array}$ & $\begin{array}{c}5,25 \pm 1,26 \\
(4-7)\end{array}$ \\
\hline Fibromialgia & $8(61,5)$ & $\begin{array}{c}3(23,1) \text { constante } \\
2(15,4) \text { freqüente } \\
3(23,1) \text { eventual }\end{array}$ & $\begin{array}{c}4,50 \pm 3,53 \\
(2-7)\end{array}$ & $\begin{array}{c}3,67 \pm 3,79 \\
(1-8)\end{array}$ \\
\hline NPH & $22(91,7)$ & $\begin{array}{c}8(33,3) \text { constante } \\
5(20,8) \text { frequente } \\
9(37,5) \text { eventual }\end{array}$ & $\begin{array}{c}5,56 \pm 2,50 \\
(1-10)\end{array}$ & $\begin{array}{c}5,50 \pm 2,58 \\
(2-10)\end{array}$ \\
\hline NPT & $19(79,2)$ & $\begin{array}{c}15(62,4) \text { constante } \\
2(8,2) \text { freqüente } \\
2(8,2) \text { eventual }\end{array}$ & $\begin{array}{c}6,32 \pm 2,17 \\
(2-10)\end{array}$ & $\begin{array}{c}7,75 \pm 2,29 \\
(1-10)\end{array}$ \\
\hline CC & $4(100,0)$ & $\begin{array}{l}1(25,0) \text { constante } \\
1(25,0) \text { freqüente } \\
2(50,0) \text { eventual }\end{array}$ & $\begin{array}{c}6,00 \pm 0,00 \\
(6)\end{array}$ & $\begin{array}{c}6,00 \pm 0,00 \\
(6)\end{array}$ \\
\hline PF & $2(66,7)$ & $\begin{array}{c}1(33,3) \text { freqüente } \\
1(33,3) \text { eventual }\end{array}$ & $\begin{array}{c}7,00 \pm 2,82 \\
(5-9)\end{array}$ & $\begin{array}{c}7,50 \pm 3,53 \\
(5-10)\end{array}$ \\
\hline sw & $1(50,0)$ & $1(50,0)$ eventual & $5,00 \pm 0,00(5)$ & $5,00 \pm 0,00(5)$ \\
\hline Controle & $46(48,4)$ & $\begin{array}{c}1(1,1) \text { constante } \\
6(6,3) \text { freqüente } \\
39(41,1) \text { eventual }\end{array}$ & $\begin{array}{c}8,00 \pm 2,00 \\
(5-10)\end{array}$ & $\begin{array}{c}7,83 \pm 1,94 \\
(5-10)\end{array}$ \\
\hline $\mathbf{p}^{*}$ & $<0,001$ & $<0,001$ & 0,034 & 0,020 \\
\hline
\end{tabular}

( $^{*}$ Testes Qui-quadrado de Pearson, exato de Fisher e teste T de Student. Teste Z indicou maior prevalência de dormência em NPH e menor em ND. Houve maior freqüência de dormência em NPH, NPT e DTM e menor em ND e controle. Teste de Tukey indicou maior intensidade de dormência em SAB e maior intensidade de disestesia em SAB e DFIP.

${ }^{* *}$ NIT: Neuralgia Idiopática do Trigêmeo; DTM: Disfunção Temporomandibular; SAB: Síndrome da Ardência Bucal; DFIP: Dor Facial Idiopática Persistente; ND: Neuropatia diabética; NPH: Neuralgia Pós-herpética; NPT: Neuropatia Pós-traumática; CC: Cefaléia Cervicogênica; PF: Paralisia facial; SW: Síndrome de Wallemberg. 


\subsection{Testes sensitivos quantitativos (TSQ) $(\mathrm{N}=459)$}

Inicialmente, as variáveis quantitativas contínuas de sensibilidade utilizadas na amostra 2 foram categorizadas para efeito comparativo com os dados da amostra 1. A análise individual dos dados da amostra 2 na forma quantitativa contínua foi posteriormente avaliada e encontra-se apresentada num próximo capítulo. Os resultados podem ser observados nas Figuras 1 a 5. Houve diferenças entre as amostras e entre os lados afetado/direito e controle/esquerdo na amostra 1 nas sensibilidades ao frio $(p<0,001)$, ao calor $(p<0,001)$, mecânica táctil $(p<0,001)$ e mecânica dolorosa $(p<0,001)$. A algiometria de superfície não apresentou diferenças entre as amostras, porém os limiares do ramo maxilar esquerdo foram menores quando comparados aos limiares ipsilaterais dos ramos oftálmico e mandibular na amostra $1(p=0,036)$. 
Figura 1 - Avaliação sensitiva quantitativa térmica (frio): comparação entre as amostras para cada ramo trigeminal $(\mathrm{N}=459)$

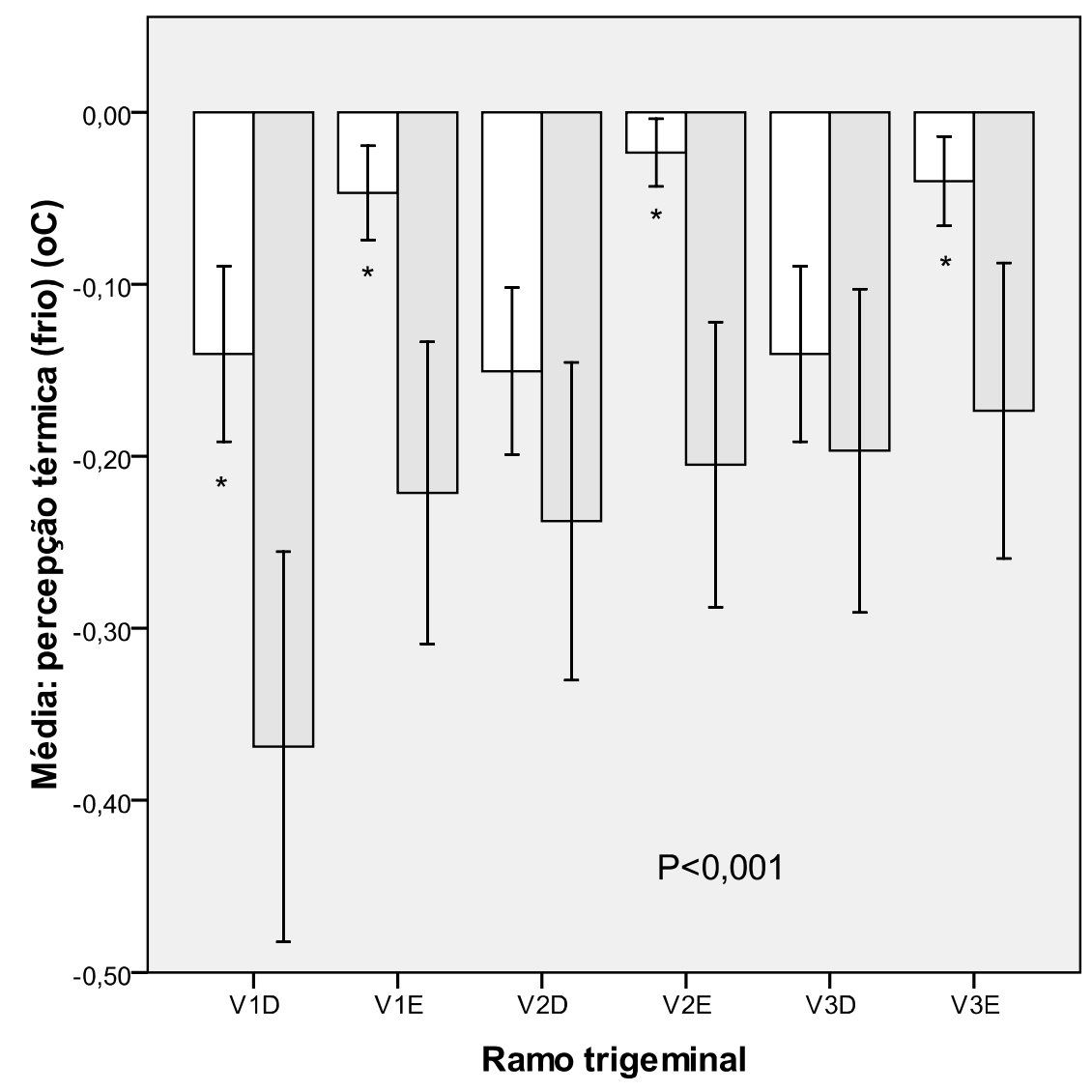

Amostra

$\square$ Amostra 1

$\left(^{*}\right) \quad$ Teste ANOVA 1 fator, PostHoc: teste de Tukey. As barras correspondem ao intervalo de confiança $95 \%$

$\left({ }^{* *}\right) \quad$ V1D: ramo oftálmico direito; V1E: ramo oftálmico esquerdo; V2D: ramo maxilar direito; V2E: ramo maxilar esquerdo; V3D: ramo mandibular direito; V3E: ramo mandibular esquerdo. 
Figura 2 - $\quad$ Avaliação sensitiva quantitativa térmica (calor): comparação entre as amostras para cada ramo trigeminal $(\mathrm{N}=459)$

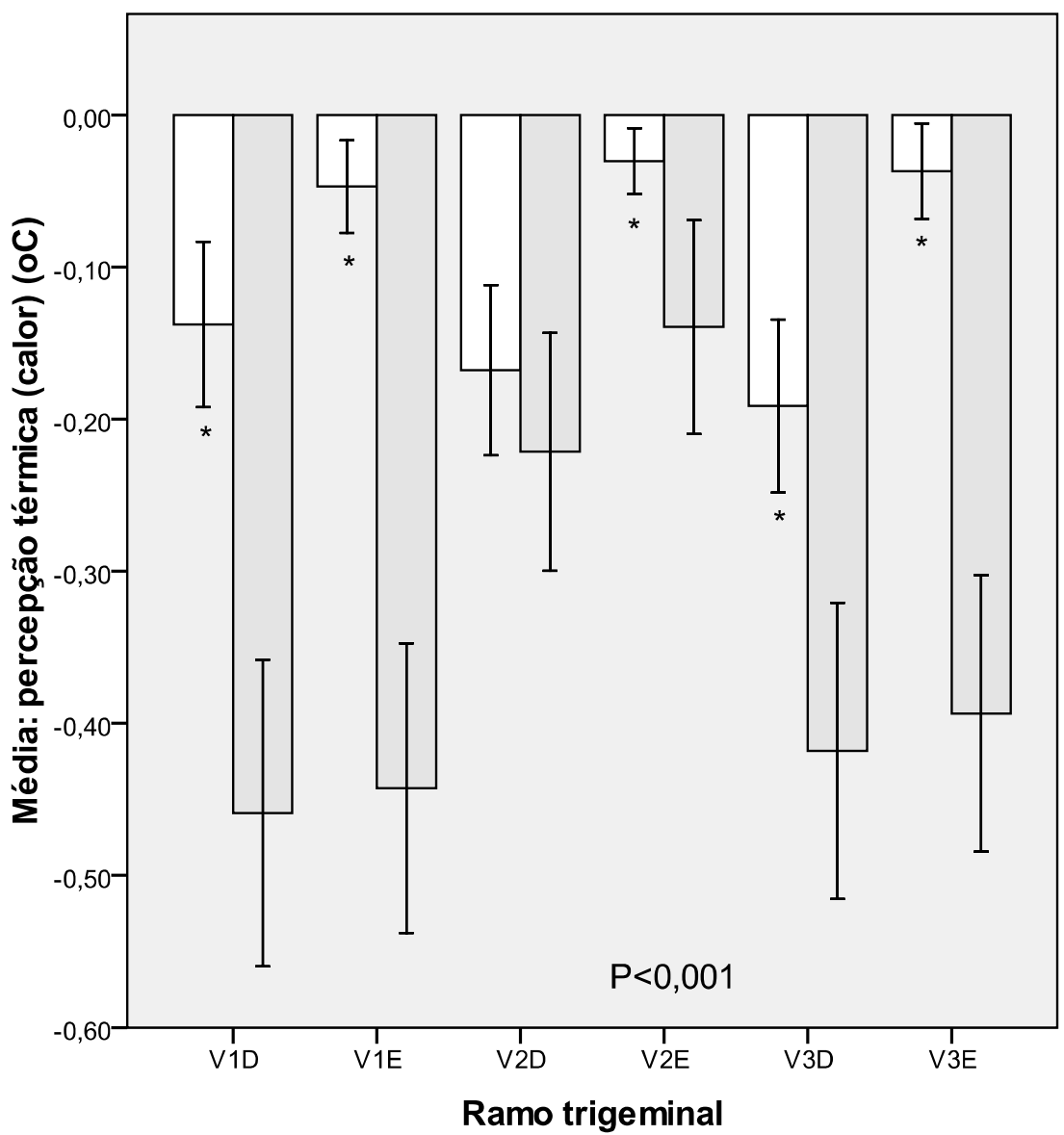

Amostra

$\square$ Amostra 1

$\square$ Amostra 2

$\left(^{*}\right) \quad$ Teste ANOVA 1 fator, PostHoc: teste de Tukey. As barras correspondem ao intervalo de confiança $95 \%$

$\left({ }^{* *}\right) \quad$ V1D: ramo oftálmico direito; V1E: ramo oftálmico esquerdo; V2D: ramo maxilar direito; V2E: ramo maxilar esquerdo; V3D: ramo mandibular direito; V3E: ramo mandibular esquerdo. 
Figura 3 - $\quad$ Avaliação sensitiva quantitativa mecânica táctil: comparação entre as amostras para cada ramo trigeminal $(\mathrm{N}=459)$

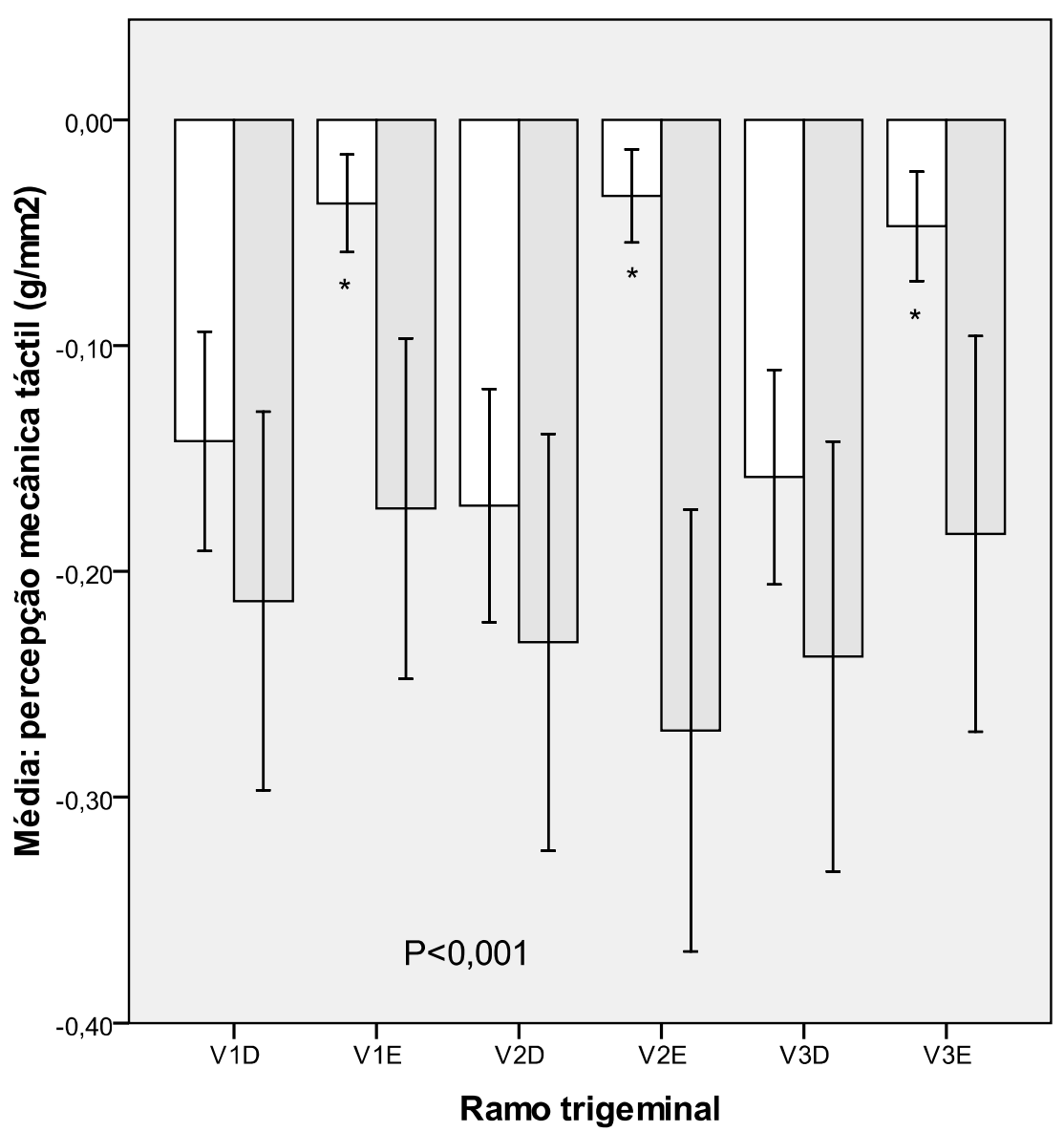

Amostra

$\square$ Amostra 1

$\square$ Amostra 2

$\left(^{*}\right) \quad$ Teste ANOVA 1 fator, PostHoc: teste de Tukey. As barras correspondem ao intervalo de confiança $95 \%$

${ }^{* *}$ V1D: ramo oftálmico direito; V1E: ramo oftálmico esquerdo; V2D: ramo maxilar direito; V2E: ramo maxilar esquerdo; V3D: ramo mandibular direito; V3E: ramo mandibular esquerdo. 
Figura 4 - Avaliação sensitiva quantitativa mecânica dolorosa: comparação entre as amostras para cada ramo trigeminal $(\mathrm{N}=459)$

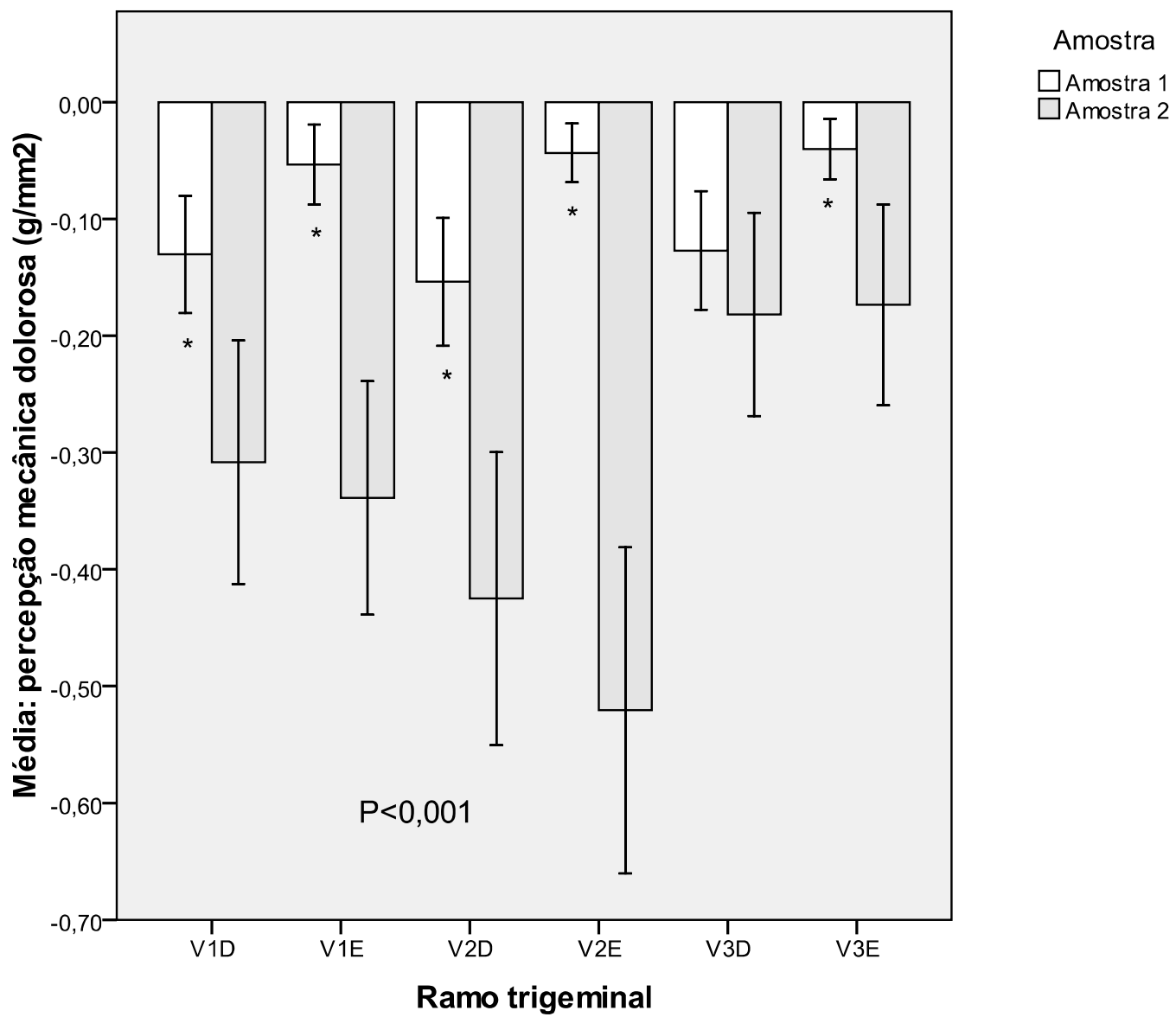

$\left.{ }^{*}\right)$ Teste ANOVA 1 fator, PostHoc: teste de Tukey. As barras correspondem ao intervalo de confiança $95 \%$

$\left.{ }^{* *}\right)$ V1D: ramo oftálmico direito; V1E: ramo oftálmico esquerdo; V2D: ramo maxilar direito; V2E: ramo maxilar esquerdo; V3D: ramo mandibular direito; V3E: ramo mandibular esquerdo. 
Figura 5 - Avaliação sensitiva quantitativa dolorosa de superfície: comparação entre as amostras para cada ramo trigeminal $(\mathrm{N}=459)$

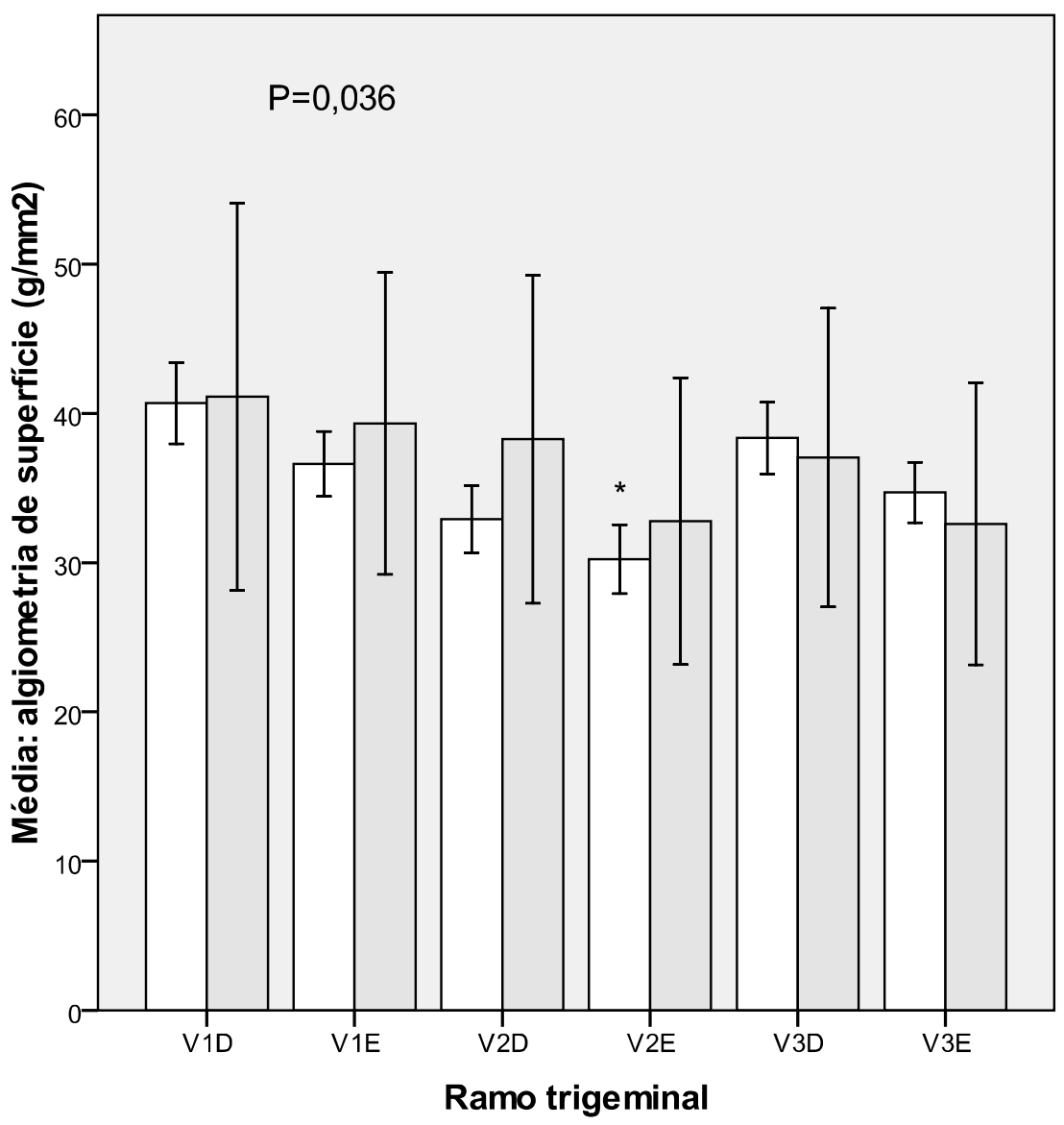

Amostra

$\square$ Amostra 1

$\square$ Amostra 2

$\left(^{*}\right) \quad$ Teste ANOVA 1 fator, PostHoc: teste de Tukey. As barras correspondem ao intervalo de confiança $95 \%$

${ }^{* *}$ V1D: ramo oftálmico direito; V1E: ramo oftálmico esquerdo; V2D: ramo maxilar direito; V2E: ramo maxilar esquerdo; V3D: ramo mandibular direito; V3E: ramo mandibular esquerdo.

Após a análise inicial comparativa entre as amostras, as variáveis

de sensibilidade foram estudadas de acordo com o diagnóstico. $\mathrm{Na}$ percepção térmica ao frio, os limiares do ramo oftálmico afetado/direito foram maiores em NPH e SAB $(p<0,001)$, assim como no ramo oftálmico oposto/esquerdo ( $p=0,001)$ quando comparados aos controles (Figura 6). 
Figura 6 - $\quad$ Avaliação sensitiva quantitativa térmica (frio): comparação entre os diagnósticos para o ramo oftálmico $(\mathrm{N}=459)$
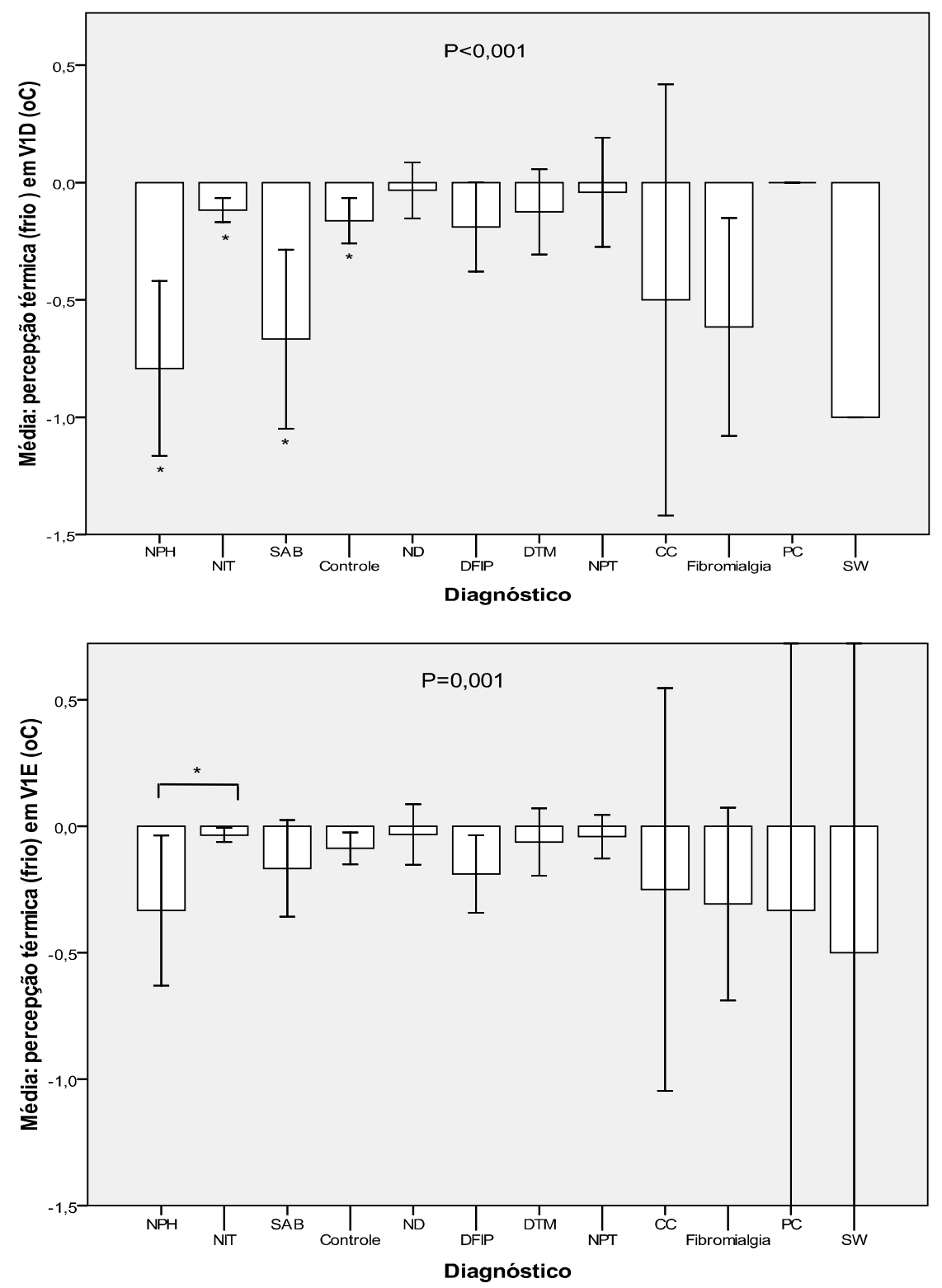

(*) Teste ANOVA 1 fator, PostHoc: teste de Tukey. As barras correspondem ao intervalo de confiança $95 \%$

${ }^{* *}$ NIT: Neuralgia Idiopática do Trigêmeo; DTM: Disfunção Temporomandibular; SAB: Síndrome da Ardência Bucal; DFIP: Dor Facial Idiopática Persistente; ND: Neuropatia diabética; NPH: Neuralgia Pós-herpética; NPT: Neuropatia Póstraumática; CC: Cefaléia Cervicogênica; PF: Paralisia facial; SW: Síndrome de Wallemberg

$\left.{ }^{(* \star}\right)$ V1D: ramo oftálmico direito; VIE: ramo oftálmico esquerdo

Os doentes com SAB apresentaram limiares maiores de percepção térmica ao frio no ramo maxilar direito do que os controles $(p=0,002)$; no ramo maxilar esquerdo, os doentes com ND apresentaram 
limiares de percepção ao frio menores do que os controles $(p=0,001)$ (Figura 7).

A Figura 8 apresenta os limiares de percepção ao frio no ramo mandibular. Os doentes com ND apresentaram menores limiares do que os controles no lado direito $(p=0,002)$. Não houve diferenças entre os grupos no lado esquerdo $(p>0,05)$. 
Figura 7 - $\quad$ Avaliação sensitiva quantitativa térmica (frio): comparação entre os diagnósticos para o ramo maxilar $(\mathrm{N}=459)$
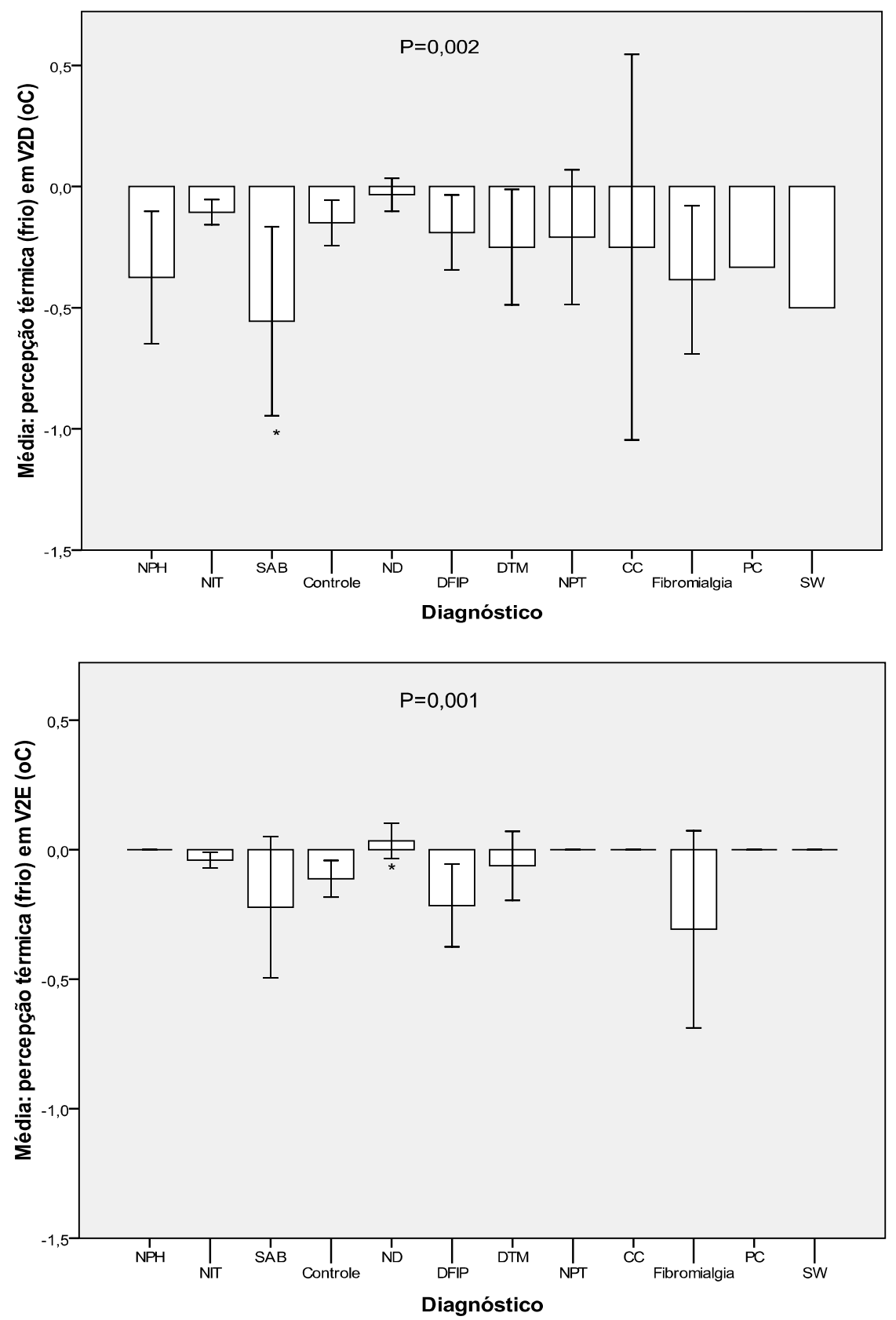

(*) Teste ANOVA 1 fator, PostHoc: teste de Tukey. As barras correspondem ao intervalo de confiança $95 \%$

${ }^{* *}$ NIT: Neuralgia Idiopática do Trigêmeo; DTM: Disfunção Temporomandibular; SAB: Síndrome da Ardência Bucal; DFIP: Dor Facial Idiopática Persistente; ND: Neuropatia diabética; NPH: Neuralgia Pós-herpética; NPT: Neuropatia Póstraumática; CC: Cefaléia Cervicogênica; PF: Paralisia facial; SW: Síndrome de Wallemberg

$\left({ }^{\star \star *}\right) \quad$ V2D: ramo maxilar direito; V2E: ramo maxilar esquerdo 
Figura 8 - $\quad$ Avaliação sensitiva quantitativa térmica (frio): comparação entre os diagnósticos para o ramo mandibular $(\mathrm{N}=459)$
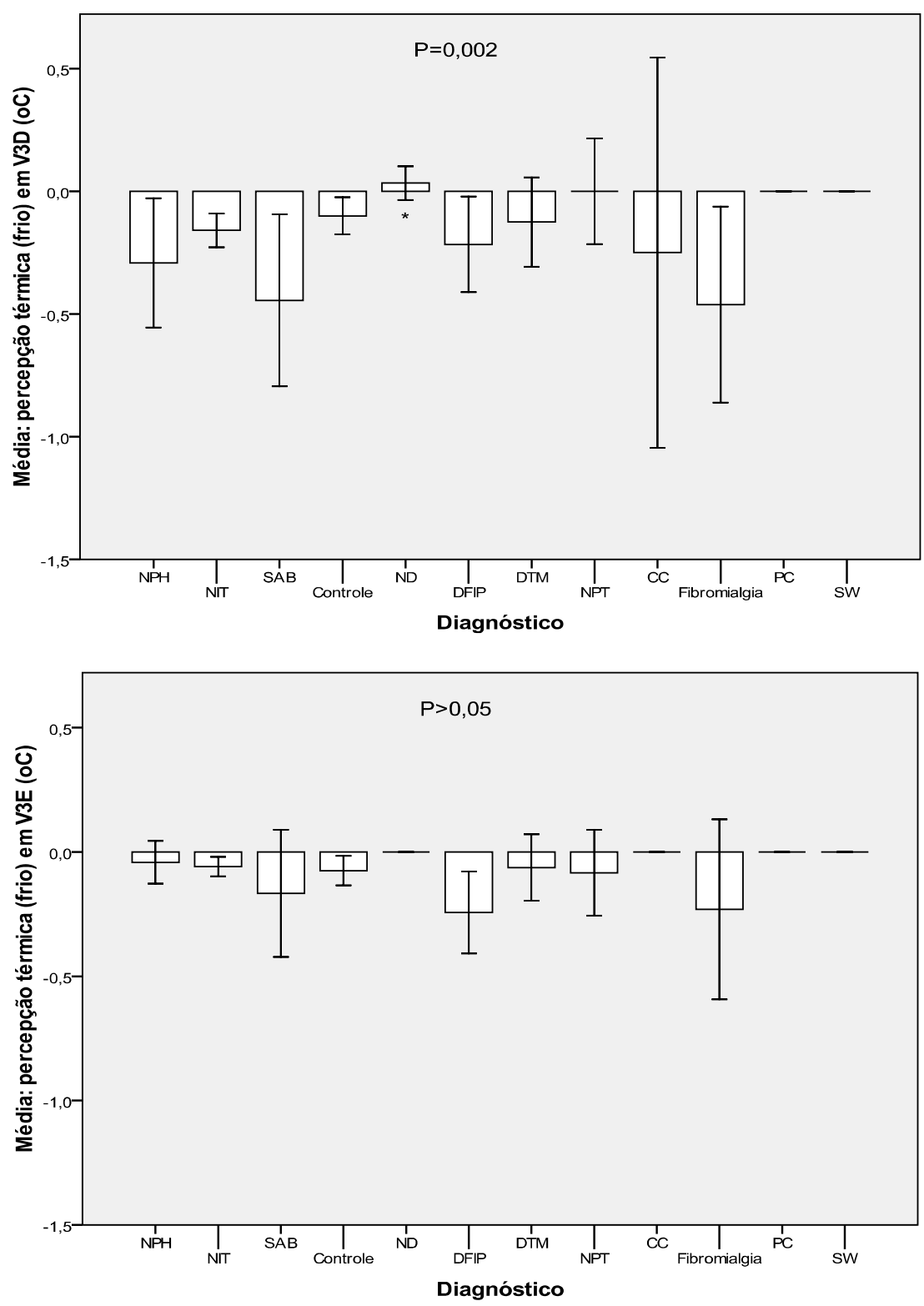

(*) Teste ANOVA 1 fator, PostHoc: teste de Tukey. As barras correspondem ao intervalo de confiança $95 \%$

${ }^{* *}$ NIT: Neuralgia Idiopática do Trigêmeo; DTM: Disfunção Temporomandibular; SAB: Síndrome da Ardência Bucal; DFIP: Dor Facial Idiopática Persistente; ND: Neuropatia diabética; NPH: Neuralgia Pós-herpética; NPT: Neuropatia Póstraumática; CC: Cefaléia Cervicogênica; PF: Paralisia facial; SW: Síndrome de Wallemberg.

$\left.{ }^{* * *}\right) \quad$ V3D: ramo mandibular direito; V3E: ramo mandibular esquerdo.

A Figura 9 apresenta as diferenças de percepção térmica ao calor nos ramos oftálmicos direito e esquerdo. No lado afetado/direto, os doentes com SAB e NPH apresentaram maiores limiares do que os doentes com 
DFIP e ND; os doentes com NPH também diferiram de NIT $(p<0,001)$. No lado oposto/esquerdo, os doentes com NIT e ND diferiram dos controles $(p<0,001)$

No ramo maxilar afetado/direito, a percepção térmica ao calor apresentou menor limiar para os doentes com ND $(p=0,005)$. Não houve diferenças entre os grupos no lado esquerdo $(p>0,05)$ (Figura 10).

As mesmas diferenças de percepção térmica ao calor dos doentes com ND foram observadas nos ramos mandibulares $(p=0,039$ a $p=0,003$ respectivamente direito e esquerdo) (Figura 11). 
Figura 9 - $\quad$ Avaliação sensitiva quantitativa térmica (calor): comparação entre os diagnósticos para o ramo oftálmico $(\mathrm{N}=459)$
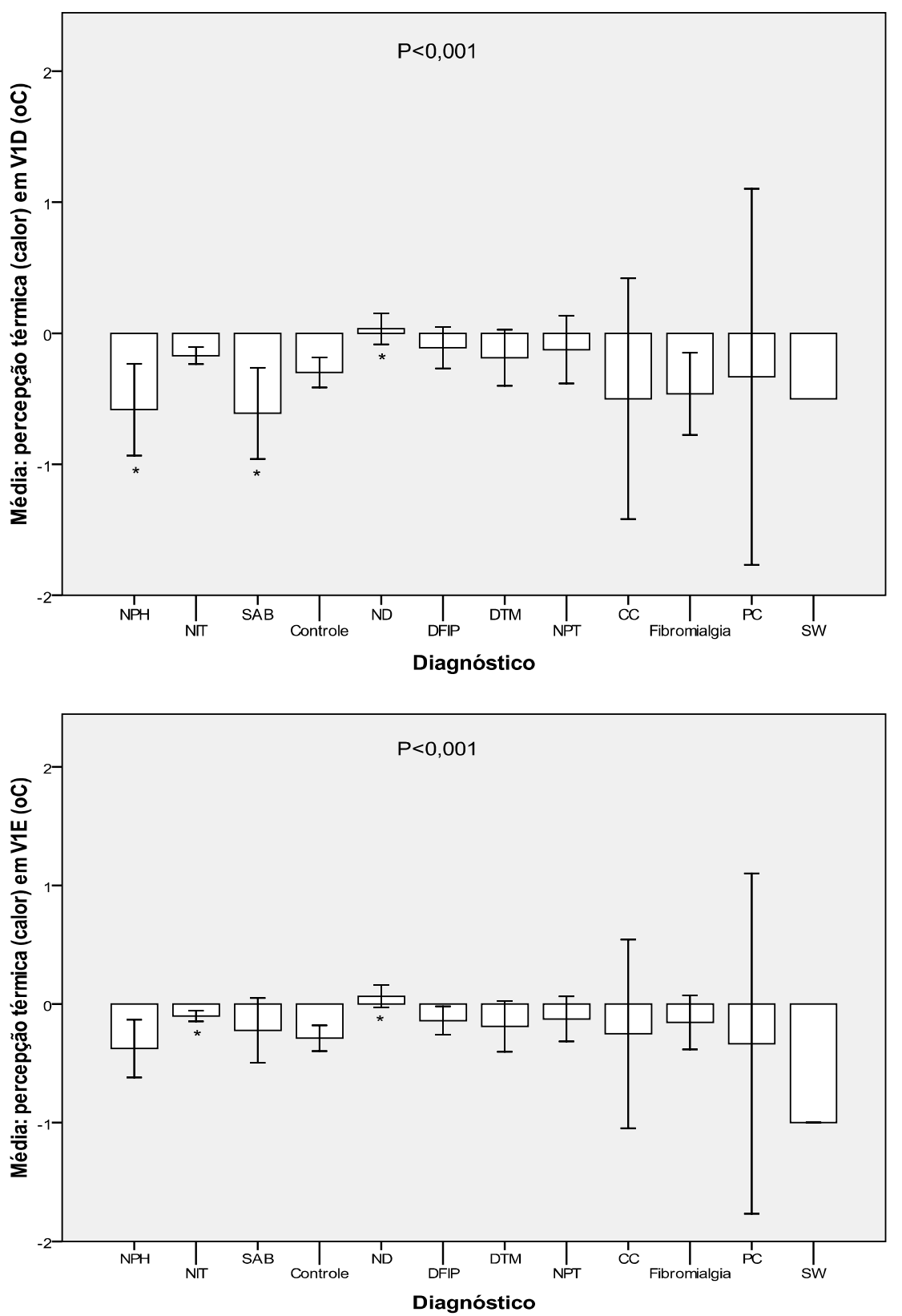

(*) Teste ANOVA 1 fator, PostHoc: teste de Tukey. As barras correspondem ao intervalo de confiança $95 \%$

${ }^{* *}$ NIT: Neuralgia Idiopática do Trigêmeo; DTM: Disfunção Temporomandibular; SAB: Síndrome da Ardência Bucal; DFIP: Dor Facial Idiopática Persistente; ND: Neuropatia diabética; NPH: Neuralgia Pós-herpética; NPT: Neuropatia Póstraumática; CC: Cefaléia Cervicogênica; PF: Paralisia facial; SW: Síndrome de Wallemberg.

${ }^{* * *}$ V1D: ramo oftálmico direito; V1E: ramo oftálmico esquerdo. 
Figura 10 - $\quad$ Avaliação sensitiva quantitativa térmica (calor): comparação entre os diagnósticos para o ramo maxilar $(\mathrm{N}=459)$
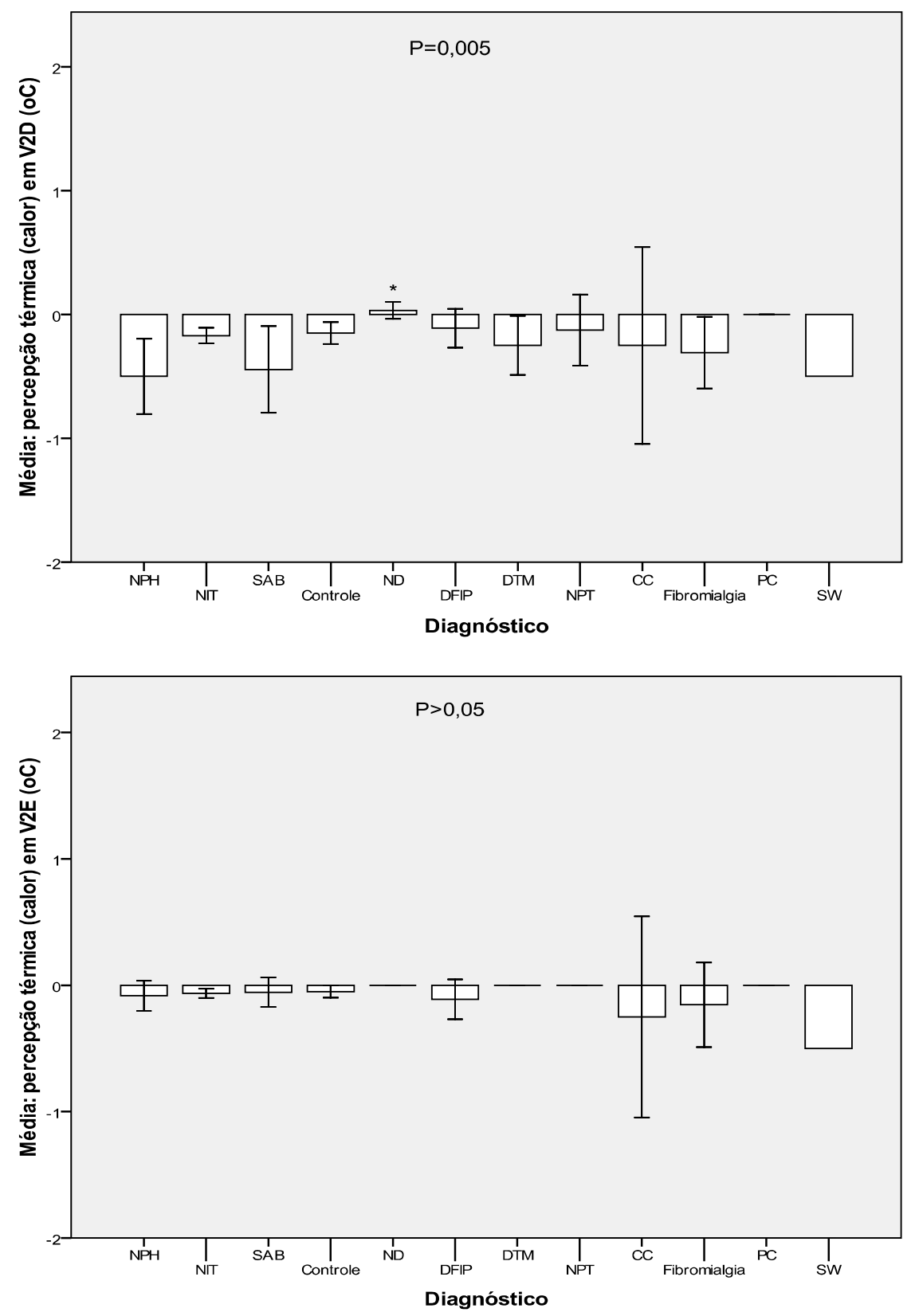

(*) Teste ANOVA 1 fator, PostHoc: teste de Tukey. As barras correspondem ao intervalo de confiança $95 \%$

${ }^{* *}$ NIT: Neuralgia Idiopática do Trigêmeo; DTM: Disfunção Temporomandibular; SAB: Síndrome da Ardência Bucal; DFIP: Dor Facial Idiopática Persistente; ND: Neuropatia diabética; NPH: Neuralgia Pós-herpética; NPT: Neuropatia Póstraumática; CC: Cefaléia Cervicogênica; PF: Paralisia facial; SW: Síndrome de Wallemberg.

$\left.{ }^{* * *}\right) \quad$ V2D: ramo maxilar direito; V2E: ramo maxilar esquerdo. 
Figura 11 - Avaliação sensitiva quantitativa térmica (calor): comparação entre os diagnósticos para o ramo mandibular $(\mathrm{N}=459)$
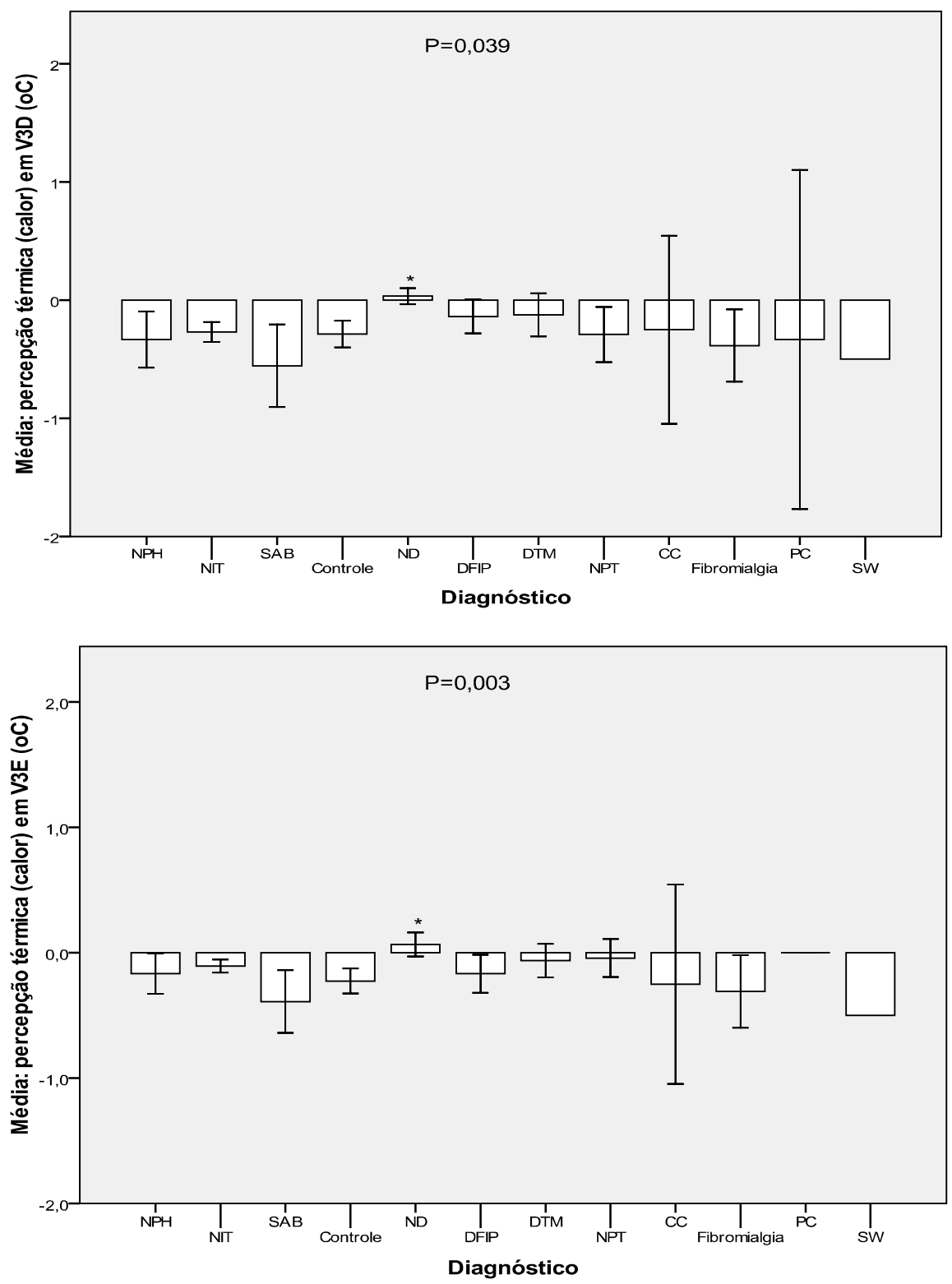

(*) Teste ANOVA 1 fator, PostHoc: teste de Tukey. As barras correspondem ao intervalo de confiança $95 \%$

$\left({ }^{* *}\right) \quad$ NIT: Neuralgia Idiopática do Trigêmeo; DTM: Disfunção Temporomandibular; SAB: Síndrome da Ardência Bucal; DFIP: Dor Facial Idiopática Persistente; ND: Neuropatia diabética; NPH: Neuralgia Pós-herpética; NPT: Neuropatia Póstraumática; CC: Cefaléia Cervicogênica; PF: Paralisia facial; SW: Síndrome de Wallemberg.

$\left.{ }^{(* *}\right) \quad$ V2D: ramo mandibular direito; V3E: ramo mandibular esquerdo.

Os doentes com NPH apresentaram os maiores limiares mecânicos tácteis no ramo oftálmico afetado/direito, seguidos dos doentes 
com SAB $(p<0,001)$. Não houve diferenças no lado esquerdo $(p>0,05)$ (Figura 12).

No ramo maxilar afetado/direito, os doentes com NIT, DFIP e DTM apresentaram maiores limiares do que doentes com ND $(p=0,023)$. Não houve diferenças para o lado afetado/direito (Figura 13).

Os doentes com NIT apresentaram maiores limiares mecânicos tácteis no ramo mandibular esquerdo quando comparados aos controles $(p=0,009)$. Não houve diferenças no lado direito (Figura 14). 
Figura 12 - $\quad$ Avaliação sensitiva quantitativa mecânica táctil: comparação entre os diagnósticos para o ramo oftálmico $(\mathrm{N}=459)$
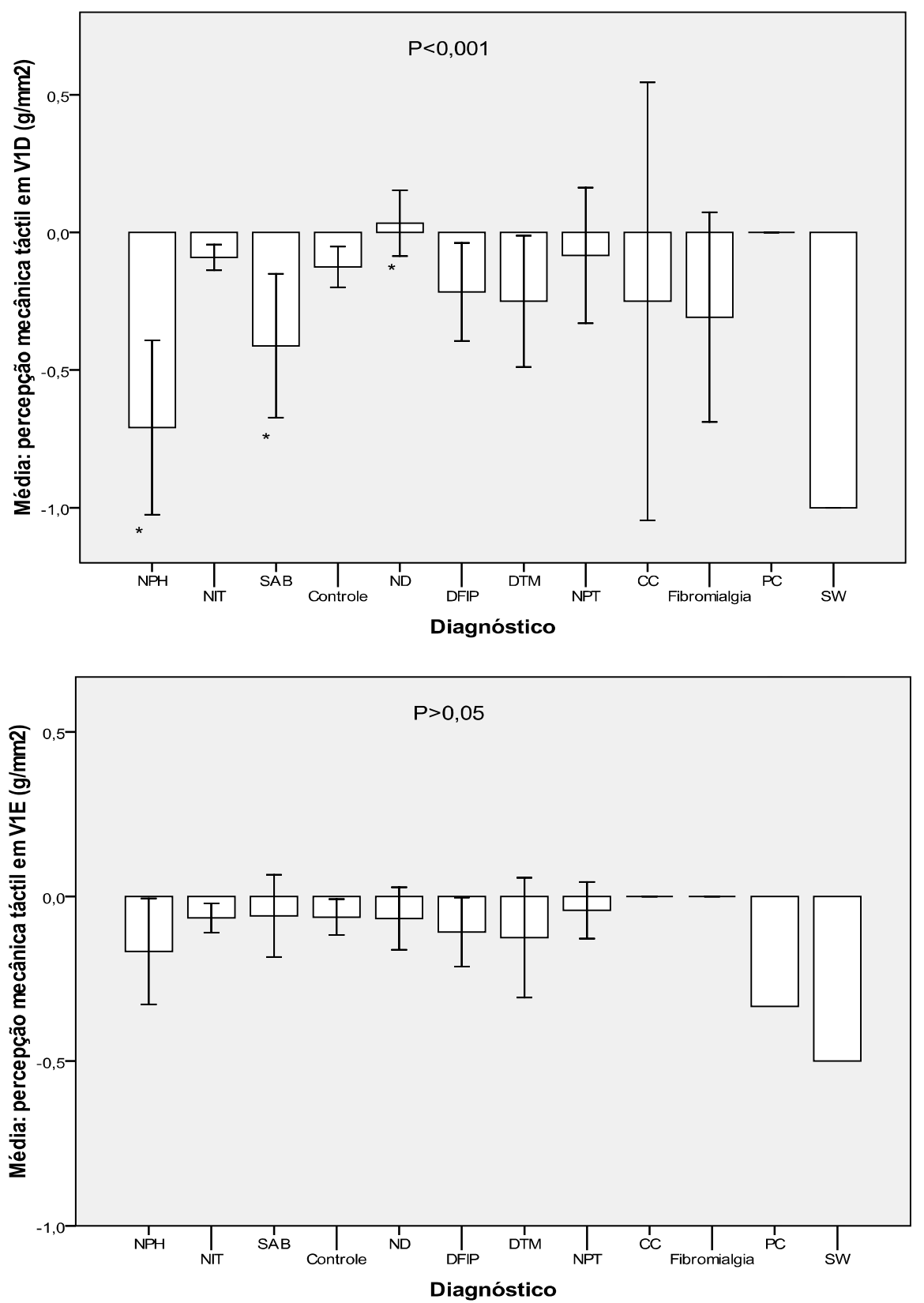

(*) Teste ANOVA 1 fator, PostHoc: teste de Tukey. As barras correspondem ao intervalo de confiança $95 \%$

$\left.{ }^{* *}\right) \quad$ NIT: Neuralgia Idiopática do Trigêmeo; DTM: Disfunção Temporomandibular; SAB: Síndrome da Ardência Bucal; DFIP: Dor Facial Idiopática Persistente; ND: Neuropatia diabética; NPH: Neuralgia Pós-herpética; NPT: Neuropatia Póstraumática; CC: Cefaléia Cervicogênica; PF: Paralisia facial; SW: Síndrome de Wallemberg.

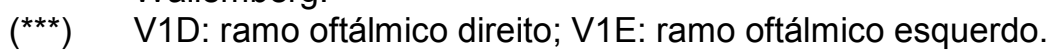


Figura 13 - $\quad$ Avaliação sensitiva quantitativa mecânica táctil: comparação entre os diagnósticos para o ramo maxilar $(\mathrm{N}=459)$
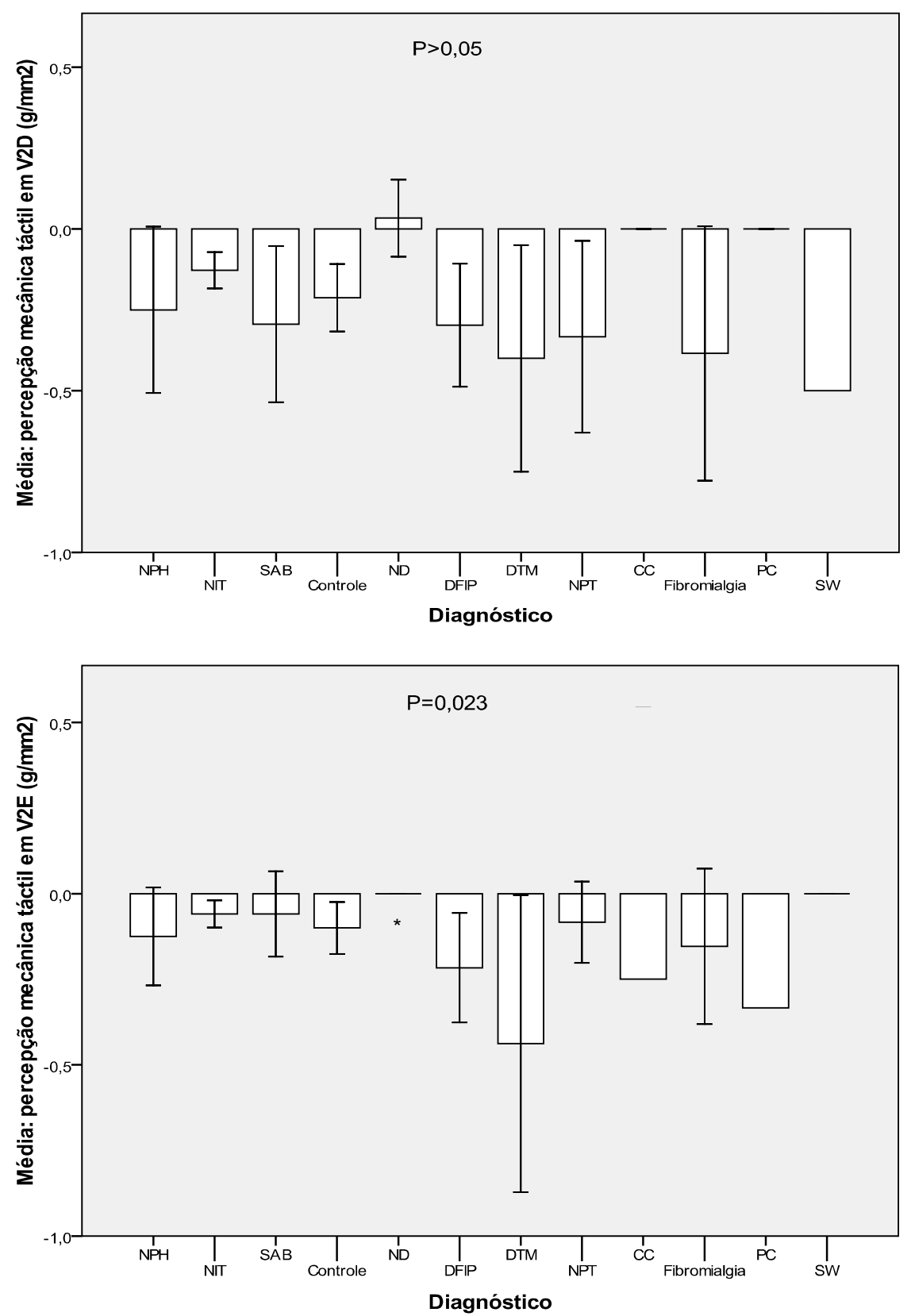

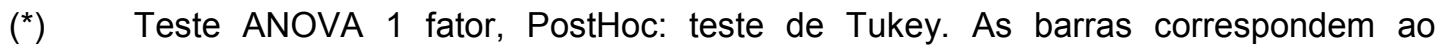
intervalo de confiança $95 \%$

$\left({ }^{* *}\right)$ NIT: Neuralgia Idiopática do Trigêmeo; DTM: Disfunção Temporomandibular; SAB: Síndrome da Ardência Bucal; DFIP: Dor Facial Idiopática Persistente; ND: Neuropatia diabética; NPH: Neuralgia Pós-herpética; NPT: Neuropatia Póstraumática; CC: Cefaléia Cervicogênica; PF: Paralisia facial; SW: Síndrome de Wallemberg.

${ }^{* * *}$ V2D: ramo maxilar direito; V2E: ramo maxilar esquerdo. 
Figura 14 - Avaliação sensitiva quantitativa mecânica táctil: comparação entre os diagnósticos para o ramo mandibular $(\mathrm{N}=459)$
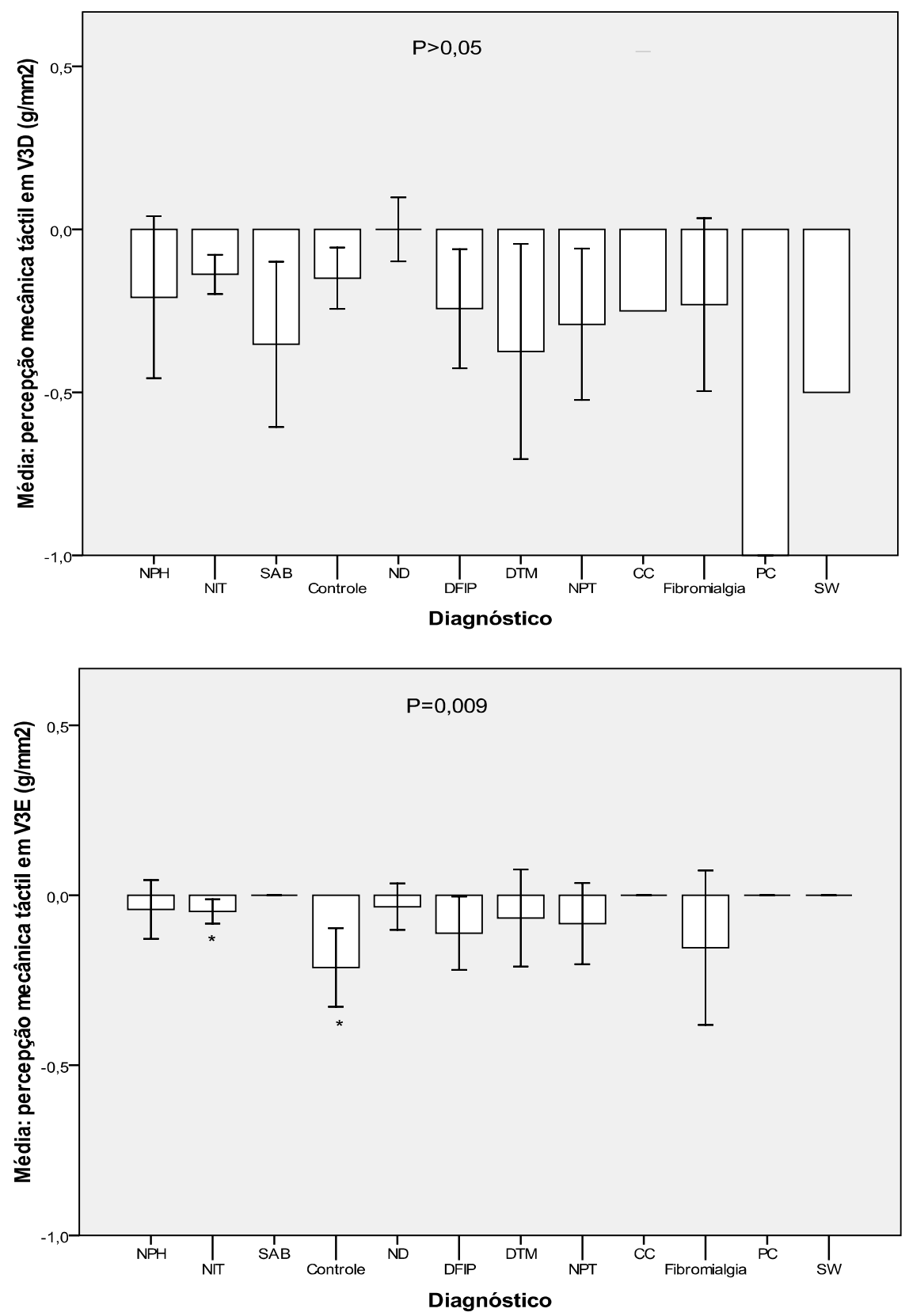

$\left(^{*}\right)$ Teste ANOVA 1 fator, PostHoc: teste de Tukey. As barras correspondem ao intervalo de confiança $95 \%$

$\left({ }^{* *}\right) \quad$ NIT: Neuralgia Idiopática do Trigêmeo; DTM: Disfunção Temporomandibular; SAB: Síndrome da Ardência Bucal; DFIP: Dor Facial Idiopática Persistente; ND: Neuropatia diabética; NPH: Neuralgia Pós-herpética; NPT: Neuropatia Póstraumática; CC: Cefaléia Cervicogênica; PF: Paralisia facial; SW: Síndrome de Wallemberg.

$\left({ }^{* * *}\right) \quad$ V3D: ramo mandibular direito; V3E: ramo mandibular esquerdo. 
Houve diferença no grupo de NPH quando comparado aos doentes com NIT, SAB, ND, DFIP, NPT e aos controles com relação à percepção mecânica dolorosa no ramo oftálmico afetado/direito $(p<0,001)$ (Figura 15). NPH também diferiu dos doentes com NIT, SAB e ND no ramo oftálmico esquerdo $(p<0,001)$.

Os doentes com ND apresentaram menores limiares de percepção mecânica dolorosa no ramo maxilar direito do que os controles, SAB e NPT $(p=0,004)$. Houve diferença entre os doentes com ND e NIT com relação aos controles na percepção mecânica dolorosa no ramo maxilar esquerdo $(p=0,002)$ (Figura 16).

A Figura 17 apresenta os limiares de percepção mecânica dolorosa no ramo mandibular. Doentes com ND e NIT apresentaram limiares menores do que os controles no lado esquerdo $(p=0,026)$. Não houve diferenças no lado direito. 
Figura 15 - Avaliação sensitiva quantitativa mecânica dolorosa: comparação entre os diagnósticos para o ramo oftálmico $(\mathrm{N}=459)$
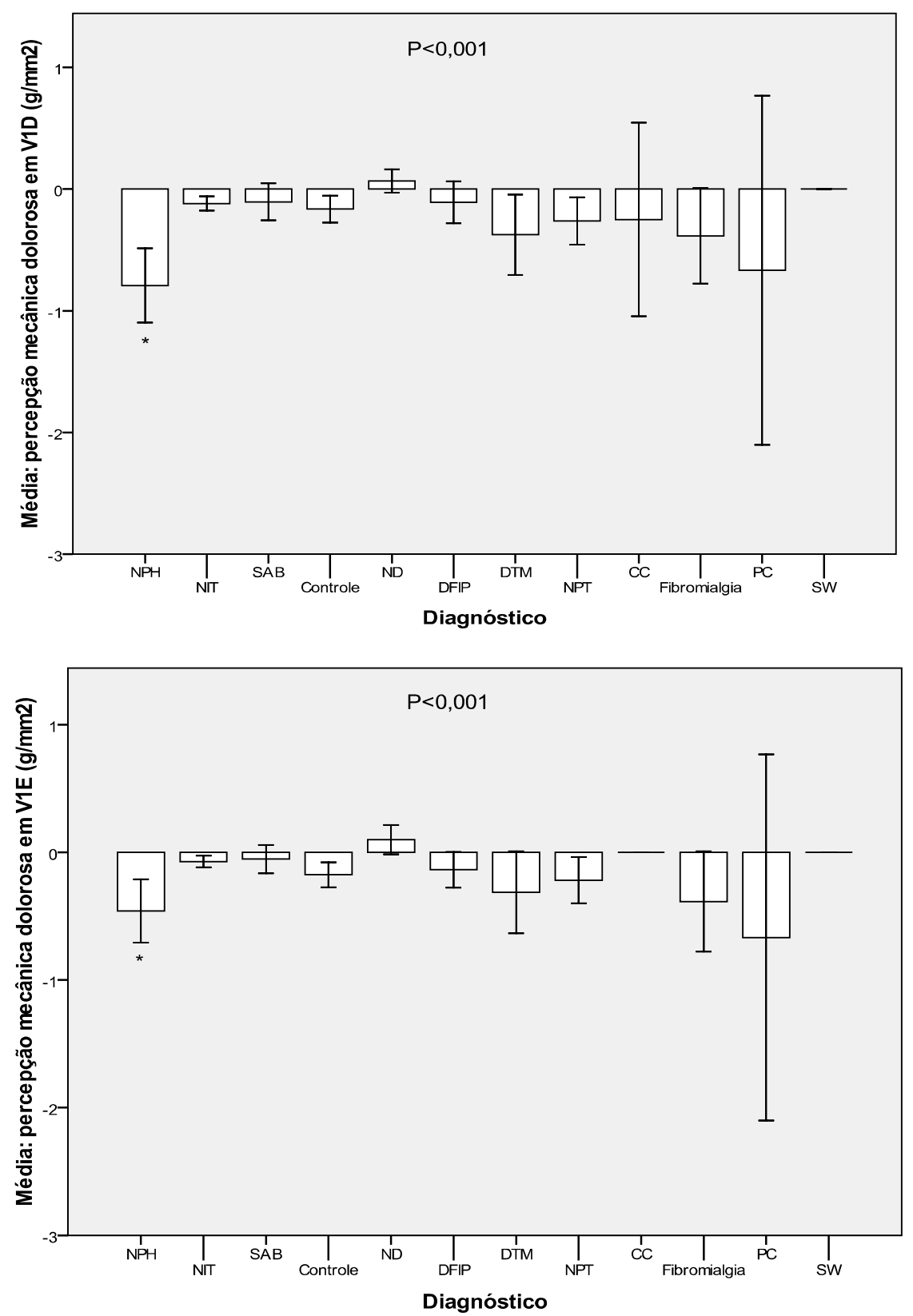

(*) Teste ANOVA 1 fator, PostHoc: teste de Tukey. As barras correspondem ao intervalo de confiança $95 \%$

${ }^{* *}$ NIT: Neuralgia Idiopática do Trigêmeo; DTM: Disfunção Temporomandibular; SAB: Síndrome da Ardência Bucal; DFIP: Dor Facial Idiopática Persistente; ND: Neuropatia diabética; NPH: Neuralgia Pós-herpética; NPT: Neuropatia Póstraumática; CC: Cefaléia Cervicogênica; PF: Paralisia facial; SW: Síndrome de Wallemberg.

$\left({ }^{* * *}\right) \quad$ V1D: ramo oftálmico direito; V1E: ramo oftálmico esquerdo. 
Figura 16 - Avaliação sensitiva quantitativa mecânica dolorosa: comparação entre os diagnósticos para o ramo maxilar $(\mathrm{N}=459)$
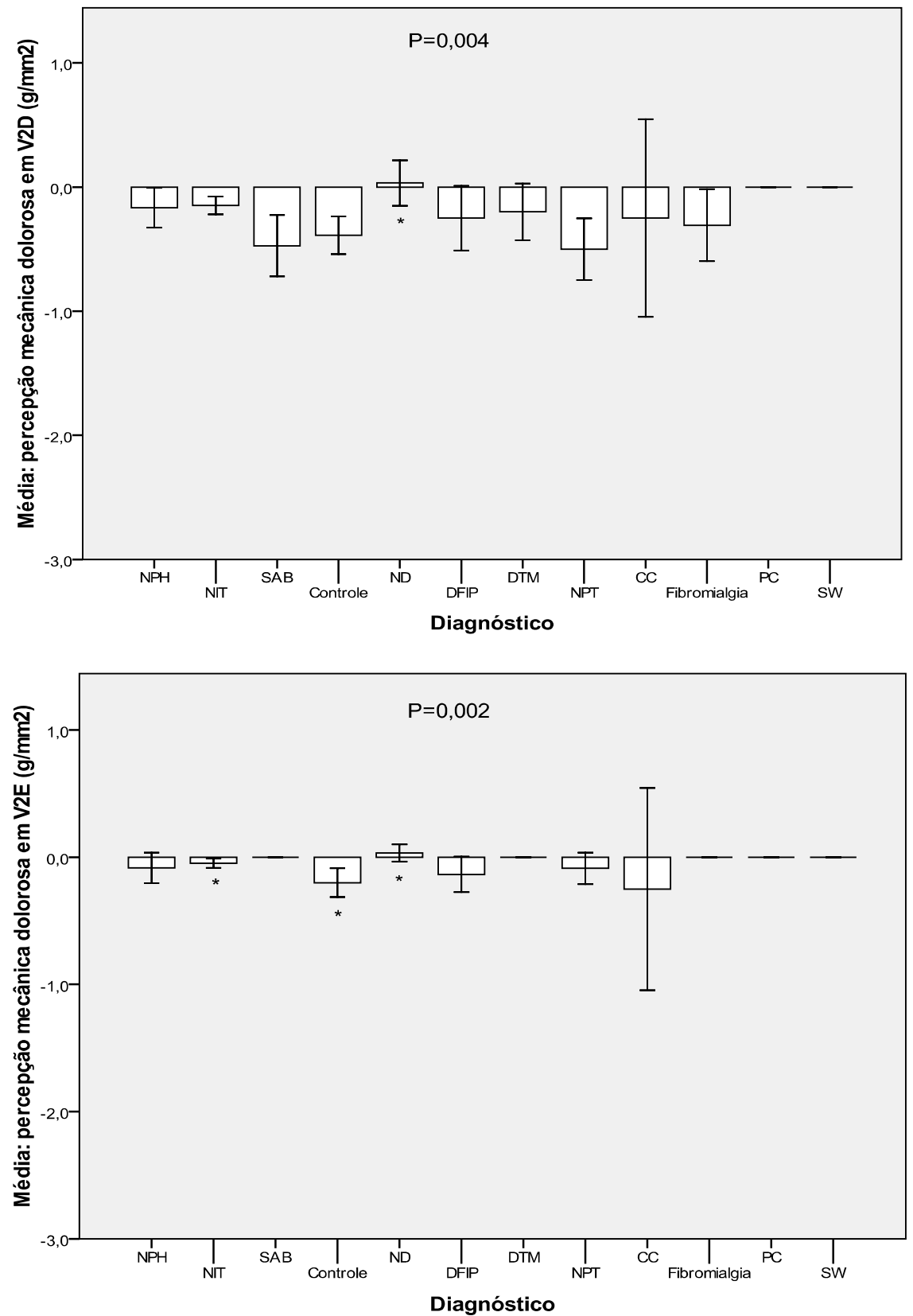

(*) Teste ANOVA 1 fator, PostHoc: teste de Tukey. As barras correspondem ao intervalo de confiança $95 \%$

$\left({ }^{* *}\right) \quad$ NIT: Neuralgia Idiopática do Trigêmeo; DTM: Disfunção Temporomandibular; SAB: Síndrome da Ardência Bucal; DFIP: Dor Facial Idiopática Persistente; ND: Neuropatia diabética; NPH: Neuralgia Pós-herpética; NPT: Neuropatia Póstraumática; CC: Cefaléia Cervicogênica; PF: Paralisia facial; SW: Síndrome de Wallemberg.

$\left.{ }^{* * *}\right) \quad$ V2D: ramo maxilar direito; V2E: ramo maxilar esquerdo. 
Figura 17 - Avaliação sensitiva quantitativa mecânica dolorosa: comparação entre os diagnósticos para o ramo mandibular $(\mathrm{N}=459)$
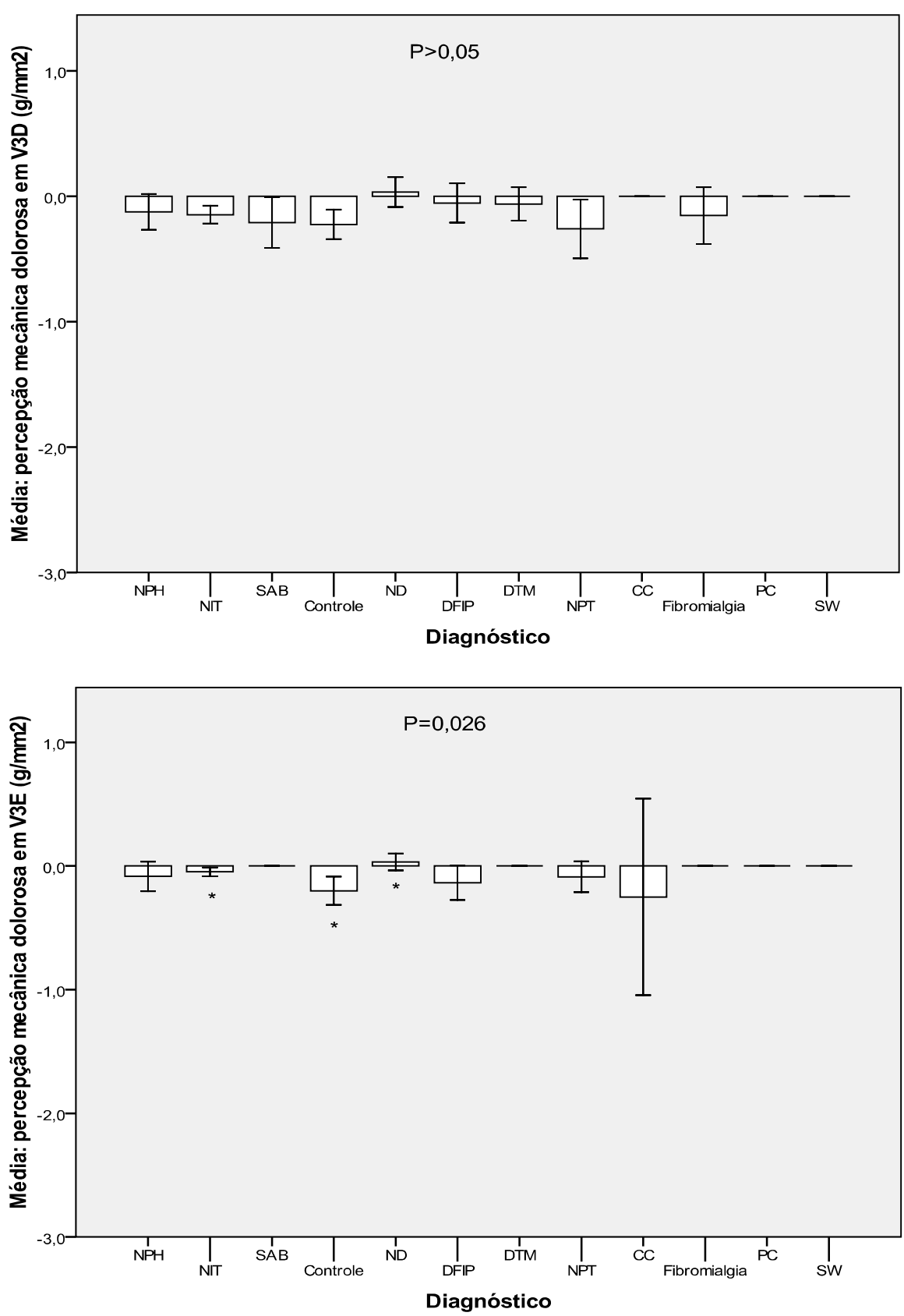

(*) Teste ANOVA 1 fator, PostHoc: teste de Tukey. As barras correspondem ao intervalo de confiança $95 \%$

$\left({ }^{* *}\right) \quad$ NIT: Neuralgia Idiopática do Trigêmeo; DTM: Disfunção Temporomandibular; SAB: Síndrome da Ardência Bucal; DFIP: Dor Facial Idiopática Persistente; ND: Neuropatia diabética; NPH: Neuralgia Pós-herpética; NPT: Neuropatia Póstraumática; CC: Cefaléia Cervicogênica; PF: Paralisia facial; SW: Síndrome de Wallemberg.

$\left(^{* * *}\right) \quad$ V3D: ramo mandibular direito; V3E: ramo mandibular esquerdo. 
A Figura 18 apresenta os valores de algiometria de superfície no ramo oftálmico. Os controles apresentaram limiares maiores do que $\mathrm{NPH}$, NIT, SAB, ND, DFIP, DTM e NPT no lado afetado/direito $(p<0,001)$. No lado esquerdo, não houve diferenças.

No ramo maxilar afetado/direito, houve maiores limiares de algiometria de superfície nos doentes com NIT quando comparados aos controles ( $p=0,001)$ (Figura 19). Não houve diferenças no lado esquerdo.

Os ramos mandibulares direito e esquerdo não apresentaram diferenças entre os grupos com relação à algiometria de superfície $(p>0,05)$ (Figura 20). 
Figura 18 - Avaliação sensitiva quantitativa dolorosa de superfície: comparação entre os diagnósticos para o ramo oftálmico $(\mathrm{N}=459)$
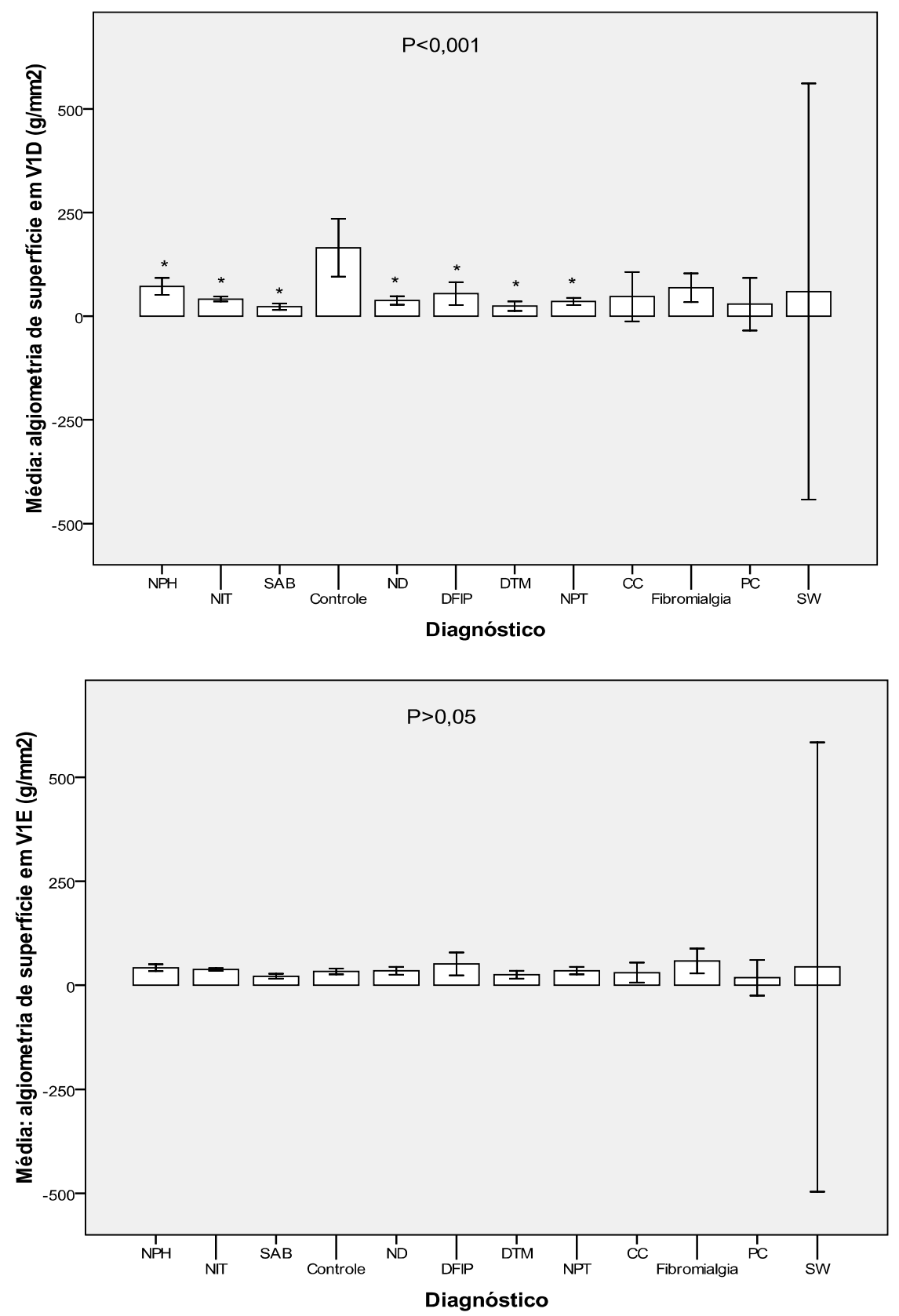

$\left(^{*}\right)$ Teste ANOVA 1 fator, PostHoc: teste de Tukey. As barras correspondem ao intervalo de confiança $95 \%$

${ }^{* *}$ NIT: Neuralgia Idiopática do Trigêmeo; DTM: Disfunção Temporomandibular; SAB: Síndrome da Ardência Bucal; DFIP: Dor Facial Idiopática Persistente; ND: Neuropatia diabética; NPH: Neuralgia Pós-herpética; NPT: Neuropatia Póstraumática; CC: Cefaléia Cervicogênica; PF: Paralisia facial; SW: Síndrome de Wallemberg

$\left(^{* * *}\right.$ V1D: ramo oftálmico direito; V1E: ramo oftálmico esquerdo. 
Figura 19 - Avaliação sensitiva quantitativa dolorosa de superfície: comparação entre os diagnósticos para o ramo maxilar $(\mathrm{N}=459)$
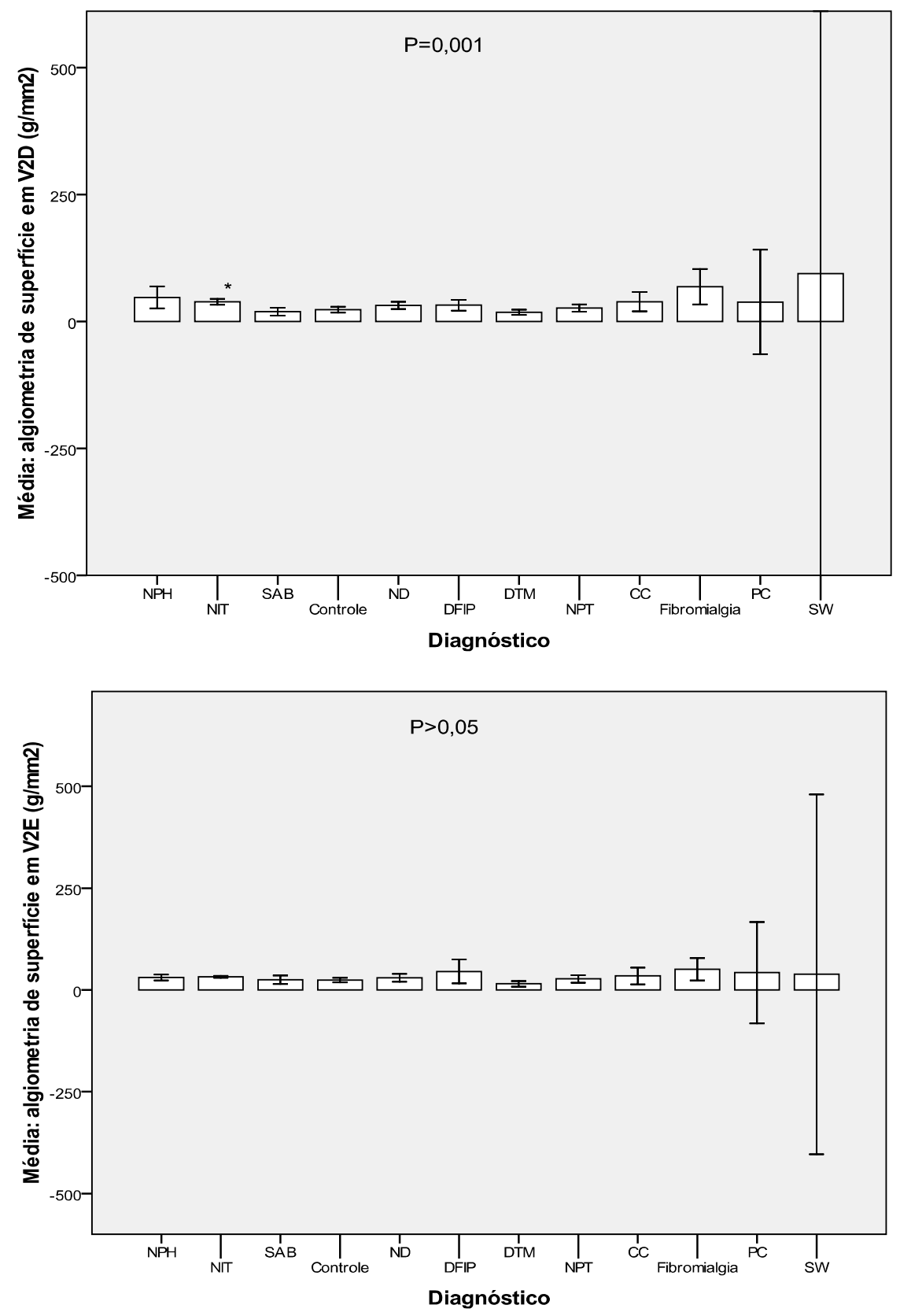

(*) Teste ANOVA 1 fator, PostHoc: teste de Tukey. As barras correspondem ao intervalo de confiança $95 \%$

${ }^{* *}$ NIT: Neuralgia Idiopática do Trigêmeo; DTM: Disfunção Temporomandibular; SAB: Síndrome da Ardência Bucal; DFIP: Dor Facial Idiopática Persistente; ND: Neuropatia diabética; NPH: Neuralgia Pós-herpética; NPT: Neuropatia Póstraumática; CC: Cefaléia Cervicogênica; PF: Paralisia facial; SW: Síndrome de Wallemberg.

$\left.{ }^{(* *}\right) \quad$ V2D: ramo maxilar direito; V2E: ramo maxilar esquerdo. 
Figura 20 - Avaliação sensitiva quantitativa dolorosa de superfície: comparação entre os diagnósticos para o ramo mandibular $(\mathrm{N}=459)$
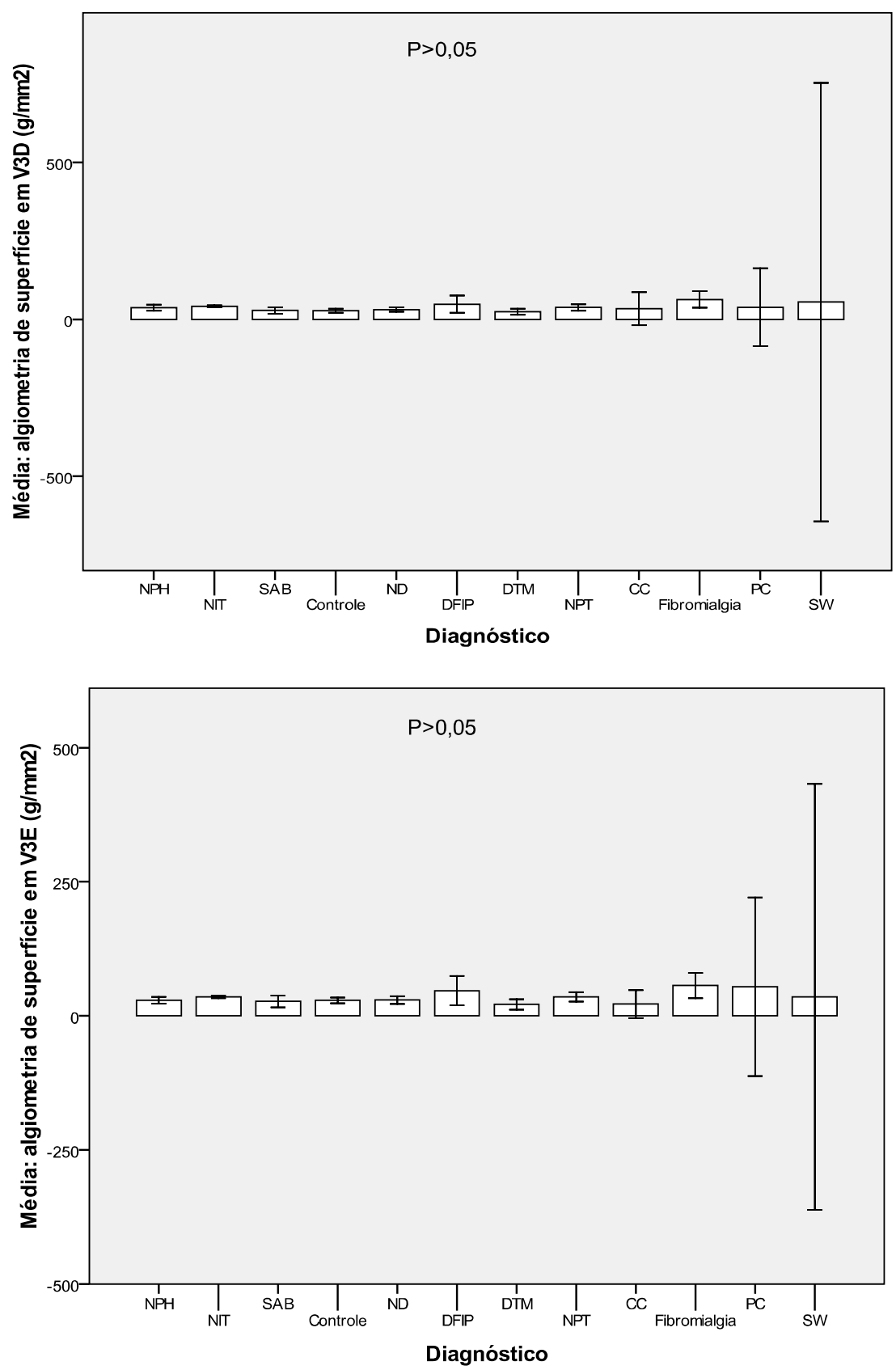

$\left({ }^{*}\right) \quad$ Teste ANOVA 1 fator. As barras correspondem ao intervalo de confiança $95 \%$

$\left({ }^{* *}\right)$ NIT: Neuralgia Idiopática do Trigêmeo; DTM: Disfunção Temporomandibular; SAB: Síndrome da Ardência Bucal; DFIP: Dor Facial Idiopática Persistente; ND: Neuropatia diabética; NPH: Neuralgia Pós-herpética; NPT: Neuropatia Póstraumática; CC: Cefaléia Cervicogênica; PF: Paralisia facial; SW: Síndrome de Wallemberg.

$\left({ }^{* * *}\right) \quad$ V1D: ramo mandibular direito; V3E: ramo mandibular esquerdo. 
Anormalidades do reflexo córneo-palpebral podem ser observadas na Tabela 7. Houve correlação positiva entre alteração do reflexo córneo-palpebral e duração da dor $(p<0,001)$. Quanto maior a intensidade de disestesia, maior a alteração do reflexo $(p=0,024)$.

Tabela 7 - Avaliação do reflexo córneo-palpebral nos lados direito/afetado e esquerdo/controle: comparação entre os diagnósticos $(\mathrm{N}=459)$

\begin{tabular}{lcc}
\hline & Reflexo direito (\%) & Reflexo esquerdo (\%) \\
\hline NIT & $26(13,6)$ & $12(6,3)$ \\
DTM & $04(26,7)$ & $03(20,0)$ \\
SAB & $4(21,1)$ & $5(26,3)$ \\
DFIP & - & $02(5,3)$ \\
ND & - & - \\
Fibromialgia & $02(15,4)$ & $03(23,1)$ \\
NPH & $13(54,2)$ & $09(37,5)$ \\
NPT & $02(8,3)$ & $02(8,3)$ \\
CC & - & - \\
PF & - & - \\
SW & $01(50,0)$ & $01(50,0)$ \\
Controle & $08(8,4)$ & $10(10,5)$ \\
TOTAL & $62(13,5)$ & $47(10,2)$ \\
p* & $<0,001^{* * *}$ & $<0,001 * * *$
\end{tabular}

\subsubsection{Sensibilidade gustativa e olfativa $(\mathrm{N}=123)$}

A sensibilidade gustativa e olfativa foi avaliada na amostra 2 . Hábito de fumar esteve presente em $10(8,1 \%)$ dos sujeitos; $13(10,6 \%)$ queixavam-se de paladar diminuído, 4 (3,3\%) de olfato diminuído, 8 (6,5\%) 
de paladar e olfato diminuídos, $2(1,6 \%)$ de gosto fantasma e $1(0,8 \%)$ de dor devido a temperatura dos alimentos. Não houve diferenças entre os grupos na avaliação gustativa individual para cada sabor (doce, salgado, azedo e amargo) (Figuras 21 e 22). Numericamente, os limiares dos doentes com fibromialgia foram maiores. Os doentes com NPH apresentaram valores superiores de limiar olfativo quando comparados com os outros grupos (Figura 23). Na avaliação das médias gerais gustativas, os doentes com fibromialgia diferiram de todos os outros grupos $(p<0,001)$. As médias dos limiares dos doentes com NPH, SAB, DFIP, DTM e NPT foram menores do que os controles (Figura 24). 
Figura 21 - Avaliação quantitativa gustativa (doce e salgado): comparação entre os diagnósticos $(\mathrm{N}=123)$
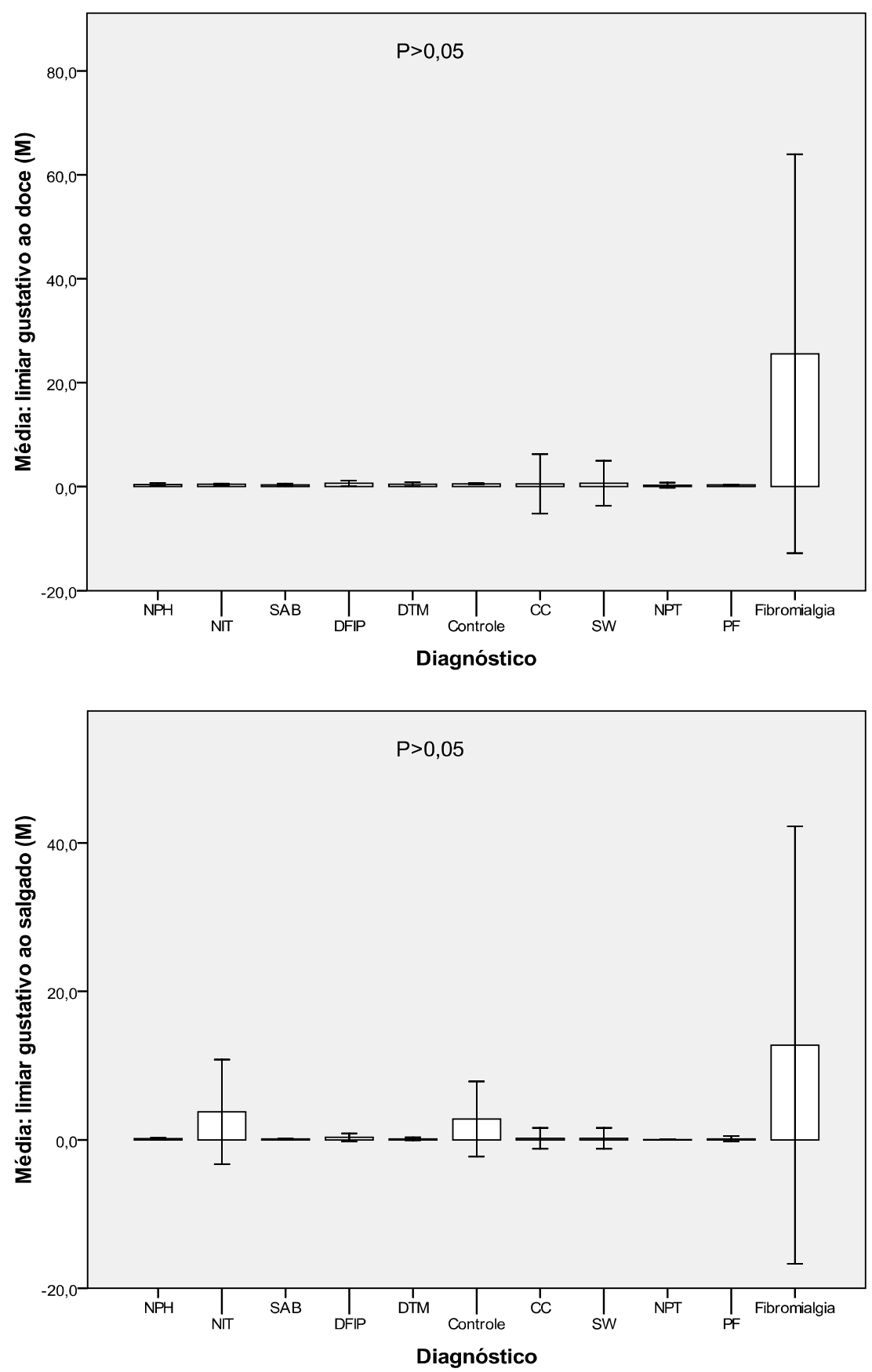

$\left(^{*}\right) \quad$ Teste ANOVA 1 fator. As barras correspondem ao intervalo de confiança 95\%

$\left({ }^{* *}\right) \quad$ NIT: Neuralgia Idiopática do Trigêmeo; DTM: Disfunção Temporomandibular; SAB: Síndrome da Ardência Bucal; DFIP: Dor Facial Idiopática Persistente; NPH: Neuralgia Pós-herpética; NPT: Neuropatia Pós-traumática; CC: Cefaléia Cervicogênica; PF: Paralisia facial; SW: Síndrome de Wallemberg. 
Figura 22 - Avaliação quantitativa gustativa (azedo e amargo): comparação entre os diagnósticos $(\mathrm{N}=123)$
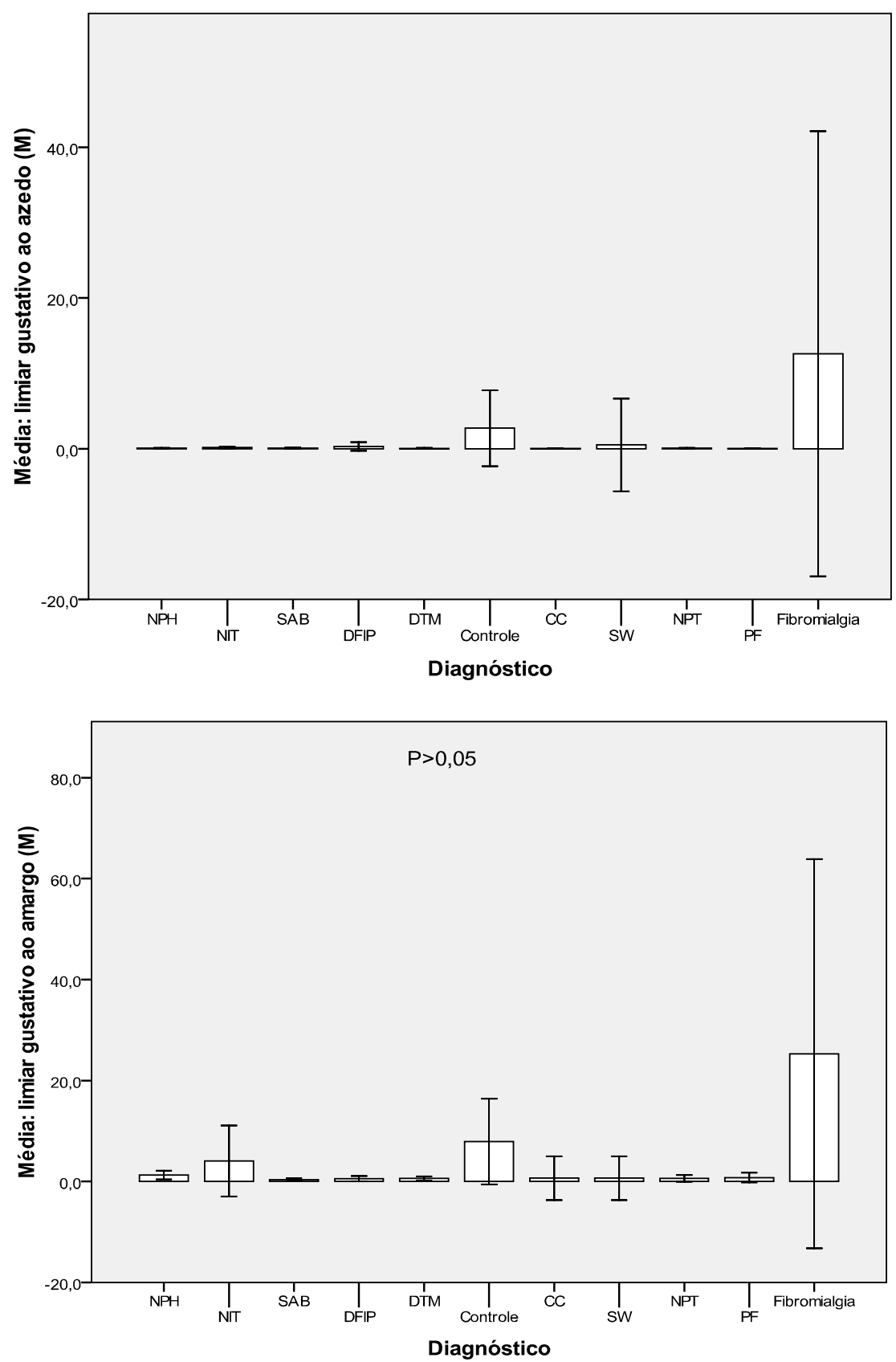

$\left.{ }^{*}\right) \quad$ Teste ANOVA 1 fator. As barras correspondem ao intervalo de confiança 95\%

$\left(^{* *}\right.$ NIT: Neuralgia Idiopática do Trigêmeo; DTM: Disfunção Temporomandibular; SAB: Síndrome da Ardência Bucal; DFIP: Dor Facial Idiopática Persistente; NPH: Neuralgia Pós-herpética; NPT: Neuropatia Pós-traumática; CC: Cefaléia Cervicogênica; PF: Paralisia facial; SW: Síndrome de Wallemberg. 
Figura 23 - Avaliação quantitativa olfativa: comparação entre os diagnósticos $(\mathrm{N}=123)$

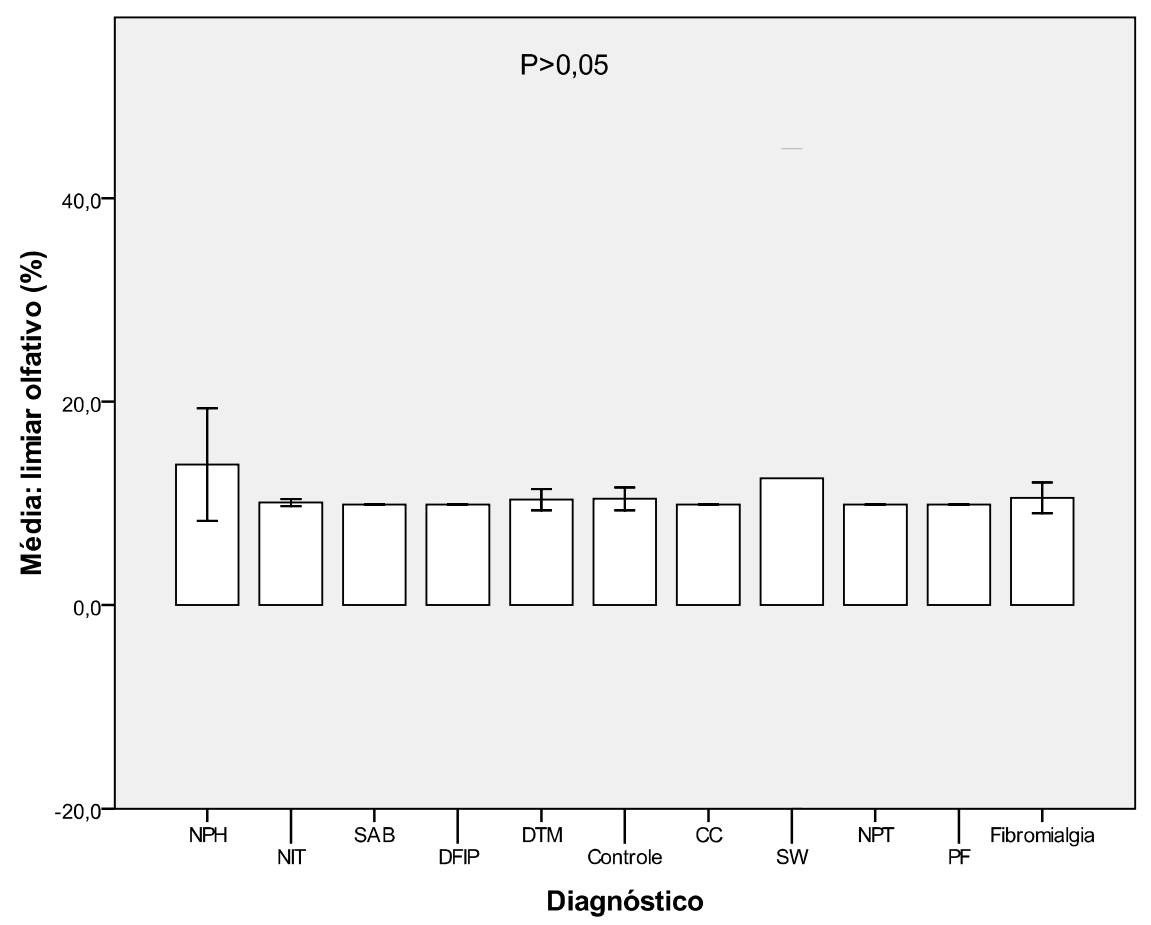

$\left(^{*}\right) \quad$ Teste ANOVA 1 fator. As barras correspondem ao intervalo de confiança $95 \%$

$\left({ }^{* *}\right)$ NIT: Neuralgia Idiopática do Trigêmeo; DTM: Disfunção Temporomandibular; SAB: Síndrome da Ardência Bucal; DFIP: Dor Facial Idiopática Persistente; NPH: Neuralgia Pós-herpética; NPT: Neuropatia Pós-traumática; CC: Cefaléia Cervicogênica; PF: Paralisia facial; SW: Síndrome de Wallemberg. 
Figura 24 - Avaliação quantitativa gustativa: comparação entre as médias dos limiares gustativos (doce, salgado, azedo e amargo) entre os diagnósticos $(\mathrm{N}=123)$

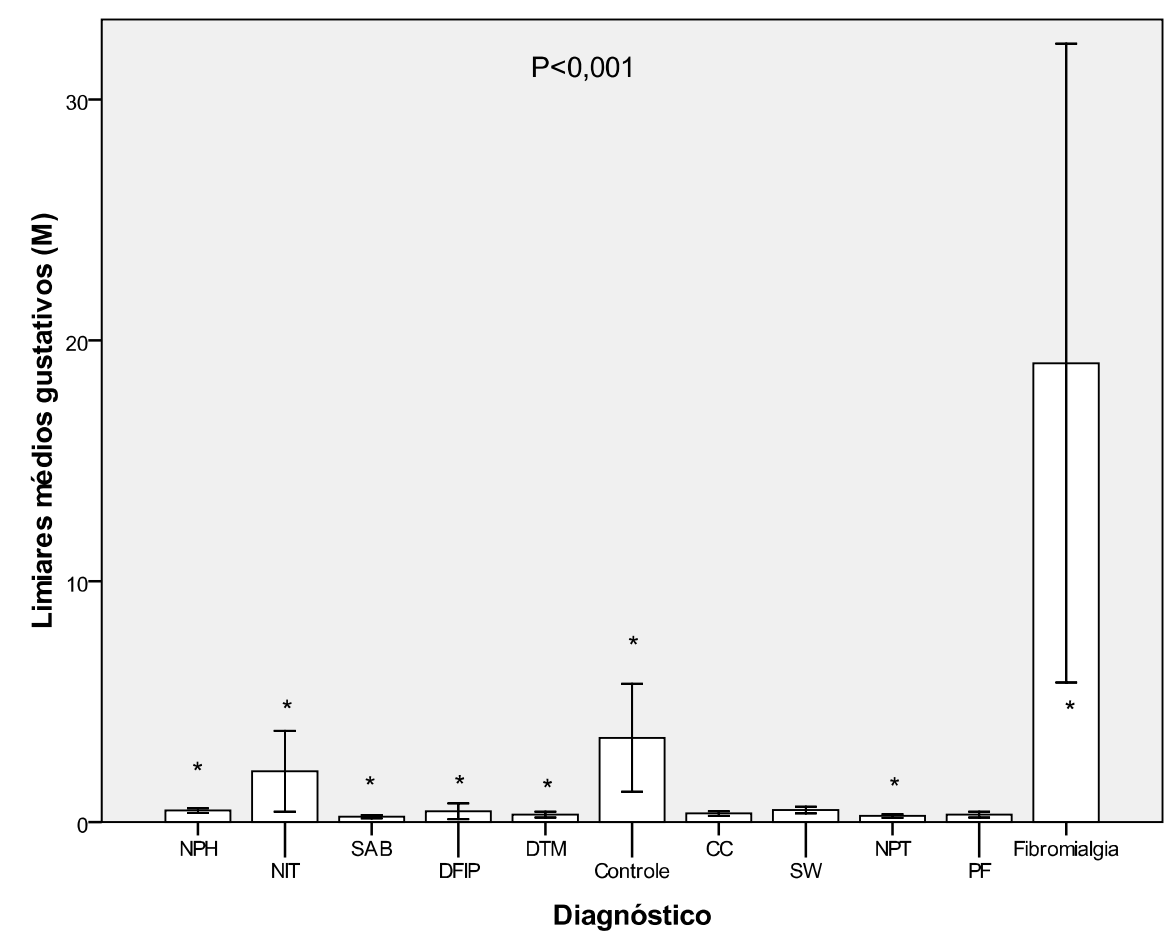

(*) Teste ANOVA 1 fator; teste postHoc Tukey. As barras correspondem ao intervalo de confiança $95 \%$

${ }^{* *}$ NIT: Neuralgia Idiopática do Trigêmeo; DTM: Disfunção Temporomandibular; SAB: Síndrome da Ardência Bucal; DFIP: Dor Facial Idiopática Persistente; NPH: Neuralgia Pós-herpética; NPT: Neuropatia Pós-traumática; CC: Cefaléia Cervicogênica; PF: Paralisia facial; SW: Síndrome de Wallemberg.

\subsubsection{Sensibilidade somestésica trigeminal em doentes com dor orofacial comparados a controles: limiares sensitivos $(\mathrm{N}=123)$}

As médias dos limiares quantitativos de sensibilidade, coletados na amostra 2 tanto em pontos faciais quanto nas mãos e pernas, foram analisados de maneira comparativa de acordo com os diagnósticos e podem ser observados nas figuras 25 a 31 . 
Os limiares térmicos ao frio foram maiores no grupo de doentes com NPH comparados aos controles $(p=0,003)$ (Figura 25). Não houve diferenças estatísticas entre os grupos nas médias de limiares térmicos ao calor (Figura 26), assim como nas médias de limiares mecânicos tácteis (Figura 27) e vibratórios (Figura 28).

Figura 25 - Avaliação sensitiva quantitativa térmica (frio): valores médios e comparação entre os diagnósticos $(\mathrm{N}=123)$

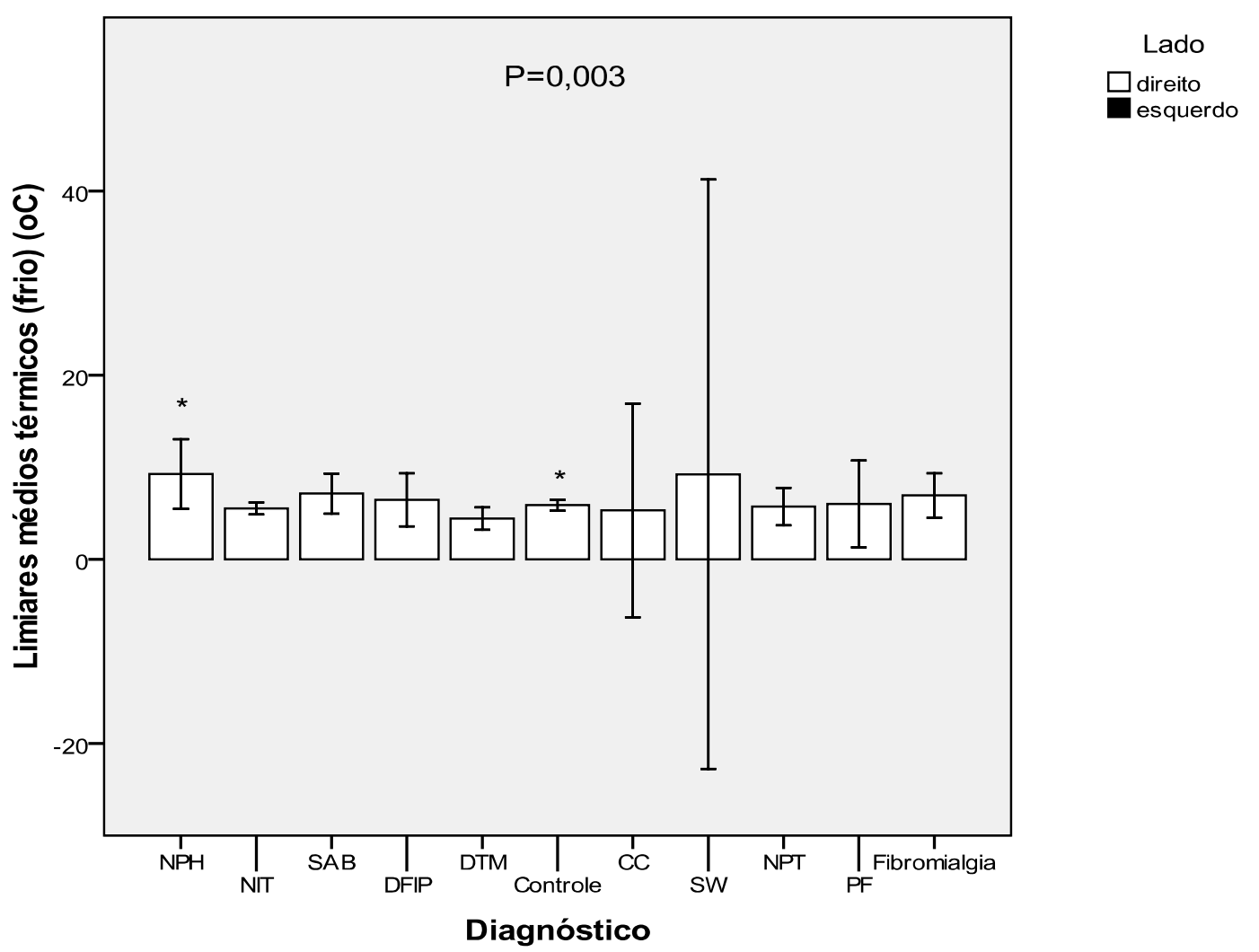

$\left(^{*}\right)$ Teste ANOVA 1 fator, PostHoc: teste de Tukey. As barras correspondem ao intervalo de confiança 95\%.

$\left.{ }^{(*}\right)$ NIT: Neuralgia Idiopática do Trigêmeo; DTM: Disfunção Temporomandibular; SAB: Síndrome da Ardência Bucal; DFIP: Dor Facial Idiopática Persistente; NPH: Neuralgia Pós-herpética; NPT: Neuropatia Pós-traumática; CC: Cefaléia Cervicogênica; PF: Paralisia facial; SW: Síndrome de Wallemberg. 
Figura 26 - Avaliação sensitiva quantitativa térmica (calor): valores médios e comparação entre os diagnósticos $(\mathrm{N}=123)$

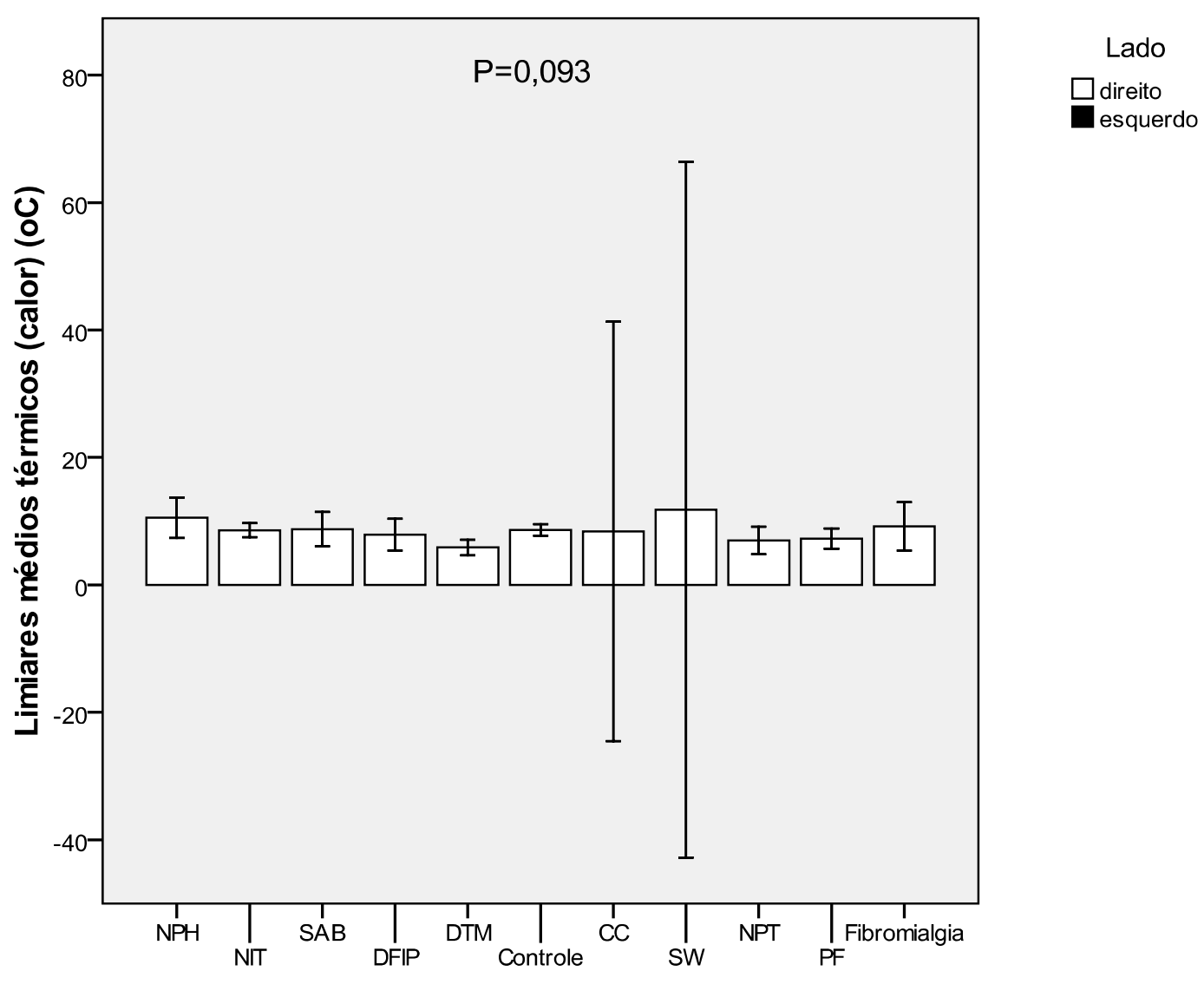

Diagnóstico

$\left(^{*}\right) \quad$ Teste ANOVA 1 fator. As barras correspondem ao intervalo de confiança 95\%.

$\left({ }^{* *}\right) \quad$ NIT: Neuralgia Idiopática do Trigêmeo; DTM: Disfunção Temporomandibular; SAB: Síndrome da Ardência Bucal; DFIP: Dor Facial Idiopática Persistente; NPH: Neuralgia Pós-herpética; NPT: Neuropatia Pós-traumática; CC: Cefaléia Cervicogênica; PF: Paralisia facial; SW: Síndrome de Wallemberg. 
Figura 27 - Avaliação sensitiva quantitativa mecânica táctil: valores médios e comparação entre os diagnósticos $(\mathrm{N}=123)$

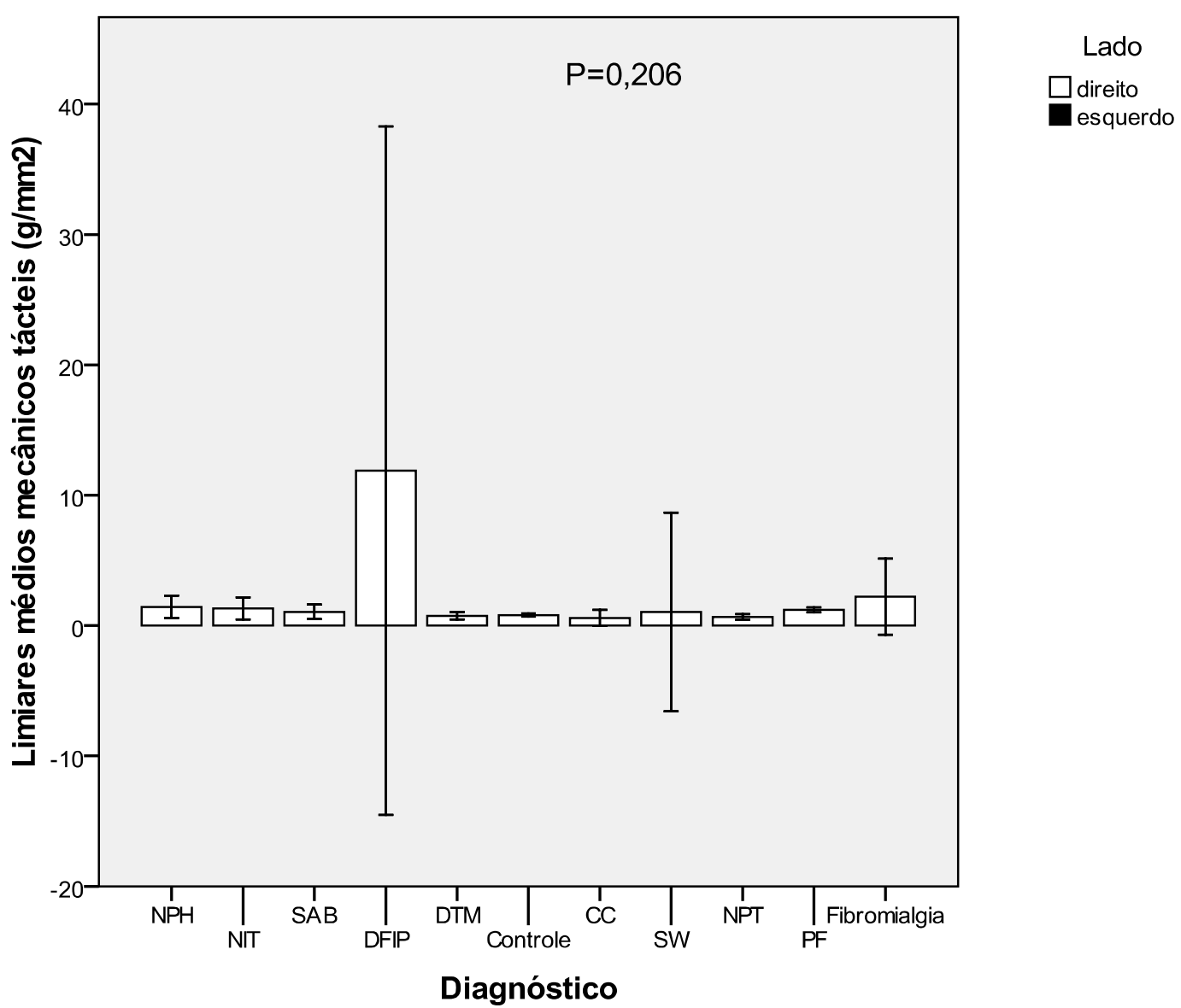

$\left.{ }^{*}\right) \quad$ Teste ANOVA 1 fator. As barras correspondem ao intervalo de confiança 95\%.

${ }^{* *}$ NIT: Neuralgia Idiopática do Trigêmeo; DTM: Disfunção Temporomandibular; SAB: Síndrome da Ardência Bucal; DFIP: Dor Facial Idiopática Persistente; NPH: Neuralgia Pós-herpética; NPT: Neuropatia Pós-traumática; CC: Cefaléia Cervicogênica; PF: Paralisia facial; SW: Síndrome de Wallemberg. 
Figura 28 - $\quad$ Avaliação sensitiva quantitativa mecânica vibratória: valores médios e comparação entre os diagnósticos $(\mathrm{N}=123)$

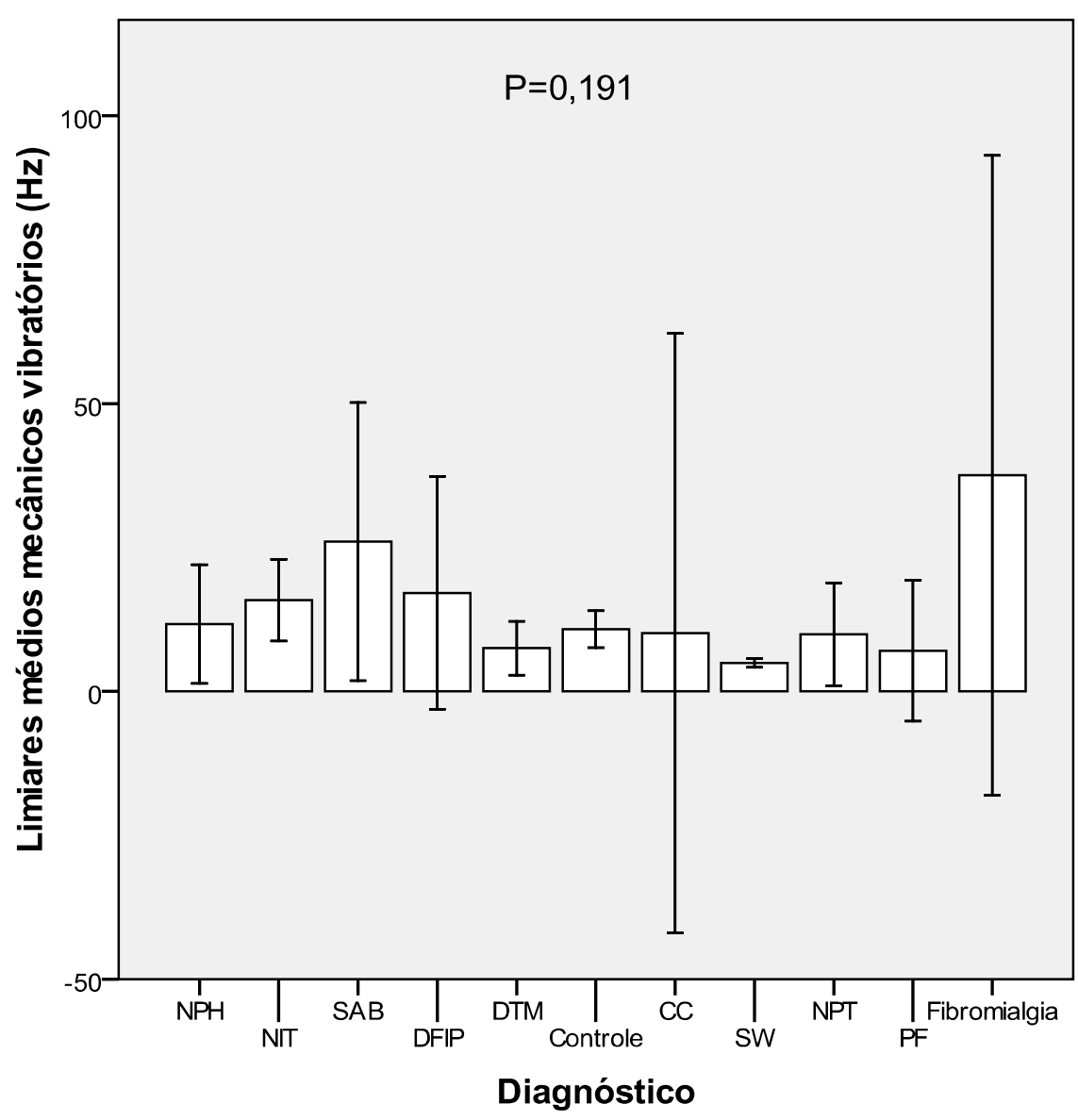

$\left(^{*}\right) \quad$ Teste ANOVA 1 fator. As barras correspondem ao intervalo de confiança 95\%.

$\left({ }^{* *}\right) \quad$ NIT: Neuralgia Idiopática do Trigêmeo; DTM: Disfunção Temporomandibular; SAB: Síndrome da Ardência Bucal; DFIP: Dor Facial Idiopática Persistente; NPH: Neuralgia Pós-herpética; NPT: Neuropatia Pós-traumática; CC: Cefaléia Cervicogênica; PF: Paralisia facial; SW: Síndrome de Wallemberg.

Os doentes com PF apresentaram limiares mecânicos elétricos maiores do que os controles $(p=0,034)$. Não houve diferenças nos limiares elétricos entre outros grupos (Figura 29). 
Figura 29 - $\quad$ Avaliação sensitiva quantitativa mecânica elétrica: valores médios e comparação entre os diagnósticos $(\mathrm{N}=123)$
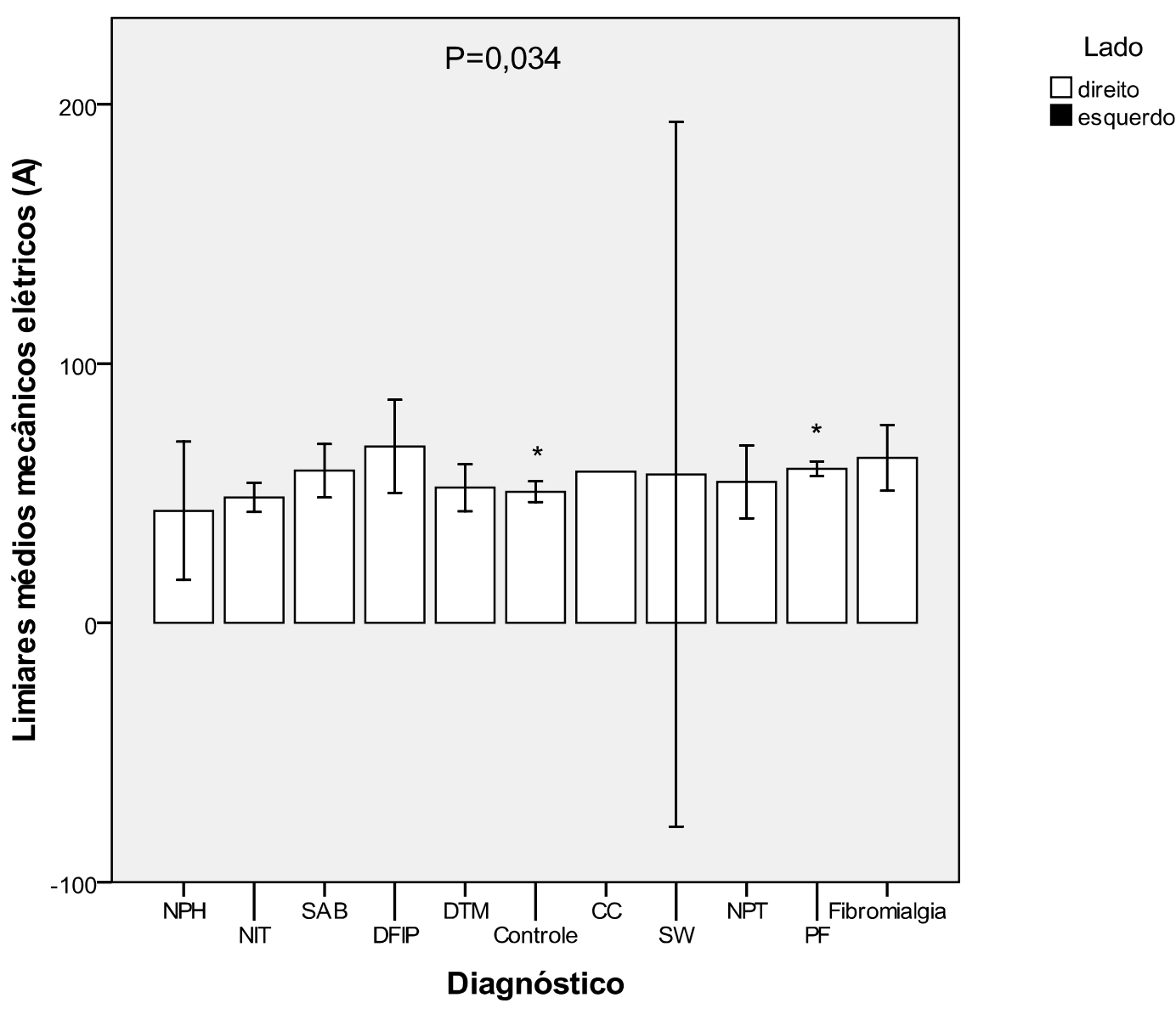

$\left.{ }^{*}\right)$ Teste ANOVA 1 fator, PostHoc: teste de Tukey. As barras correspondem ao intervalo de confiança $95 \%$.

${ }^{* *}$ NIT: Neuralgia Idiopática do Trigêmeo; DTM: Disfunção Temporomandibular; SAB: Síndrome da Ardência Bucal; DFIP: Dor Facial Idiopática Persistente; NPH: Neuralgia Pós-herpética; NPT: Neuropatia Pós-traumática; CC: Cefaléia Cervicogênica; PF: Paralisia facial; SW: Síndrome de Wallemberg.

Os limiares dolorosos de profundidade foram menores nos doentes com DTM e DFIP do que nos controles $(p=0,003)$ (Figura 30$)$. 
Figura 30 - $\quad$ Avaliação sensitiva quantitativa dolorosa de profundidade: valores médios e comparação entre os diagnósticos $(N=123)$

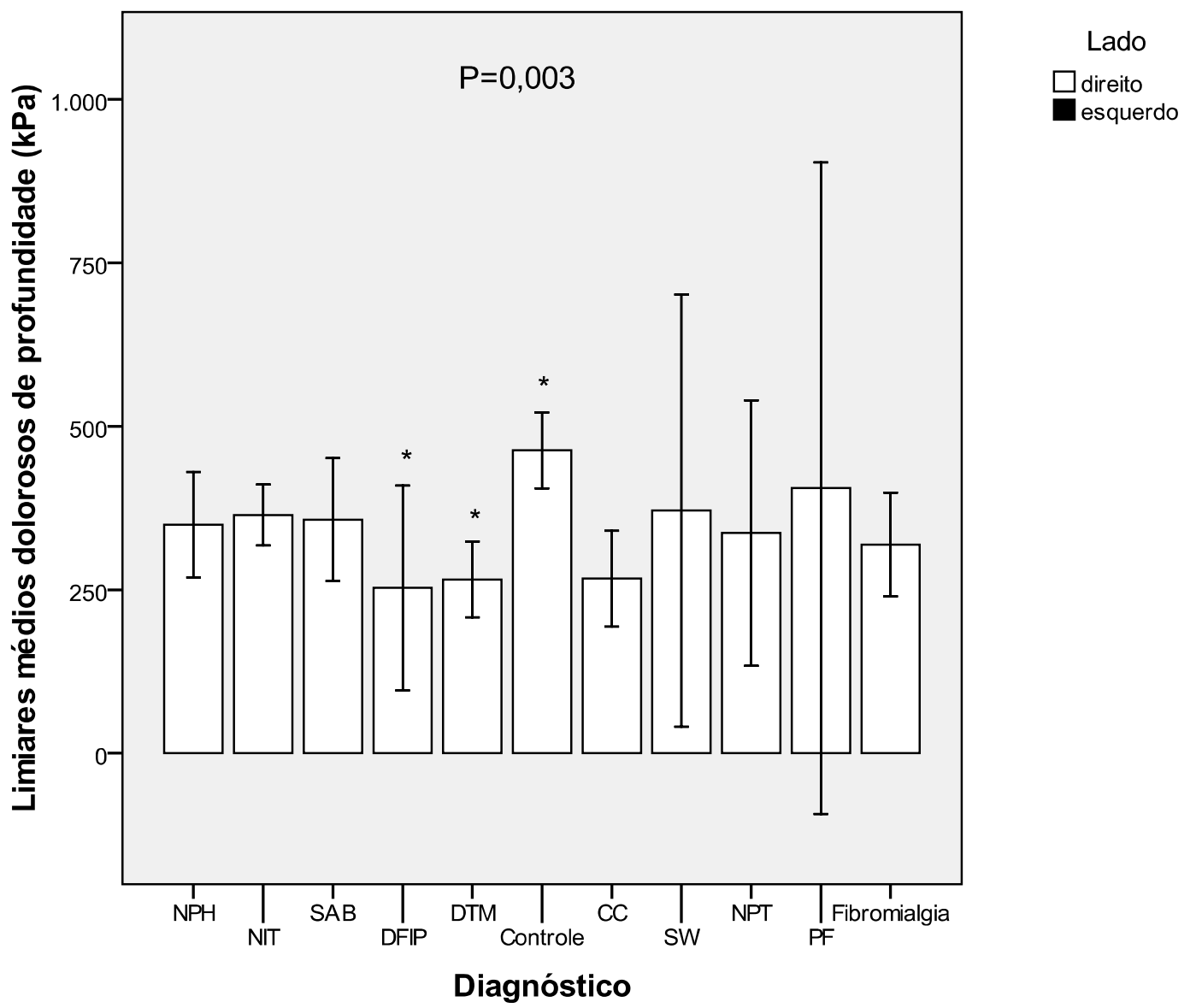

$\left(^{*}\right) \quad$ Teste ANOVA 1 fator, PostHoc: teste de Tukey. As barras correspondem ao intervalo de confiança $95 \%$.

$\left({ }^{* *}\right) \quad$ NIT: Neuralgia Idiopática do Trigêmeo; DTM: Disfunção Temporomandibular; SAB: Síndrome da Ardência Bucal; DFIP: Dor Facial Idiopática Persistente; NPH: Neuralgia Pós-herpética; NPT: Neuropatia Pós-traumática; CC: Cefaléia Cervicogênica; PF: Paralisia facial; SW: Síndrome de Wallemberg.

Os limiares dolorosos de superfície foram maiores nos doentes com fibromialgia do que nos controles $(p=0,016)$ (Figura 31). 
Figura 31 - Avaliação sensitiva quantitativa dolorosa de superfície: valores médios e comparação entre os diagnósticos $(N=123)$

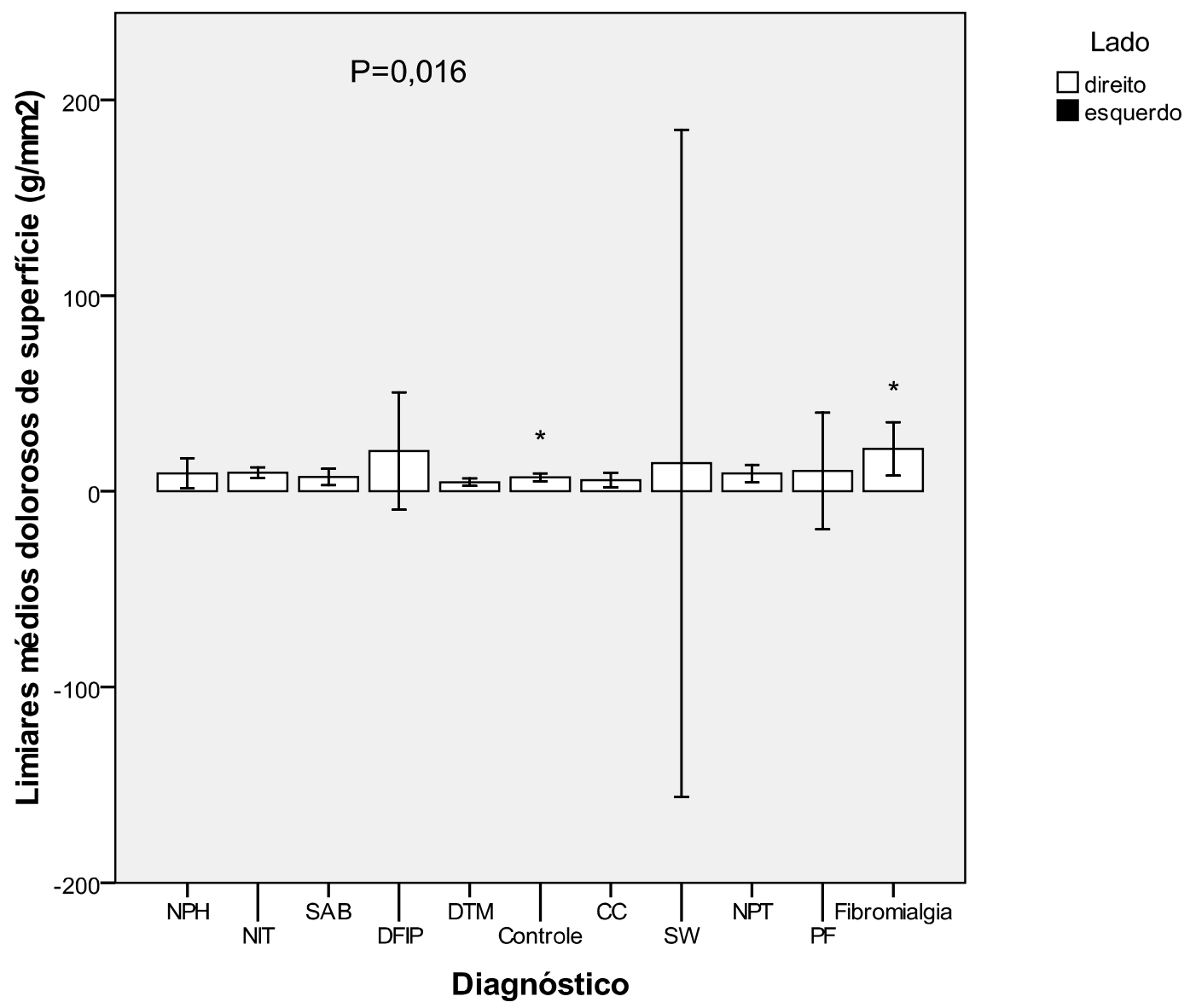

(*) Teste ANOVA 1 fator, PostHoc: teste de Tukey. As barras correspondem ao intervalo de confiança $95 \%$.

${ }^{* *}$ NIT: Neuralgia Idiopática do Trigêmeo; DTM: Disfunção Temporomandibular; SAB: Síndrome da Ardência Bucal; DFIP: Dor Facial Idiopática Persistente; NPH: Neuralgia Pós-herpética; NPT: Neuropatia Pós-traumática; CC: Cefaléia Cervicogênica; PF: Paralisia facial; SW: Síndrome de Wallemberg.

A média dos limiares dolorosos elétricos dentais foi calculada de acordo com os diagnósticos e não apresentaram diferenças estatísticas (Figura 32). 
Figura 32 - Avaliação sensitiva quantitativa elétrica dental: valores médios e comparação entre os diagnósticos $(\mathrm{N}=123)$

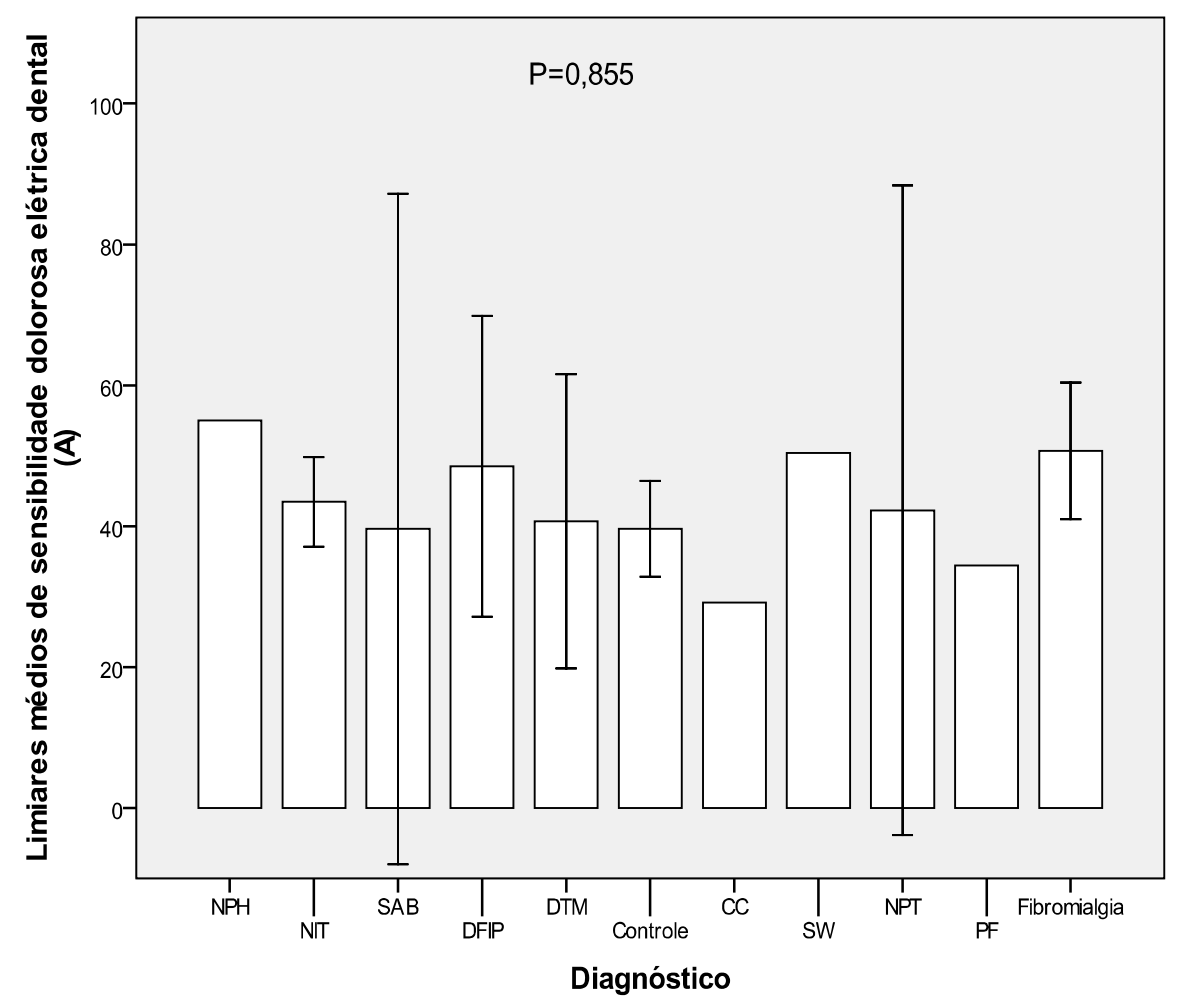

$\left.{ }^{*}\right) \quad$ Teste ANOVA 1 fator. As barras correspondem ao intervalo de confiança 95\%.

$\left(^{* *}\right.$ NIT: Neuralgia Idiopática do Trigêmeo; DTM: Disfunção Temporomandibular; SAB: Síndrome da Ardência Bucal; DFIP: Dor Facial Idiopática Persistente; NPH: Neuralgia Pós-herpética; NPT: Neuropatia Pós-traumática; CC: Cefaléia Cervicogênica; PF: Paralisia facial; SW: Síndrome de Wallemberg.

As figuras 33 a 39 apresentam os dados de cada modalidade sensitiva de acordo com o ramo trigeminal avaliado. Na avaliação térmica ao frio, apenas o ramo oftálmico apresentou diferenças entre os grupos $(p=0,006)$. Os doentes com DTM tiveram limiares menores e os doentes com $\mathrm{NPH}$ tiveram limiares maiores do que os controles (Figura 33). 
Figura 33 - $\quad$ Avaliação sensitiva quantitativa térmica (frio): comparação entre os lados de acordo com o ramo trigeminal $(\mathrm{N}=123)$
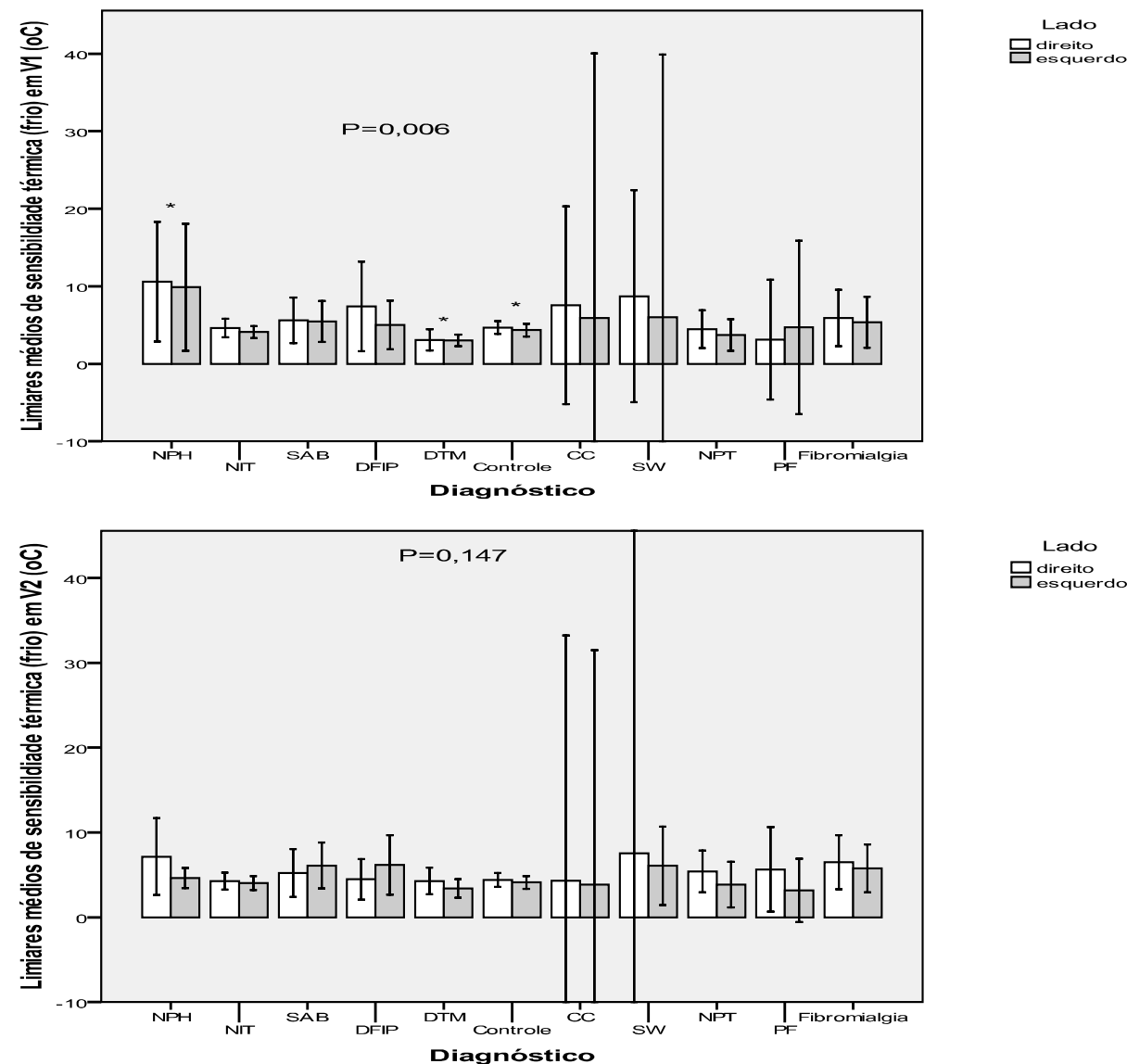

Lado

口

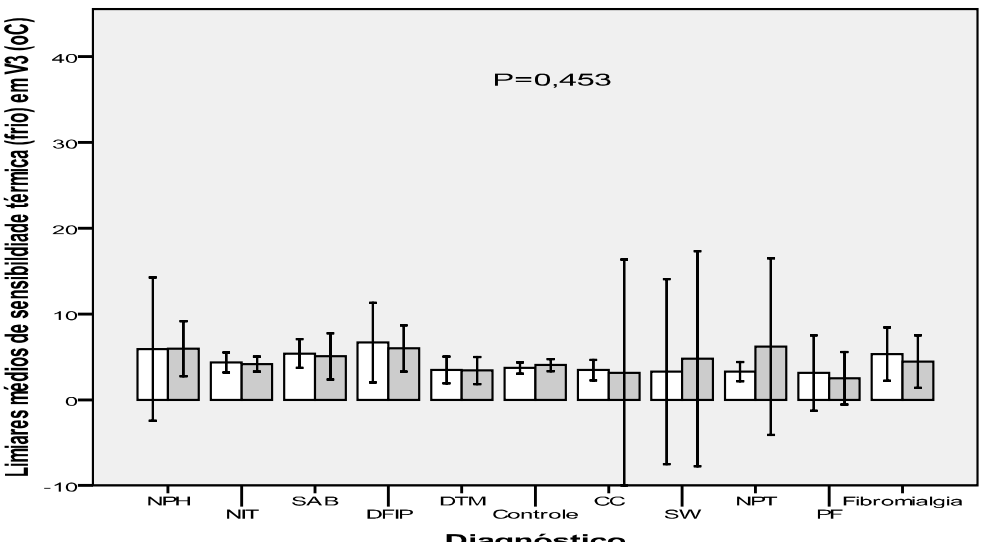

Lado

吕 direito

Diagnóstico

${ }^{*}$ Teste ANOVA 1 fator, PostHoc: teste de Tukey. As barras correspondem ao intervalo de confiança 95\%

$\left.{ }^{* *}\right) \quad$ NIT: Neuralgia Idiopática do Trigêmeo; DTM: Disfunção Temporomandibular; SAB: Síndrome da Ardência Bucal; DFIP: Dor Facial Idiopática Persistente; NPH: Neuralgia Pós-herpética; NPT: Neuropatia Pós-traumática; CC: Cefaléia Cervicogênica; PF: Paralisia facial; SW: Síndrome de Wallemberg

$\left(^{* * *}\right) \quad$ V1: ramo oftálmico; V2: ramo maxilar; V3: ramo mandibular. 
Não houve diferenças entre os grupos com relação aos limiares térmicos ao calor (Figura 34) ou aos limiares mecânicos tácteis (Figura 35) em nenhum dos ramos trigeminais, ou ainda nos limiares mecânicos vibratórios (Figura 36).

Os limiares mecânicos elétricos no ramo mandibular esquerdo foram menores do que os controles nos doentes com NIT $(p=0,027)$ (Figura 37).

Os doentes com DTM apresentaram limiares dolorosos de profundidade menores do que os controles nas regiões temporais $(p=0,015)$ e massetéricos $(p=0,008)$ (Figura 38).

Os doentes com NIT apresentaram limiares dolorosos de superfície maiores do que os controles na região do ramo mandibular $(p=0,048)$. Não houve outras diferenças estatísticas entre os grupos ou em outros ramos trigeminais (Figura 39). 
Figura 34 - $\quad$ Avaliação sensitiva quantitativa térmica (calor): comparação entre os lados de acordo com o ramo trigeminal $(N=123)$

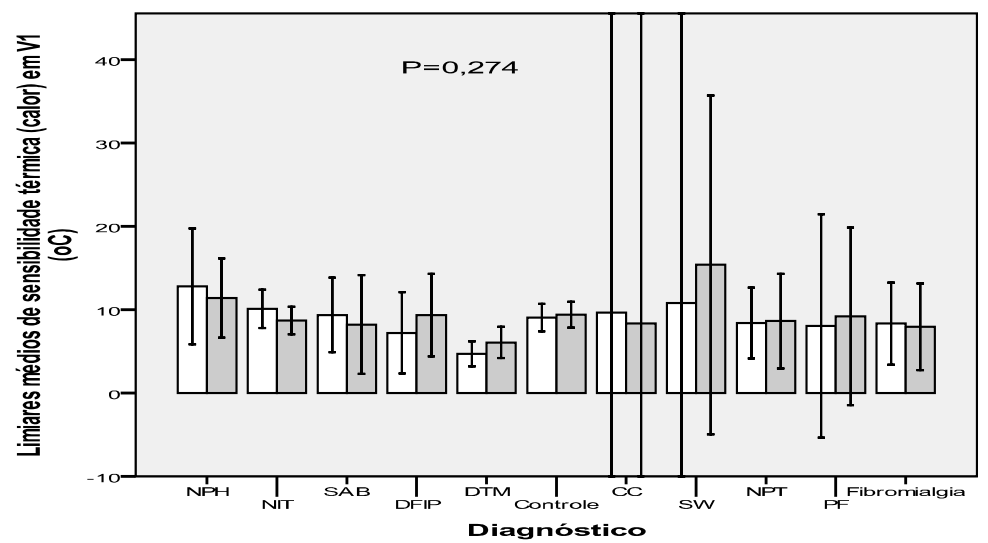

Lado
吕 direito
esquerdo

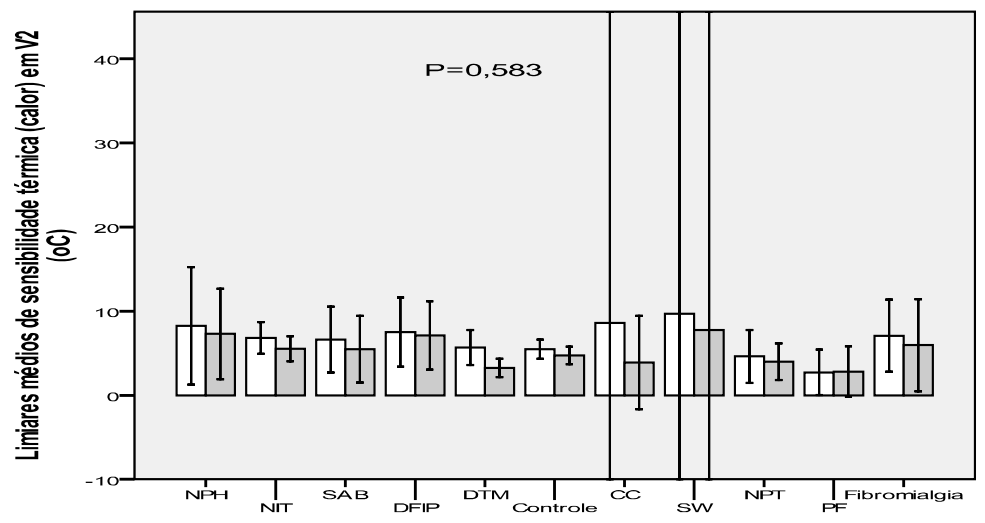

Lado

$\square$ direito

Diagnóstico

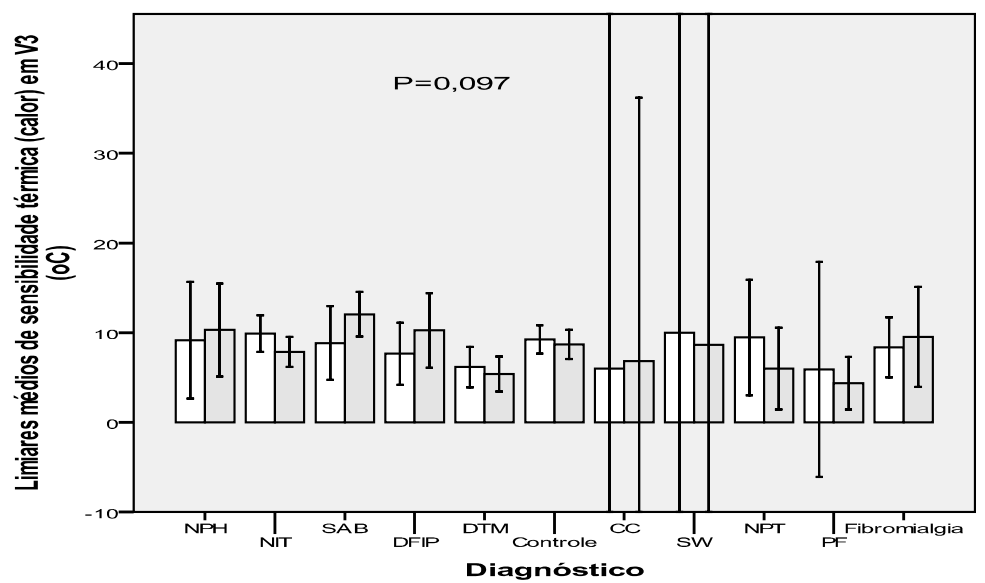

Lado

$\left.{ }^{*}\right) \quad$ Teste ANOVA 1 fator. As barras correspondem ao intervalo de confiança $95 \%$

$\left(^{* *}\right.$ NIT: Neuralgia Idiopática do Trigêmeo; DTM: Disfunção Temporomandibular; SAB: Síndrome da Ardência Bucal; DFIP: Dor Facial Idiopática Persistente; NPH: Neuralgia Pós-herpética; NPT: Neuropatia Pós-traumática; CC: Cefaléia Cervicogênica; PF: Paralisia facial; SW: Síndrome de Wallemberg.

$\left.{ }^{(* *}\right) \quad$ V1: ramo oftálmico; V2: ramo maxilar; V3: ramo mandibular. 
Figura 35 - $\quad$ Avaliação sensitiva quantitativa mecânica táctil: comparação entre os lados de acordo com o ramo trigeminal $(\mathrm{N}=123)$
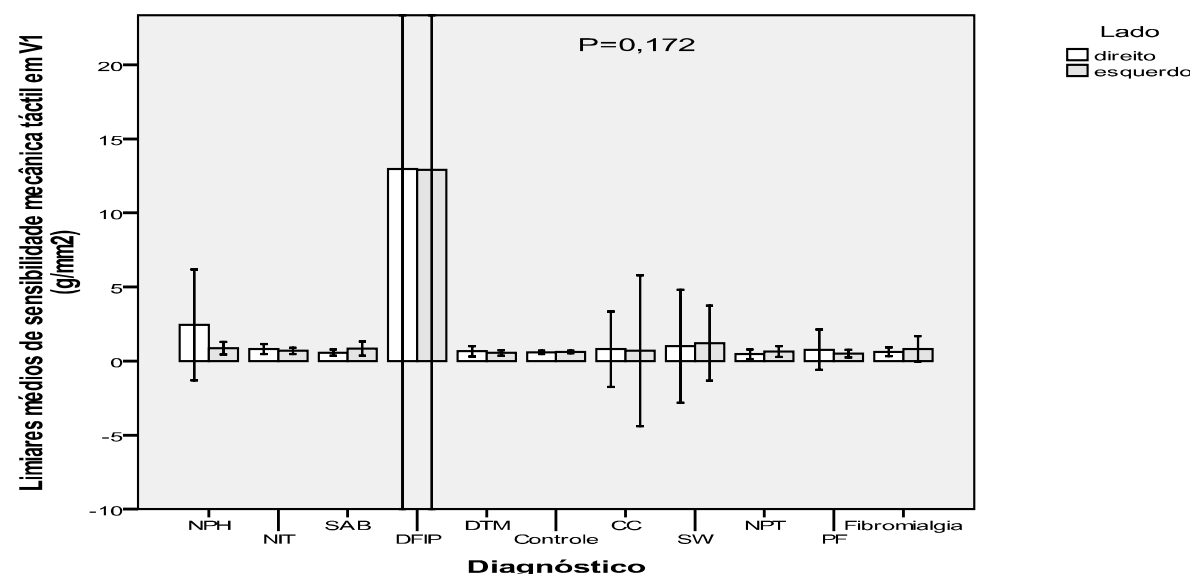

$\square$ direito

Diagnóstico

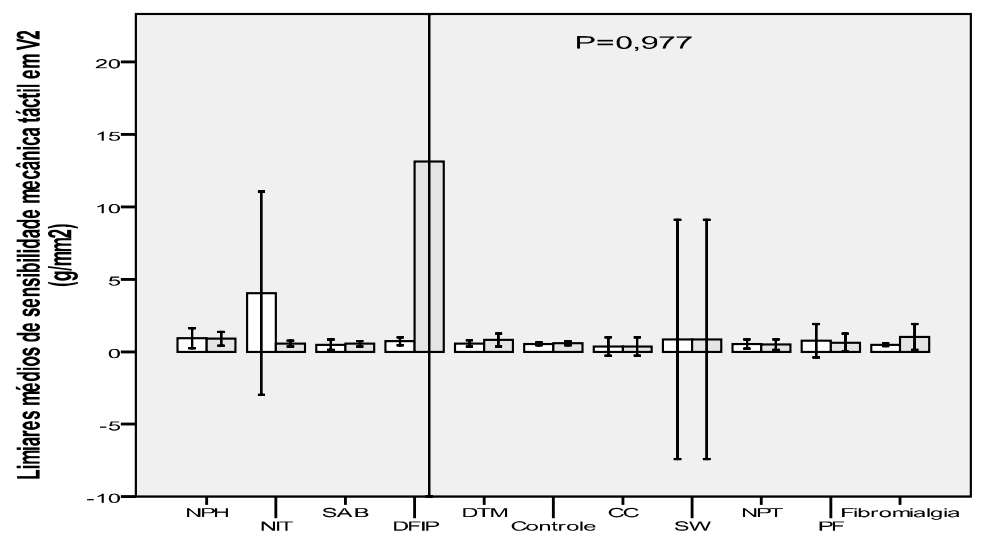

Lado

$\square$ direito

Diagnóstico

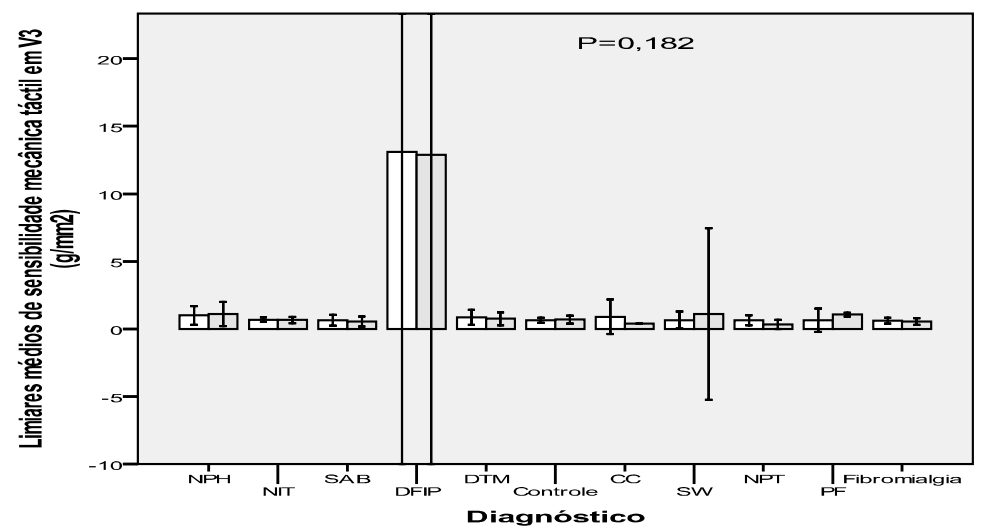

Lado

$\left(^{*}\right)$ Teste ANOVA 1 fator. As barras correspondem ao intervalo de confiança 95\%

$\left({ }^{* *}\right) \quad$ NIT: Neuralgia Idiopática do Trigêmeo; DTM: Disfunção Temporomandibular; SAB: Síndrome da Ardência Bucal; DFIP: Dor Facial Idiopática Persistente; NPH: Neuralgia Pós-herpética; NPT: Neuropatia Pós-traumática; CC: Cefaléia Cervicogênica; PF: Paralisia facial; SW: Síndrome de Wallemberg.

$\left(^{* * *}\right) \quad$ V1: ramo oftálmico; V2: ramo maxilar; V3: ramo mandibular. 
Figura 36 - Avaliação sensitiva quantitativa mecânica vibratória: comparação entre os lados de acordo com o ramo trigeminal $(\mathrm{N}=123)$
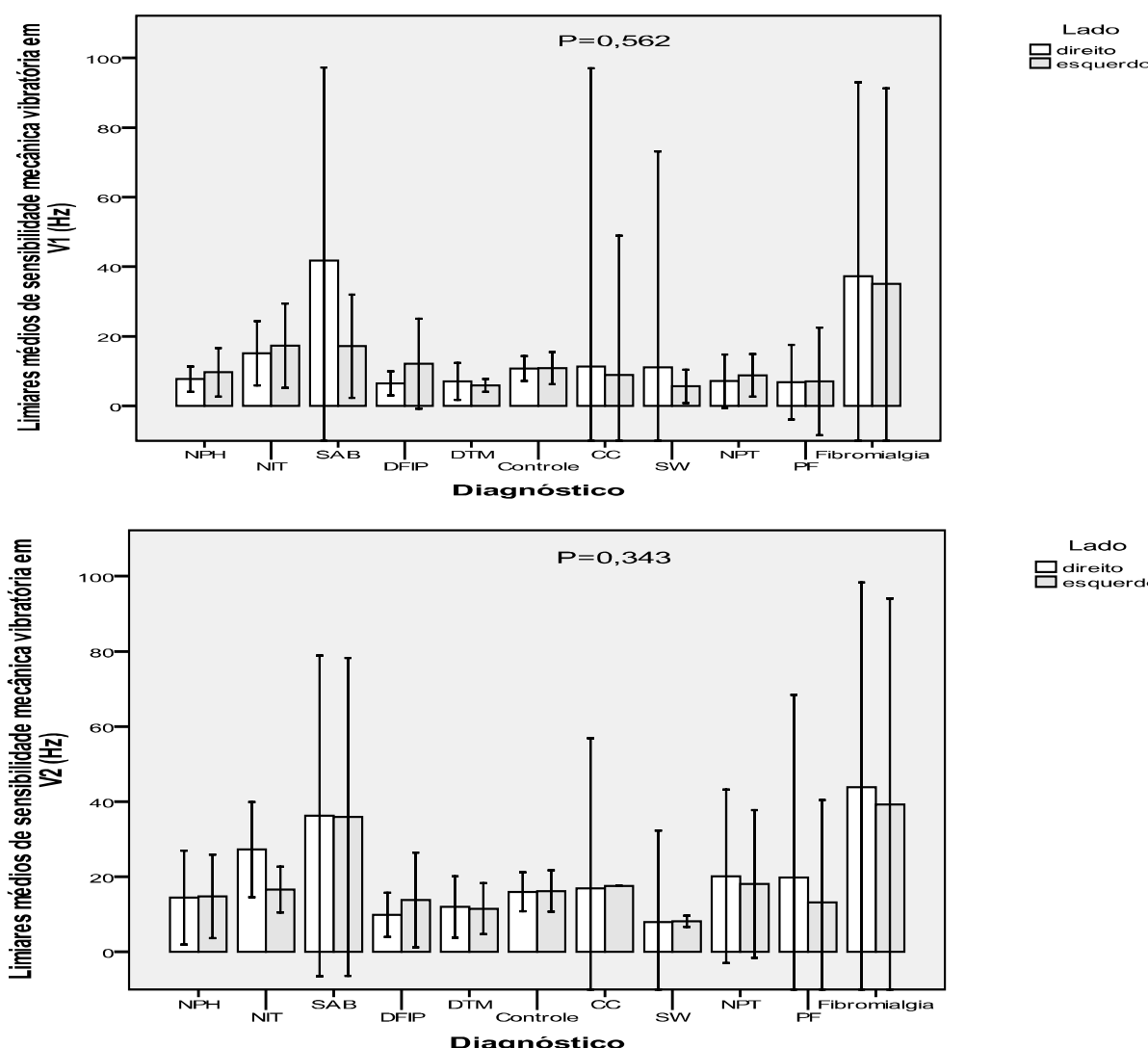

Diagnóstico

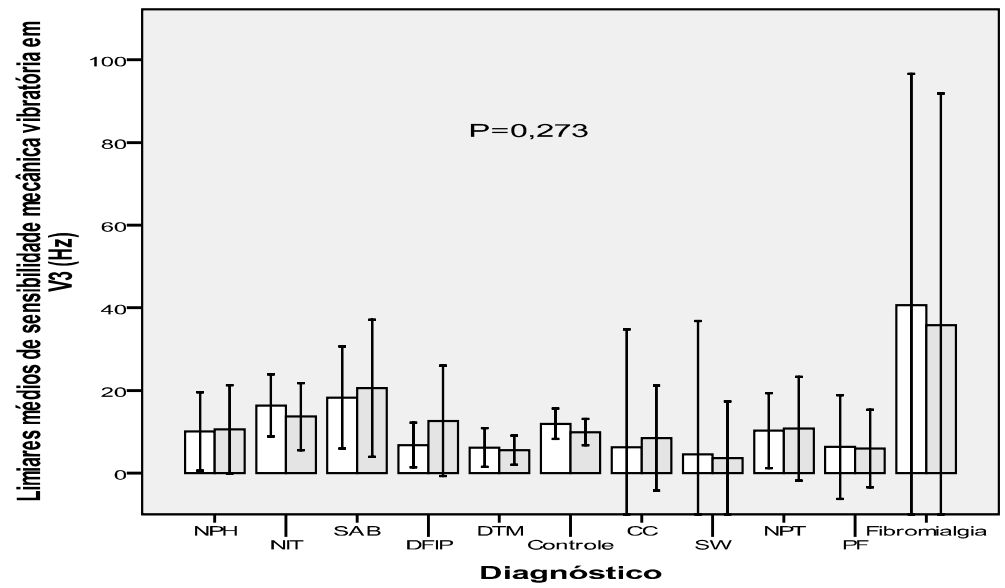

$\left.{ }^{*}\right) \quad$ Teste ANOVA 1 fator. As barras correspondem ao intervalo de confiança 95\%

$\left({ }^{* *}\right) \quad$ NIT: Neuralgia Idiopática do Trigêmeo; DTM: Disfunção Temporomandibular; SAB: Síndrome da Ardência Bucal; DFIP: Dor Facial Idiopática Persistente; NPH: Neuralgia Pós-herpética; NPT: Neuropatia Pós-traumática; CC: Cefaléia Cervicogênica; PF: Paralisia facial; SW: Síndrome de Wallemberg.

$\left(^{* * *}\right) \quad$ V1: ramo oftálmico; V2: ramo maxilar; V3: ramo mandibular. 
Figura 37 - Avaliação sensitiva quantitativa mecânica elétrica: comparação entre os lados de acordo com o ramo trigeminal $(\mathrm{N}=123)$
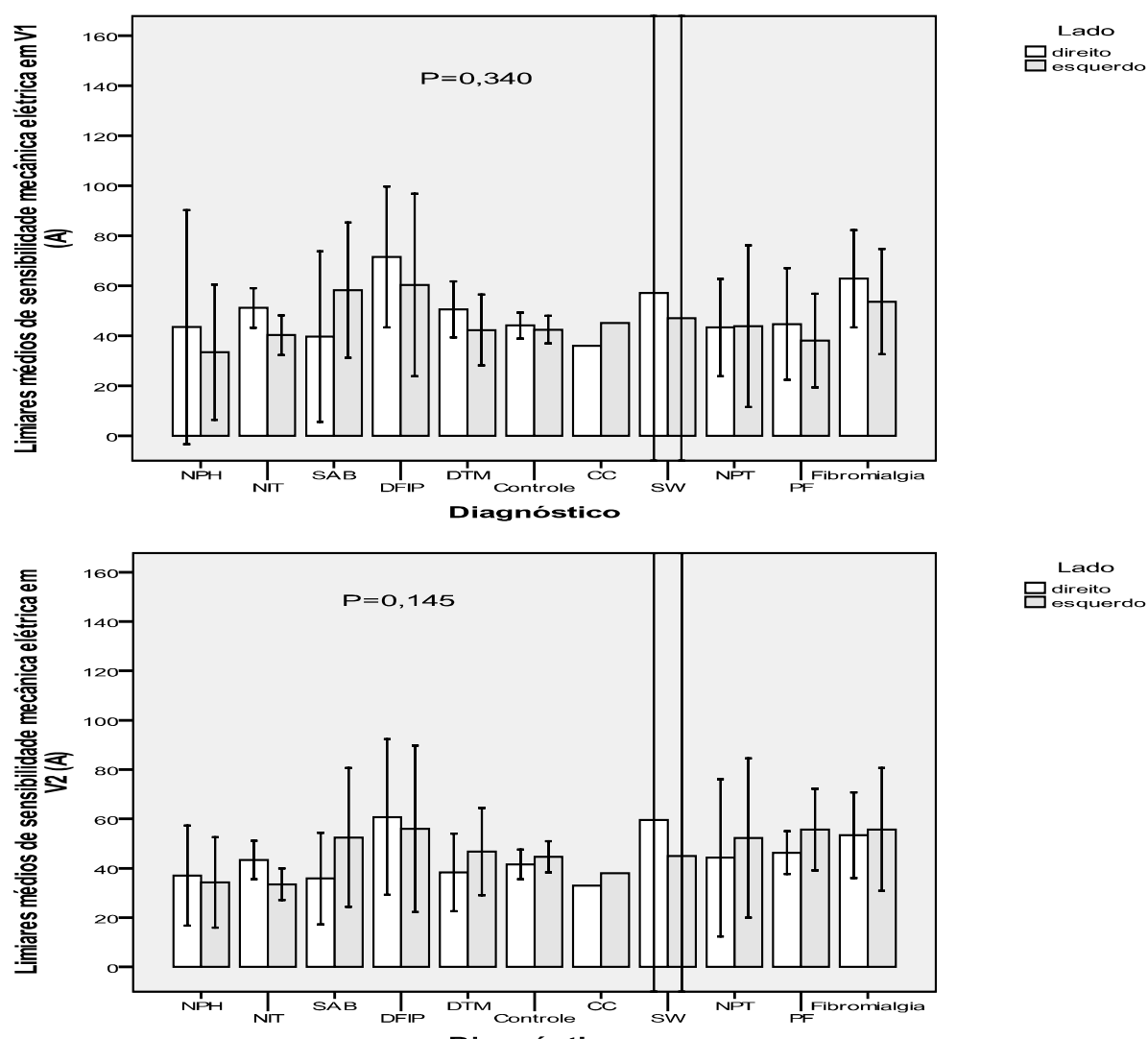

Lado
direito
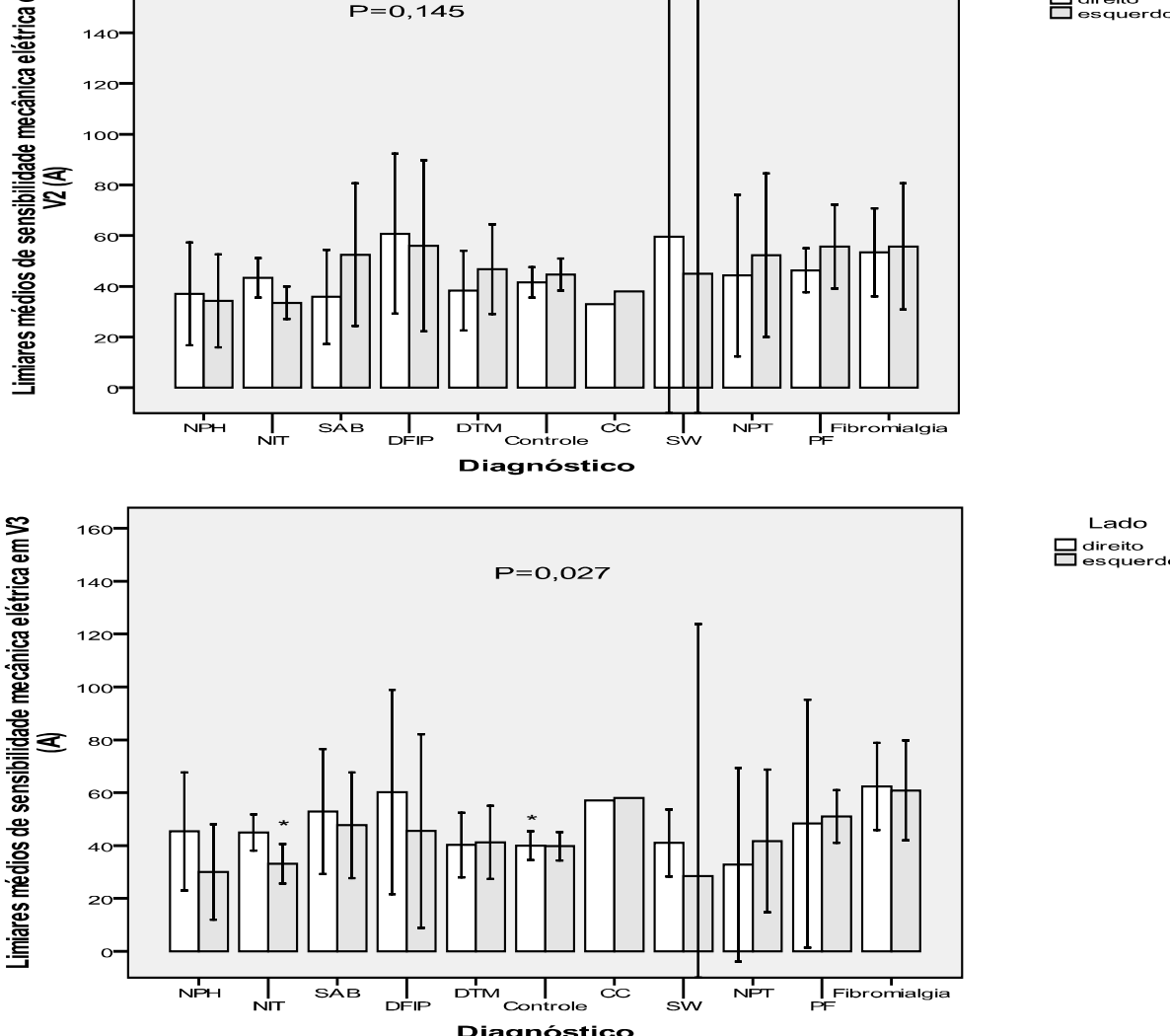

Lado

吕 direito

$\left(^{*}\right) \quad$ Teste ANOVA 1 fator, PostHoc: teste de Tukey. As barras correspondem ao intervalo de confiança $95 \%$

$\left({ }^{* *}\right) \quad$ NIT: Neuralgia Idiopática do Trigêmeo; DTM: Disfunção Temporomandibular; SAB: Síndrome da Ardência Bucal; DFIP: Dor Facial Idiopática Persistente; NPH: Neuralgia Pós-herpética; NPT: Neuropatia Pós-traumática; CC: Cefaléia Cervicogênica; PF: Paralisia facial; SW: Síndrome de Wallemberg.

$\left.{ }^{(* *}\right) \quad$ V1: ramo oftálmico; V2: ramo maxilar; V3: ramo mandibular. 
Figura 38 - $\quad$ Avaliação sensitiva quantitativa dolorosa de profundidade: comparação entre os lados de acordo com o local em face $(\mathrm{N}=123)$

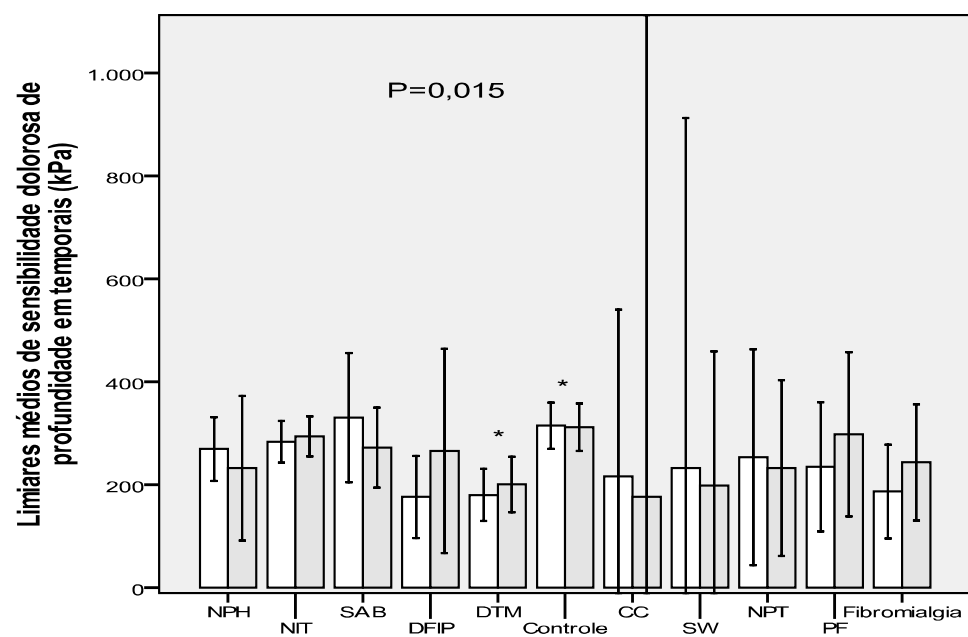

Lado
$\square$ direito

$\square$ direito

Diagnóstico

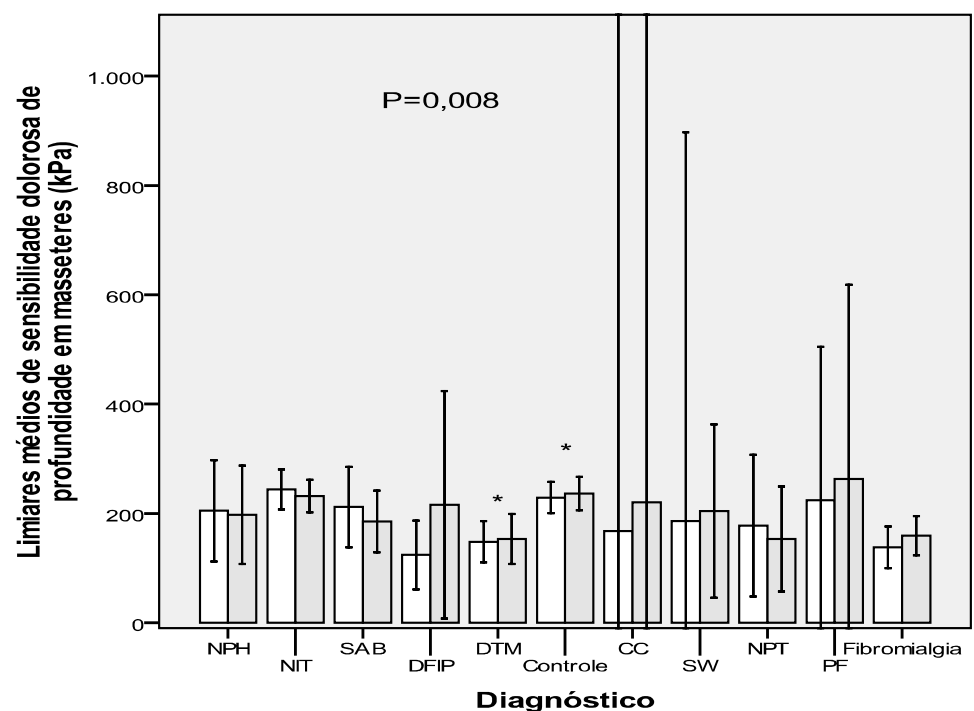

Lado

$\longmapsto$ direito

$\left(^{*}\right)$ Teste ANOVA 1 fator, PostHoc: teste de Tukey. As barras correspondem ao intervalo de confiança $95 \%$

$\left({ }^{* *}\right) \quad$ NIT: Neuralgia Idiopática do Trigêmeo; DTM: Disfunção Temporomandibular; SAB: Síndrome da Ardência Bucal; DFIP: Dor Facial Idiopática Persistente; NPH: Neuralgia Pós-herpética; NPT: Neuropatia Pós-traumática; CC: Cefaléia Cervicogênica; PF: Paralisia facial; SW: Síndrome de Wallemberg. 
Figura 39 - Avaliação sensitiva quantitativa dolorosa de superfície: comparação entre os lados de acordo com o ramo trigeminal $(\mathrm{N}=123)$

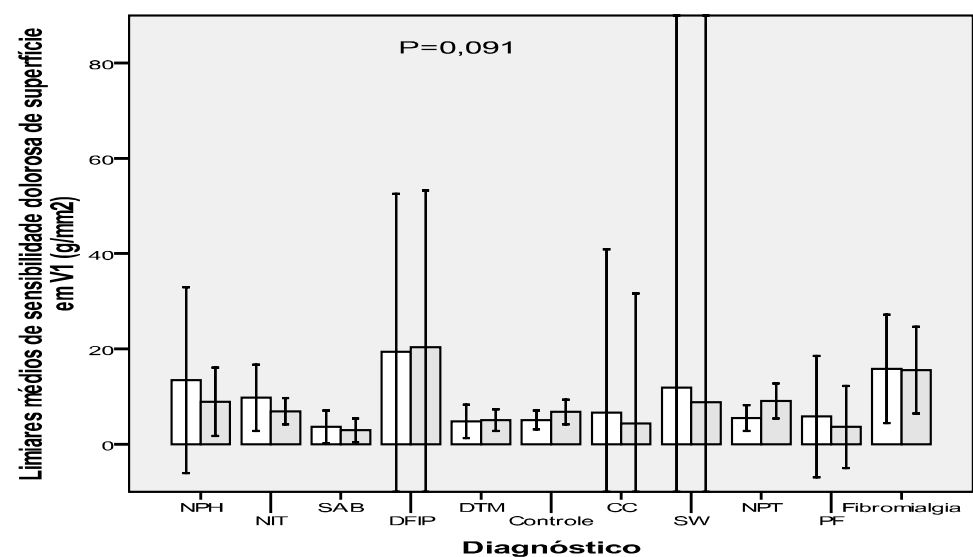

Lado
豆ireito
esquerdo

Diagnóstico

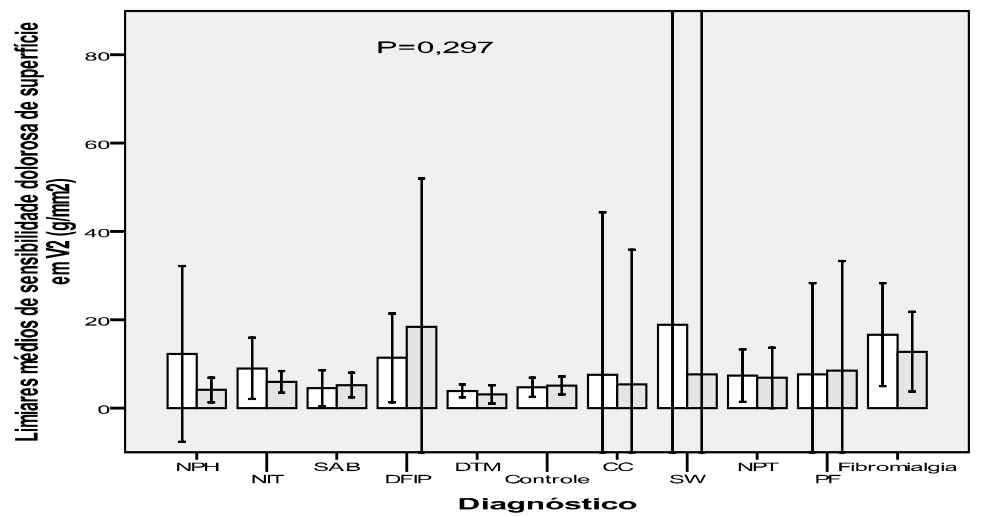

Lado
Daireito
esquerdo

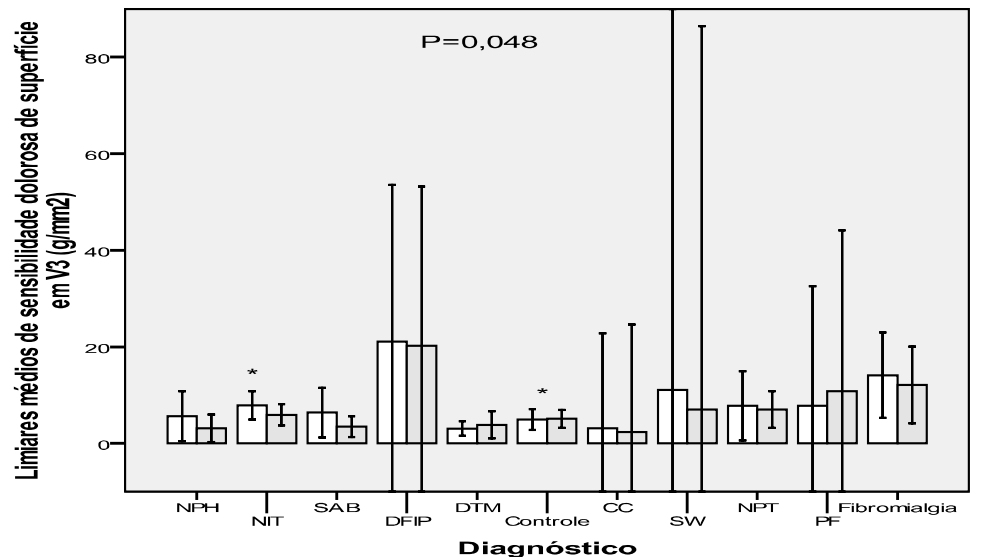

Lado

马 gireito

Diagnóstico

$\left(^{*}\right) \quad$ Teste ANOVA 1 fator, PostHoc: teste de Tukey. As barras correspondem ao intervalo de confiança $95 \%$

$\left.{ }^{* *}\right) \quad$ NIT: Neuralgia Idiopática do Trigêmeo; DTM: Disfunção Temporomandibular; SAB: Síndrome da Ardência Bucal; DFIP: Dor Facial Idiopática Persistente; NPH: Neuralgia Pós-herpética; NPT: Neuropatia Pós-traumática; CC: Cefaléia Cervicogênica; PF: Paralisia facial; SW: Síndrome de Wallemberg.

$\left.{ }^{* * *}\right) \quad$ V1: ramo oftálmico; V2: ramo maxilar; V3: ramo mandibular. 
As figuras 40 a 46 apresentam os dados de cada modalidade sensitiva de acordo com o local (mão ou tíbia) avaliado.

Os limiares térmicos ao frio foram maiores nos doentes com SAB nas mãos $(p<0,001)$ e na tíbia $(p=0,029)$ do que os controles (Figura 40). Não houve diferenças nos limiares ao calor (Figura 41).

Os doentes com DTM apresentaram limiares mecânicos tácteis em mãos menores do que os controles $(p=0,007)$ e os doentes com NPH apresentaram limiares mecânicos tácteis em tíbia maiores do que os controles $(p=0,006)$ (Figura 42).

Os limiares mecânicos vibratórios em mãos foram menores do que os controles nos doentes com DTM; não houve diferenças entre os grupos quanto aos limiares mecânicos vibratórios em tíbia (Figura 43) nem quanto aos limiares mecânicos elétricos em mãos ou tíbia (Figura 44).

Os limiares dolorosos de profundidade foram menores nas mãos nos doentes com NPH, NIT, DTM e fibromialgia quando comparados aos controles ( $p=0,035)$; na tíbia, apenas os limiares dos doentes com DTM foram menores do que os controles $(p=0,050)$ (Figura 45).

Doentes que apresentavam fibromialgia tiveram limiares dolorosos de superfície maiores do que os controles tanto em mãos $(p=0,037)$ como em tíbias $(p=0,002)$ (Figura 46). 
Figura 40 - $\quad$ Avaliação sensitiva quantitativa térmica (frio): comparação entre os lados de acordo com o local (mãos ou tíbia) $(\mathrm{N}=123)$

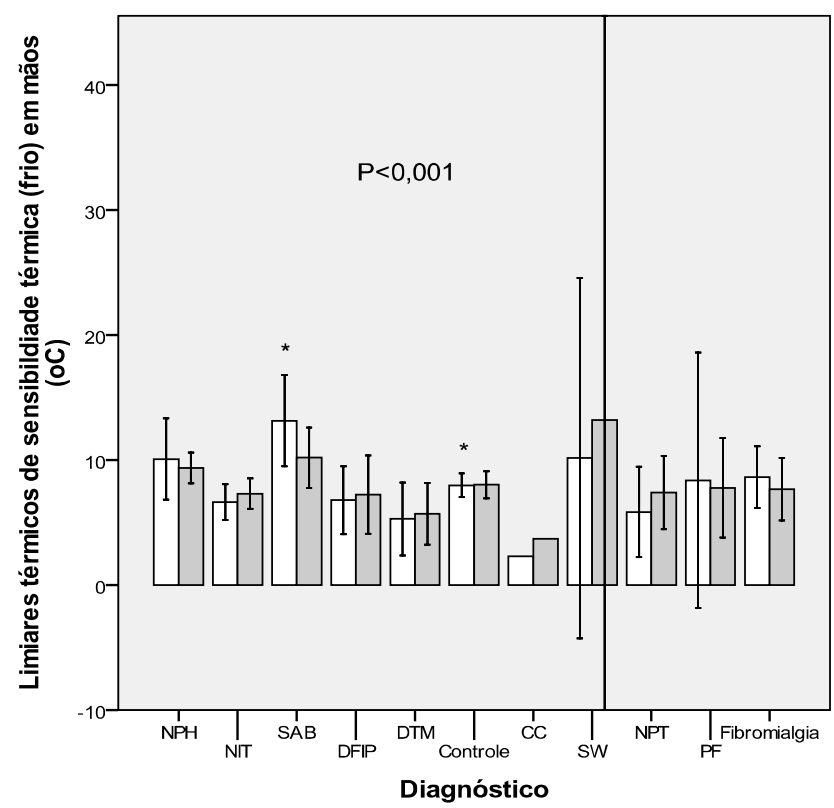

$$
\begin{gathered}
\text { Lado } \\
\square \text { direito } \\
\square \text { esquerdo }
\end{gathered}
$$

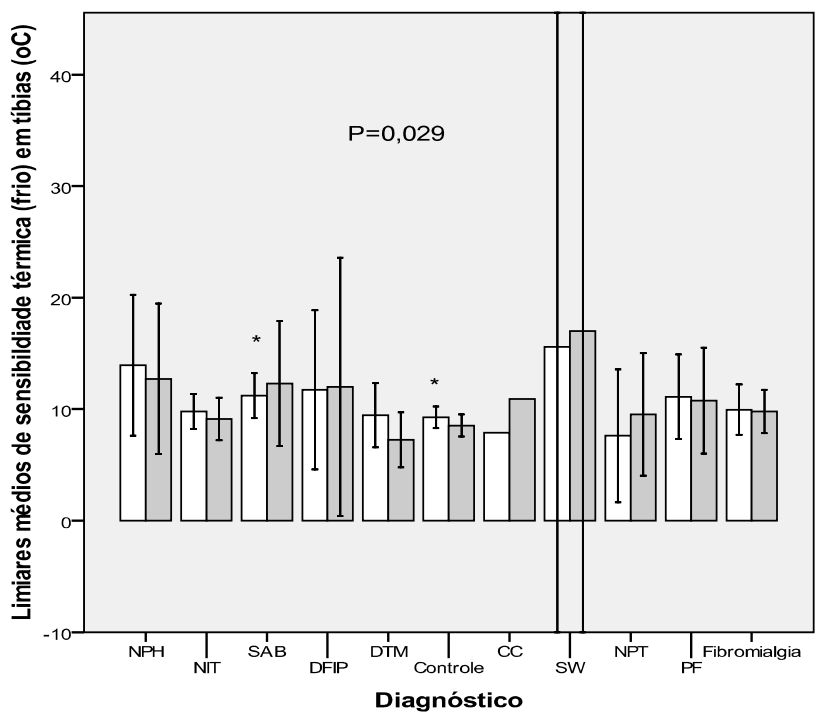

$\left.{ }^{*}\right)$ Teste ANOVA 1 fator, PostHoc: teste de Tukey. As barras correspondem ao intervalo de confiança $95 \%$

$\left({ }^{* *}\right) \quad$ NIT: Neuralgia Idiopática do Trigêmeo; DTM: Disfunção Temporomandibular; SAB: Síndrome da Ardência Bucal; DFIP: Dor Facial Idiopática Persistente; NPH: Neuralgia Pós-herpética; NPT: Neuropatia Pós-traumática; CC: Cefaléia Cervicogênica; PF: Paralisia facial; SW: Síndrome de Wallemberg. 
Figura 41 - Avaliação sensitiva quantitativa térmica (calor): comparação entre os lados de acordo com o local (mãos ou tíbia) $(\mathrm{N}=123)$

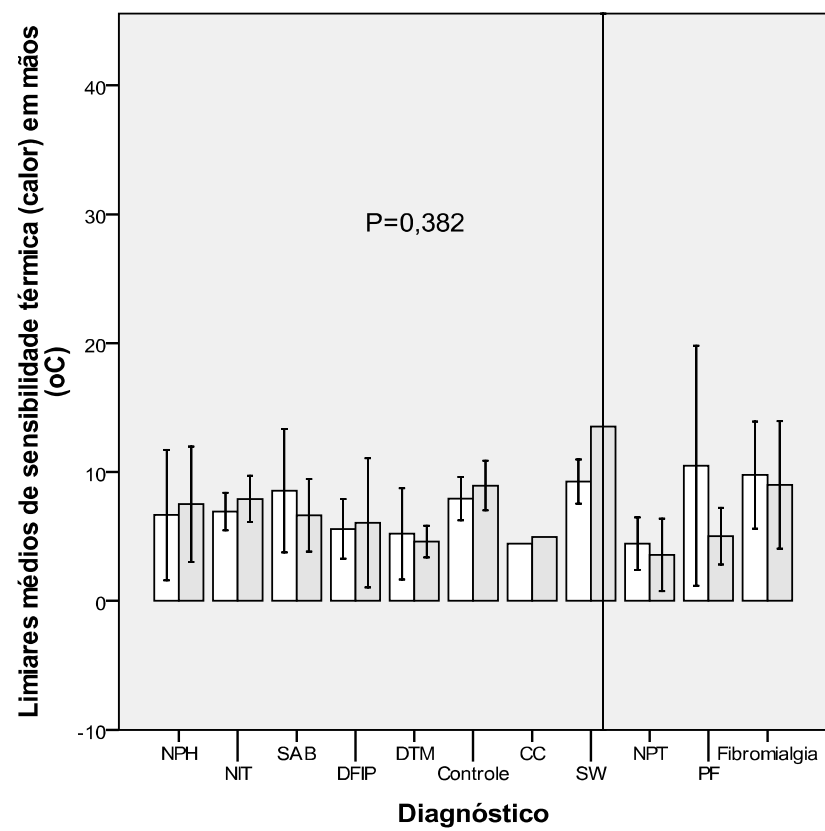

$$
\begin{gathered}
\text { Lado } \\
\square \text { direito } \\
\square \text { esquerdo }
\end{gathered}
$$

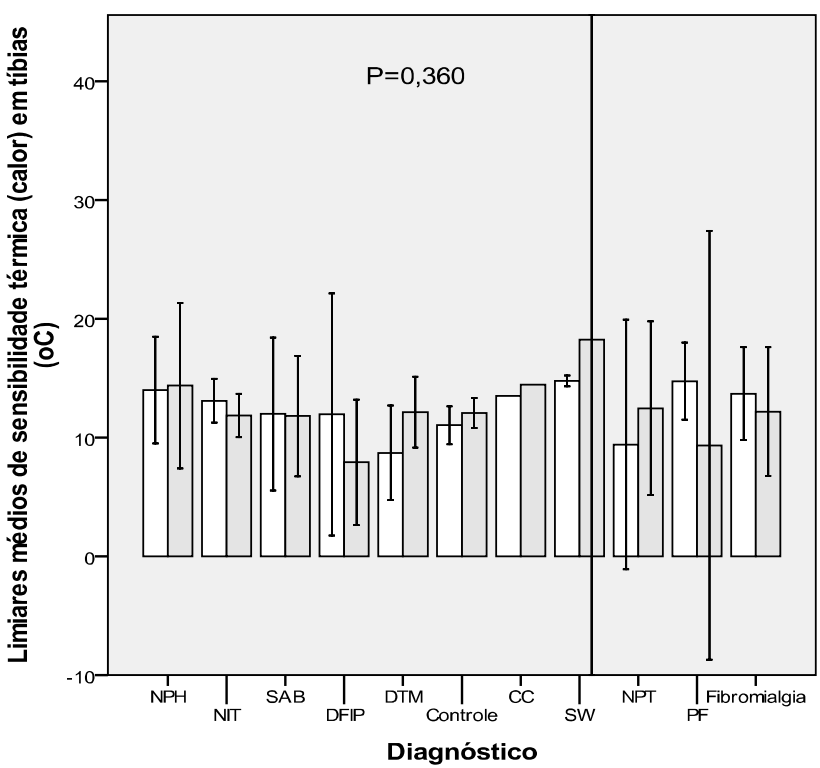

Lado

$\sqsupseteq$ direito

$\square$ esquerdo

$\left(^{*}\right) \quad$ Teste ANOVA 1 fator, PostHoc: teste de Tukey. As barras correspondem ao intervalo de confiança $95 \%$

$\left({ }^{* *}\right) \quad$ NIT: Neuralgia Idiopática do Trigêmeo; DTM: Disfunção Temporomandibular; SAB: Síndrome da Ardência Bucal; DFIP: Dor Facial Idiopática Persistente; NPH: Neuralgia Pós-herpética; NPT: Neuropatia Pós-traumática; CC: Cefaléia Cervicogênica; PF: Paralisia facial; SW: Síndrome de Wallemberg. 
Figura 42 - $\quad$ Avaliação sensitiva quantitativa mecânica táctil: comparação entre os lados de acordo com o local (mãos ou tíbia) $(\mathrm{N}=123)$

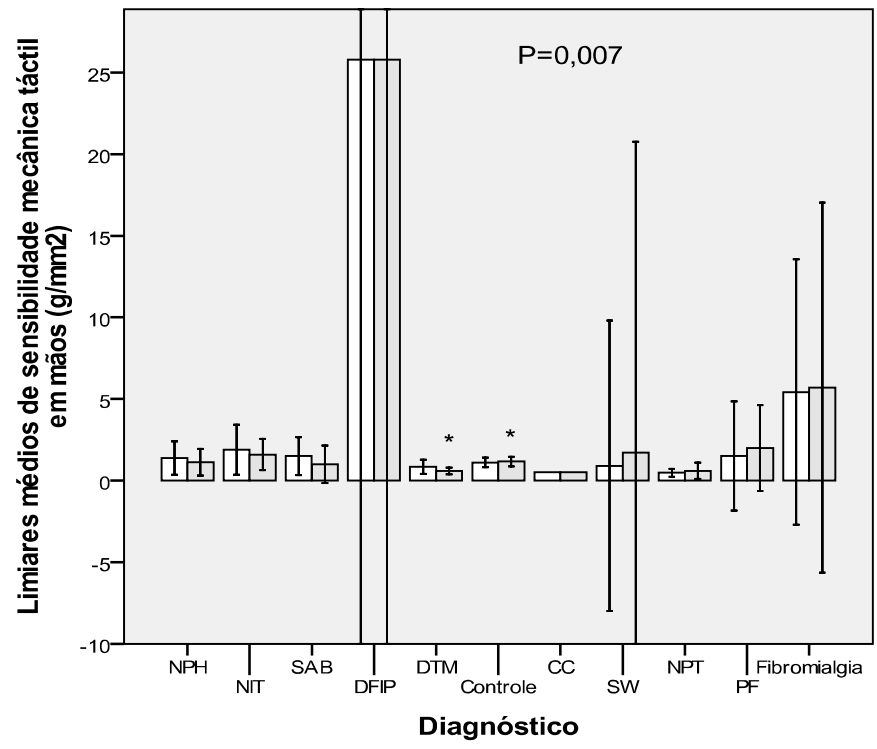

$$
\begin{gathered}
\text { Lado } \\
\square \text { direito } \\
\square \text { esquerdo }
\end{gathered}
$$

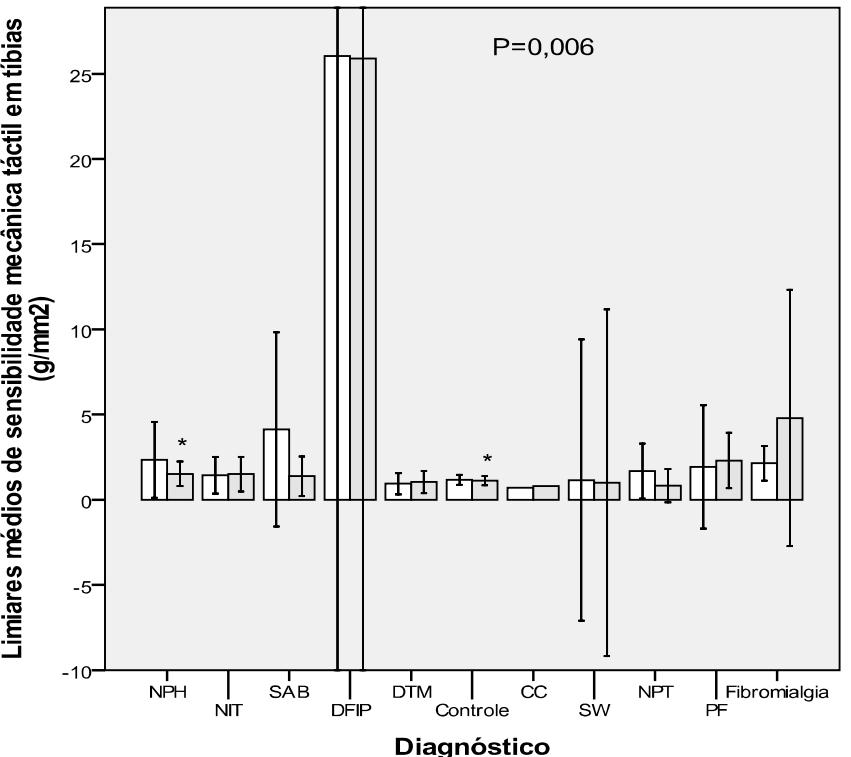

Lado

$\square$ direito

(1)

$\left({ }^{*}\right) \quad$ Teste ANOVA 1 fator, PostHoc: teste de Tukey. As barras correspondem ao intervalo de confiança $95 \%$

$\left.{ }^{* *}\right) \quad$ NIT: Neuralgia Idiopática do Trigêmeo; DTM: Disfunção Temporomandibular; SAB: Síndrome da Ardência Bucal; DFIP: Dor Facial Idiopática Persistente; NPH: Neuralgia Pós-herpética; NPT: Neuropatia Pós-traumática; CC: Cefaléia Cervicogênica; PF: Paralisia facial; SW: Síndrome de Wallemberg. 
Figura 43 - Avaliação sensitiva quantitativa mecânica vibratória: comparação entre os lados de acordo com o local (mãos ou tíbia) ( $\mathrm{N}=123)$

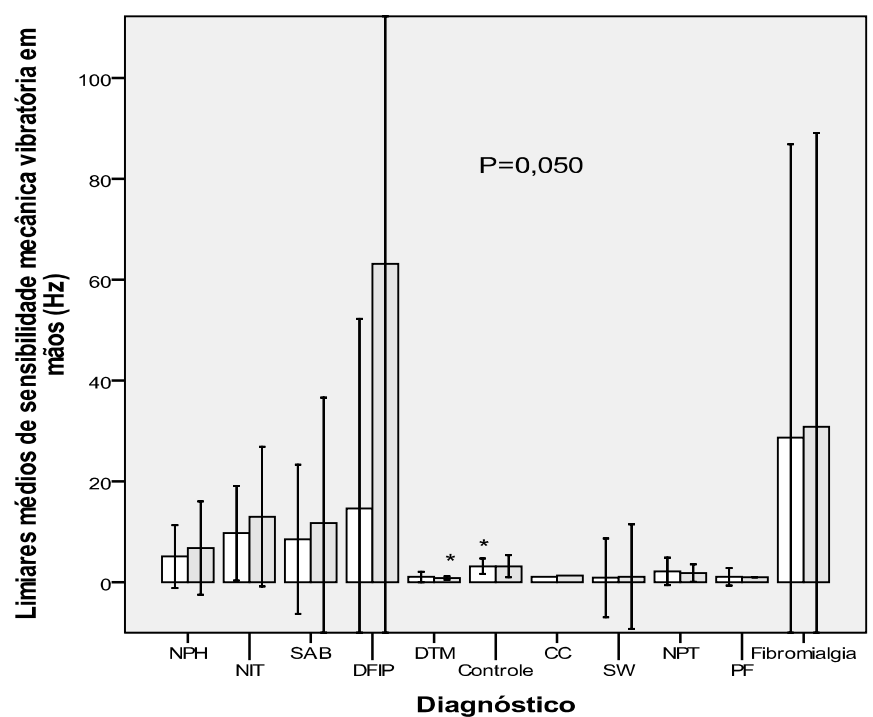

$$
\begin{gathered}
\text { Lado } \\
\square \text { direito } \\
\square \text { esquerdo }
\end{gathered}
$$

Diagnóstico

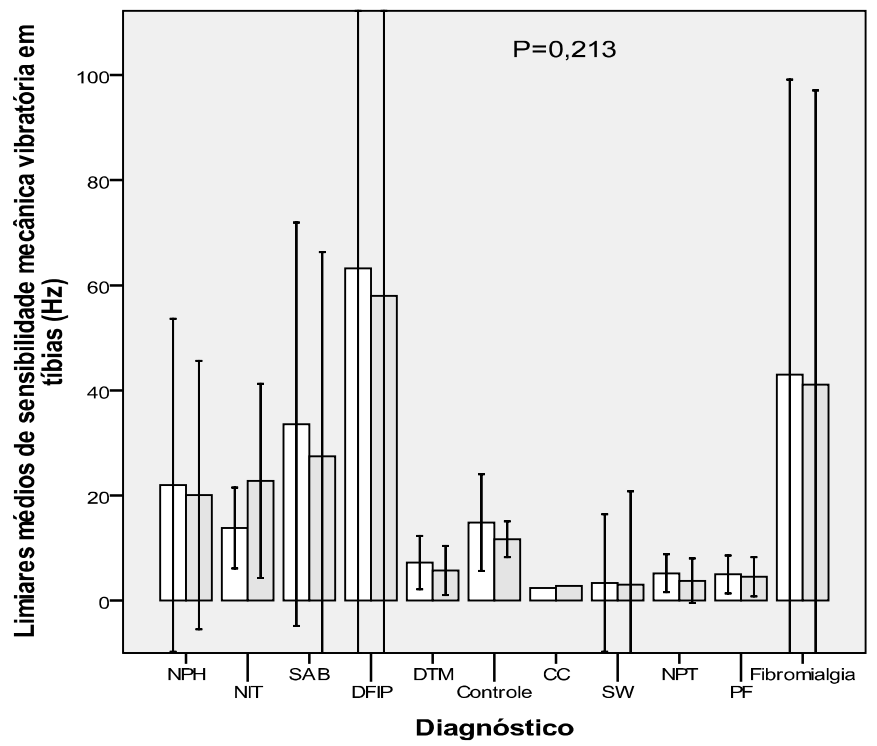

$$
\text { Lado }
$$

$\square$ direito

$\square$ esquerdo

$\left(^{*}\right) \quad$ Teste ANOVA 1 fator, PostHoc: teste de Tukey. As barras correspondem ao intervalo de confiança $95 \%$

${ }^{* *}$ NIT: Neuralgia Idiopática do Trigêmeo; DTM: Disfunção Temporomandibular; SAB: Síndrome da Ardência Bucal; DFIP: Dor Facial Idiopática Persistente; NPH: Neuralgia Pós-herpética; NPT: Neuropatia Pós-traumática; CC: Cefaléia Cervicogênica; PF: Paralisia facial; SW: Síndrome de Wallemberg. 
Figura 44 - Avaliação sensitiva quantitativa mecânica elétrica: comparação entre os lados de acordo com o local (mãos ou tíbia) $(\mathrm{N}=123)$
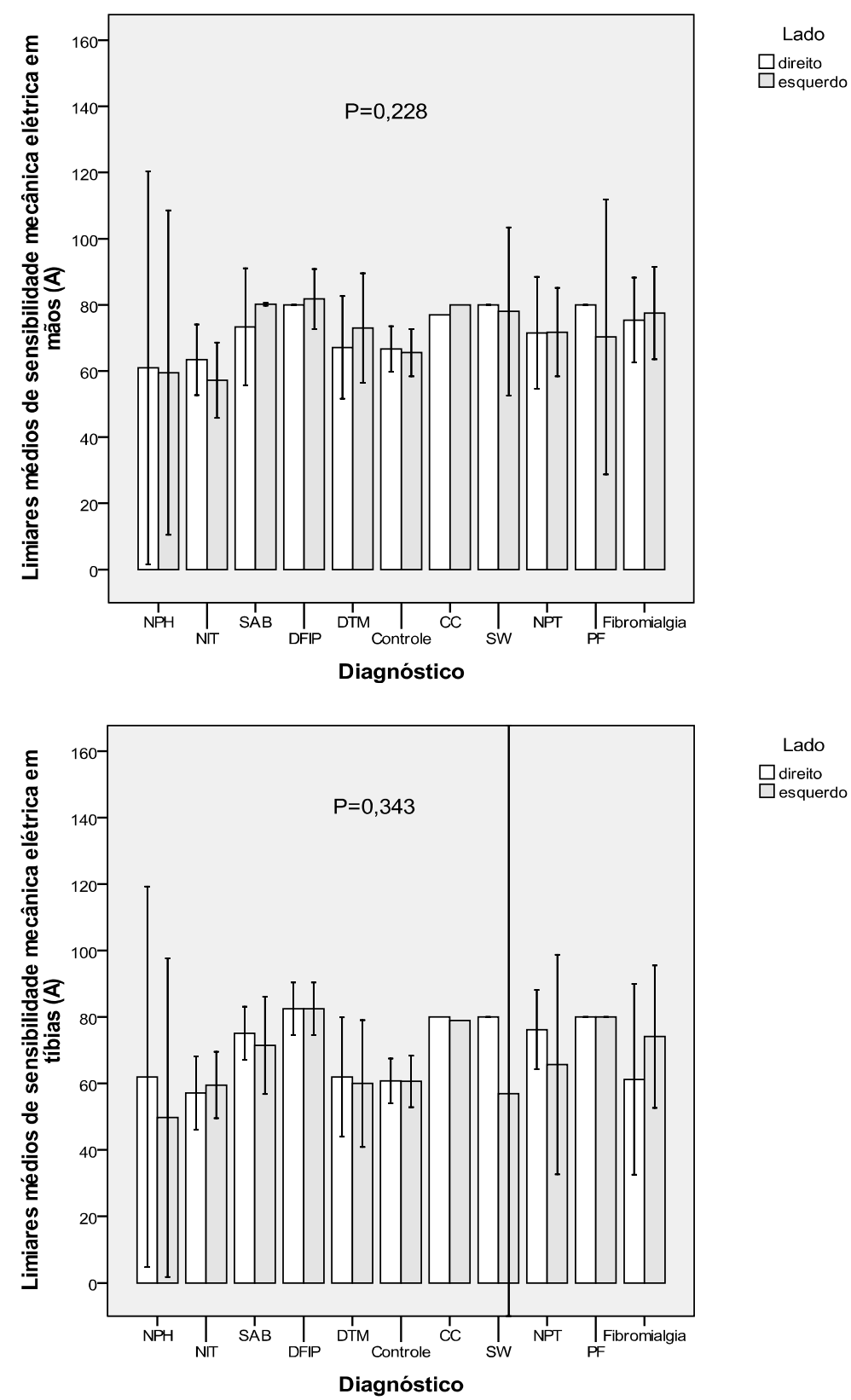

$\square$ direito
$\square$ esquerdo

$\left({ }^{*}\right) \quad$ Teste ANOVA 1 fator, PostHoc: teste de Tukey. As barras correspondem ao intervalo de confiança $95 \%$

$\left({ }^{* *}\right) \quad$ NIT: Neuralgia Idiopática do Trigêmeo; DTM: Disfunção Temporomandibular; SAB: Síndrome da Ardência Bucal; DFIP: Dor Facial Idiopática Persistente; NPH: Neuralgia Pós-herpética; NPT: Neuropatia Pós-traumática; CC: Cefaléia Cervicogênica; PF: Paralisia facial; SW: Síndrome de Wallemberg. 
Figura 45 - $\quad$ Avaliação sensitiva quantitativa dolorosa de profundidade: comparação entre os lados de acordo com o local (mãos ou tíbia) $(\mathrm{N}=123)$
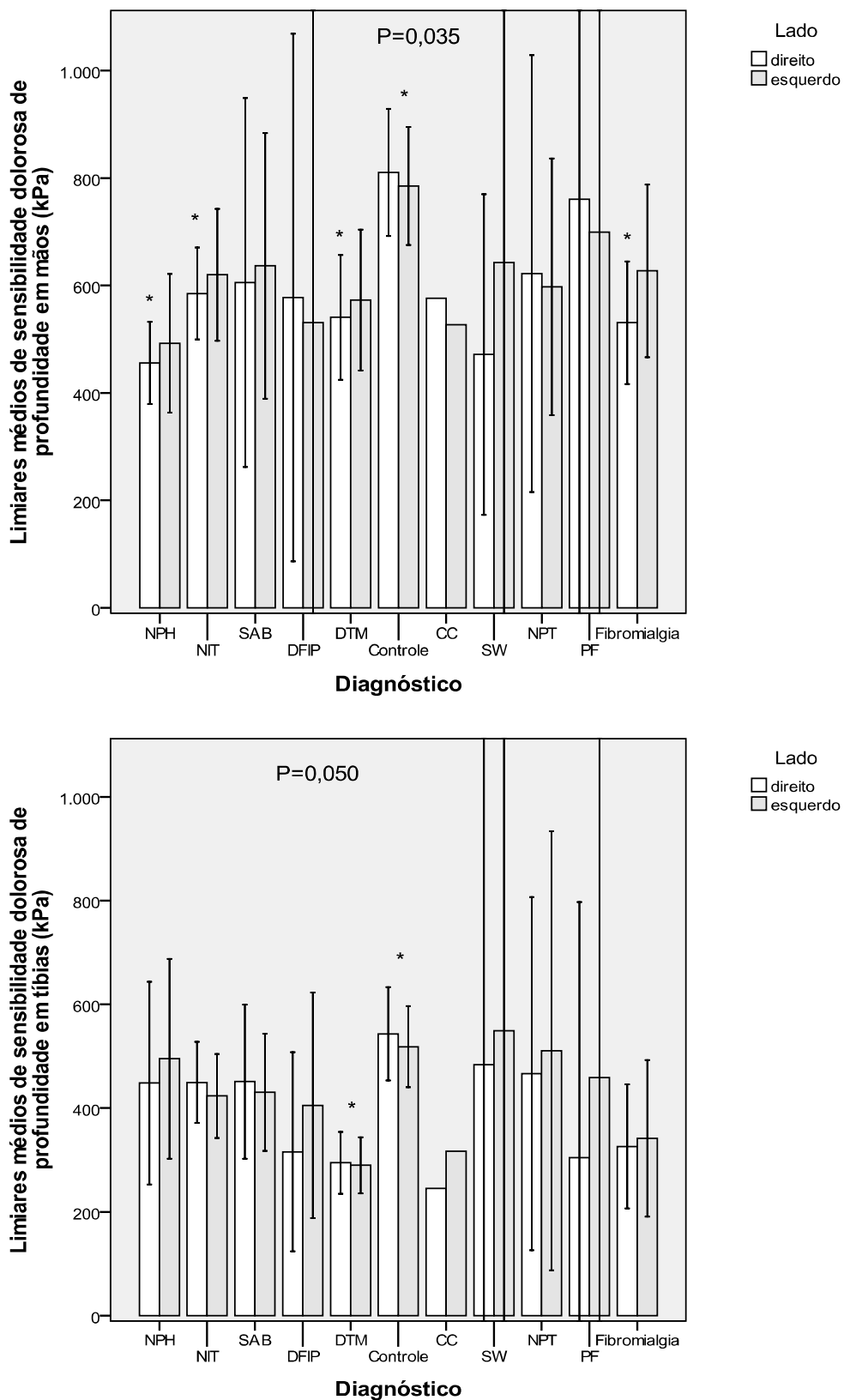

$\square$ direito

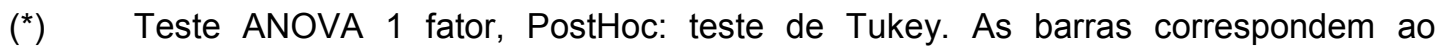
intervalo de confiança $95 \%$

$\left({ }^{* *}\right) \quad$ NIT: Neuralgia Idiopática do Trigêmeo; DTM: Disfunção Temporomandibular; SAB: Síndrome da Ardência Bucal; DFIP: Dor Facial Idiopática Persistente; NPH: Neuralgia Pós-herpética; NPT: Neuropatia Pós-traumática; CC: Cefaléia Cervicogênica; PF: Paralisia facial; SW: Síndrome de Wallemberg. 
Figura 46 - Avaliação sensitiva quantitativa dolorosa de superfície: comparação entre os lados de acordo com o local (mãos ou tíbia) $(\mathrm{N}=123)$

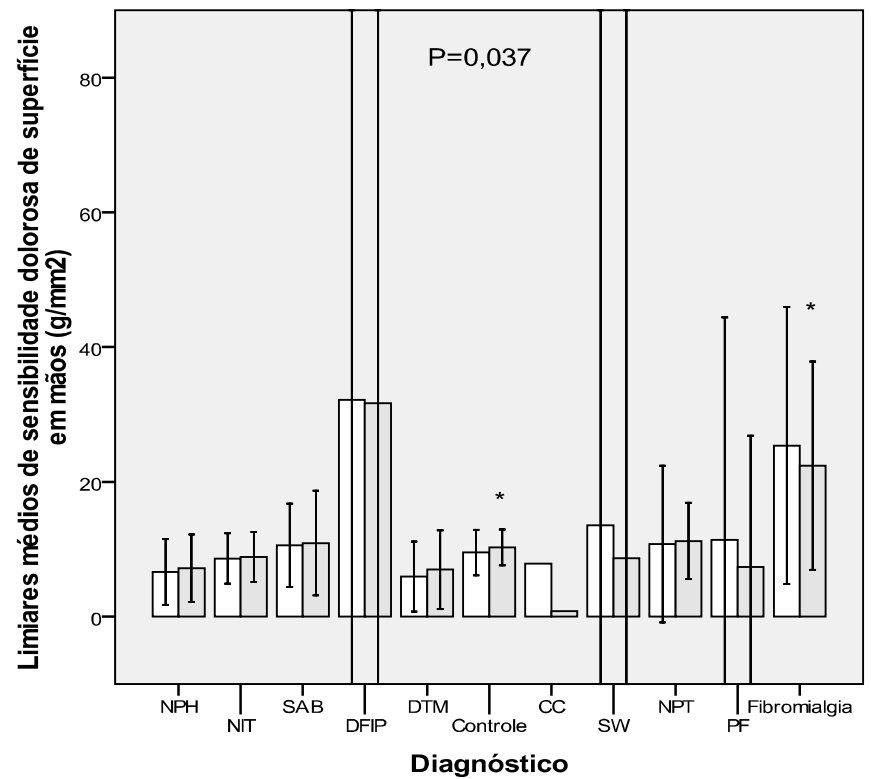

$$
\begin{gathered}
\text { Lado } \\
\square \text { direito } \\
\square \text { esquerdo }
\end{gathered}
$$
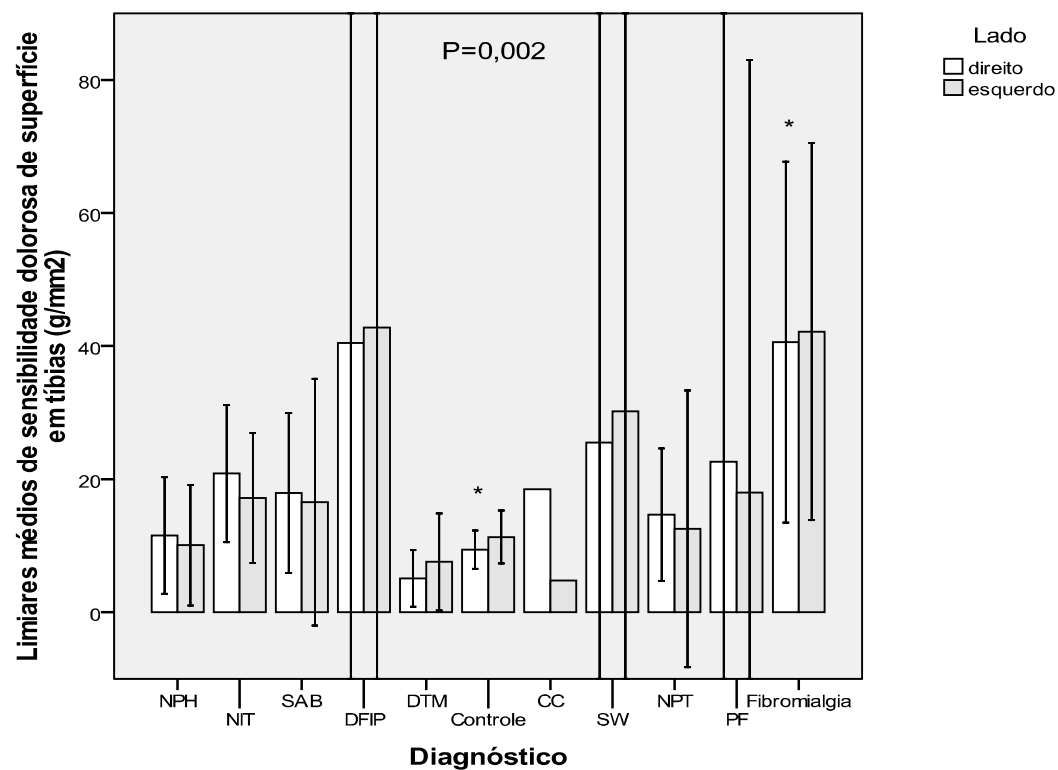

$\square$ direito

$\left(^{*}\right) \quad$ Teste ANOVA 1 fator, PostHoc: teste de Tukey. As barras correspondem ao intervalo de confiança $95 \%$

$\left({ }^{* *}\right) \quad$ NIT: Neuralgia Idiopática do Trigêmeo; DTM: Disfunção Temporomandibular; SAB: Síndrome da Ardência Bucal; DFIP: Dor Facial Idiopática Persistente; NPH: Neuralgia Pós-herpética; NPT: Neuropatia Pós-traumática; CC: Cefaleia Cervicogênica; PF: Paralisia facial; SW: Síndrome de Wallemberg.

Análises de correlação entre as variáveis de sensibilidade foram realizadas e foram positivas entre os limiares térmicos de frio e calor 
$(p<0,001)$, calor e táctil $(p=0,036)$, térmicos (frio e calor) e mecânico vibratório $(p<0,001)$, mecânico elétrico e térmicos (frio e calor) $(p=0,013$ e $p=0,001$, respectivamente), dolorosos de superfície e térmicos (frio e calor) $(p=0,001$ e $p<0,001$, respectivamente), calor e dolorosos de profundidade $(p=0,011)$ e calor e limiares gustativos $(p=0,041)$. Os limiares mecânicos tácteis foram maiores, quanto maiores os limiares mecânicos elétricos $(p=0,018)$ e os limiares dolorosos de superfície $(p<0,001)$; os limiares mecânicos vibratórios se correlacionaram positivamente com limiares mecânicos elétricos $(p=0,004)$, com limiares dolorosos de superfície $(p<0,001)$ e com limiares gustativos $(p<0,001)$, assim como, houve correlação entre limiares elétricos e limiares dolorosos de profundidade $(p=0,049)$, de superfície $(p<0,001)$ e gustativos $(p=0,017)$. Quanto maiores os limiares dolorosos de superfície, maiores os limiares gustativos $(p=0,006)$. Dormência subjetiva e limiares tácteis, também, se correlacionaram positivamente $(p=0,025)$.

As mulheres apresentaram menores limiares térmicos de calor $(p<0,001)$ e menores limiares dolorosos de profundidade $(p<0,001)$; houve correlação positiva entre: calor e altura $(p=0,023)$, calor, frio e idade $(p<0,001)$, limiar táctil com intensidade de dormência $(p=0,025)$ e disestesia $(p=0,039)$, limiar vibratório com intensidade de dor $(p=0,032)$ e com intensidade de incômodo de mastigação $(p=0,023)$, limiar elétrico com incômodo de mastigação $(p=0,029)$, limiares dolorosos de profundidade com altura $(p=0,035)$, duração da dor $(p=0,005)$, intensidade da dor $(p=0,001)$ e intensidade de incômodo de mastigação $(p=0,035)$; por fim, algiometria de 
superfície esteve correlacionada positivamente com intensidade da dor $(p=0,024)$.

Não houve associações entre raça e estado civil e quaisquer variáveis. Doentes com dor bilateral apresentaram maiores limiares dolorosos de profundidade $(p=0,005)$, maior idade $(p=0,005)$, menor duração da dor $(p<0,001)$, menor intensidade de dor $(p<0,001)$, menor incômodo de mastigação $(p<0,001)$ e menos dormência e disestesia $(p<0,001)$.

\subsection{Características de dor orofacial da amostra $(\mathrm{N}=123)$}

As características de dor orofacial, mastigação e fatores associados estão apresentados nas Tabelas de 8 a 12. Houve diferenças entre os grupos com relação à queixa principal $(p<0,001)$, períodos de dor $(p=0,005)$, descritores espontâneos $(p=0,002)$, intensidade de dor $(p=0,007)$, fatores de piora $(p<0,001)$ e de melhora $(p<0,001)$ (Tabelas 8 e 9). Dor generalizada foi mais frequente nos doentes com fibromialgia $(p=0,008)$ (Tabela 10). As morbidades associadas podem ser observadas na Tabela 11. Os doentes com DTM apresentaram mais incômodos de mastigação $(p=0,001)$ e o lado de mastigação foi mais anterior nos doentes com DFIP $(p=0,001)$ (Tabela 12). A qualidade da mastigação foi melhor nos controles $(p<0,001)($ Tabela 13). 
Tabela 8 - $\quad$ Características de dor orofacial da amostra (queixa principal, períodos de dor, intensidade e duração): comparação entre os diagnósticos $(\mathrm{N}=123)$.

\begin{tabular}{|c|c|c|c|c|}
\hline & Queixa principal (\%) & Períodos de dor (\%) & $\begin{array}{l}\text { Duração da } \\
\text { dor em anos } \\
\text { (média士DP) }\end{array}$ & $\begin{array}{l}\text { Intensidade } \\
\text { da dor } \\
\text { (EVA) }{ }^{* * *} \\
\text { (média } \pm D P \text { ) }\end{array}$ \\
\hline NIT $^{* *}$ & $\begin{array}{l}\text { Choque na face: } 20 \\
(69,0) \\
\text { Dor intraoral: } 6(20,7) \\
\text { Dormência: } 3(10,3)\end{array}$ & $\begin{array}{l}\text { Diária: } 25(86,2) \\
2-3 \text { x por semana: } 4(13,8)\end{array}$ & $\begin{array}{c}5,6 \pm 4,9 \\
(1-20)\end{array}$ & $\begin{array}{l}8,39 \pm 2,59 \\
(4-10)\end{array}$ \\
\hline DTM & $\begin{array}{l}\text { Dor em face: } 7(62,6) \\
\text { Dor em movimentos } \\
\text { mandibulares: } 4(36,4)\end{array}$ & $\begin{array}{l}\text { Diária: } 5(45,5) \\
2-3 \text { x por semana: } 5(45,5) \\
\text { Mensal: } 1(9,0)\end{array}$ & $\begin{array}{l}9,07 \pm 8,32 \\
(1-25)\end{array}$ & $\begin{array}{c}7,83 \pm 1,82 \\
(5-10)\end{array}$ \\
\hline SAB & Dor intraoral: $8(100,0)$ & Diária: $8(100,0)$ & $\begin{array}{l}4,29 \pm 3,90 \\
(1-10)\end{array}$ & $\begin{array}{c}6,75 \pm 3,17 \\
(1-10)\end{array}$ \\
\hline DFIP & Dor em face: $8(100,0)$ & Diária: $8(100,0)$ & $\begin{array}{l}5,14 \pm 1,94 \\
\quad(1-13)\end{array}$ & $\begin{array}{l}8,63 \pm 1,63 \\
(5-10)\end{array}$ \\
\hline Fibromialgia & $\begin{array}{l}\text { Dor em face: } 7(87,5) \\
\text { Dor e dormência: } 1 \\
(12,5)\end{array}$ & $\begin{array}{l}\text { Diária: } 7(87,5) \\
2-3 \text { x por semana: } 1(12,5)\end{array}$ & $\begin{array}{l}5,25 \pm 2,91 \\
(2-11)\end{array}$ & $\begin{array}{c}9,00 \pm 1,71 \\
(5-10)\end{array}$ \\
\hline NPH & $\begin{array}{l}\text { Dor em face: } 4(66,7) \text {, } \\
\text { Coceira: } 1(16.7) \\
\text { Dor de dente: } 1(16,7)\end{array}$ & $\begin{array}{l}\text { Diária: } 4(66,7) \\
\text { Semanal: } 1(16.7) \\
\text { Quinzenal: } 1(16,7)\end{array}$ & $\begin{array}{l}7,55 \pm 7,50 \\
(1-23)\end{array}$ & $8,50 \pm 2,39(4-10)$ \\
\hline NPT & $\begin{array}{l}\text { Dor em face: } 2(40,0) \\
\text { Dor ao mastigar } 1(20,0) \\
\text { Dormência: } 1(20,0) \\
\text { Dor intraoral: } 1(20,0)\end{array}$ & $\begin{array}{l}\text { Diária: } 4(80,0) \\
2-3 \text { x por semana: } 1(20,0)\end{array}$ & $\begin{array}{l}11,75 \pm 11,77 \\
(1-30)\end{array}$ & $\begin{array}{l}4,80 \pm 4,07 \\
(1-10)\end{array}$ \\
\hline CC & $\begin{array}{l}\text { Dor em face: } 1(50,0) \\
\text { Dor em cervical: } 1(50,0)\end{array}$ & Diária: $2(100,0)$ & $\begin{array}{l}3,00 \pm 0,00 \\
\text { (3) }\end{array}$ & $\begin{array}{l}4,50 \pm 1,73 \\
(3-6)\end{array}$ \\
\hline PF & Dor em face: $3(100,0)$ & Diária: $3(100,0)$ & $\begin{array}{l}2,83 \pm 1,86 \\
(1-4)\end{array}$ & $\begin{array}{l}6,67 \pm 5,16 \\
(1-10)\end{array}$ \\
\hline sw & $\begin{array}{l}\text { Dor e dormência: } 1 \\
(50,0) \\
\text { Dormência: } 1(50,0)\end{array}$ & Diária: $2(100,0)$ & $\begin{array}{l}4,50 \pm 1,73 \\
(3-6)\end{array}$ & $\begin{array}{c}9,00 \pm 1,15 \\
(8-10)\end{array}$ \\
\hline Controle & - & - & - & - \\
\hline TOTAL & $\begin{array}{l}\text { Dor na face: } 34(27,6) \\
\text { Choque na face: } 20 \\
(16,3) \\
\text { Dor intraoral } 15(12,2) \\
\text { Dormência: } 7(5,7) \\
\text { Dor ao mastigar: } 1(0,8) \\
\text { Coceira: } 1(0,8) \\
\text { Dor cervical: } 1(0,8) \\
\text { Dor de dente: } 1(0,8)\end{array}$ & $\begin{array}{l}\text { Diária: } 68(55,3) \\
2-3 \text { x por semana } 11(8,9) \\
\text { Semanal: } 1(0,8) \\
\text { Quinzenal: } 1(0,8) \\
\text { Mensal: } 1(0,8)\end{array}$ & $\begin{array}{l}4,03 \pm 5,56 \\
(1-30)\end{array}$ & $\begin{array}{l}5,26 \pm 4,39 \\
\quad(1-10)\end{array}$ \\
\hline$p^{*}$ & $<0,001^{* * * *}$ & 0,005 & 0,493 & 0,007 \\
\hline
\end{tabular}

$\left(^{*}\right) \quad$ Testes Qui-quadrado de Pearson e teste T de Student.

$\left({ }^{* *}\right) \quad$ NIT: Neuralgia Idiopática do Trigêmeo; DTM: Disfunção Temporomandibular; SAB: Síndrome da Ardência Bucal; DFIP: Dor Facial Idiopática Persistente; NPH: Neuralgia Pós-herpética; NPT: Neuropatia Pós-traumática; CC: Cefaleia Cervicogênica; PF: Paralisia facial; SW: Síndrome de Wallemberg.

$\left({ }^{* * *}\right) \quad$ EVA: Escala visual analógica.

${ }^{* * * *}$ Teste $Z$ indicou diversas diferenças entre os grupos. 
Tabela 9 - Características de dor orofacial da amostra (descritores espontâneos, fatores de melhora e de piora): comparação entre os diagnósticos $(\mathrm{N}=123)$.

\begin{tabular}{|c|c|c|c|}
\hline & $\begin{array}{c}\text { Descritores } \\
\text { espontâneos (\%) }\end{array}$ & Fatores de piora (\%) & Fatores de Melhora (\%) \\
\hline \multirow{5}{*}{$\mathrm{NIT}^{* *}$} & Choque: $24(82,8)$ & Estresse emocional: $12(41,4)$ & Medicamentos: $13(44,8)$ \\
\hline & Pontada: $2(6,9)$ & Tempo frio: $9(31,0)$ & Repouso: $3(10,3)$ \\
\hline & Agulhada: $1(3,4)$ & Atividades mandibulares: 10 (34.5) & Trabalhar: $2(6,9)$ \\
\hline & Dolorida: $1(3,4)$ & Alimentos ácidos: $1(3,4)$ & Fé: $1(3,4)$ \\
\hline & Latejante: $9(81,8)$ & Atividades mandibulares: $5(45,5)$ & Medicamentos $6(54,5)$ \\
\hline \multirow{2}{*}{ DTM } & Peso: $4(26,4)$ & Estresse emocional: $1(9,0)$ & Massagem: $2(18,2)$ \\
\hline & $\begin{array}{l}\text { Pontada: } 3(27,3) \\
\text { Queimação: } 1(9,0)\end{array}$ & Tempo frio: $1(9,0)$ & Repouso: $1(9,0)$ \\
\hline \multirow{3}{*}{ SAB } & Queimação: $6(75,0)$ & Alimentar-se: $3(37,5)$ & Medicamentos: $2(25,0)$ \\
\hline & Pontada: $2(25,0)$ & Estresse emocional: $2(25,0)$ & Balas e chicletes: $1(12,5)$ \\
\hline & Latejante: $6(75,0)$ & Estresse emocional: $3(37,5)$ & Medicamentos: $5(62,5)$ \\
\hline \multirow{4}{*}{ DFIP } & Peso: $4(50,0)$ & Tempo frio: $2(25,0)$ & Compressa quente: $1(12,5)$ \\
\hline & $\begin{array}{l}\text { Pontada: } 2(25,0) \\
\text { Choque: } 1(12,5)\end{array}$ & Atividades mandibulares: $4(50,0)$ & Repouso: $1(12,5)$ \\
\hline & Queimação: $5(62,5)$ & Atividades em geral: $7(87,5)$ & Medicamentos: $5(62,5)$ \\
\hline & Latejante: $4(50,0)$ & Tempo frio e estresse emocional: 1 & Repouso: $3(37,5)$ \\
\hline \multirow{4}{*}{ Fibromialgia } & Peso: $4(50,0)$ & $(12,5)$ & Massagem: $1(12,5)$ \\
\hline & $\begin{array}{l}\text { Pontada: } 4(50,0) \\
\text { Choque: } 3(37,5)\end{array}$ & & \\
\hline & Cansada: $1(12,5)$ & & \\
\hline & Queimação: $3(50,0)$ & Tempo frio: $1(16,7)$ & Medicamentos: $4(66,7)$ \\
\hline \multirow[t]{3}{*}{ NPH } & $\begin{array}{l}\text { Choque: } 2(33,3) \\
\text { Coceira: } 1(16,7)\end{array}$ & Alimentos condimentados: $1(16,7)$ & Compressa fria: $1(16,7)$ \\
\hline & Choque: $3(60,0)$ & Atividades mandibulares: $2(40,0)$ & Repouso: $2(40,0)$ \\
\hline & Pontada: $3(60,0)$ & Barulho: $1(20,0)$ & Medicamentos e fisioterapia: 1 \\
\hline \multirow{3}{*}{ NPT } & Queimação: $1(20,0)$ & Estresse emocional: $1(20,0)$ & $(20,0)$ \\
\hline & & & \\
\hline & Peso: $1(20,0)$ & & \\
\hline \multirow{2}{*}{ CC } & Queimação: $1(50,0)$ & Atividades mandibulares: $2(100,0)$ & Massagem: $1(50,0)$ \\
\hline & Latejante: $1(50,0)$ & & Repouso: $1(50,0)$ \\
\hline \multirow{2}{*}{ PF } & Queimação: $2(66,7)$ & Tempo frio: $1(33,3)$ & Medicamentos: $3(100,0)$ \\
\hline & Choque: $1(33,3)$ & Estresse emocional: $1(3,3)$ & \\
\hline sw & Queimação: $2(100,0)$ & Tempo frio: $1(50,0)$ & Massagem: $1(50,0)$ \\
\hline \multirow[t]{5}{*}{ Controle } & - & - & - \\
\hline & Choque: $34(27,6)$ & Atividades mandibulares: $22(17,9)$ & Medicamentos: $40(32,5)$ \\
\hline & Queimação: $21(17,1)$ & Estresse emocional: $21(17,1)$ & Repouso: $11(8,9)$ \\
\hline & Latejante: $21(17,1)$ & Tempo frio: $16(13,0)$ & Massagem: $5(4,1)$ \\
\hline & Pontada: $16(13,0)$ & Atividades gerais: $7(5,7)$ & Trabalhar: $2(1,6)$ \\
\hline \multirow{6}{*}{ TOTAL } & Peso: $13(10,6)$ & Alimentos: $2(1,6)$ & Fisioterapia: $1(0,8)$ \\
\hline & Cansada: $1(0,8)$ & Barulho: $1(0,8)$ & Compressa fria: $1(0,8)$ \\
\hline & Coceira: $1(0,8)$ & Movimento da cabeça: $1(0,8)$ & Compressa quente: $1(0,8)$ \\
\hline & Dormente: $1(0,8)$ & & Fé: $1(0,8)$ \\
\hline & Agulhada: $1(0,8)$ & & Balas/chicletes: $1(0,8)$ \\
\hline & Dolorida: $1(0,8)$ & & \\
\hline $\mathbf{p}^{*}$ & 0,002 & $<0,001$ & $<0,001^{* * *}$ \\
\hline
\end{tabular}

$\left(^{*}\right) \quad$ Testes Qui-quadrado de Pearson e teste T de Student.

$\left({ }^{* *}\right) \quad$ NIT: Neuralgia Idiopática do Trigêmeo; DTM: Disfunção Temporomandibular; SAB: Síndrome da Ardência Bucal; DFIP: Dor Facial Idiopática Persistente; NPH: Neuralgia Pós-herpética; NPT: Neuropatia Pós-traumática; CC: Cefaleia Cervicogênica; PF: Paralisia facial; SW: Síndrome de Wallemberg.

$\left({ }^{\star * *}\right) \quad$ Teste $Z$ indicou diversas diferenças entre os grupos. 
Tabela 10 - Queixas de cefaleia, dor generalizada e qualidade do sono: comparação entre os diagnósticos $(\mathrm{N}=123)$.

\begin{tabular}{|c|c|c|c|}
\hline & Cefaleia (\%) & Dor generalizada (\%) & Qualidade do sono (\%) \\
\hline NIT** & $13(44,8)$ & $13(44,8)$ & 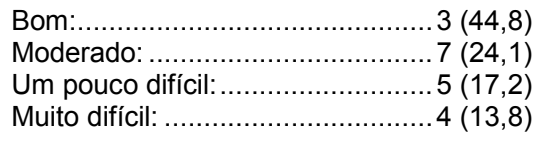 \\
\hline DTM & $10(90,9)$ & $8(72,7)$ & 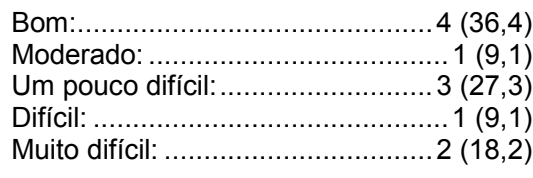 \\
\hline SAB & $7(87,5)$ & $8(100,0)$ & 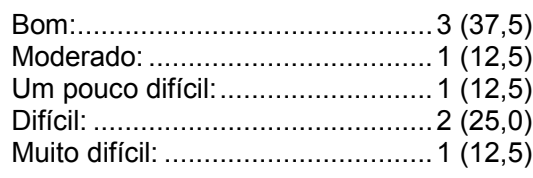 \\
\hline DFIP & $5(62,5)$ & $6(75,0)$ & 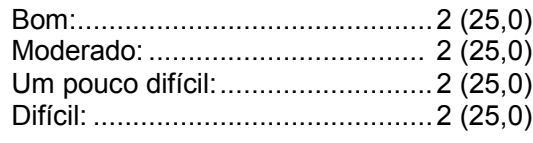 \\
\hline Fibromialgia & $8(100,0)$ & $8(100,0)$ & 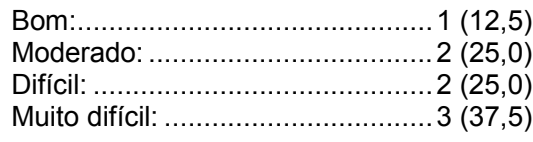 \\
\hline NPH & $2(33,3)$ & $3(50,0)$ & 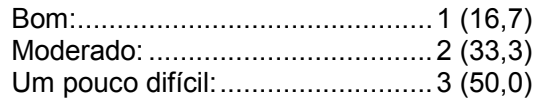 \\
\hline NPT & $4(80,0)$ & $1(20,0)$ & 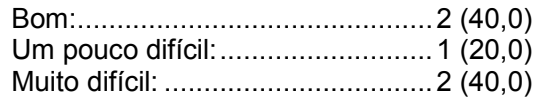 \\
\hline CC & $1(50,0)$ & $1(50,0)$ & $\begin{array}{l}\text { Bom: } \\
\text { Um pouco difícil: }\end{array}$ \\
\hline PF & $2(66,7)$ & $3(100,0)$ & 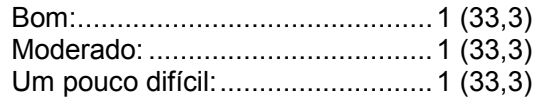 \\
\hline sw & $1(50,0)$ & $2(100,0)$ & $\begin{array}{l}\text { Bom: } \\
\text { Um pouco difícil:....................................... } 1(50,0)\end{array}$ \\
\hline Controle & - & - & 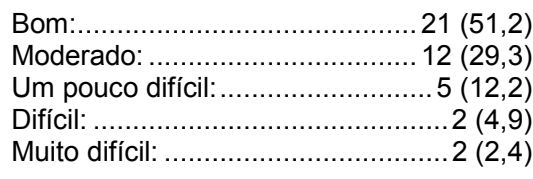 \\
\hline TOTAL & $53(43,1)$ & $53(43,1)$ & 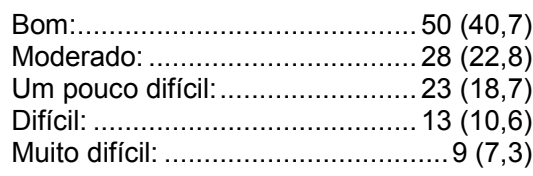 \\
\hline $\mathbf{p}^{*}$ & 0,290 & $0,008^{\star * *}$ & 0,602 \\
\hline
\end{tabular}

$\left({ }^{*}\right) \quad$ Testes Qui-quadrado de Pearson.

$\left({ }^{* *}\right) \quad$ NIT: Neuralgia Idiopática do Trigêmeo; DTM: Disfunção Temporomandibular; SAB: Síndrome da Ardência Bucal; DFIP: Dor Facial Idiopática Persistente; NPH: Neuralgia Pós-herpética; NPT: Neuropatia Pós-traumática; CC: Cefaleia Cervicogênica; PF: Paralisia facial; SW: Síndrome de Wallemberg; AR: artrite reumatóide:;HAS: hipertensão arterial sistêmica .

${ }^{(* * *}$ Teste $\mathbf{Z}$ indicou maior prevalência de dor generalizada em fibromialgia e SAB. 
Tabela 11 - Morbidades associadas: comparação entre os diagnósticos $(\mathrm{N}=123)$.

\begin{tabular}{|c|c|c|}
\hline & \multicolumn{2}{|c|}{ Morbidades associadas (\%) ${ }^{* *}$} \\
\hline $\mathrm{NIT}^{* *}$ & 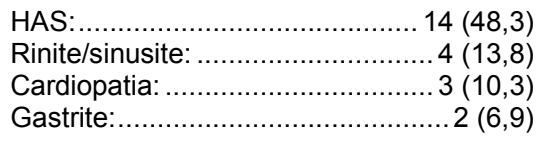 & 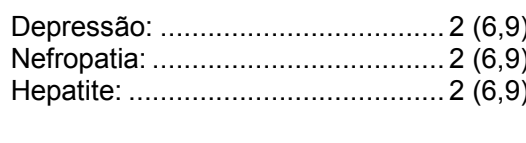 \\
\hline DTM & $\begin{array}{l}\text { Rinite/sinusite: } \\
\text { Gastrite: }\end{array}$ & $\begin{array}{l}\text { Cardiopatia: } \\
\text { AR: }\end{array}$ \\
\hline SAB & $\begin{array}{l}\text { HAS: } \\
\text { Depressão: }\end{array}$ & \\
\hline DFIP & $\begin{array}{l}\text { Depressão: } \\
\text { Gastrite: } \\
\text { HAS: }\end{array}$ & 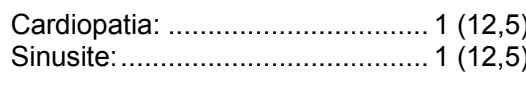 \\
\hline Fibromialgia & 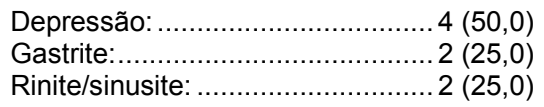 & \\
\hline NPH & $\begin{array}{l}\text { AR: } \\
\text { HAS: }\end{array}$ & Cardiopatia: ....... \\
\hline NPT & 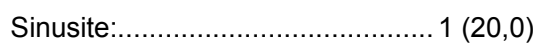 & \\
\hline CC & HAS: & \\
\hline PF & $\begin{array}{l}\text { Depressão: } \\
\text { HAS: }\end{array}$ & $\begin{array}{l}\text { Rinite: } \\
\text { AR: }\end{array}$ \\
\hline sw & $\begin{array}{l}\text { Cardiopatia: } \\
\text { Sinusite: }\end{array}$ & \\
\hline Controle & 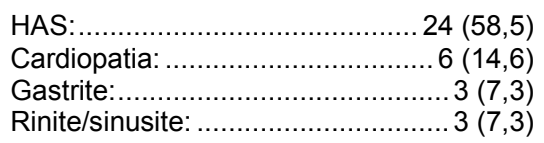 & 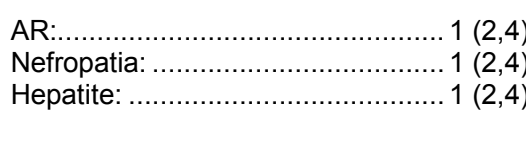 \\
\hline TOTAL & 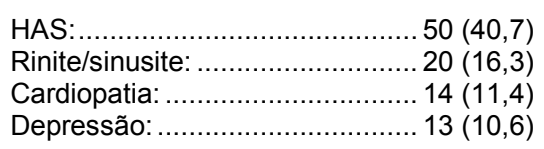 & 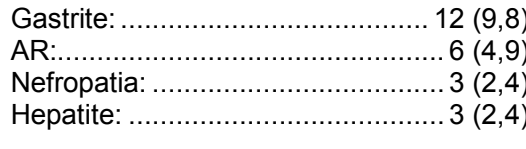 \\
\hline$p^{*}$ & & \\
\hline
\end{tabular}

$\left(^{*}\right) \quad$ Testes Qui-quadrado de Pearson.

$\left({ }^{* *}\right) \quad$ NIT: Neuralgia Idiopática do Trigêmeo; DTM: Disfunção Temporomandibular; SAB: Síndrome da Ardência Bucal; DFIP: Dor Facial Idiopática Persistente; NPH: Neuralgia Pós-herpética; NPT: Neuropatia Pós-traumática; CC: Cefaleia Cervicogênica; PF: Paralisia facial; SW: Síndrome de Wallemberg; AR: artrite reumatóide HAS: hipertensão arterial sistêmica . 
Tabela 12 - Características mandibulares e de mastigação (incômodo e lateralidade): comparação entre os diagnósticos ( $\mathrm{N}=123)$.

\begin{tabular}{|c|c|c|c|}
\hline & $\begin{array}{l}\text { Incômodo de } \\
\text { mastigação (\%) }\end{array}$ & $\begin{array}{l}\text { Intensidade do } \\
\text { incômodo } \\
\text { (média } \pm D P \text { ) }\end{array}$ & Lateralidade da mastigação (\%) \\
\hline NIT & $16(55,2)$ & $3,83 \pm 4,07(0-10)$ & 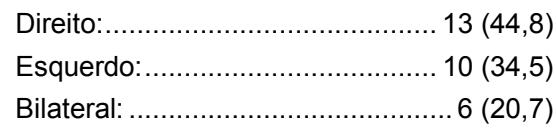 \\
\hline DTM & $8(72,7)$ & $5,55 \pm 3,83(0-10)$ & 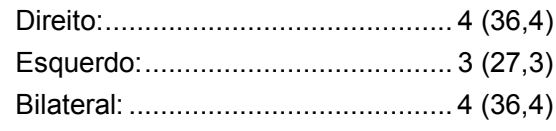 \\
\hline SAB & $5(62,5)$ & $5,00 \pm 4,66(0-10)$ & 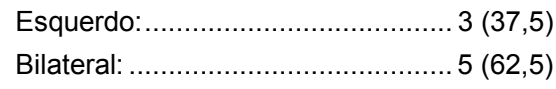 \\
\hline DFIP & $4(50,0)$ & $6,25 \pm 4,43(0-10)$ & 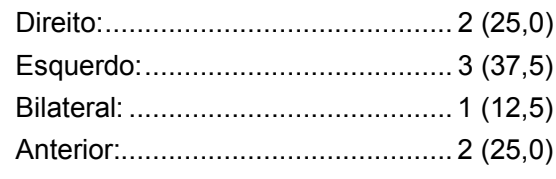 \\
\hline Fibromialgia & $5(62,5)$ & $4,63 \pm 4,37(0-10)$ & 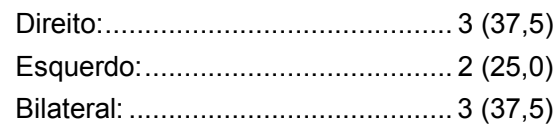 \\
\hline NPH & $2(33,3)$ & $2,50 \pm 4,18(0-10)$ & 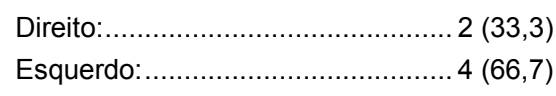 \\
\hline NPT & $4(80,0)$ & $5,80 \pm 3,96(0-10)$ & 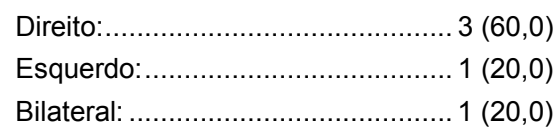 \\
\hline $\mathrm{CC}$ & $2(100,0)$ & $5,50 \pm 3,53(3-8)$ & $\begin{array}{l}\text { Direito: } \\
\text { Esquerdo: }\end{array}$ \\
\hline PF & $2(66,7)$ & $6,67 \pm 5,77(0-10)$ & 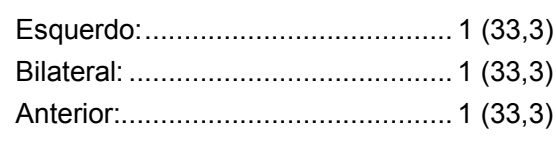 \\
\hline sw & - & - & 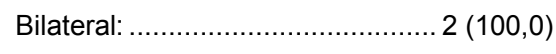 \\
\hline Controle & $6(14,6)$ & $0,66 \pm 1,80(0-6)$ & 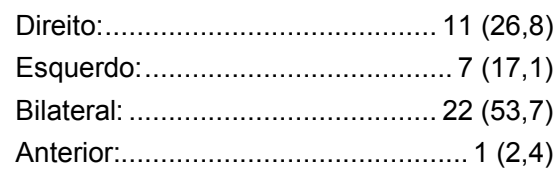 \\
\hline TOTAL & $54(43,9)$ & $3,26 \pm 3,20(0-10)$ & 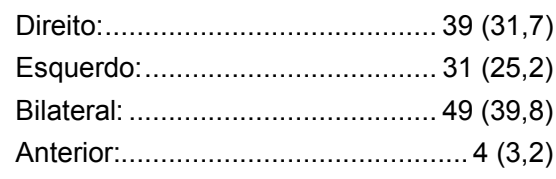 \\
\hline $\mathbf{p}^{*}$ & $0,001^{* * *}$ & $<0,001$ & 0,001 \\
\hline
\end{tabular}

${ }^{*}$ ) Testes Qui-quadrado de Pearson, exato de Fisher e teste T de Student.

$\left(^{* *}\right) \quad$ NIT: Neuralgia Idiopática do Trigêmeo; DTM: Disfunção Temporomandibular; SAB: Síndrome da Ardência Bucal; DFIP: Dor Facial Idiopática Persistente; NPH: Neuralgia Pós-herpética; NPT: Neuropatia Pós-traumática; CC: Cefaleia Cervicogênica; PF: Paralisia facial; SW: Síndrome de Wallemberg.

$\left.{ }^{(* *}\right) \quad$ Teste $Z$ indicou que o incômodo de mastigação foi maior nos doentes com DTM e o lado da mastigação foi mais anterior nos doentes com DFIP. 
Tabela 13 - Características mandibulares e de mastigação (qualidfade, abertura bucal e hábitos): comparação entre os diagnósticos $(\mathrm{N}=123)$

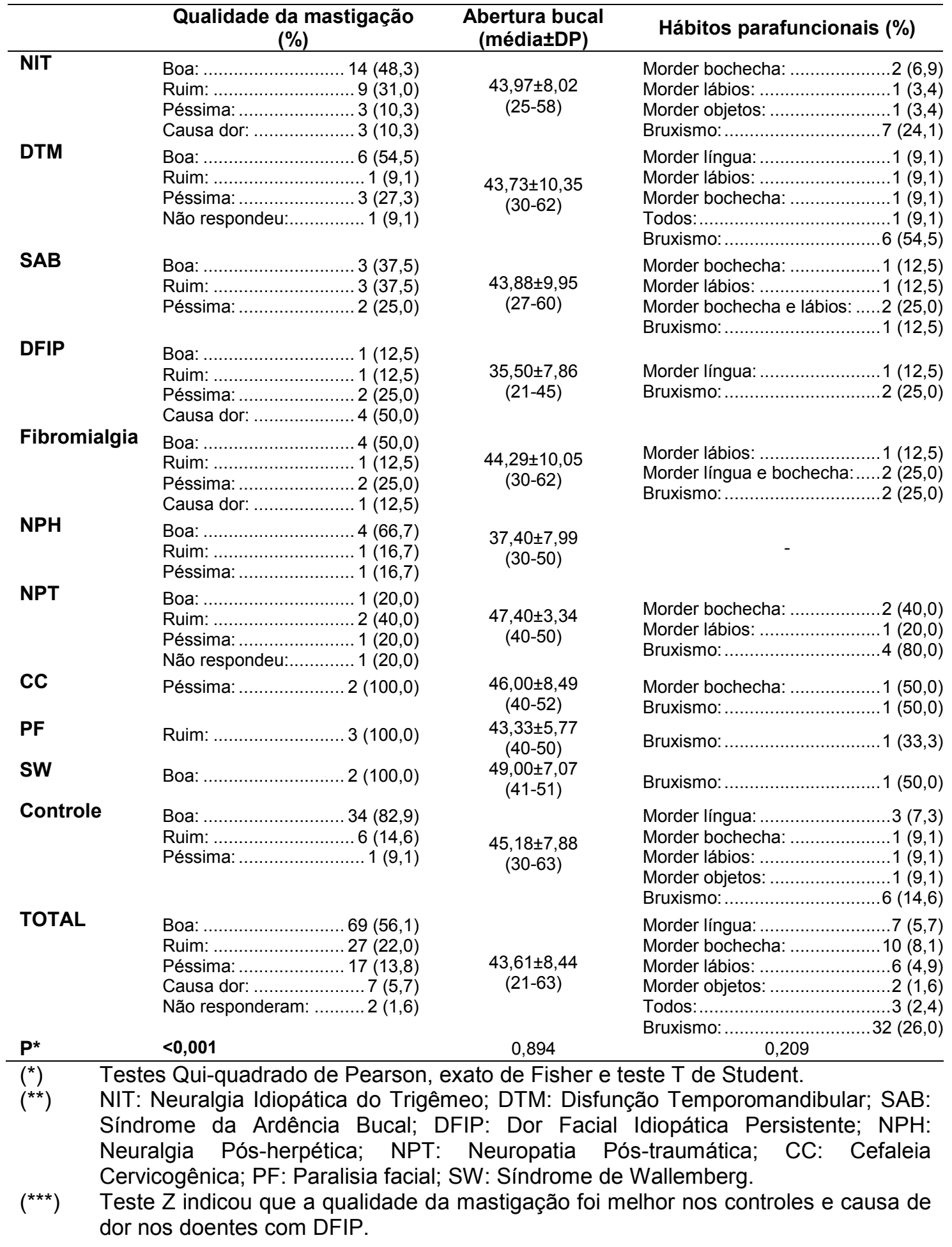

Dor ao acordar foi mais prevalente em fibromialgia $(p=0,001)$, cansaço facial e dores aos movimentos mandibulares foram mais frequentes 
em DTM ( $p<0,001$ e $p=0,009$ respectivamente) e queixas de mastigação foram menos prevalentes nos controles ( $p=0,001)$ (Tabelas 14 e 15). Doentes com SAB apresentaram mais ressecamento em mucosa oral $(p=0,014)$ e maior prevalência de língua fissurada $(p=0,003)$. Houve variações nas anormalidades em mucosa oral $(p=0,014)$ e dor à palpação facial foi mais comum nos doentes com DTM $(p<0,001)$ (Tabelas 16 e 17). 
Tabela 14 - Queixas mandibulares da amostra: comparação entre os diagnósticos $(\mathrm{N}=123)$.

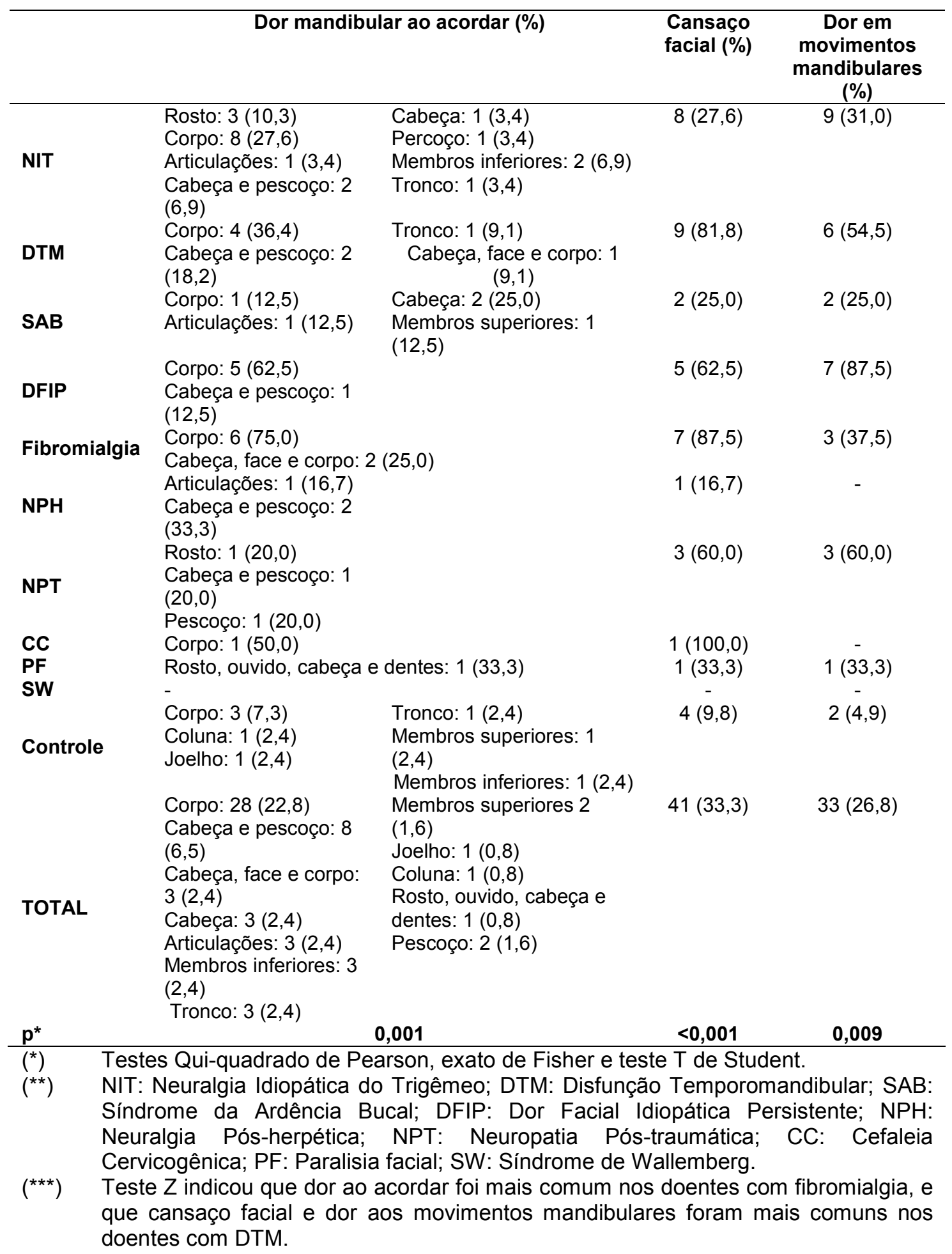


Tabela 15 - Queixas de mastigação da amostra: comparação entre os diagnósticos $(\mathrm{N}=123)$.

\begin{tabular}{|c|c|c|c|}
\hline \multirow{2}{*}{\multicolumn{2}{|c|}{ NIT }} & \multicolumn{2}{|c|}{ Queixas de mastigação (\%) } \\
\hline & & $\begin{array}{l}\text { Pela dor: } \\
\text { Dificuldade de mastigar: }\end{array}$ & $\begin{array}{l}\text { Outro: } \\
\text { Indefinido: }\end{array}$ \\
\hline \multicolumn{2}{|l|}{ DTM } & $\begin{array}{l}\text { Pela dor: } \\
\text { Dificuldade de mastigar:........... } 1(9,1)\end{array}$ & $\begin{array}{l}\text { Indefinido: } \\
\text { Prótese ruim: }\end{array}$ \\
\hline \multicolumn{2}{|l|}{ SAB } & Alimentos duros: ..................1 $1(12,5)$ & Pela dor: ............ $3(37,5)$ \\
\hline \multicolumn{2}{|l|}{ DFIP } & $\begin{array}{l}\text { Ausência de dentes: } \\
\text { Alimentos duros: } \ldots \ldots \ldots \ldots \ldots \ldots . . . . . . .1(12,5) \\
\end{array}$ & Pela dor: \\
\hline \multicolumn{2}{|c|}{ Fibromialgia } & 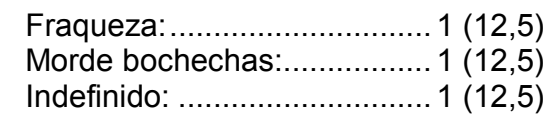 & $\begin{array}{l}\text { Pela dor: } \\
\text { Prótese ruim: } \ldots \ldots \ldots \ldots \ldots \ldots \ldots \ldots \ldots \ldots \ldots . . .11(12,5)\end{array}$ \\
\hline \multicolumn{2}{|l|}{ NPH } & Prótese ruim: & Outro: \\
\hline \multicolumn{2}{|l|}{ NPT } & $\begin{array}{l}\text { Dentes sensíveis: } \\
\text { Alimentos duros: } \ldots \ldots \ldots \ldots \ldots \ldots \ldots \ldots . . .1(20,0)\end{array}$ & $\ldots \ldots \ldots . .1(20,0)$ \\
\hline \multicolumn{2}{|l|}{ CC } & Prótese ruim: & Outro: \\
\hline \multicolumn{2}{|l|}{$\begin{array}{l}\text { PF } \\
\text { SW }\end{array}$} & Pela dor: & \\
\hline \multicolumn{2}{|l|}{ Controle } & $\begin{array}{l}\text { Dente fraturado: } \\
\text { Dentes sensíveis: } \ldots \ldots \ldots \ldots \ldots \ldots \ldots \ldots . .1(2,4) \\
\end{array}$ & $\begin{array}{l}\text { Pela dor :1 }(2,4) \\
\text { Prótese ruim: }\end{array}$ \\
\hline TOTAL & & 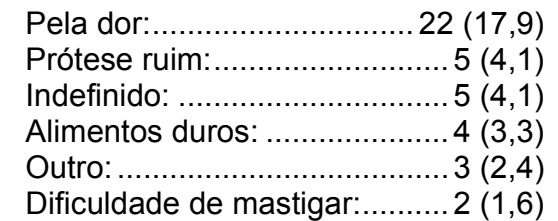 & 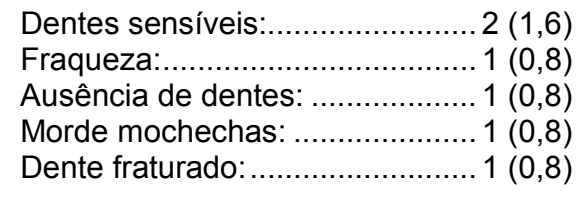 \\
\hline \multicolumn{2}{|l|}{$\mathbf{p}^{*}$} & \multicolumn{2}{|c|}{0,001} \\
\hline $\begin{array}{l}\left({ }^{*}\right) \\
(* *)\end{array}$ & $\begin{array}{l}\text { Teste } \\
\text { NIT: } \\
\text { Síndr } \\
\text { Neur } \\
\text { Cervi } \\
\text { Teste }\end{array}$ & $\begin{array}{l}\text { i-quadrado de Pearson, exato de Fi } \\
\text { algia Idiopática do Trigêmeo; DTM } \\
\text { da Ardência Bucal; DFIP: Dor } \\
\text { Pós-herpética; NPT: Neuropa } \\
\text { nica; PF: Paralisia facial; SW: Síndr } \\
\text { dicou que queixas da mastiqacão v }\end{array}$ & $\begin{array}{l}\text { her e teste T de Student. } \\
\text { Disfunção Temporomandibular; SAB: } \\
\text { Facial Idiopática Persistente; NPH: } \\
\text { ia Pós-traumática; CC: Cefaleia } \\
\text { me de Wallemberg. } \\
\text { riaram entre os arupos, sendo menos }\end{array}$ \\
\hline 11$)$ & & $\begin{array}{l}\text { cou que queıxas da mastigaça } \\
\text { nos controles. }\end{array}$ & res grupos, ser \\
\hline
\end{tabular}


Tabela 16 - Características dentais ao exame clínico: comparação entre os diagnósticos $(\mathrm{N}=123)$.

\begin{tabular}{|c|c|c|c|c|c|c|}
\hline & $\begin{array}{c}\text { Características } \\
\text { oclusais (\%) }\end{array}$ & $\begin{array}{c}\text { Edentulismo } \\
(\%)\end{array}$ & $\begin{array}{c}\text { Dentes } \\
(\%)\end{array}$ & $\begin{array}{c}\text { Periodonto } \\
(\%)\end{array}$ & Mucosa (\%) & Língua (\%) \\
\hline NIT $^{* *}$ & $\begin{array}{l}\text { M profunda: } 4 \\
(13,8)^{\star \star} \\
\text { Overjet: } 2(6,9) \\
\text { M cruzada: } 2 \\
(6,9)\end{array}$ & $10(34,5)$ & $\begin{array}{l}\text { Cáries: } 2 \\
(6,9)\end{array}$ & $\begin{array}{l}\text { Gengivite: } 3 \\
(10,3) \\
\text { P leve: } 1 \\
(3,4){ }^{* *} \\
\text { P moderada: } \\
2(6,9) \\
\text { P grave: } 2 \\
(6,9)\end{array}$ & $\begin{array}{l}\text { H traumática: } 1 \\
(3,4) \\
\text { Úlcera: } 1(3,4) * * \\
\text { Candidíase: } 1 \\
(3,4)\end{array}$ & $\begin{array}{l}\text { Fissurada: } 4 \\
(13,8) \\
\text { Saburrosa: } 5 \\
(17,2) \\
\text { Ressecada: } 2 \\
(6,9)\end{array}$ \\
\hline DTM & $\begin{array}{l}\text { M aberta: } 3(27,3) \\
\text { M profunda: } 2 \\
(18,2)\end{array}$ & $2(18,2)$ & - & $\begin{array}{l}\text { Gengivite: } 1 \\
(9,1)\end{array}$ & $\begin{array}{l}\text { Líquen plano: } 2 \\
(18,2)\end{array}$ & $\begin{array}{l}\text { Fissurada: } 1 \\
(9,1) \\
\text { Ressecada: } 1 \\
(9,1)\end{array}$ \\
\hline SAB & - & $2(25,0)$ & $\begin{array}{l}\text { Cáries: } 2 \\
(25,0)\end{array}$ & $\begin{array}{l}\text { Gengivite: } 1 \\
(12,5) \\
\text { P moderada: } \\
2(25,0)\end{array}$ & Úlcera: $1(12,5)$ & $\begin{array}{l}\text { Fissurada: } 5 \\
(62,5) \\
\text { Saburrosa: } 1 \\
(12,5)\end{array}$ \\
\hline DFIP & $\begin{array}{l}\text { M cruzada } 1 \\
(12,5) \\
\text { M profunda } 2 \\
(25,0) \\
\text { Overjet } 1(12,5)\end{array}$ & $1(12,5)$ & $\begin{array}{l}\text { D } \\
\text { fraturados: } \\
1(12,5) * *\end{array}$ & $\begin{array}{l}\text { Gengivite: } 1 \\
(12,5) \\
\text { P grave: } 1 \\
(12,5)\end{array}$ & - & $\begin{array}{l}\text { Fissurada: } 2 \\
(25,0)\end{array}$ \\
\hline Fibromialgia & $\begin{array}{l}\text { M profunda: } 2 \\
(25,0)\end{array}$ & $4(50,0)$ & $\begin{array}{l}\text { Cáries: } 1 \\
(12,5)\end{array}$ & - & Úlcera: $1(12,5)$ & $\begin{array}{l}\text { Fissurada: } 3 \\
(37,5) \\
\text { Ressecada: } 1 \\
(12,5)\end{array}$ \\
\hline NPH & $\begin{array}{l}\text { M profunda: } 1 \\
(16,7)\end{array}$ & $4(66,7)$ & - & $\begin{array}{l}P \text { grave: } 1 \\
(16,7)\end{array}$ & $\begin{array}{l}\text { Máculas escuras: } \\
2(33,3)\end{array}$ & - \\
\hline NPT & $\begin{array}{l}\text { Overjet: } 1(20,0) \\
\text { M cruzada e } \\
\text { profunda: } 1(20,0)\end{array}$ & - & $\begin{array}{l}\text { D } \\
\text { fraturados: } \\
1(20,0)\end{array}$ & $\begin{array}{l}\text { Gengivite: } 1 \\
(20,0)\end{array}$ & - & $\begin{array}{l}\text { Eritematosa: } \\
1(20,0)\end{array}$ \\
\hline CC & $\begin{array}{l}\text { M cruzada: } 1 \\
(50,0)\end{array}$ & - & - & $\begin{array}{l}\text { P leve: } 1 \\
(50,0)\end{array}$ & - & $\begin{array}{l}\text { Saburrosa: } 1 \\
(50,0) \\
\text { Eritematosa: } 1 \\
(50,0)\end{array}$ \\
\hline PF & - & $1(33,3)$ & - & $\begin{array}{l}\text { P moderada: } \\
2(66,7)\end{array}$ & $\begin{array}{l}\mathrm{H} \\
\text { traumática:1(33,3) }\end{array}$ & - \\
\hline SW & $\begin{array}{l}\text { M profunda: } 1 \\
(50,0) \\
\text { M cruzada: } 1 \\
(50,0)\end{array}$ & - & - & $\begin{array}{l}P \text { moderada: } \\
1(50,0)\end{array}$ & - & - \\
\hline Controle & $\begin{array}{l}\text { Overjet: } 1(2,4) \\
\text { M cruzada: } 5 \\
(12,2) \\
\text { M aberta: } 1(2,4) \\
\text { M profunda: } 1 \\
(2,4)\end{array}$ & $15(36,6)$ & $\begin{array}{l}\text { Cáries: } 2 \\
(4,9) \\
\text { D } \\
\text { fraturados: } \\
2(4,9) \\
\text { Raiz } \\
\text { residual: } 1 \\
(2,4)\end{array}$ & $\begin{array}{l}\text { Gengivite: } 3 \\
(7,3) \\
\text { P leve: } 3 \\
(7,3) \\
\text { P moderada: } \\
3(7,3) \\
\text { P grave: } 3 \\
(7,3)\end{array}$ & $\begin{array}{l}\text { Úlcera: } 2(4,9) \\
\text { H traumática: } 1 \\
(2,4) \\
\text { Candidíase: } 1 \\
(2,4)\end{array}$ & $\begin{array}{l}\text { Fissurada: } 14 \\
(34,2) \\
\text { Saburrosa: } 6 \\
(14,7)\end{array}$ \\
\hline TOTAL & $\begin{array}{l}\text { M aberta: } 5(4,0) \\
\text { M cruzada: } 11 \\
(8,9) \\
\text { M profunda: } 17 \\
(13,8) \\
\text { Overjet: } 5(4,1)\end{array}$ & $39(31,7)$ & $\begin{array}{l}\text { Cáries: } 7 \\
(5,7) \\
\text { D } \\
\text { fraturados: } \\
4(3,3) \\
\text { Raiz } \\
\text { residual: } 1 \\
(0,8)\end{array}$ & $\begin{array}{l}\text { Gengivite: } 10 \\
(8,1) \\
\text { P leve: } 5 \\
(4,1) \\
\text { P moderada: } \\
10(8,1) \\
\text { P grave: } 7 \\
(5,7)\end{array}$ & $\begin{array}{l}\text { Úlcera: } 5(4,1) \\
\text { Máculas escuras: } \\
2(1,6) \\
\text { Líquen plano: } 2 \\
(1,6) I \\
\text { H traumática: } 3 \\
(2,4) \\
\text { Candidíase: } 2 \\
(1,6)\end{array}$ & $\begin{array}{l}\text { Fissurada: } 29 \\
(23,5) \\
\text { Saburrosa: } \\
13(10,5) \\
\text { Eritematosa: } \\
2(1,6) \\
\text { Ressecada: } 4 \\
(3,3)\end{array}$ \\
\hline$p^{*}$ & 0,055 & 0,493 & 0,799 & 0,142 & $0,014^{* * *}$ & 0,003 \\
\hline $\begin{array}{ll}\left(^{*}\right) & \text { Testes Qu } \\
\left({ }^{* *}\right) & \text { NIT: Neu } \\
& \text { Bucal; D } \\
& \text { traumátic } \\
& \text { dentes; P }\end{array}$ & $\begin{array}{l}\text {-quadrado de Pears } \\
\text { lgia Idiopática do T } \\
\text { IP: Dor Facial Idio } \\
\text { CC: Cefaleia Cervi } \\
\text { periodontite; H: hipe }\end{array}$ & $\begin{array}{l}\text { n, exato de Fishe } \\
\text { igêmeo; DTM: Di } \\
\text { iática Persistente } \\
\text { ogênica; PF: Par } \\
\text { plasia. }\end{array}$ & $\begin{array}{l}\text { e teste T de } \\
\text { função Tem } \\
\text { NPH: Neu } \\
\text { lisia facial; S }\end{array}$ & $\begin{array}{l}\text { tudent. } \\
\text { oromandibular } \\
\text { algia Pós-herp } \\
\text { N: Síndrome c }\end{array}$ & $\begin{array}{l}\text { AB: Síndrome da } \\
\text { ca; NPT: Neurop } \\
\text { Wallemberg; M: m }\end{array}$ & $\begin{array}{l}\text { dência } \\
\text { Pós- } \\
\text { ida; D: }\end{array}$ \\
\hline $\begin{array}{l}\left(^{* * *}\right) \begin{array}{l}\text { Teste } Z \text { it } \\
\text { em doent }\end{array}\end{array}$ & $\begin{array}{l}\text { dicou que anormali } \\
\text { s com SAB. }\end{array}$ & des da mucosa & al (resseca & ento) e língua & ssuras) foram mai & omuns \\
\hline
\end{tabular}


Tabela 17 - Características mandibulares ao exame clínico: comparação entre os diagnósticos $(\mathrm{N}=123)$

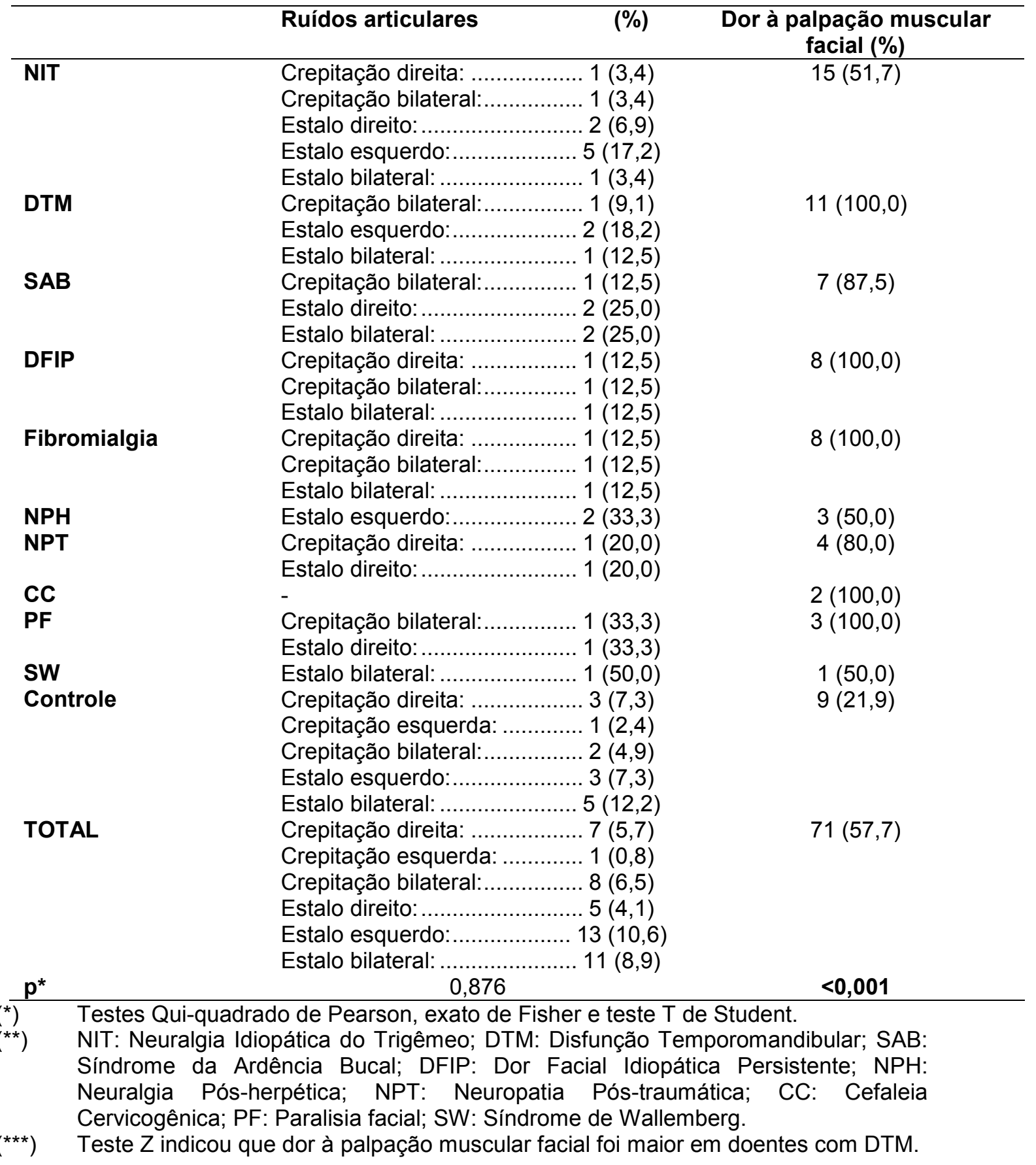

Quanto maior a altura, maior o incômodo de mastigação $(p=0,004)$; idade também foi maior quanto maiores o peso $(p=0,007)$, a intensidade da dor $(p=0,017)$, a intensidade de incômodo de mastigação $(p=0,023)$ e a dormência e disestesia $(p<0,001)$. Duração da dor se correlacionou positivamente com intensidade de dor $(p<0,001)$, intensidade 
de incômodo de mastigação $(p=0,001)$, dormência $(p=0,003)$ e disestesia $(p=0,002)$; quanto maior a duração, maior a prevalência de cefaleia $(p<0,001)$. Intensidade da dor se correlacionou positivamente com incômodo de mastigação $(p<0,001)$, dormência e disestesia $(p<0,001)$, incômodo de mastigação com disestesia e dormência $(p<0,001)$, e por fim, dormência com disestesia $(p<0,001)$.

Quanto maior a duração da dor, mais descritores espontâneos $(p=0,042)$ e maior sua intensidade $(p=0,036)$. Na presença de cefaleia, houve mais descritores da dor $(p=0,005)$ e também maior intensidade de dor $(p<0,001)$

Mulheres apresentaram maior intensidade $(p<0,001)$ e duração da dor $(p<0,001)$, mais incômodo de mastigação $(p<0,001)$, mais dormência e mais disestesia $(p=0,001)$. A presença de infecção oral se associou com menores limiares dolorosos de profundidade $(p=0,016)$. Quanto mais ramos trigeminais associados ou maior a àrea de distribuição de dor, maior a intensidade da mesma $(p<0,001)$. Não houve associações entre raça, estado civil e quaisquer variáveis.

Quando analisadas as associações com variáveis sensitivas, houve significância positiva entre cefaleia e limiares térmicos ao frio $(p=0,031)$, limiares térmicos ao calor $(p<0,001)$ e limiares dolorosos de profundidade $\quad(p<0,001) ; \quad$ correlacionaram-se positivamente: limiares mecânicos vibratórios e intensidade de dor $(p=0,032)$, limiares mecânicos vibratórios e incômodo de mastigação $(p=0,023)$, limiares mecânicos elétricos e descritores $(p=0,028)$, limiares elétricos e incômodo de 
mastigação $(p=0,029)$, intensidade de dor e limiares dolorosos de superfície $(p=0,024)$, limiares gustativos com descritores de dor $(p=0,009)$, limiar doce e incômodo da mastigação $(p=0,049)$. Por fim, quanto maiores os limiares dolorosos de profundidade, menor a duração da dor $(p=0,005)$, a intensidade de dor $(p=0,001)$ e incômodo de mastigação $(p=0,035)$.

\subsection{Boca seca e fluxo salivar $(\mathrm{N}=123)$}

As Tabelas de 18 a 20 apresentam os resultados da avaliação de xerostomia e fatores correlacionados. Não houve diferenças significantes entre os grupos com relação à queixa de boca seca $(p=0,875)$, porém, os doentes em geral queixaram-se mais do que os controles $(p=0,032)$. Dificuldade de falar e evitação de alimentos devido à boca seca foram mais comuns em doentes com DFIP ( $p=0,010$ e $p=0,005$ respectivamente) (Tabelas 18 e 19). Doentes com SAB e NPT apresentaram uso de balas e chicletes para o incômodo de xerostomia $(p=0,014)$ e doentes com SAB, mais frequentemente, ardor bucal $(p<0,001)$. Percepção subjetiva de secura em olhos $(p=0,008)$, pele $(p=0,047)$ e mucosa nasal $(p=0,029)$ foram estatisticamente maiores em alguns grupos de doentes (Tabela 20). 
Tabela 18 - Queixas subjetivas de xerostomia (boca seca e dificuldade de mastigar ou falar): comparação entre os diagnósticos $(\mathrm{N}=123)$

\begin{tabular}{|c|c|c|c|c|}
\hline & Boca seca (\%) & $\begin{array}{c}\text { Dificuldade de } \\
\text { mastigar (\%) }\end{array}$ & $\begin{array}{c}\text { Dificuldade de falar } \\
(\%)\end{array}$ \\
\hline \multicolumn{2}{|l|}{ NIT } & $15(51,7)$ & $4(14,8)$ & $2(6,9)$ \\
\hline \multicolumn{2}{|l|}{ DTM } & $4(36,4)$ & - & $1(9,1)$ \\
\hline \multicolumn{2}{|l|}{ SAB } & $5(62,5)$ & - & $1(12,5)$ \\
\hline \multicolumn{2}{|l|}{ DFIP } & $5(62,5)$ & $3(37,5)$ & $5(62,5)$ \\
\hline \multicolumn{2}{|c|}{ Fibromialgia } & $5(62,5)$ & $2(25,0)$ & $2(25,0)$ \\
\hline \multicolumn{2}{|l|}{ NPH } & $3(50,0)$ & $1(16,7)$ & $1(16,7)$ \\
\hline \multicolumn{2}{|l|}{ NPT } & $3(60,0)$ & - & - \\
\hline \multicolumn{2}{|l|}{ CC } & $2(100,0)$ & - & - \\
\hline \multicolumn{2}{|l|}{ PF } & $2(66,7)$ & $1(33,3)$ & $1(33,3)$ \\
\hline \multicolumn{2}{|l|}{ sw } & $2(100,0)$ & - & - \\
\hline \multicolumn{2}{|l|}{ Controle } & $15(36,6)$ & $2(4,9)$ & $3(7,3)$ \\
\hline \multicolumn{2}{|l|}{ TOTAL } & $61(49,6)$ & $13(10,6)$ & $16(13,0)$ \\
\hline \multicolumn{2}{|l|}{$\mathbf{p}^{*}$} & 0,875 & 0,125 & $0,010^{* * *}$ \\
\hline \multicolumn{5}{|c|}{$\begin{array}{l}\left(^{*}\right) \\
\left({ }^{* *}\right) \\
\text { NIT: Neuralgia Idiopática do Trigêmeo; DTM: Disfunção Temporomandibular; SAB: } \\
\text { Síndrome da Ardência Bucal; DFIP: Dor Facial Idiopática Persistente; NPH: } \\
\text { Neuralgia Pós-herpética; NPT: Neuropatia Pós-traumática; CC: Cefaleia } \\
\text { Cervicogênica; PF: Paralisia facial; SW: Síndrome de Wallemberg. }\end{array}$} \\
\hline
\end{tabular}


Tabela 19 - Fatores associados às queixas subjetivas de xerostomia (sede, beber líquidos e evitar alimentos): comparação entre os diagnósticos $(\mathrm{N}=123)$

\begin{tabular}{|c|c|c|c|c|}
\hline & & $\begin{array}{c}\text { Sede durante a noite } \\
(\%)\end{array}$ & $\begin{array}{c}\text { Beber líquidos para } \\
\text { engolir (\%) }\end{array}$ & $\begin{array}{c}\text { Evitar alimentos pela } \\
\text { boca seca }(\%)\end{array}$ \\
\hline \multicolumn{2}{|l|}{ NIT } & $10(34,5)$ & $3(10,3)$ & $1(3,4)$ \\
\hline \multicolumn{2}{|l|}{ DTM } & $7(63,6)$ & $4(36,4)$ & $1(9,1)$ \\
\hline \multicolumn{2}{|l|}{ SAB } & $6(37,5)$ & $1(12,5)$ & $1(12,5)$ \\
\hline \multicolumn{2}{|l|}{ DFIP } & $4(50,0)$ & - & $3(37,5)$ \\
\hline \multicolumn{2}{|c|}{ Fibromialgia } & $5(62,5)$ & $2(25,0)$ & - \\
\hline \multicolumn{2}{|l|}{ NPH } & $4(66,7)$ & $2(33,3)$ & $1(16,7)$ \\
\hline \multicolumn{2}{|l|}{ NPT } & $3(60,0)$ & $1(20,0)$ & - \\
\hline \multicolumn{2}{|l|}{ CC } & $1(50,0)$ & - & $1(50,0)$ \\
\hline \multicolumn{2}{|l|}{ PF } & $2(66,7)$ & $2(66,7)$ & - \\
\hline \multicolumn{2}{|l|}{ sw } & - & $1(50,0)$ & - \\
\hline \multicolumn{2}{|l|}{ Controle } & $16(39,0)$ & $4(9,8)$ & - \\
\hline \multicolumn{2}{|l|}{ TOTAL } & $55(44,7)$ & $20(16,3)$ & $8(6,5)$ \\
\hline \multicolumn{2}{|l|}{$\mathbf{p}^{*}$} & 0,220 & 0,090 & 0,005 \\
\hline \multicolumn{5}{|c|}{$\begin{array}{l}\left(^{*}\right) \\
\left({ }^{* *}\right) \\
\text { NIT: Neuralgia Idiopática do Trigêmeo; DTM: Disfunção Temporomandibular; SAB: } \\
\text { Síndrome da Ardência Bucal; DFIP: Dor Facial Idiopática Persistente; NPH: } \\
\text { Neuralgia Pós-herpética; NPT: Neuropatia Pós-traumática; CC: Cefaleia } \\
\text { Cervicogênica; PF: Paralisia facial; SW: Síndrome de Wallemberg. }\end{array}$} \\
\hline$(* * *)$ & $\begin{array}{l}\text { Teste } \\
\text { com [ }\end{array}$ & ou que evitar alimentos & ela boca seca foi $m$ & comum em doentes \\
\hline
\end{tabular}


Tabela 20 - Queixas subjetivas de xerostomia e fatores associados (uso de balas/chicletes, mau hálito, mucosas e pele seca, ardor e copos diários de água): comparação entre os diagnósticos $(\mathrm{N}=123)$

\begin{tabular}{|c|c|c|c|c|c|c|c|}
\hline & $\begin{array}{c}\text { Uso de } \\
\text { balas/ } \\
\text { chicletes }\end{array}$ & $\begin{array}{c}\text { Mau } \\
\text { hálito }\end{array}$ & $\begin{array}{l}\text { Olhos } \\
\text { secos }\end{array}$ & $\begin{array}{l}\text { Pele } \\
\text { seca }\end{array}$ & $\begin{array}{l}\text { Nariz } \\
\text { seco }\end{array}$ & $\begin{array}{l}\text { Ardor } \\
\text { bucal }\end{array}$ & $\begin{array}{c}\text { Copos } \\
\text { diários de } \\
\text { água }\end{array}$ \\
\hline NIT & $2(6,9)$ & $7(24,1)$ & $10(34,5)$ & $9(31,0)$ & $9(31,0)$ & $5(17,2)$ & $\begin{array}{c}4,45 \pm 2,59 \\
(1-10)\end{array}$ \\
\hline DTM & $1(9,1)$ & $2(18,2)$ & $7(63,6)$ & $9(81,8)$ & $9(81,8)$ & $1(9,1)$ & $\begin{array}{c}5,27 \pm 4,12 \\
(2-15)\end{array}$ \\
\hline SAB & $3(37,5)$ & $3(37,5)$ & $4(50,0)$ & $5(62,5)$ & $5(62,5)$ & $7(87,5)$ & $\begin{array}{c}5,25 \pm 3,06 \\
(1-10)\end{array}$ \\
\hline DFIP & $1(12,5)$ & $4(50,0)$ & $3(37,5)$ & $5(62,5)$ & $2(25,0)$ & $1(12,5)$ & $\begin{array}{c}6,25 \pm 4,27 \\
(0-15)\end{array}$ \\
\hline Fibromialgia & $2(25,0)$ & $3(37,5)$ & $4(50,0)$ & $7(87,5)$ & $5(62,5)$ & $1(12,5)$ & $\begin{array}{c}7,25 \pm 5,42 \\
(2-15)\end{array}$ \\
\hline NPH & $1(16,7)$ & $1(16,7)$ & - & $3(50,0)$ & $2(33,3)$ & - & $\begin{array}{c}6,67 \pm 4,80 \\
(2-15)\end{array}$ \\
\hline NPT & $2(40,0)$ & $1(20,0)$ & $4(80,0)$ & $4(80,0)$ & $2(40,0)$ & $2(40,0)$ & $\begin{array}{c}11,20 \pm 9,20 \\
(3-22)\end{array}$ \\
\hline CC & $2(100,0)$ & $1(50,0)$ & $2(100,0)$ & $1(50,0)$ & $2(100,0)$ & $1(50,0)$ & $\begin{array}{c}3,00 \pm 3,00 \\
(0-6)\end{array}$ \\
\hline PF & - & $2(66,7)$ & $2(66,7)$ & $2(66,7)$ & $2(66,7)$ & $1(33,3)$ & $\begin{array}{c}5,67 \pm 2,08 \\
(4-8)\end{array}$ \\
\hline sw & $1(50,0)$ & - & $1(50,0)$ & $2(100,0)$ & $1(50,0)$ & - & $\begin{array}{c}13,00 \pm 9,90 \\
(6-20)\end{array}$ \\
\hline Controle & $4(9,8)$ & $9(22,0)$ & $7(17,1)$ & $18(43,9)$ & $11(26,8)$ & $2(4,9)$ & $\begin{array}{c}5,07 \pm 2,53 \\
(0-10)\end{array}$ \\
\hline TOTAL & $19(15,4)$ & $33(26,8)$ & $44(35,8)$ & $65(52,8)$ & $50(40,7)$ & $21(17,1)$ & $\begin{array}{c}5,61 \pm 4,00 \\
(0-22)\end{array}$ \\
\hline $\mathbf{p}^{*}$ & $0,014^{\star * *}$ & 0,602 & 0,008 & 0,047 & 0,029 & $<0,001$ & $<0,001$ \\
\hline
\end{tabular}

$\left(^{*}\right)$ Testes Qui-quadrado de Pearson, exato de Fisher e teste T de Student.

$\left({ }^{*}\right) \quad$ NIT: Neuralgia Idiopática do Trigêmeo; DTM: Disfunção Temporomandibular; SAB: Síndrome da Ardência Bucal; DFIP: Dor Facial Idiopática Persistente; NPH: Neuralgia Pós-herpética; NPT: Neuropatia Pós-traumática; CC: Cefaleia Cervicogênica; PF: Paralisia facial; SW: Síndrome de Wallemberg.

${ }^{(* * *}$ Teste $Z$ indicou que uso de balas / chicletes foi mais frequente em doentes com SAB e NPT, olhos secos foram mais comuns em NPT e DTM, pele seca foi mais frequente em DTM, fibromialgia e NPT, nariz seco foi mais frequente em DTM e ardor bucal foi mais comum em SAB.

A Tabela 21 apresenta outras queixas relativas ao sistema digestivo, investigadas nestes doentes. Somente houve diferença com relação à queixa de dor de estômago, mais comum nos doentes com fibromialgia e DFIP $(p=0,018)$. Fibromialgia também teve a pior qualidade de digestão, embora não tenha sido significante. 
Outras alterações orais também puderam ser observadas, como sensação de paladar diminuído, maior em SAB, DFIP e NPT $(p=0,028)$, gosto fantasma em fibromialgia, SAB e DFIP $(p=0,001)$, boca seca durante as refeições em DFIP e fibromialgia $(p<0,001)$ e dificuldade no uso de próteses dentárias devido à xerostomia em fibromialgia $(p=0,038)($ Tabela 22). 
Tabela 21 - Queixas subjetivas de xerostomia e fatores associados relacionados ao sistema digestivo: comparação entre os diagnósticos $(\mathrm{N}=123)$

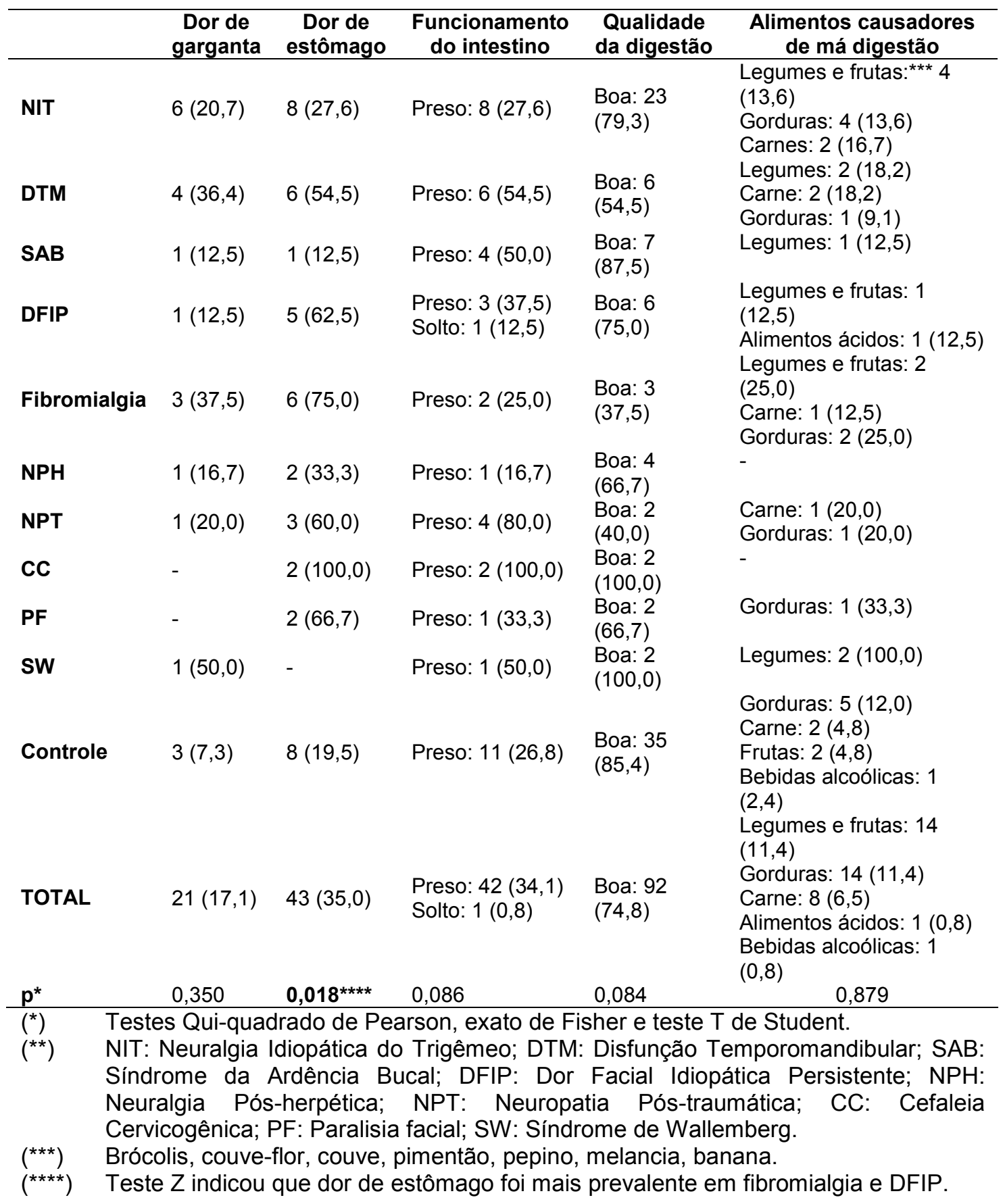


Tabela 22 - Queixas subjetivas de xerostomia e fatores associados (saliva e paladar): comparação entre os diagnósticos $(\mathrm{N}=123)$

\begin{tabular}{lccccc}
\hline & $\begin{array}{c}\text { Dificuldade } \\
\text { engolir } \\
\text { saliva (\%) }\end{array}$ & $\begin{array}{c}\text { Paladar } \\
\text { diminuído } \\
(\%)\end{array}$ & $\begin{array}{c}\text { Boca seca } \\
\text { durante } \\
\text { refeições (\%) }\end{array}$ & $\begin{array}{c}\text { Paladar } \\
\text { alterado (\%) }\end{array}$ & $\begin{array}{c}\text { Dificuldade de usar } \\
\text { prótese pela boca } \\
\text { seca (\%) }\end{array}$ \\
\hline NIT & $2(6,9)$ & $6(20,7)$ & $2(6,9)$ & $3(10,3)$ & $2(6,9)$ \\
DTM & - & $2(18,2)$ & - & $2(18,2)$ & $1(9,1)$ \\
SAB & $2(25,0)$ & $4(50,0)$ & $1(12,5)$ & $3(37,5)$ & $1(12,5)$ \\
DFIP & $3(37,5)$ & $4(50,0)$ & $2(25,0)$ & $3(37,5)$ & - \\
Fibromialgia & $1(12,5)$ & $1(12,5)$ & $2(25,0)$ & $5(62,5)$ & $4(50,0)$ \\
NPH & - & $1(16,7)$ & $1(16,7)$ & - & - \\
NPT & $1(20,0)$ & $3(60,0)$ & $1(20,0)$ & $1(20,0)$ & $1(20,0)$ \\
CC & - & - & $1(50,0)$ & $2(100,0)$ & - \\
PF & - & $2(66,7)$ & $1(33,3)$ & $3(100,0)$ & $1(33,3)$ \\
SW & - & - & - & $1(50,0)$ & - \\
Controle & $1(2,4)$ & $4(9,8)$ & $3(7,3)$ & $8(19,5)$ & - \\
TOTAL & $11(8,9)$ & $28(22,8)$ & $15(12,2)$ & $31(25,2)$ & $10(8,1)$ \\
$\mathbf{p}^{*}$ & 0,068 & $\mathbf{0 , 0 2 8} \mathbf{8}^{* *}$ & $<0,001$ & $\mathbf{0 , 0 0 1}$ & $\mathbf{0 , 0 3 8}$ \\
\hline
\end{tabular}

(*) Testes Qui-quadrado de Pearson, exato de Fisher e teste T de Student.

$\left({ }^{* *}\right) \quad$ NIT: Neuralgia Idiopática do Trigêmeo; DTM: Disfunção Temporomandibular; SAB: Síndrome da Ardência Bucal; DFIP: Dor Facial Idiopática Persistente; NPH: Neuralgia Pós-herpética; NPT: Neuropatia Pós-traumática; CC: Cefaleia Cervicogênica; PF: Paralisia facial; SW: Síndrome de Wallemberg.

${ }^{(* * *}$ Teste $Z$ indicou que paladar diminuído foi mais frequente em SAB, DFIP e NPT, boca seca durante as refeições foi mais frequente em DFIP e fibromialgia, paladar alterado foi mais comum em fibromialgia, SAB e DFIP e dificuldade de usar a prótese em fibromialgia.

Houve associação entre percepção de boca seca e redução de paladar $(p=0,028)$, percepção de boca seca e sabor alterado $(p=0,003)$, gosto fantasma e redução de paladar $(p<0,001)$, redução de paladar e queimor bucal $(p<0,001)$, sabor alterado e queimor oral $(p=0,006)$, redução de paladar e queimor no estômago $(p=0,015)$, redução de paladar e limiares dolorosos de profundidade $(p=0,002)$, gosto fantasma e percepção de mau hálito $(p<0,001)$, sabor alterado e queimor no estômago $(p=0,002)$, percepção de mau hálito e queimor no estômago $(p=0,002)$, dor de estômago e intensidade da dor $(p=0,027)$, percepção de boca seca e 
intensidade de dor $(p=0,033)$, perda de paladar e intensidade de dor $(p=0,024)$, queimor na boca e intensidade da dor $(p=0,006)$, dor de garganta e intensidade da dor ( $p=0,023)$; dor de cabeça, dor de garganta e limiares tácteis $(p=0,020)$, dor de garganta e limiares dolorosos de superfície $(p=0,030)$, queimor no estômago e o limiar gustativo salgado $(p=0,018)$, incômodo da mastigação e boca seca $(p=0,005)$, incômodo da mastigação e perda de paladar ( $p=0,007)$, incômodo da mastigação e queimação na boca $(p<0,001)$, incômodo da mastigação e dor de garganta $(p=0,024)$, incômodo da mastigação e dor de estômago $(p=0,003)$, dormência subjetiva e perda de paladar $(p<0,001)$, dormência subjetiva e queimação oral $(p<0,001)$, dormência subjetiva e dor de estômago $(p=0,013)$, disestesia e perda de paladar $(p=0,001)$, queimação na boca e disestesia $(p<0,001)$, disestesia e dor de estômago $(p=0,045)$.

O fluxo salivar foi menor em indivíduos que apresentavam cefaleia $(p=0,028)$ e que tinham perda de paladar $(p=0,028)$. Houve correlação negativa entre fluxo salivar e limiares térmicos ao frio $(p=0,022)$. Houve associação entre as seguintes variáveis: cefaleia e queimação na boca $(p=0,028)$, cefaleia e dor de garganta $(p=0,028)$, cefaleia e dor de estômago $(p=0,013)$, cefaleia e bom funcionamento do intestino $(p=0,041)$, presença de infecção oral e bom funcionamento do intestino $(p=0,034)$.

Não houve diferenças estatísticas entre os grupos com relação ao fluxo salivar, porém em geral os valores foram menores nos doentes do que nos controles, exceto em DTM e NPT (Figura 47). 
Figura 47 - quantitativa de fluxo salivar: comparação entre os diagnósticos $(\mathrm{N}=123)$

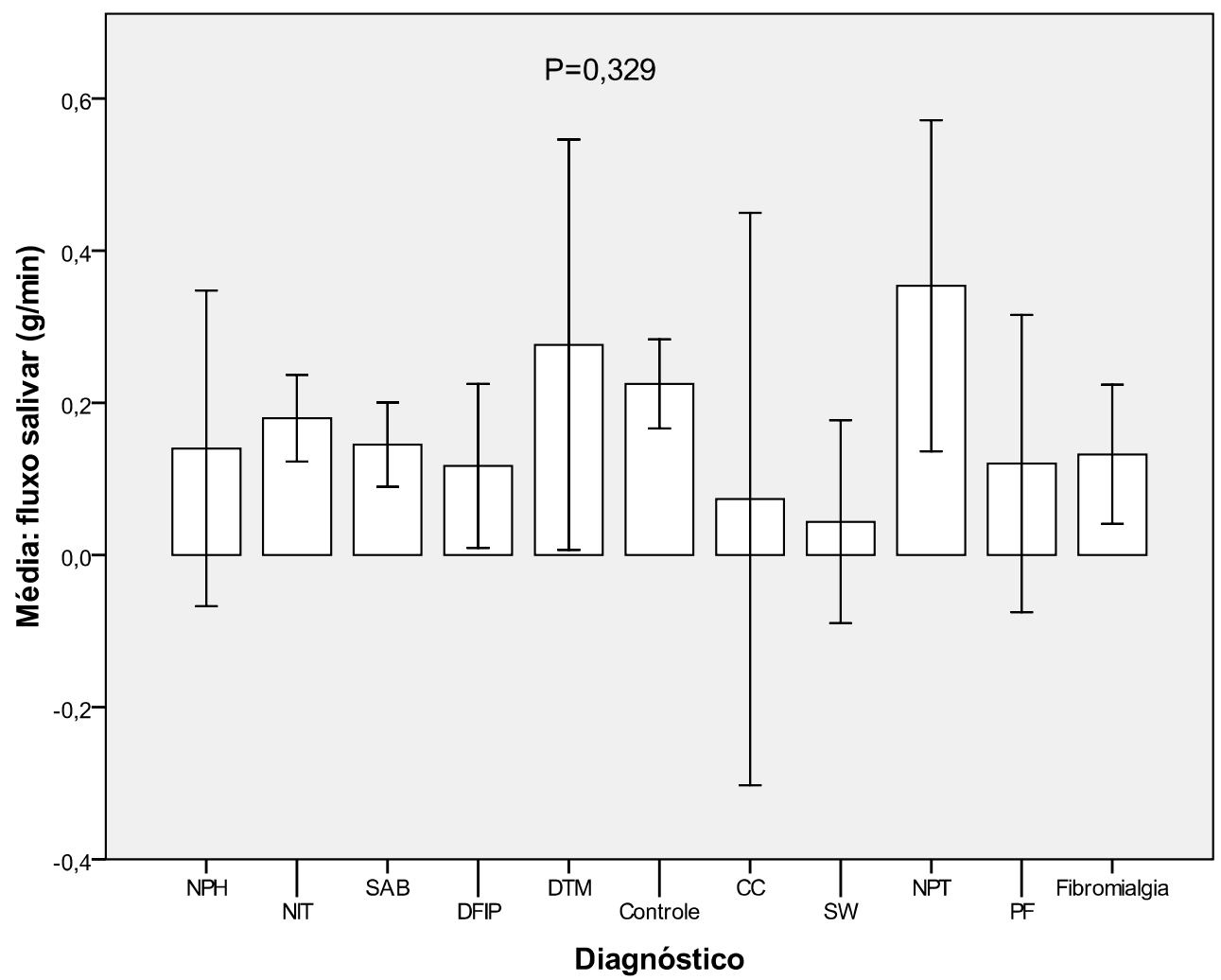

$\left.{ }^{*}\right) \quad$ Teste ANOVA 1 fator. As barras correspondem ao intervalo de confiança 95\%

$\left({ }^{* *}\right) \quad$ NIT: Neuralgia Idiopática do Trigêmeo; DTM: Disfunção Temporomandibular; SAB: Síndrome da Ardência Bucal; DFIP: Dor Facial Idiopática Persistente; NPH: Neuralgia Pós-herpética; NPT: Neuropatia Pós-traumática; CC: Cefaleia Cervicogênica; PF: Paralisia facial; SW: Síndrome de Wallemberg. 


\section{DISCUSSÃO}

Este estudo apresentou a evolução das avaliações em dor orofacial através de TSQ, inicialmente por metodologia desenvolvida no serviço, e posteriormente através de equipamentos internacionalmente reconhecidos com esta finalidade (Pigg et al., 2009). A avaliação através dos instrumentos nacionais permitiu amplificar de maneira pioneira os tipos de dados que podem ser obtidos pela metodologia internacional, o que resultou em inúmeras publicações e teses a este respeito (Alvarez, 2008; Alvarez et al., 2007; Siqueira, 2006; Siqueira et al., 2006a; Siqueira et al., 2006b; Siqueira et al., 2006c; Siviero et al., 2010; Arap et al., 2010; Siviero et al., 2011a; Siviero et al., 2011b; Brazolotto, 2011, Tibano, 2011; Siviero, 2011). Através desses trabalhos, desenvolveu-se a linha de pesquisa aqui apresentada, que tem sido reconhecida, além das publicações, por verbas de apoio de entidades como a FAPESP, e por seleção de trabalhos para apresentação oral em congressos internacionais (Siqueira, 2009). Não foi possível realizar análise de confidencialidade entre as metodologias porque os exames foram realizados em doentes distintos, além do fato de as amostras apresentarem diferenças com relação à área facial afetada (tanto em ramo quanto em lado) ( $p=0,004$ e $p<0,001$ respectivamente) e também com relação aos diagnósticos $(p<0,001)$. É provável que a discrepância observada na avaliação de sensibilidade entre as amostras (Figuras 1 a 5) seja devido a estas diferenças, uma vez que a amostra 1 tem mais doentes com dor neuropática e menos controles. Entretanto, foram investigados os 
aspectos relacionados à sensibilidade orofacial de 459 sujeitos, além da avaliação completa orofacial e de boca seca de 123 destes indivíduos, não havendo na revisão de literatura realizada estudos que tenham examinado esses aspectos de maneira comparativa entre as doenças. Esses dados podem contribuir para a compreensão dos mecanismos fisiopatológicos da dor orofacial.

\subsection{Testes sensitivos quantitativos (TSQ): avaliação somestésica térmica, táctil e dolorosa $(\mathrm{N}=459)$}

Variações nos limiares sensitivos podem ser observados em doentes com dor crônica, e hipoestesia térmica e mecânica, e hiperalgesia táctil são conhecidos sinais de comprometimento do sistema nervoso central e / ou periférico na dor neuropática (Basbaum e Jessell, 2003; Teixeira, 1995). Nesta amostra, como em geral os doentes apresentaram dor unilateral, evidentemente que as anormalidades foram observadas no lado afetado. Queixa de dormência esteve presente inclusive em controles $(48,4 \%)$ e em doentes com diagnóstico não neuropático, como a DTM $(86,6 \%)$, e as razões para isso podem incluir a variabilidade de percepção subjetiva de sensibilidade e a integração constante de informações no sistema nervoso central envolvidas na consciência do meio externo (Basbaum e Jessell, 2003). Foram também observadas anormalidades sensitivas à distância, que devem estar relacionadas aos mesmos fenômenos. 
Nesta amostra, os limiares térmicos ao frio e ao calor foram maiores nos doentes que apresentavam NPH e SAB, especialmente no ramo oftálmico $(p<0,001)$; esses dados são similares aos observados anteriormente (Peterson e Rowbotham, 2010; Grushka e Sessle, 1998), e parecem indicar um maior comprometimento neuropático nessas condições quando comparadas a outras, mesmo a NIT. Na NPH, houve a maior freqüência de dormência quando comparada a outros grupos. É provável que os achados sinalizem um maior comprometimento nervoso (Eliav et al., 2007; Peterson e Rowbotham, 2010) tanto periférico como central (Jaaskelainen, 2004), que justificaria inclusive limiares maiores ao frio em extremidades, no caso dos doentes com SAB. Anormalidades tácteis de superfície e dolorosas de profundidade também foram maiores nos doentes com NPH e SAB, principalmente na região inervada pelo ramo oftálmico do nervo trigêmeo $(p<0,001)$, reforçando esses dados.

A sensibilidade mecânica dolorosa, realizada em região de músculos mastigatórios faciais, apresentou-se com limiares menores em alguns grupos de doentes, como no ramo oftálmico do lado oposto nos doentes com NPH e também em regiões de ramos maxilar e mandibular nos doentes com NIT e SAB, quando comparados aos controles $(p<0,001)$, o que indica sensibilização muscular nesses doentes; trata-se de uma informação relevante, uma vez que é comum encontrar alterações musculares mastigatórias secundárias ao diagnóstico principal, em especial DTM, o que é também causa de dor e deve ser identificada no momento da avaliação e do diagnóstico, para um melhor tratamento a ser estabelecido 
(Siqueira et al., 2007; Nobrega et al., 2007; Prado, 2002). De fato, as atividades mandibulares pioravam a dor em $17,9 \%$ dos doentes desta amostra, 58,5\% tiveram comprometimento da mastigação ( $p<0,001), 41,5 \%$ tinham mastigação ruim ou péssima, e cansaço e dor ao movimento mandibular foram comuns $(p<0,001$ e $p=0,009)$; houve uma tendência de unilateralização da mastigação, provavelmente pela dor, e muitos doentes inclusive tiveram abertura bucal menor do que $40 \mathrm{~mm}$, o que é considerado limitação (Siqueira e Ching, 1999). Como esperado, os doentes com DTM tiveram mais dor à palpação e seus limiares dolorosos de profundidade foram menores do que os controles nas regiões temporal $(p=0,015)$ e massetérica $(p=0,008)$, mas também em regiões à distância (tíbia, $p=0,050$ e mãos, $p=0,035)$.

A algiometria de superfície, por outro lado, apresentou limiares maiores em boa parte dos doentes quando comparados aos controles, o que caracteriza hipoalgesia e corresponde a sensibilização de áreas centrais (Teixeira et al., 1994; Siqueira e Teixeira, 2001). Nesse estudo, não só os doentes com dor neuropática tiveram esses limiares aumentados: a cronicidade da condição álgica leva a alterações centrais que podem estar por trás disso. Na fibromialgia, particularmente, os limiares álgicos foram maiores inclusive em áreas como as mãos $(p=0,037)$ e tíbia $(p=0,002)$, caracterizando a natureza sistêmica dessa condição.

Na NIT, houve maior freqüência de anormalidades tácteis no ramo mandibular $(p=0,009)$, o que corresponde à área mais afetada nesses doentes, e deve indicar um papel importante das fibras grossas no caráter 
neuropático dessa condição. A anormalidade clínica de disparos da dor por leve contato facial (Teixeira, 1998), que caracteriza a zona gatilho, também indica um comprometimento dessas fibras.

Apesar de a NPT ser caracterizada por lesão nervosa como causa da dor, através da formação de neuromas e microneuromas de amputação, gerando dor por desaferentação (Forssell et al., 2007; Niemi et al., 2009), apenas os limiares de dor de profundidade e de superfície foram encontrados diferentes dos outros grupos aqui estudados. Aparentemente, a $\mathrm{NPH}$ e a SAB parecem ser condições de maior comprometimento neuropático do que a NPT, e as razões para isso não são claras, mas podem indicar que a NPT tem um comprometimento mais periférico quando comparada à NPH e SAB.

Por outro lado, de uma maneira geral, os doentes com ND apresentaram os menores limiares em geral quando comparados aos outros, o que talvez reflita o fato de que estes doentes não apresentavam dor ou queixa de sensibilidade na região orofacial, e provavelmente a condição identificada foi subclínica. Esse achado indica que, mesmo em pacientes com Diabetes mellitus que não têm queixas orofaciais relacionadas à sensibilidade, pode haver um comprometimento da região antes que sejam percebidos (Arap et al., 2010).

O reflexo córneo-palpebral apresentou-se diferente dos controles nos doentes com NPH e também numericamente nos doentes com SW, o que pode reforçar o alto grau de comprometimento neurológico desses dois grupos, quando comparados aos outros, e pode ter se relacionado com a 
gravidade da lesão, já que quanto maiores foram as queixas de disestesia, maiores as alterações do reflexo $(p=0,024)$; além disso, quanto maior a duração da dor, também houve maior alteração do reflexo $(p<0,001)$.

\subsection{Testes sensitivos quantitativos (TSQ): avaliação somestésica vibratória e elétrica, gustativa e olfativa: amostra $2(\mathrm{~N}=123)$}

Neste estudo, não houve diferenças com relação aos limiares gustativos entre os grupos estudados, apesar das queixas de paladar diminuído e gosto fantasma em alguns grupos estudados. Porém, quando analisadas as médias gustativas, os doentes apresentaram limiares menores do que os controles, exceto pelos doentes com fibromialgia, que apresentaram limiares maiores $(p<0,001)$. A fibromialgia é uma condição conhecida em que os doentes referem dor nos quatro quadrantes do corpo; o caráter sistêmico dessa condição pode estar associado ao comprometimento da modulação da sensação dolorosa e que pode afetar a percepção sensitiva de uma maneira geral. É importante observar que, neste estudo, os subgrupos de doentes apresentaram número reduzido de indivíduos, o que pode ter afetado os resultados observados. Já os limiares olfativos foram particularmente maiores nos doentes com NPH, o que é compatível com nossos achados anteriores (Siviero et al., 2010), reforçando mais ainda o aspecto central de comprometimento neuropático desses indivíduos. 
Não foram observadas diferenças quanto aos limiares vibratórios, exceto pelos indivíduos com DTM apresentarem limiares menores do que os controles nas mãos. Já os limiares elétricos foram menores no ramo mandibular dos doentes com NIT, no lado oposto; porém, as razões para isso não são claras. Não houve diferenças entre os grupos com relação aos limiares elétricos dentários. É importante salientar que a sensibilidade dentária é mediada particularmente por fibras de fino calibre, relacionadas à condução dolorosa somente.

As correlações positivas encontradas entre diversas variáveis de sensibilidade indicam ainda que é provável que os limiares sensitivos de modalidades distintas sigam o mesmo padrão de aumento ou diminuição num mesmo indivíduo tanto em situações de normalidade como na dor crônica orofacial, já que essa característica foi observada tanto nos doentes quanto nos controles. Isso ocorreu inclusive entre modalidades somestésicas e gustativas. É possível que, na dor crônica orofacial, as anormalidades somestésicas relacionadas à sensibilização central acabem por promover alterações nos limiares gustativos não só em condições como a $S A B$, em que há dor intraoral na língua principalmente, mas também em outras condições relacionadas ao sistema trigeminal, como a NPH e a NIT (Siviero et al., 2010). Quanto maiores os limiares, de uma maneira geral, maior a intensidade de dormência e de disestesia, maior a intensidade e duração da dor e maior o incômodo de mastigação, o que sugere sensibilização central e hiperalgesia secundária (Sessle, 2000). 
Alguns limiares sensitivos (calor e dolorosos de profundidade) foram menores nas mulheres do que nos homens. Esse padrão já havia sido observado anteriormente em estudos de dor em ATM tanto em animais como em humanos, e indicam que o hormônio estrógeno pode apresentar um papel importante na percepção sensitiva (Sessle, 2000). Da mesma forma, houve aumento dos limiares térmicos (frio e calor) com a idade $(p<0,001)$, além de dormência e disestesias terem sido mais freqüentes. Esse dado também é compatível com observações anteriores, que apontam para uma perda sensitiva com a idade (Kenshalo, 1986). Por outro lado, quanto maior a altura, maiores os limiares de calor $(p=0,023)$ e dolorosos de profundidade $(p=0,035)$. As razões para isto são desconhecidas e merecem investigação futura.

\subsection{Avaliação de sensibilidade e correlações com a dor orofacial, queixas de boca seca e fluxo salivar}

Entre os objetivos deste trabalho, fazia parte a investigação de associações e correlações da avaliação de sensibilidade com as características de dor e de boca seca, através dos dados coletados da Amostra 2. Tendo sido incluídos doentes consecutivos durante o período de avaliação, houve variação nos tipos de queixas, diagnósticos, períodos de dor e outras características como fatores de melhora. Mais da metade dos doentes apresentavam dor diária $(55,3 \%)$, e o estresse emocional foi um fator importante de piora da dor $(17,1 \%)$, o que mostra intenso sofrimento e modulação emocional nesses indivíduos (Castro et al., 2008; Castro et al., 
2009). Aspectos afetivos são importantes porque se sabe que a percepção sensitiva depende da atenção, e que fatores emocionais também podem modulá-la, independentemente da sensibilização central que ocorre nas vias de dor durante a cronificação (Kandel, 2003). Houve também associação do tempo frio como fator de piora em $13 \%$, de alimentos com paladar característico como condimentados e ácidos como provocadores de dor, ou ainda o barulho como fator de piora em um doente com NPT, o que reforça a interação sensitiva que ocorre, e que pode gerar desencadeamento da dor através de sensações térmicas ou gustativas variadas (Kandel et al., 2003).

Dor crônica afeta principalmente mulheres e indivíduos na meiaidade (Teixeira et al., 1994; Teixeira, 1995), tendendo a aumentar sua prevalência com o envelhecimento (Teixeira et al., 1993; Siqueira e Teixeira, 2001), o que foi observado nesta amostra. Sessenta e três porcento dos doentes com dor crônica eram mulheres, e a média de idade foi de 56,70 anos. As mulheres apresentaram mais dor, maior incômodo de mastigação e também mais dormência e disestesias $(p<0,001)$. Os motivos pelos quais as mulheres são mais afetadas ainda não foram totalmente elucidados, porém sabe-se que, além das diferenças sócio-culturais entre homens e mulheres, hormônios femininos como o estrógeno podem estar envolvidos na modulação da atividade de receptores de glutamato (excitatórios) e de opióides (inibitórios) (Kaziyama et al, 2008; Kaziyama et al, 2009), o que foi observado em estudos investigando a dor orofacial (Sessle, 2000). É provável que a idade como fator de risco esteja relacionada com a cronificação que acontece ao longo do tempo, com o desgaste músculo- 
esquelético, e devido à exposição a outros fatores de risco, entre outros (IASP, 2006).

A proporção das doenças aqui estudadas corresponde ao esperado em um ambulatório de dor orofacial com foco na dor neuropática, em que a NIT é a mais comumente encontrada, afetando 155:100.000 habitantes em diversos países (Katusic et al., 1990), porém sabe-se que as dores mais comuns na população em geral neste segmento corpóreo são as odontogênicas, seguidas das dores músculo-esqueléticas (Neste estudo, 3,3\% dos doentes apenas apresentavam DTM como diagnóstico primário) (Siqueira e Ching, 1997; Siqueira e Teixeira, 2001). A dor neuropática é caracterizada por comprometimento das vias nervosas periféricas e centrais, e assim anormalidades sensitivas eram de fato esperadas nesses doentes (Teixeira, 1995; Teixeira et al., 2006). Entre as duas amostras, houve diferenças de idades, gênero e área afetada (lado e ramo), porém quando separados em subgrupos de doentes e comparados de acordo com os diagnósticos, apenas permaneceram as diferenças de gênero em NIT $(p=0,023)$, sendo que havia mais mulheres na amostra 2 , e o lado afetado em NPH,que foi mais à direita na amostra $1(p=0,015)$ (Tabela 4). Esses dados podem em parte justificar as diferenças encontradas nas variáveis de sensibilidade entre as duas amostras.

As características dos doentes aqui avaliados, de acordo com o diagnóstico, corresponderam ao esperado pela literatura internacional: na NIT, houve alta prevalência de dor em choque, unilateral, mais à direita, principalmente nos ramos maxilar e mandibular, com alta intensidade $(8,39$ 
pela EVA), aliviada por medicamentos ou repouso total e isolamento, e fatores de piora relacionados à zona de gatilho (Teixeira, 1984; Katusic et al., 1990; Teixeira, 1998; Teixeira et al., 2006); na NPH, dor em queimação $(50,0 \%)$, principalmente no ramo oftálmico do nervo trigêmeo, de alta intensidade (8,5 pela EVA) (Teixeira e Okada, 1999; Peterson e Rowbotham, 2010); na SAB, dor intraoral do tipo queimação $(75,0 \%)$ ou ardor $(p<0,001)$ (Grushka e Sessle, 1988; Nasri et al., 2007); na NPT, descritores característicos de dor neuropática (choque e pontadas em 60,0\%) e dormência associada (20,0\%), associada à lesão nervosa (Forssell et al., 2007), o mesmo observado nos dois doentes com SW; na DFIP, houve alta freqüência do descritor latejante $(75,0 \%)$; os doentes com fibromialgia apresentaram ampla variedade de descritores, dor generalizada $(p=0,008)$, alterações de sono em $87,5 \%$, muitos fatores de piora $(87,5 \%)$ e alta intensidade (9,0 pela EVA) (Forssell et al., 2007); e, por fim, na DTM, caracterizada por dor músculo-esquelética mastigatória, os descritores mais freqüentes foram latejante $(81,8 \%)$ e peso $(26,4 \%)$, com piora à função $(45,5 \%)$ mas melhora com massagem $(18,2 \%)$, assim como nos dois doentes com CC, também de caráter músculo-esquelético (Siqueira e Teixeira, 2001). Também foram compatíveis com amostras anteriores as morbidades associadas, sendo a HAS a mais comum $(40,7 \%)$, e depressão esteve presente em $9,8 \%$ dos doentes (maior em fibromialgia e DFIP, $50,0 \%)$

De uma forma geral, houve alta freqüência nessa amostra de fatores que caracterizam a cronificação da dor, como alta prevalência de 
cefaléia $(43,1 \%)$ e de dor generalizada $(43,1 \%)$ e alterações de sono $(59,3 \%)$. Na presença de cefaléia, houve mais descritores da dor $(p=0,005)$, maior intensidade de dor $(p<0,001)$ e os limiares térmicos (calor e frio) foram maiores, o que caracteriza sensibilização central. De fato, diversas variáveis relacionadas à intensidade e duração de dor se correlacionaram com maiores limiares sensitivos, inclusive gustativos.

Não houve diferença entre os grupos com relação às características dentárias, porém doentes com SAB tiveram mais ressecamento e língua fissurada, o que contribui para o ardor bucal. Sabe-se que anormalidades oclusais podem contribuir para a DTM em cerca de $10 \%$ dos casos (Seligman e Pullinger, 1993) e que infecções orais podem ser causa de dor secundária nos doentes com dor orofacial (Fabri et al., 2009; Siqueira et al., 2010). Nessa amostra, a presença de infecção oral se correlacionou com menores limiares de dor de profundidade $(p=0,016)$.

Queixas de boca seca foram mais freqüentes nos doentes do que nos controles $(p=0,032)$, e alguns dos fatores relacionados, como dificuldade em falar, boca seca durante as refeições, dificuldade no uso de próteses, evitar alimentos e utilização de balas e chicletes foram mais comuns em alguns subgrupos de dor, como DFIP, SAB e NPT. É possível que essas queixas tenham sido mais prevalentes nesses grupos pelo caráter intraoral da condição que eles apresentam, em comparação com os outros doentes. As variáveis de boca seca, cefaléia, intensidade de dor, de dormência e de disestesia estiveram relacionadas com anormalidades sensitivas como redução de paladar $(p=0,028)$, paladar alterado $(p=0,003)$, gosto fantasma 
$(p<0,001)$ e queimação oral $(p<0,001)$. Quanto mais queixas subjetivas de paladar alterado ou gosto fantasma, maiores foram os limiares dolorosos de profundidade $(p=0,002)$.

Não houve diferença estatística entre os grupos quanto ao fluxo salivar, porém em geral este foi menor nos doentes do que nos controles; as causas para isso pode envolver o uso de medicamentos crônicos no caso de grande parte dessa amostra, ou ainda constituir anormalidade neurovegetativa secundária à dor crônica (Siviero et al., 2010).

Algumas das limitações neste estudo foram a heterogeneicidade da amostra estudada, o que resultou em subgrupos pequenos que não permitiram análise estatística adequada e a impossibilidade de validação da metodologia por serem amostras distintas. Optou-se por manter dessa forma uma vez que é compatível aos objetivos de apresentação da metodologia e das características desses doentes de uma forma geral. Além disso, muitos doentes faziam uso de medicamentos que têm ação no sistema nervoso e podem alterar a percepção sensitiva, o que pode ser causa parcial dos achados observados.

Os dados aqui obtidos foram em parte publicados e refletem a evolução do laboratório de sensibilidade desde a sua concepção ao seu estabelecimento nos dias atuais, contando com metodologias variadas que permitem a investigação como um todo da sensibilidade orofacial e que aqui foram apresentadas. 


\section{CONCLUSÕES}

Através deste estudo, conclui-se que:

1. A metodologia desenvolvida pela Divisão de Neurocirurgia Funcional do Instituto de Psiquiatria do Hospital das Clínicas e Departamento de Neurologia da FMUSP foi uma ferramenta que contribuiu para a avaliação da sensibilidade somestésica, gustativa e olfativa através dos protocolos internacionais de TSQ para a região orofacial;

2. Doentes com NPH e SAB apresentaram diferenças estatísticas maiores do que outros os doentes quando comparados aos controles nas avaliações térmica (frio e calor), mecânica táctil e dolorosa de profundidade, principalmente na região inervada pelo ramo oftálmico do nervo trigêmeo; os doentes com NIT apresentaram limiares maiores tácteis de superfície no ramo mandibular e doentes com ND apresentaram os menores limiares de forma geral; os limiares gustativos foram maiores nos grupos de doentes do que nos controles, exceto no grupo com fibromialgia, que apresentou limiares maiores; não houve diferença quanto aos limiares olfativos;

3. Intensidade de dor, presença de cefaléia e queixas de boca seca associaram-se às seguintes anormalidades sensitivas: redução de paladar, paladar alterado, gosto fantasma e 
queimação oral. Quanto mais queixas subjetivas de paladar alterado ou gosto fantasma, maiores foram os limiares dolorosos de profundidade. Não houve diferença estatística no fluxo salivar. 


\section{REFERÊNCIAS}

Accolla R, Bathellier B, Petersen CC, Carleton A. Differential spatial representation of taste modalities in the rat gustatory cortex. $J$ neurosci. 2007;27(6):1396-404.

Akabas MH. Mechanisms of chemosensory transduction in taste cells. Int Rev neurobiol. 1990;32:241-79.

Alkon DL, Akaike T, Harrigan J. Interaction of chemosensory, visual, and statocyst pathways in Hermissenda crassicornis. J Gen Physiol. 1978 Feb;71(2):177-94.

Alvarez FK. Neuralgia pós-herpética trigeminal: avaliações clínica e de sensibilidade orofacial. [Dissertação] São Paulo: Faculdade de Medicina Universidade de São Paulo; 2008.

Alvarez FK, Siqueira SRDT, Okada M, Teixeira MJ, Siqueira JTT. Evaluation of the sensation in patients with trigeminal post herpetic neuralgia. J Oral Pathol. 2007;36, 347-50.

Anbar M, Gratt BM. Role of nitric oxide in the physiopathology of pain. $J$ Pain Symptom Manage. 1997;14(4):225-54.

Anseloni VC, Ren K, Dubner R, Ennis M. A brainstem substrate for analgesia elicited by intraoral sucrose. Neuroscience. 2005;133(1):231-43.

Apkarian AV, Stea RA, Bolanowski SJ. Heat-induced pain diminishes vibrotactile perception: a touch gate. Somatosens Mot Res. 1994;11(3):259-67. 
Arap A, Siqueira SRDT, Silva CB, Teixeira MJ, Siqueira JTT. Trigeminal pain and quantitative sensory testing in painful peripheral diabetic neuropathy. Arch Oral Biol, 2010;55:486-93.

Armstrong DM. Three types of consciousness. Ciba Found Symp. 1979; 69:235-53.

Axel R. The molecular logic of smell. Sci Am. 1995; 273:154-9.

Bajec MR, Pickering GJ. Thermal taste, PROP responsiveness, and perception of oral sensations. Physiol Behav. 2008;95(4):581-90.

Bartoshuk LM, Beauchamp GK. Chemical senses. Annu RTev Psychol $1994 ; 45: 419-49$.

Bartoshuk LM. Clinical psychophysics of taste. Gerodontics, 1988;4(5):249-55.

Basbaum Al e Jessell TM. A percepção da dor. In: Kandel ER, Schwartz JH, Jessell TM. Princípios da Neurociência. $4^{\mathrm{a}}$ Ed. Rio de Janeiro: Manole. 2003. p.473-91.

Baumann TK, Simone DA, Shain CN, LaMotte RH. Neurogenic hyperalgesia: the search for the primary cutaneous afferent fibers that contribute to capsaicin-induced pain and hyperalgesia. $J$ Neurophysiol, 1991;66(1):212-27.

Bellieni CV, Buonocore G, Nenci A, Franci N, Cordelli DM, Bagnoli F. Sensorial saturation: an effective analgesic tool for heel-prick in preterm infants: a prospective randomized trial. Biol Neonate. $2001 ; 80(1): 15-8$.

Bennett MR. Development of the concept of mind. Aust N Z J Psychiatry. 2007;41(12):943-56. 
Berridge KC, Fentress JC. Trigeminal-taste interaction in palatability processing. Science. 1985:228(4700):747-50.

Bicchi A, Scilingo EP, Ricciardi E, Pietrini P. Tactile flow explains haptic counterparts of common visual illusions. Brain Res Bull. 2008;75(6):737-41.

Bondì $\mathrm{M}$, Bondì $\mathrm{M}$. The role of synaptic junctions in the identification of human consciousness. Rev Biol. 1998;91(2):329-34.

Bonica JJ. The management of pain. Lea \& Febiger, Philadelphia, 1953. $1076 p$.

Boly $M$, Faymonville ME, Schnakers $C$, Peigneux $P$, Lambermont $B$, Phillips $C$, Lancellotti $P$, Luxen A, Lamy M, Moonen $G$, Maquet $P$, Laureys $S$. Perception of pain in the minimally conscious state with PET activation: an observational study. Lancet Neurol. 2008;7(11):1013-20.

Bradley RM, Grabauskas G. Neural circuits for taste. Excitation, inhibition, and synaptic plasticity in the rostral gustatory zone of the nucleus of the solitary tract. Ann N Y Acad Sci. 1998;855:467-74.

Bradley RM, King MS, Wang L, Shu X. Neurotransmitter and neuromodulator activity in the gustatory zone of the nucleus tractus solitarius. Chem Senses. 1996;21(3):377-85.

Brand P. Pain--it's all in your head: a philosophical essay. J Hand Ther. 1997;10(2):59-63.

Brandt $T$, Bartenstein $P$, Janek $A$, Dieterich $M$. Reciprocal inhibitory visual-vestibular interaction. Visual motion stimulation deactivates the parieto-insular vestibular cortex. Brain. 1998;121( Pt 9):1749-58. 
Brazolotto,TM. Prevalência de doenças orais e de disfunção mandibular em pacientes submetidos à craniotomia pterional. [Dissertação] São Paulo: Faculdade de Medicina, Universidade de São Paulo; 2011.

Britton NF, Skevington SM. A mathematical model of the gate control theory of pain. J Theor Biol. 1989;137(1):91-105.

Buck LB. Olfação e gustação: os sentidos químicos. In: Kandel ER, Schwartz JH, Jessell TM. Princípios da Neurociência. $4^{a}$ Ed. Rio de Janeiro: Manole. 2003. p.625-47.

Buzalaf MAR, Ramires I, Maria AG, Peres JRB, Lauris JRP. Conhecimento dos médicos pediatras e odontopediatras de Bauru e Marília a respeito de flúor. Ciênc. saúde coletiva. Rio de Janeiro. 2006;11(1):201-9.

Castro AR, Siqueira SRDT, Perissinotti DM, Teixeira MJ, Siqueira JT. Emotional aspects of chronic orofacial pain and surgical treatment. Int J Surg,2009;3:196-9.

Castro AR, Siqueira SRDT, Perissinotti DMN, Siqueira JTT. Psychological evaluation and cope with trigeminal neuralgia and temporomandibular disorders. Arq neuropsiquiatr, 2008;66:716-9.

Cenquizca LA, Swanson LW. Spatial organization of direct hippocampal field CA1 axonal projections to the rest of the cerebral cortex. Brain Res Rev. 2007; 56(1):1-26.

Cerf-Ducastel B, Murphy C. fMRI activation in response to odorants orally delivered in aqueous solutions. Chem Senses. 2001;26(6):625-37.

Chen JT, Fagan MJ, Diaz JA, Reinert SE. Is treating chronic pain torture? Internal medicine residents' experience with patients with chronic nonmalignant pain. Teach Learn Med. 2007;19(2):101-5. 
Chen JY, Di Lorenzo PM. Responses to binary taste mixtures in the nucleus of the solitary tract: neural coding with firing rate. $J$ neurophysiol, 2008;99(5): 2144-57.

Cho YK, Li CS. Gustatory neural circuity in the hamster brain stem. J neurophysiol, 2008; 100(2): 1007-19.

Coelho CMP, Sousa YTCS, Daré AMZ, Pereira ACCI, Cardoso CM. Implicações clínicas da Xerostomia: Abordagens sobre o diagnóstico e tratamento. Rev Assoc Paul Cir Dent, 2002;56(4):295-8.

Corey DP, Roper SD (eds). Sensory transduction: society of general physiologists, $45^{\text {th }}$ annual symposium. Marine Biological Laboratory, Woods Hole, Massachusetts. New York: Rockefeller Univ. Press, 1992.

Croft P, Rilgby AS, Boswell R, Schollum J, Silmam A. The Prevalence of Chronic widespread Pain in the General Population. J Rheumatol. 1993; 20(4):710-3.

Crossman AR e Neary D. Neuranatomia. $2^{\mathrm{a}}$ Ed. Rio de Janeiro: Guanabara Koogan. 2002.

Dallel R, Ricard O, Raboisson P. Organization of parabrachial projections from the spinal trigeminal nucleus oralis: an anterograde tracing study in the rat. J Comp Neurol. 2004; 470(2):181-91.

Dellaroza MSG, Pimenta CAM, Matsuo T. Prevalência e caracterização da dor crônica em idosos não institucionalizados. Cad Saúde Pública, 2007; 23(5): 1151-60.

de Leeuw R. Orofacial Pain. Guidelenes for Assessment, Diagnosis, and Management. $4^{\text {th }}$ Ed. Quintessence 2008. 316p. 
Doreyat J, Jaafar N. Impact of orofacial pain and discomfort in 16-17 yrsold children in Johor. J Dent Res, 1998;77:1350. [Abstract].

Doty RL. The olfactory system and its disorders. Semin Neurol, 2009;29(1):74-81.

Dubner R, Ruda MA. Activity-dependent neuronal plasticity following tissue injury and inflammation. Trends in Neurosci, 1992;15:96-103.

Dudel J. General sensory physiology. In: RF Schmidt, G Thews (eds), MA Biederman-Thorsen (transl). Human Physiology, Berlin: Springer. 1983. p.177-92.

Dworkin SF, LeResche L. Research diagnostic criteria for temporomandibular disorders: review, criteria, examinations and specifications, critique. J Craniomand Disord. 1992;6(4):301-55.

Eckley CA, Costa HO. Rev. Bras. Estudo da concentração salivar do fator de crescimento epidérmico em indivíduos com laringite crônica por refluxo laringofaríngeo. Rev Bras Otorrinolaringol, 2003;69(5):590-97.

Eliav E, Kamran B, Schaham R, Czerninski R, Gracely RH, Benoliel R. Evidence of chorda tympani dysfunction in patients with burning mouth syndrome. J Am Dent Assoc, 2007;138(5):628-33.

Eliav E, Gracely RH, Nahlieli O, Benoliel R. Quantitative sensory testing in trigeminal nerve damage assessment. J Orofac Pain, 2004;18:33944.

Eram M, Michel WC. Heterogeneous distribution of taste cells in facial and vagal nerve-innervated taste buds. Neuroscience, 2006;138(1):339-50. 
Etoh S, Kawahira K, Ogata A, Shimodozono M, Tanaka N. Relationship between dysgeusia and dysesthesia in stroke patients. Int $J$ Neurosci, 2008;118(1):137-47.

Fabri GM, Siqueira SRDT, Simione C, Nasri C, Teixeira MJ, Siqueira JT. Refractory craniofacial pain: is there a role of periodontal disease as a comorbidity? Arq Neuropsiquiatr, 2009;67(2B):474-9.

Favorov O, Kelly DG. Miunicolumnar organization within somatosensory cortical segregates. II. Emergent functional properties. Cereb Cortex, 1994;4:428-42.

Femiano F, Lanza A, Buonaiuto C, Gombos F, Cirillo N. Burning mouth disorder (BMD) and taste: a hypothesis. Med Oral Patol Oral Cir Bucal, 2008; 13(8):E470-4.

Ferreira KASL, Kimura M, Teixeira MJ. Impact of adequacy of pain treatment on quality of life of cancer patients. In: $13^{\text {th }}$ Annual Conference of the International Society for Quality of Life Research. Portugal: Quality of Life Research; 2006. p. A-90.

Ferreira KASL, Siqueira SRDT, Teixeira MJ. Características demográficas, da dor e do tratamento dos pacientes atendidos no Centro Multidisciplinar de Dor. Cadernos Saúde Pública, 2008;XVI(3):459-70.

Formaker BK, Frank ME. Taste function in patients with oral burning. Chem Senses, 2000;25(5):575-81.

Fortner BV, Demarco G, Irving G, Ashley J, Keppler G, Chavez J, Munk J. Description and predictors of direct and indirect costs of pain reported by cancer patients. J Pain Symptom Manage, 2003;25(1):9-18. 
Forssell H, Jääskeläinen S, Tenovuo O, Hinkka S. Sensory dysfunction in burning mouth syndrome. Pain, 2002;99(1-2):41-7.

Forssell H, Tenovuo O, Silvoniemi P, Jääskeläinen SK (2007). Differences and similarities between atypical facial pain and trigeminal neuropathic pain. Neurology, 2007;69:1451-9.

Frasnelli J, Heilmann S, Hummel T. Responsiveness of human nasal mucosa to trigeminal stimuli depends on the site of stimulation. Neurosci Lett, 2004;362(1):65-9.

Frasnelli J, Hummel T. Interactions between the chemical senses: trigeminal function in patients with olfactory loss. Int J Psychophysiol, 2007;65(3):177-81.

Frasnelli J, Schuster B, Hummel T. Interactions between olfaction and the trigeminal system: what can be learned from olfactory loss. Cereb Cortex. 2007;17(10):2268-75.

Frasnelli J, Schuster B, Hummel T. Subjects with congenital anosmia have larger peripheral but similar central trigeminal responses. Cereb Cortex. 2007;17(2):370-7.

Ganchrow D, Erickson RP. Taste quality and intensity: lessons from the Morrison technique. Physiol Behav. 2000;69(1-2):121-33.

Gardner EP, Hërnäläinen HA, Palmer Cl, Warren S. Touching the outside world: representation of motion and direction within primary somatosensory cortex. In: JS Lund (ed). Sensory processing in mammalian brain: neural substrates and experimental strategies. New York: Oxford Univ. Press. 1989, p.49-66. 
Gardner EP e Kandel ER. Tato. In: Kandel ER, Schwartz JH, Jessell TM. Princípios da Neurociência. $4^{a}$ ed. Rio de Janeiro: Manole. 2003. p.451-71.

Gardner EP e Martin JH. Codificação da informação sensória. In: Kandel ER, Schwartz JH, Jessell TM. Princípios da Neurociência. $4^{\mathrm{a}}$ ed. Rio de Janeiro: Manole. 2003. p.411-29.

Geran LC, Spector AC. Sodium taste detectability in rats is independent of anion size: the psychophysical characteristics of the transcellular sodium taste transduction pathway. Behav Neurosci. 2000;114(6):1229-38.

Goes PSA. The prevalence, severity and impact of dental pain in Brazilian schoolchildren and their families. [Doutorado]. London (UK): University of London; 2001.

Gottlieb G. Conception of prenatal behavior. In: Aronson LR et al., eds. Development and evolution of behavior. San Francisco: WH Freeman, 1970. p. 111-137.

Grabauskas G, Bradley RM. Synaptic interactions due to convergent input from gustatory afferent fibers in the rostral nucleus of the solitary tract. J Neurophysiol. 1996;76(5):2919-27.

Grill HJ, Schwartz GJ, Traves J. The contribution of gustatory nerve input to oral motor behavior and fluid intake-based preference: I. Effects of chorda tympani or glossopharyngeal nerve section in the rat. Brain Res. 1991;573: 95-104.

Grushka M, Ching V, Epstein J. Burning mouth syndrome. Adv Otorhinolaryngol. 2006; 3:278-87. 
Grushka M, Epstein JB, Gorsky M. Burning mouth syndrome and other oral sensory disorders: a unifying hypothesis. Pain Res Manag. 2003;8(3):133-5.

Grushka M, Sessle B. Taste dysfunction in burning mouth syndrome. Gerodontics. 1988;4(5):256-8.

Hakeberg M, Berggren U, Hägglin C, Ahlqwist M. Reported burning mouth symptoms among middle-aged and elderly women. Eur J Oral Sci. 1997; 105(6):539-43.

Handwerker HO. [From Descartes to fMRI. Pain theories and pain concepts] Schmerz. 2007;21(4):307-10, 312-7.

Heckmann JG, Lang CJ. Neurological causes of taste disorders. Adv Otorhinolaryngol. 2006;63:255-64.

Henderson JM. Peripheral nerve stimulation for chronic pain. Curr Pain Headache Rep. 2008;12(1):28-31.

Hendricks SJ, Sollars SI, Hill DL. Injury-induced functional plasticity in the peripheral gustatory system. J neurosci. 2002;22(19):8607-13.

Hensel H. Cutaneous thermoreceptors. In: A Iggo (ed). Handbook of sensory physiology. Vol 2, Somatosensory system. Berlin: SpringerVerlag. 1973; p.79-110.

Higgens JD, Tursky B, Schwartz GE. Shock-elicited pain and its reduction by concurrent tactile stimulation. Science. 1971;172(985):866-7.

Holland GR. Experimental trigeminal nerve injury. Crit Rev Oral Biol Med. 1996;7(3):237-58. 
Hollshwandner $\mathrm{CH}$, Brenman HS, Friedman $\mathrm{MH}$. Role of afferent sensors in the initiation of swallowing in man. J Dent Res. 1975;54(1):83-8.

Hospedales T, Vijayakumar S. Multisensory oddity detection as bayesian inference. PLoS ONE. 2009;4(1):e4205.

Hummel T, Livermore A. Intranasal chemosensory function of the trigeminal nerve and aspects of its relation to olfaction. Int Arch Occup Environ Health. 2002;75(5):305-13.

International Association for the study of pain (IASP): Subcommittee on Taxonomy. Classification of chronic pain. Descriptions of chronic pain syndromes and definitions of pain terms. Pain Suppl. 1986;3:S1-226.

International Headache Society Classification Subcommittee, International classification of headache disorders, $2^{\text {nd }}$ ed. Cephalalgia. 2004;24(1), 1-160.

Jääskeläinen SK. Clinical neurophysiology and quantitative sensory testing in the investigation of orofacial pain and sensory function. $J$ Orofac Pain. 2004;18(2):85-107.

Jahn RG, Dunne BJ. Sensors, filters, and the source of reality. Explore (NY). 2007;3(3):326-37.

James FR, Large RG, Bushnell JA, Wells JE. Epidemiology of pain in New Zealand. Pain. 1991;44(3):279-83.

Johnson EO, Babis GC, Soultanis KC, Soucacos PN. Functional neuroanatomy of proprioception. J Surg Orthop Adv. 2008;17(3):15964. 
Kandel ER. O sistema nervoso e o comportamento. In: Kandel ER, Schwartz JH, Jessell TM. Princípios da Neurociência. $4^{a}$ ed. Rio de Janeiro: Manole. 2003. p.5-18.

Kandel ER, Schwartz JH, Jessell TM. Princípios da Neurociência. $4^{a}$ ed. Rio de Janeiro: Manole. 2003. p1430.

Katusic S, Beard CM, Bergstralh E, Kurland LT. Incidence and clinical features of trigeminal neuralgia, Rochester, Minnesota, 1945-1984. Ann Neurol. 1990;27(1):89-95.

Kaziyama HH, Yeng LT, Teixeira MJ, Okada M. In: Teixeira MJ, Yeng LT, Kaziyama HHS. Dor. Síndrome Dolorosa Miofascial e Dor Músculo esquelética. São Paulo: Ed. Roca, 2008. p. 119-34.

Kaziyama HHS, Yeng LT, Teixeira MJ, Okada M. In: Neto AO, Costas CMC, Siqueira JTT, Teixeira MJ. Dor. Princípios e Práticas: Síndrome Fibromiálgica. São Paulo: Ed. Artmed, 2009, p. 464-90.

Kenshalo DR, Somesthetic Sensitivity In Young and Elderly HumanS. J Gerontology, 1986;41(6):732-42.

King CT, Travers SP, Rowland NE, Garcea M, Spector AC. Glossopharyngeal nerve transaction eliminates quinine-stimulated foslike immunoreactivity in the nucleus of the solitary tract: implications for a functional topography of gustatory nerve input in rats. J neurosci. 1999;19:3107-21.

King CT, Garcea M, Spector AC. Glossopharyngeal nerve regeneration is essential for the complete recovery of quinine-stimulated oromotor rejection behaviors and central patterns of neuronal activity in the nucleus of the solitary tract in the rat. J neurosci. 2000;20:8426-34. 
Kohjitani A, Miyawaki T, Kasuya K, Shimada M. Sympathetic activitymediated neuropathic facial pain following simple tooth extraction: a case report. Cranio. 2002;20(2):135-8.

Kopka SL, Geran LC, Spector AC. Functional status of the regenerated chorda tympani nerve as assessed in a salt taste discrimination task. Am J Physiol Regul Integr Comp Physiol. 2000;278:R720-31.

Korn GP, Pupo DB, Quedas A, Filho IB. Correlação entre o grau de xerostomia e o resultado da sialometria em pacientes com Síndrome de Sjögren. Rev Bras Otorrinolaringol. 2002;68(5):

Krout KE, Loewy AD. Parabrachial nucleus projections to midline and intralaminar thalamic nuclei of the rat. J Comp Neurol. 2000; 428(3):475-94.

Kutyna FA, Bernard R. Effects of antidromic activity in gustatory nerve fibers on taste disc cells of the frog tongue. J comp Physiol. 1977;118(3):291-306.

Lam NP, Donoff RB, Kaban LB, Dodson TB. Patient satisfaction after trigeminal nerve repair. Oral Surg Oral Med Oral Pathol Oral Radiol Endod. 2003;95(5):538-43.

Lamey PJ. Burning mouth syndrome. Dermatol Clin. 1996;14(2):339-54.

Lang E, Kaltenhäuser $M$, Seidler S, Mattenklodt $P$, Neundörfer B. Persistent idiopathic facial pain exists independent of somatosensory input from the painful region: findings from quantitative sensory functions and somatotopy of the primary somatosensory cortex. Pain. 2005;118:80-91.

Lenggenhager B, Mouthon M, Blanke O. Spatial aspects of bodily selfconsciousness. Conscious Cogn. 2009;18(1):110-7. 
Liberati D, Bedarida L, Brandazza P, Cerutti S. A model for the corticocortical neural interaction in multisensory-evoked potentials. Biomed Eng IEEE Trans. 1991;38(9):879-90.

List T, Leijon G, Svensson P. Somatosensory abnormalities in atypical odontalgia: A case-control study. Pain. 2008;139(2):333-41.

Livermore A, Hummel T. The influence of training on chemosensory event-related potentials and interactions between the olfactory and trigeminal systems. Chem Senses. 2004;29(1):41-51.

Luft AR, Manto MU, Ben Taib NO. Modulation of motor cortex excitability by sustained peripheral stimulation: the interaction between the motor cortex and the cerebellum. Cerebellum. 2005;4(2):90-6.

Lundy RF Jr, Norgren R. Pontine gustatory activity is altered by electrical stimulation in the central nucleus of the amygdale. $J$ neurophysiol. $2001 ; 85(2): 770-83$.

Mao L, Cho YK, Li CS. Modulation of activity of gustatory neurons in the hamster parabrachial nuclei by electrical stimulation of the ventroposteromedial nucleus of the thalamus. Am J Physiol Regul Integr Comp Physiol. 2008;294(5):R1461-73.

Manley CH. Psychophysiological effect of odor. Crit Rev Food Sci Nutr. 1993;33(1):57-62.

McDermott AM, Toelle TR, Rowbothan DJ, Schaefer CP, Dukes EM. The burden of neuropathic pain: results from a cross-sectional survey. Eur J Pain. 2006;10(2):127-35.

McMahon SB, Koltzenburg M. Novel classes of nociceptors: beyond Sherrington. Trends in Neurosci. 1990;13:199-201. 
Melzack R, Wall PD. On the nature of cutaneous sensory mechanisms. Brain. 1962;85:331-56.

Melzack R, Wall PD. Pain mechanisms: a new theory. Science. 1965;150(699):971-9.

Melzack R. From the gate to the neuromatrix. Pain. 1999;Sup 6:S121-6.

Merskey H, Bogduk N: Classification of chronic pain. Seattle, WA: IASP Press, 1994.

Monroe S, Di Lorenzo PM. Taste responses in neurons in the nucleus of the solitary tract that do and do not project to the parabrachial pons. $J$ neurophysiol. 1995;74(1):249-57.

Mountcastle VB, Talbot $\mathrm{WH}$, Kronhuber $\mathrm{HH}$. The neural transformation of mechanical stimuli delivered to the monkey's hand. In: AVS de Reuck, J Knight (eds). Ciba Foundation Symposium: Touch, Heat and Pain, 1966; p.325-51.

Mountcastle VB. The columnar organization of the neocortex. Brain. 1997; 120:702-22.

Mountcastle VB. The parietal system and some higher brain functions. Cereb Cortex. 1995;5:377-90.

Nakao Y, Itoh Y, Kuang TY, Cook M, Jehle J, Sokoloff L. Effects of anesthesia on functional activation of cerebral blood flow and metabolism. Proc Natl Acad Sci USA. 2001;98(13):7593-8.

Nasri C, Teixeira MJ, Okada M, Formigoni G, Heir G, Siqueira JT. Burning mouth complaints: clinical characteristics of a Brazilian sample. Clinics. 2007;62(5):561-6. 
Nasri C, Teixeira MJ, Siqueira JTT. Ardência bucal: avaliação de uma amostra clínica. Rev Simbidor. 2000;1:75-82.

Nickel R, Raspe HH. Chronic pain: epidemiology and health care utilization. Nervenarzt. 2001;72(12):897-906.

Niemi $M$, Laaksonen JP, Forssell $H$, Jääskeläinen $S$, Aaltonen $O$, Happonen RP (2009). Acoustic and neurophysiologic observations related to lingual nerve impairment. Int J Oral Maxillofac Surg. 38:75865.

Nóbrega JCM, Siqueira SR, Siqueira JT, Teixeira MJ. Differential diagnosis in atypical facial pain: a clinical study. Arq neuropsiquiatr. 2007;65:256-61.

Ohmoto M, Matsumoto I, Yasuoka A, Yoshihara Y, Abe K. Genetic tracing of the gustatory and trigeminal neural pathways originating from T1R3expressing taste receptor cells and solitary chemoreceptor cells. Mol Cell Neurosci. 2008;38(4):505-17.

Okeson JP. Orofacial pain: guidelines for assessment, diagnosis and management. Chicago: Quintessence, 1996.

Oliveira SB, de Siqueira SR, Sanvovski AR, do Amaral LM, de Siqueira JT. Temporomandibular Disorder in Brazilian patients: a preliminary study. J Clin Psychol Med Settings, 2008;15(4):338-43.

Onoda K, Kobayakawa T, Ikeda M, Saito S, Kida A. Laterality of human primary gustatory cortex studied by MEG. Chem Senses. 2005;30(8):657-66. 
Petersen P, Gao C, Rossel P, Qvist P, Arendt-Nielsen L, Gregersen H, dRewes AM. Sensory and biomechanical responses to distension of the normal human rectum and sigmoid colon. Digestion. 2001;64(3):191-9.

Petersen KL, Rowbotham MC. Natural history of sensory function after herpes zoster. Pain. 2010;150(1):83-92.

Pigg M, Baad-Hansen L, Svensson P, Drangsholt M, List T. Reliability of intraoral quantitative sensory testing (QST). Pain. 2009;148(2):220-6

Prado EB. Dor Facial Atípica [dissertação]. São Paulo: Faculdade de Medicina, Universidade de São Paulo; 2002.

Pupo DB, Bussoloti $\mathrm{F}^{\circ}$ I, Liquidato BM, Korn GP. Proposta de um método prático de sialometria. Rev Bras Otorrinolaringol. 2002;68(2):219-22.

Radin D. Testing nonlocal observation as a source of intuitive knowledge. Explore (NY). 2008;4(1):25-35.

Reilly S. The role of the gustatory thalamus in taste-guided behavior. Neurosci Biobehav Rev. 1998;22(6):883-901.

Renehan WE, Crissman RS, Jacquin MF. Primary afferent plasticity following partial denervation of the trigeminal brainstem nuclear complex in the postnatal rat. J neurosci. 1994;14(2):721-39.

Consensus statement: Report and recommendation of the San Antonio Conference on Diabetic Neuropathy. American Diabetes Association American Academy of Neurology. Diabetes Care. 1988;37:1000-4.

Rivera V, Hernández D, Rojas S, Oliver G, Serrano J, Shibayama M, Tsutsumi, Campos R. IgA and IgM anti-Naegleria fowler anti-bodies in human serum and saliva. Can J Microbiol. 2001;47(5):464-6. 
Roitman MF, Bernstein IL. Amiloride-sensitive sodium signals and salt appetite: multiple gustatory pathways. Am J Physiol. 1999;276:R17328.

Ryhammer AM, Laurberg S, Bek KM. Age and anorectal sensibility in normal women. Scan J Gastroenterol. 1997;32(3):278-84.

Sánchez-Juan P, Combarros O. [Gustatory nervous pathway syndromes] Neurologia. 2001;16(6):262-71.

Sardella A, Demarosi F, Barbieri C, Lodi G. An up-to-date view on persistent idiopathic facial pain. Minerva Stomatol. 2009;58(6):289-99.

Savage CW. The measurement of sensation: a critique of perceptual psychophysics. Berkeley: Univ. California Press. 1970.

Sessle BJ. Acute and chronic craniofacial pain: brainstem mechanisms of nociceptive transmission and neuroplasticity, and their clinical correlates. Crit Rev Oral Biol Med. 2000;11(1):57-91.

Shepherd GM. Perspectives on olfactory processing, conscious perception, and orbitofrontal cortex. Ann N Y Acad Sci. 2007;1121:87101.

Sherrington $C$. The integrative action of the nervous system. $2^{\text {nd }}$ ed. New Haven: Yale Univ. Press. 1947.

Simonov PV. Consciousness and the brain. Neurosci Behav Physiol. $1994 ; 24(3): 234-8$.

Siqueira JTT, Ching LH. Dificuldades no diagnóstico diferencial de dores dentárias referidas à face. Conduta clínica e considerações sobre uma amostra. J bras odontol clin. 1997;1(2):11-8. 
Siqueira JTT, Ching LH. Dificuldades no diagnóstico diferencial das dores dentárias referidas à face. Conduta clínica. In: Siqueira JTT, Ching LH, editores. Dor Orofacial/Atm, Bases para o diagnóstico clínico, $2^{\mathrm{a}}$ ed, Curitiba: Maio, 2001.

Siqueira JTT. Dores Dentárias Difusas/Odontalgia Atípica. In: Siqueira JTT, Teixeira MJ, editores. Dor Orofacial Diagnóstico, Terapêutica e Qualidade de Vida. Curitiba: Maio, 2001.

Siqueira JTT, Teixeira MJ. Dor Orofacial - diagnóstico, terapêutica e qualidade de vida. Curitiba: Maio, 2001.

Siqueira SRDT, Siqueira JTT. Neuralgia do trigêmeo: Diagnóstico diferencial com odontalgia. Rev Assoc Paul Cir Dent, 2003;57(5):354-6.

Siqueira SRDT, Teixeira MJ. Neuralgias do Segmento Facial. JBA, 2003; 3(10):101-10.

Siqueira JTT, Ching LH, Nasri C, Siqueira SRDT, Teixeira MJ, Heir G, Valle LBS. Clinical study of patients with persistent orofacial pain. Arq neuropsiquiatr. 2004a;62(4):988-96.

Siqueira SRDT, Nóbrega JCM, Valle LBS, Teixeira MJ, Siqueira JTT. Idiopathic trigeminal neuralgia: Clinical aspects and dental procedures. Oral Surg Oral Med Oral Pathol Oral Radiol Endod, 2004b;98(3):3115.

Siqueira SRDT, Lara C, Nóbrega JCM, Siqueira JTT, Teixeira MJ. Sensitive evaluation of patients with idiopathic trigeminal neuralgia treated with functional neurosurgery. The Pain Clin, 2006a;18(1):8792. 
Siqueira SR, Okada M, Lino AM, Teixeira MJ, Siqueira JT. Proposal for a standardized protocol for the systematic orofacial examination of patients with Hereditary Sensory Radicular Neuropathy. Int Endod J. 2006;39,905-15.

Siqueira SR, Nóbrega JCM, Teixeira MJ, Siqueira JTT. Olfactory threshold increase in trigeminal neuralgia after balloon compression. Clin Neurol Neurosurg. 2006;108:721-5.

Siqueira SRDT, Nóbrega JCM, Teixeira MJ, Siqueira JTT. Frequency of post-operative complications after balloon compression for idiopathic trigeminal neuralgia - prospective study. Oral Surg Oral Med Oral Pathol Oral Radiol Endod, 2006d;102(5):e39-42.

Siqueira SR, da Nóbrega JC, Teixeira MJ,de Siqueira JT. Masticatory problems after balloon compression for trigeminal neuralgia, a longitudinal study. J Oral Rehabil. 2007;34(2):88-96.

Siqueira SRDT, Almansa NK, Teixeira MJ, Siqueira SRDT. Levantamento epidemiológico de dor da Clínica Odontológica do Sesc Santo André, Brasil. Rev DOR, 2008;9(2):1225-33.

Siqueira SRDT. Facial Sensibility, Smell and Taste in Trigeminal Neuropathic Pain. Annual Meeting of the International Association of Dental Research, Miami, EUA, Abril/2009. [Apresentação Oral].

Siqueira SRDT, Alves B, Malpartida HM, Teixeira MJ, Siqueira JT. Abnormal expression of voltage-gated sodium channels Nav1.7, Nav1.3 and Nav1.8 in trigeminal neuralgia. Neuroscience, 2009;164(2):573-7.

Siviero M, Teixeira MJ, Siqueira JTT, Siqueira SRDT. Somesthetic, gustatory, olfactory function and salivary flow in patients with trigeminal neuropathic pain. Oral Dis. 2010;16(5):482-7. 
Siviero M, Teixeira MJ, Siqueira JTT, Siqueira SRDT. Rapid communication: Central Mechanisms in burning mouth syndrome involving the olfactory nerve: preliminary study. Clinics, 2011a. [In press].

Siviero M, Alvarez FK, Okada M, Teixeira MJ, Siqueira JTT, Siqueira SRDT. Facial sensibility of patients with trigeminal neuralgias. Clin Neurol Neurosurg, 2011b. [In press].

Siviero M. Avaliação sensitiva orofacial, gustativa, olfativa e salivar em doentes com neuralgias trigeminais. [Dissertação] Faculdade de Medicina, Universidade de São Paulo. 2011.

Shiau CE, Lwigale PY, Das RM, Wilson SA, Bronner-Fraser M. Robo2Slit1 dependent cell-cell interactions mediate assembly of the trigeminal ganglion. Nat Neurosci. 2008;11(3):269-76.

Shikama Y, Kato T, Nagaoka U, Hosoya T, Katagiri T, Yamaguchi K, Sasaki H. Localization of the gustatory pathway in the human midbrain. Neurosci Lett. 1996;218(3):198-200.

Shipley MT, Geinisman Y. Anatomical evidence for convergence of olfactory, gustatory, and visceral afferent pathways in mouse cerebral cortex. Brain Res Bull. 1984;12(3):221-6.

Small DM. Central gustatory processing in humans. Adv Otorhinolaryngol. 2006;63:191-220.

Smith DV, Li CS, Davis BJ. Excitatory and inhibitory modulation of taste responses in the hamster brainstem. Ann $N$ Y Acad Sci. 1998;855:450-6. 
Song Q, Lange T, Spahr A, Adler G, Bode G. J. Characteristic distribution pattern of Helicobacter pylori in dental plaque and saliva detected with nested PCR. J Med Microbiol. 2000;49:349-53.

Spector AC. The functional consequences of gustatory nerve regeneration as assessed behaviorally in a rat model. Chemical Senses 2005;30(1):i66-7.

St John SJ, Smith DV. Neural representation of salts in the rat solitary nucleus: brain stem correlates of taste discrimination. $J$ neurophysiol. 2000;84(2): 628-38.

Stewart WF, Ricci JA, Chee E, Hirsch AG, Brandeburg NA. Lost productive time and costs due to diabetes and diabetic neuropathic pain in the US workforce. J Occup Environ Med. 2007:49(6):672-9.

Storey AT, Kenny DJ. Growth, development, and aging of orofacial tissues: neural aspects. Adv Dent Res. 1989;3(1):14-29.

Sullivan SL, Ressler KJ, Buck LB. Spatial patterning and information coding in the olfactory system. Curr Opin Genet Dev. 1995;5:516-23.

Talavera K, Yasumatsu K, Yoshida R, Margolskee RF, Voets T, Ninomiya $Y$, Nilius B. The taste transduction channel TRPM5 is a locus for bitter-sweet taste interactions. The FASEB J. 2008;22:1343-55.

Talbot JD, Marrett S, Evans AC, Meyer E, Buchnell MC, Duncan GH. Multiple representations of pain in human cerebral córtex. Science. $1991 ; 251: 1355-8$.

Talbot WH, Darian-Smith I, Kornhuber HH, Mountcastle VB. The sense of flutter-vibration: comparison of the human capacity with response patterns of mechanoreceptive afferents from the monkey hand. $J$ neurophysiol. 1968; 31:301-34. 
Tannenbaum AS. The sense of consciousness. $J$ Theor Biol. $2001 ; 211(4): 377-91$.

Tanner WP Jr, Swets JA. A decision-making theory of visual detection. Psychol Rev. 1954;61:401-9.

Teixeira MJ. A lesão por radiofrequência e a descompressão neurovascular para 0 tratamento da neuralgia do trigêmeo [Dissertação]. São Paulo: Faculdade de Medicina, Universidade de São Paulo; 1984.

Teixeira MJ. A lesão do trato de Lissauer e do corno posterior da medula espinal e a estimulação elétrica do sistema nervoso central para o tratamento da dor por desaferentação [Tese]. São Paulo: Faculdade de Medicina, Universidade de São Paulo; 1990.

Teixeira MJ. Conduta em neuralgia do trigêmeo. Condutas em Neurologia, São Paulo: Clínica Neurológica HC/FMUSP, 1991.

Teixeira MJ, Pimenta CAM. Epidemiologia da Dor. In: Teixeira MJ, Correa CF, Pimenta CAM (org). Dor: Conceitos Gerais. São Paulo: Limay; 1994. p. 57-61.

Teixeira MJ. Fisiopatologia da dor. Rev Med. 1995;73(2):55-64.

Teixeira MJ. Tratamento da neuralgia do trigêmeo. In: Pré-Congresso. São Paulo: $4^{\circ}$ Congresso Brasileiro de Neurocirurgia, 1998;18:25-36.

Teixeira MJ, Marcon RM, Rocha RO, Figueiró JB. Epidemiologia clínica da dor. Rev Med. 1999;78:36-54.

Teixeira MJ. Fisiopatologia da Nocicepção e da Supressão da Dor. In: Siqueira JTT, Teixeira MJ, editores. Dor Orofacial. Diagnóstico, Terapêutica e Qualidade de Vida. Curitiba: Maio, 2001. 
Teixeira MJ. Mecanismos de ocorrência de dor. Rev. Med. 2004;83:69113.

Teixeira MJ, Braun- $\mathrm{F}^{\circ} \mathrm{JL}$, Márquez JO, Yeng LT. Dor - Contexto Interdisciplinar. Editora Maio: Paraná, 2003, caps. 1-6-30 e 32.

Teixeira MJ, Okada M. Neuralgia pós-herpética. Rev Med. 1999;78:14049.

Teixeira MJ, Siqueira SRDT, Almeida GM. Percutaneous Radiofrequency Rizhotomy and Neurovascular decompression of the Trigeminal Nerve for the treatment of facial pain. Arq Neuro-Psiquiatr, 2006;64(4):9839.

Ter Horst GJ, Meijler WJ, Korf J, Kemper RH. Trigeminal nociceptioninduced cerebral Fos expression in the conscious rat. Cephalalgia. $2001 ; 21(10): 963-75$.

Thomson WM. Issues in the epidemiological investigation of dry mouth. Gerontology. 2005;22:65-76.

Tibano AT. Alterações hemodinâmicas durante a compressão do gânglio de trigeminal com balão com e sem bloqueio anestésico local. [Tese]. São Paulo; Faculdade de Medicina, Universidade de São Paulo, 2011.

Tinazzi M, Rosso T, Fiaschi A. Role of the somatosensory system in primary dystonia. Mov Disord. 2003;18(6):605-22.

Tomita $\mathrm{H}$, Ikeda $\mathrm{M}$, Okuda $\mathrm{Y}$. Basis and practice of clinical taste examinations. Auris Nasus Larynx. 1986;13(1):S1-15. 
Travers JB, Grill HJ, Norgren R. The effects of glossopharyngeal and chorda tympani nerve cuts on the ingestion and rejection of sapid stimuli: and electromyography analysis in the rat. Behav Brain Res. 1987;25:233-46.

Travers SP, Hu H. Extranuclear projections of rNST neurons expressing gustatory-elicited Fos. J Comp Neurol. 2000;427(1):124-38.

Toda T, Taoka M. Converging patterns of inputs from oral structures in the postcentral somatosensory cortex of conscious macaque monkeys. Exp Brain Res. 2004;158(1):43-9.

Vallbo AB, Hagbarth K-E, Torebjörk HE, Wallin BG. Somatosensory, proprioceptive, and sympathetic activity in human peripheral nerves. Physiol Rev. 1979;59:919-57.

van de Grind W. Physical, neural, and mental timing. Conscious Cogn. 2002;11(2):241-64.

Varraine E, Bonnard M, Pailhous J. Interaction between different sensory cues in the control of human gait. Exp Brain Res. 2002;142(3):374-84.

Vassar R, Chao SK, Sitcheran R, Nunez JM, Vosshall LB, Axel R. Topographic organization of sensory projections to the olfactory bulb. Cell. 1994; 79:981-91.

Vierck CJ, Acosta-Rua AJ, Rossi HL, Neubert JK. Sex differences in thermal pain sensitivity and sympathetic reactivity for two strains of rat. J Pain. 2008;9(8):739-49.

Von Korff M, Dworkin SF, Le Resche L, Kruger A. An epidemiologic comparison of pain complaints. Pain. 1988;32(2):173-83. 
Von Korff M, Dworkin SF, Le Resche L. Graded chronic pain status: an epidemiologic evaluation. Pain. 1990;40(3):279-91.

Wachholtz, Amy B.; Pearce, Michelle J.; Koenig, Harold. - Exploring the Relationship between Spirituality, Coping, and Pain. J Behav Med. 2007; 30:3001-8.

Watkins EA, Wollan PC, Melton LJ, Yawn BP. A population in pain: report from the Olmsted country health study. Pain Med. 2008;9(2):166-74.

Welzl H, D'Adamo P, Lipp HP. Conditioned taste aversion as a learning and memory paradigm. Behav Brain Res. 2001;125:205-13.

World Health Organization. Definition, diagnosis and classification of diabetes mellitus and its complications. Report of a World Health Organization Consultation. WHO/NCD/NCS/99.2. WHO, Geneve. 1999.

Ye Q, Heck GL, DeSimone JA. Effects of voltage perturbation of the lingual receptive field on chorda tympani responses to $\mathrm{Na}+$ and $\mathrm{K}+$ salts in the rat: implications for gustatory transduction. J Gen Physiol. 1994;104(5):885-907.

Zaidi FN, Todd K, Enquist L, Whitehead MC. Types of taste circuits synaptically linked to a few geniculate ganglion neurons. J Comp Neurol. 2008; 511(6):753-72.

Zhu M, Cho YK, Li CS. Activation of delta - opioid receptors reduces excitory input to putative gustatory cells within the nucleus of the solitary tract. J neurophysiol. 2009;101(1):258-68. 


\section{ANEXOS}

\section{Anexo 1}

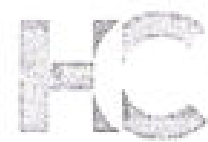

\section{APROVAÇÃO}

A Comissa̋o de Éfica para Análise de Projetos de Pesquisa CAPPesq da Diretoria Clínica do Hospital das Clínicas e da Faculdade de Medicina da Universidade de São Paulo, em sessర̄o de 08/12/2010, APROVOU o Protocolo de Pesquiso $n^{\circ}$ 0751/10, intitulado: "AVAUAÇÃO SENSITIVA QUANTITATIVA DE DOENTES COM DOR OROFACIAL" apresentado pelo Departamento de NEUROLOGIA, inclusive o Termo de Consentimento Livre e Esclarecido.

Cabe ao pesquisador elaborar e apresentar à CAPPesq os relatórios parciois e final sobre a pesquisa (Resolução do Conselho Nacional de Saúde no 196, de 10/10/1996, inciso IX.2, letra "c'7.

Pesquisodior (a) Responsóvel: Prof.Dr. Manoel Jacobsen Telxeira / Profa.Dra. Silvia R.D. Tesseroli de Siqueira

Pesquisador (a) Executante: Profa.Dra. Stlvia Regina Dowgan Tesseroli de Slqueira CAPPesq, 13 de Dezembro de 2010

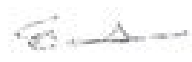

Prof. Dr. Eduardo Massad Presidente da Comissäo de Ética para Análise de Projetos de Pesquisa 


\section{Anexo 2}

Ficha Clínica da Equipe de Dor Orofacial IATM Divisão de Odontologia do Hospital das Clínicas - FMUSP

Nome:

Dentista:

Idade: Tel:

RGHC: Data:

Sexo:

Cor: ( ) B ( ) N( ) Outra:

Estado civil: $\quad O$ paciente está: ( )Só ( )acompanhado por ( )cadeira de rodas

I. ANAMNESE - CARACTERÍSTICAS DA DOR

1- QP (Qual é sua queixa?)

2- Há quanto tempo você tem essa dor?: ()Dias ()Meses ()Anos 3- Periodicidade: ()Diária ()2-3x sem

() Sem ()Quinz ()Mensal.

4- Período do dia que tem dor:()M ()T ()N ()Indiferente 5- Como ela aparece?()Espontânea:()S ()N;

()Provocada: ()N ()S-Como?

()Outro

7-Tipo(característica)da dor: ()Pontada ()Peso ()Queimor ()Choque ()Latejante ()Contínua ()

Outro:

8-Intensidade da dor:()fraca()moderada()forte 9- Nota de 0-10: 10-Essa dor te acorda durante o sono?()N()S

11- Período do dia em que a dor é pior: ()M ()T ()N ()Sono ()Indiferente ()Outro:

13- Sabe o que iniciou a sua dor? ()N ()S - Como?

14- O que piora a sua dor?

15- O que acalma a sua dor?

16- Tratamentos realizados para a dor e melhora (M,PM,SM)

17- Possui o hábito de morder: ()língua ()bochecha ()lábio ()objetos:

18- Você mastiga do lado: ()D ()E ()na frente ()bil (dos 2 lados) 19- Você acha que sua mastigação é: ()boa ()ruim ()péssima ()não sabe ()causa dor - Onde?

2
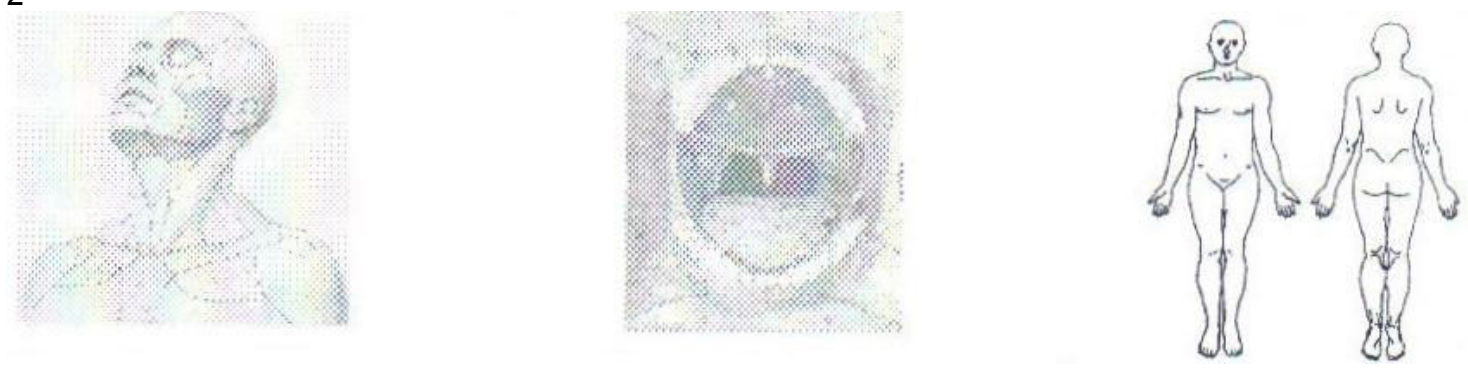

0. Ao acordar sente alguma dor em seu

corpo?()N()S:()rosto()ouvido()cabeça()dentes()pescoço()corpo()Outro

21-Sente o rosto cansado com frequência:()N ()S:()ao acordar()ao mastigar()ao falar()ao sorrir

()outro

22- Sabe se range os dentes: ()à noite ()de dia ()não sabe ()N ()S: Quem disse?

23- Sente ruídos na: ()face ()cabeça ()N ()S - Lado? Quando? ()AB ()fala ()mastiga

( )outro

24- Tem dor provocada por algum movimento da boca?()N ()S-()AB() ()Protrusão ()LaterD ()LaterE ()Outro

25-Tem dor de ouvido?()N()S: Lado?()D ()E Passou pelo médico (ORL)?()N ()S-

$\mathrm{O}$ que ele disse 
26- Tem dor de cabeça? ()N ()S: Onde?

27- Passou pelo médico (Neuro)? ()N ()S-O que ele disse ou receitou?

28- Tem dor no corpo: ()N ()S: Onde?

29- Passou pelo médico? ()N ()S - Qual?

O que ele disse ou receitou?

30- Teve algum acidente, cirurgia ou doença grave? ()N ()S - Qual, como e onde afetou seu corpo?

12- Mostre onde é a sua dor:

()D ()E ()Bilateral; e as dores do seu corpo.

III. ANTECEDENTES MÉDICOS PESSOAIS:

()Artrite reumatóide ()Sinusite

()Fibromialgia ()Coração

()Rinite alérgica

()Herpes zoster (cobreiro)

()Asma

()Parkison

()Bronquite

()Pressão alta (HAS)

()Doença renal (rins)
31- Tratou-se de alguma destas doença:

()Hepatite

()Diabetes

()Depressão

()Amigdalite

()Úlcera

()Infecções
()Outra:

()Derrame (AVC)

()Gastrite

()Enxaqueca

32- Está em tratamento médico atual? Doenças que tem e remédios que usa:

IV. ASPECTOS PSICOLÓGICOS

33- Comportamento durante a consulta:

V. EXAME FÍSICO:

34-Face:()Assimetria facial () Prognatismo ()Laterognatismo - D E Hipertrofia:()Masseter ()Temporal -

()D ()E

35- Pele da Face:

36- Linfonodos:

37- Mucosa oral:

38- Língua

39- Alterações neurológicas:

40- Periodonto:

41- Dentes:

42- Percussão (Vert e Horiz) (0 a 3) 18171615141312112121232425262728

43- Ausências dentárias (/)

44-Interferências oclusais

45- Mordida aberta: ()S ()N

48474645444342413132333435363738

profunda: ()N ()S - ()a ()b ()c

48- Desgates dentários:()N ()S -()Incisais ()1/3 incisal ()1/3 médio ()1/3 cervical 49- Angle: ()Cl I ()Cl II

()Cl III

50- Desdentado Total: ()Sup ()Inf ()Duplo 51- PPR: ()N ()S - Qual:

52- Perda de DV:

()N ()S - _ mm 53- Tempo de uso de PT: _ _ ; 54- Tempo da PT atual: ; 55- Tempo de uso da PPR:

56- Movimentos mandibulares: $\mathbf{A B}$ :_ $\mathrm{mm}$ - ()sem dor - ()com dor - local: __ $\mathbf{P}:{ }_{-}^{+} \_\mathrm{mm}-()$ sem dor ()com dor - local __; LD __ mm - ()sem dor ()com dor - local: ___ ; LE:__mm - ()sem dor ()com dor - local

Linha Média: DLMf: mm ()E ()D DLMa: $\mathrm{mm}-() \mathrm{E}() \mathrm{D}$

57- Ruídos na ATM: ()Ausentes ()POP () Crepitação ()D ()E Estalo D - ()IA ()MA ()FA ()IF ()MF ()FF

Estalo E - ()IA ()MA ()FA ()IF ()MF ()FF 
58- Palpação da ATM e dos músculos da mastigação e do pescoço:

\begin{tabular}{|l|l|l|l|}
\hline ATM ou Músculos & Dir & Esq & Obs. \\
\hline ATM -pólo lateral & & & \\
\hline posterior & & & \\
\hline Masseter Inferior & & & \\
\hline Masseter Médio & & & \\
\hline Masseter Superior & & & \\
\hline Masseter Intra-Oral & & & \\
\hline Temporal Anterior & & & \\
\hline Temporal Médio & & & \\
\hline Temporal Posterior & & & \\
\hline Temporal Intra-Oral & & & \\
\hline Digástrico anterior & & & \\
\hline Digástrico posterior & & & \\
\hline ECM superior & & & \\
\hline ECM médio & & & \\
\hline ECM inferior & & & \\
\hline Esplênio cervical & & & \\
\hline Esplênio da cabeça & & & \\
\hline Suboccipitais & & & \\
\hline Trapézio ombro & & & \\
\hline Trapézio pescoço & & & \\
\hline
\end{tabular}

59- Movimentos cervicais dolorosos? ()N ()S - rotação E ()extenção ()flexão obs:

60- Rx, exames ou interconsultas solicitadas:

61- Hipótese Diagnóstica para a dor (CID):

62- Diagnóstico secundário (CID):

63- Diagnóstico final (dor):

64- Tratamento sugerido para a dor: 


\section{Anexo 3}

\section{Questões Xerostomia}

1. O Sr.(a) tem algum problema na sua boca? ()S ()N - No rosto? ()S ()N Qual?

2. Acha sua saliva normal? ()S ()N - Como?

3. Você sente a boca seca? ()S ()N

4. Engole saliva muitas vezes ao dia? ()S ()N

5. Tem dificuldade para engolir saliva? ()S ()N

6. Tem dificuldade para mastigar devido à secura da boca? ()S ()N

7. Tem dificuldade para falar devido à secura de boca?()S ()N

8. Sente o paladar diminuído? ()S ()N

9. Sente a boca seca durante as refeições? ()S ()N

10. Mudou o gosto dos alimentos? ()S ()N Qual?

11. Durante o sono você acorda com sede? ()S ()N

12. Acorda à noite para beber água? ()N ()S

13. Precisa beber líquidos para engolir os alimentos? ()S ()N

14. Evita algum alimento devido à secura da boca? ()S ()N

15. Masca chicletes ou chupa balas para aliviar a sensação de boca seca? ()S ()N

16. Quantos copos de água toma por dia? copos

17. Toma outras bebidas com frequência durante o dia? ()S ()N Qual?

18. Faz uso frequente de: ()Álcool ()Cigarro ()

Outros

19. Sente gosto diferente na boca? ()S ()N

Qual?

20. Tem mau hálito? ()S ()N

21. Sente os olhos secos com frequência? ()S ()N

22. Sente ressecamento na vagina com frequência? ()S ()N

23. Sente ressecamento na pele com frequência? ()S ()N

24. Sente ressecamento no nariz com frequência? ()S ()N

25. Sente o nariz entupido com frequência? ()S ()N

26. Sente queimação frequente na boca? ()S ()N -

27. Onde?

28. Sente secreção na garganta com frequência? ()S ()N

29. Sente dor de garganta com frequência? ()S ()N

30. Usa dentadura? ()S ()N - Dorme com ela? ()S ()N

31. Tem dificuldade para usar a dentadura devido à secura de boca? ()S ()N

32. Sente ardor ou queimação no estômago com frequência? ()S ()N Quantas vezes por semana?

33. Seu intestino funciona normal? ( )S ( )N. Sente ele preso ou solto demais?

34. Você sente que sua digestão é normal? ( )S ( )N. Por quê?

35. Você sente que a digestão de algum alimento é ruim? ( )S ( )N. Qual alimento e por quê? 